Final Report

FWHA/IN/JTRP-2006/5

\title{
ASSESSMENT AND SELECTION OF STORMWATER BEST MANAGEMENT PRACTICES FOR HIGHWAY CONSTRUCTION, RETROFITTING, AND MAINTENANCE
}

\author{
By \\ Lynn A. Corson \\ Director \\ Indiana Clean Manufacturing Technology and \\ Safe Materials Institute \\ School of Civil Engineering \\ Purdue University \\ Joint Transportation Research Program \\ Project No: C-36-78V \\ File No: 4-7-22 \\ SPR-2853 \\ Conducted in Cooperation with the \\ Indiana Department of Transportation \\ and the U.S. Department of Transportation \\ Federal Highway Administration
}

The contents of this report reflect the views of the authors, who are responsible for the facts and the accuracy of the data presented herein. The contents do not necessarily reflect the official views or policies of the Indiana Department of Transportation or the Federal Highway Administration at the time of publication. The report does not constitute a standard, specification, or regulation.

Purdue University

West Lafayette, IN 47907

October 2006 
TECHNICAL REPORT STANDARD TITLE PAGE

\begin{tabular}{|c|c|c|}
\hline $\begin{array}{l}\text { 1. Report No. } \\
\text { FHWA/IN/JTRP-2006/5 }\end{array}$ & 2. Government Accession No. & 3. Recipient's Catalog No. \\
\hline \multirow{2}{*}{\multicolumn{2}{|c|}{$\begin{array}{l}\text { 4. Title and Subtitle } \\
\text { Assessment and Selection of Stormwater Best Management Practices for } \\
\text { Highway Construction, Retrofitting, and Maintenance }\end{array}$}} & $\begin{array}{l}\text { 5. } \quad \text { Report Date } \\
\text { October } 2006\end{array}$ \\
\hline & & 6. Performing Organization Code \\
\hline \multicolumn{2}{|l|}{$\begin{array}{l}\text { 7. Author(s) } \\
\text { Lynn A. Corson }\end{array}$} & $\begin{array}{l}\text { 8. Performing Organization Report No. } \\
\text { FHWA/IN/JTRP-2006/5 }\end{array}$ \\
\hline \multirow{2}{*}{\multicolumn{2}{|c|}{$\begin{array}{l}\text { 9. Performing Organization Name and Address } \\
\text { Joint Transportation Research Program } \\
1284 \text { Civil Engineering Building } \\
\text { Purdue University } \\
\text { West Lafayette, IN 47907-1284 }\end{array}$}} & 10. Work Unit No. \\
\hline & & $\begin{array}{c}\text { 11. Contract or Grant No. } \\
\text { SPR-2853 }\end{array}$ \\
\hline \multirow{2}{*}{\multicolumn{2}{|c|}{$\begin{array}{l}\text { 12. Sponsoring Agency Name and Address } \\
\text { Indiana Department of Transportation } \\
\text { State Office Building } \\
100 \text { North Senate Avenue } \\
\text { Indianapolis, IN } 46204\end{array}$}} & $\begin{array}{c}\text { 13. Type of Report and Period Covered } \\
\text { Final Report }\end{array}$ \\
\hline & & 14. Sponsoring Agency Code \\
\hline \multicolumn{3}{|l|}{ 15. Supplementary Notes } \\
\hline
\end{tabular}

16. Abstract

The objectives of this research were:

1. Research existing data for structural and non-structural BMPs pertaining to the Phase II NPDES Stormwater Construction and Post-Construction Minimum Control Measures. Identify BMPs suitable for use in construction, reconstruction, rehabilitation and retrofitting activities along INDOT roadways and facilties.

2. Give consideration to the Indiana geological and meteorological conditions and the INDOT resources available for maintenance of water quality BMPs.

3. Review documents on the INDOT Publications List and make recommendations regarding potential revisions and/or additions to the documents to adequately address the NPDES Stormwater Program requirements as they pertain to INDOT activities.

17. Key Words

Stormwater, BMPs, MS4s, NPDES, Phase II, storm water controls, specifications, Storm Water Quality Management Plan, SWQMP, NOI, NOT
18. Distribution Statement

No restrictions. This document is available to the public through the National Technical Information Service, Springfield, VA 22161

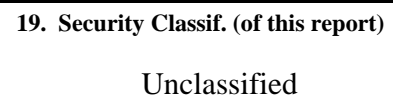

Form DOT F 1700.7 (8-69) 


\title{
Final Report
}

\section{ASSESSMENT AND SELECTION OF STORMWATER BEST MANAGEMENT PRACTICES FOR HIGHWAY CONSTRUCTION, RETROFITTING AND MAINTENANCE}

\author{
CO-Principal Investigators
}

Lynn A. Corson, Ph.D., Director

Indiana Clean Manufacturing Technology and Safe Materials Institute

School of Civil Engineering

and

Christopher B. Burke Engineering, Ltd. (CBBEL)

Joint Transportation Research Program

Project No:

File No:

Indiana SPR 2853

Proposed as an SPR Study in cooperation with INDOT and FHWA

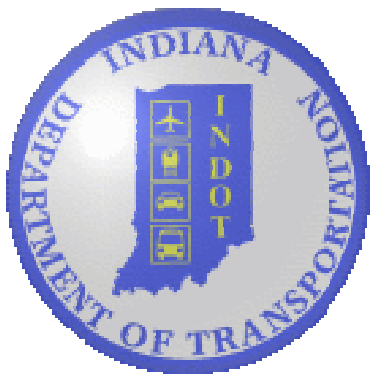

Purdue University

West Lafayette, Indiana
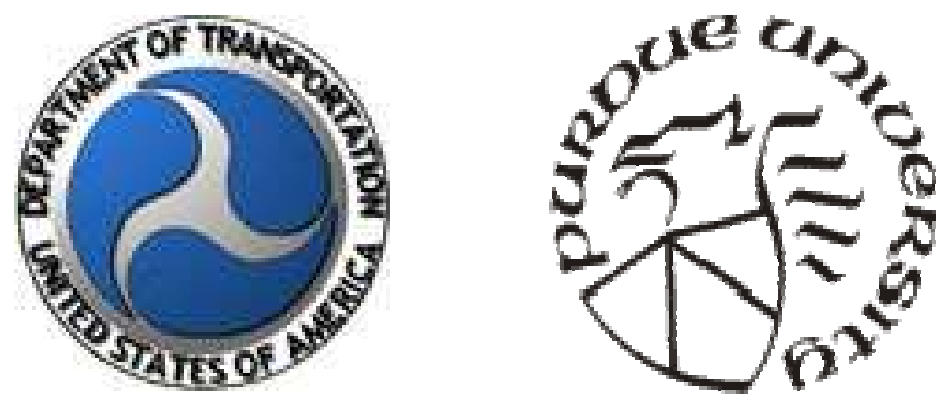

September 2006 
TABLE OF CONTENTS

INTRODUCTION

PROBLEM STATEMENT 2

OBJECTIVE OF PURPOSE

WORK PLAN 3

ANALYSIS OF DATA 3

$\begin{array}{ll}\text { CONCLUSIONS AND RECOMMENDATIONS } & 7\end{array}$

$\begin{array}{ll}\text { IMPLEMENTATION SUGGESTIONS } & 7\end{array}$

APPENDICES

APPENDIX 1 - Database of Research Documents

APPENDIX 2 - Construction and Post-Construction Matrices

APPENDIX 3 - Construction Phase BMP Fact Sheets

APPENDIX 4 - Post-Construction Phase BMP Fact Sheets

APPENDIX 5 - INDOT Documentation Review List

APPENDIX 6 - Construction Activity Environmental Manual Review

APPENDIX 7 - General Instruction to Field Employees Review

APPENDIX 8 - Procedural Manual for Environmental Studies Review

APPENDIX 9 - Suggested Revisions to INDOT Design Manuals, Standard Specifications, Recurring Special Provisions and Standard Drawings

APPENDIX 10 - Suggested Further Research - New Document s 


\section{INTRODUCTION}

Federal and State stormwater regulations require the Indiana Department of Transportation (INDOT) to reduce contaminant loading of stormwater draining from their property or right-of-way in geographic areas designated as Municipal Separate Storm Sewer Systems (MS4s). INDOT must apply for a National Pollutant Discharge Elimination System (NPDES) permit and implement a Storm Water Quality Management Plan (SWQMP) designed to improve the water quality of stormwater runoff. These regulations and the need for INDOT to comply will require revisions to INDOT's standard documents.

A significant aspect of INDOT's compliance will be the removal of pollutants in stormwater runoff from State-maintained roadways. In the past, few types of structural Best Management Practices (BMPs) have been required or designed, constructed, and installed by INDOT for this purpose. Regulatory compliance has dictated this examination of the most appropriate BMPs, based on BMP placement, pollutant removal performance, cost of construction and maintenance.

The contents of this report and section reflect the views of the investigators. The content does not necessarily reflect the official views or policies of INDOT or the Federal Highway Administration (FHWA). The report does not constitute a design procedure, standard, specification, or regulation. This report is independent from INDOT's SWQMP in that INDOT may at their discretion choose to accept, reject, or implement the recommendations contained 
herein and are under no obligation to accept, implement, or pursue any of the recommendations.

\section{PROBLEM STATEMENT}

The Federal and State stormwater regulations will require an improvement in the quality of stormwater runoff from INDOT roadways to waters of the State. Contaminants in roadway drainage can be significantly reduced by implementing appropriate Construction and Post-Construction phase stormwater BMPs and the maintenance of such measures. BMP cost, selection criteria, installation requirements, and maintenance considerations are all factors that need to be addressed.

Analysis and review of pertinent INDOT literature, documents and drawings are necessary in order to recommend changes that will facilitate INDOT compliance with current stormwater regulations and NPDES requirements.

\section{OBJECTIVE AND PURPOSE}

The objectives of this study are:

1. Research existing data for structural and non-structural BMPs pertaining to the Phase II NPDES Stormwater Construction and Post-Construction Minimum Control Measures. Identify BMPs suitable for use in construction, reconstruction, rehabilitation and retrofitting activities, that along INDOT roadways. Consideration will be given to the Indiana 
geological and meteorological conditions and the INDOT resources available for maintenance of such BMPs.

2. Review documents on the INDOT Publications List and make recommendations regarding potential revisions and/or additions to the documents to adequately address the NPDES Stormwater Program requirements as they pertain to INDOT activities.

\section{WORK PLAN}

This project will be completed as two tasks: (1) BMP research, and (2) review of current INDOT documentation.

TASK 1: BMP research will include review of data for structural and nonstructural BMPs pertaining to the Phase II NPDES Stormwater MS4 Construction and Post-Construction Minimum Control Measures. This task of the research will be conducted by reviewing relevant resources from the FHWA and State Departments of Transportation (DOTs), State and regional BMP manuals, general stormwater articles and websites, independent studies and other related industry centers that are pertinent to Indiana's geological, environmental, and meteorological conditions. BMPs that could be applied to INDOT activities will be identified. Selection criteria for these BMPs, including published data on the effectiveness, cost, installation, and maintenance requirements will be organized into an evaluation matrix. Matrix information, along with a description of the specific BMP advantages and disadvantages, will be summarized in individual fact sheets. 
TASK 2: Review of current INDOT documentation. The purpose of this review will be to make recommendations regarding potential revisions and/or additions to the INDOT standard documents that would be needed to adequately address Phase II NPDES Stormwater Program requirements. Recommendations will primarily be organized by the document reviewed, or according to the specific Construction or Post-Construction phase BMPs identified under Task 1. Additional non-existing documents, programs, or certification courses will be recommended for development by INDOT to facilitate compliance with current stormwater regulations and NPDES requirements.

\section{ANALYSIS OF DATA}

After reviewing numerous articles, books, presentations, and design manuals, only those that focused primarily on BMP design, construction, selection, relative effectiveness, or relative cost were evaluated further and entered into a database. The database divided the studies and reports into three categories:

1. General Stormwater BMP Studies and Reports - These studies were typically sponsored by universities or other research groups and were not necessarily specific to highway construction, retrofitting, or maintenance projects.

2. Department of Transportation Manuals -These manuals were developed by other DOTs and their consulting engineers and were typically developed to assist DOTs and their contractors with 
complying with local, State, or Federal stormwater management regulations. These documents often included design and construction specifications and BMP selection criteria and guidance.

3. State/Regional Stormwater Manuals - These manuals were typically developed by State or regional organizations as guidance manuals to help municipalities, the development community, and other various entities comply with stormwater regulations. BMP applications identified in these manuals were not necessarily specific to DOT applications. These documents often included design and construction specifications and BMP selection criteria.

Each database citation includes background data such as title, sub-title, authors, publication date, source, document type, publication number, link, format, types of BMPs, depth of information, nature of information, level of detail, apparent applicability to cold climate, BMP selection criteria, cost and maintenance considerations, description, and notes. Details can be found in Appendix 1.

Based on the BMP material studied, engineering expertise and a Study Advisory Committee, a list of Construction and Post-Construction BMPs typical of INDOT construction, retrofitting, and maintenance projects was compiled into two matrices which can be found in Appendix 2. The Construction BMP Selection Matrix allows a user to quickly compare and select the most appropriate BMP based on installation, maintenance, water quantity rate control benefit, and water quality benefit. 
In consideration of the types of projects that INDOT typically undertakes, BMPs were classified into linear and non-linear applications. Linear projects are those whose right-of-way is generally at or below standard clear zone requirements. Non-linear projects are those that require additional right-of-way to incorporate additional features (e.g. interchanges, rest stops, maintenance facilities). Linear and non-linear stormwater BMPs used during the Construction phase are further categorized by whether the water quality practice relies on the mechanism of erosion control or sediment control. The Post-Construction BMP Selection Matrix is a 3-step filtering process used to determine the most appropriate BMP, or group of BMPs to address Stormwater runoff. Step 1 addresses physical feasibility factors and allows the designer to determine whether development site conditions such as area requirements, soils, terrain, depth to water table, drainage area, head, or whether the site is ultra-urban. Those BMPs that are not eliminated in Step 1 are considered in Step 2, stormwater treatment suitability. Each remaining BMP is rated based on its effectiveness to provide water quantity and water quality benefits. BMPs that remain after Step 2 are considered in Step 3. This final step considers community and environmental factors including construction costs, maintenance, community acceptance and benefit for wildlife habitat.

A BMP fact sheet was developed for each Construction and PostConstruction BMP identified. The fact sheets are intended to provide more detailed information about each BMP. Each Construction Phase BMP fact sheet includes quick reference bullet points that identify when to use, advantages, 
limitations, installation cost, maintenance effort, runoff rate and volume control. Similarly, the Post-Construction BMP fact sheets include quick reference bullet points that identify when to use, advantages, limitations, percent pollutant removal, runoff volume and rate control, annual maintenance cost, relative construction cost and effective life. Construction BMP fact sheets can be found in Appendix 3 and Post-Construction BMP fact sheets can be found in

\section{Appendix 4.}

The review of INDOT documentation portion of the project included review of forty-five INDOT documents related to the design, construction, and maintenance of INDOT roadways. A listing of all the documents reviewed can be found in Appendix 5. Recommended changes and additions that INDOT may decide to accept, reject or implement are included for the following documents in the appendices as noted:

- Appendix 6 - Construction Activity Environmental Manual (CAEM)

- Appendix 7 - General Instruction to Field Employees (GIFE),

- Appendix 8 - Procedural Manual for Environmental Studies (PMES),

Recommendations to be accepted rejected or implemented for the following documents are in Appendix 9

- INDOT Design Manuals (all)

- INDOT Standard Specifications

- INDOT Recurring Special Provisions

- INDOT Standard Drawings

Due to the integrated nature of the above four categories of document, and for the ease of adoption or rejection, suggested revisions to these documents are organized by specific BMP measure, rather than by document. Such suggested 
revisions are provided in Appendix 9. In this way, the respective Construction Phase and Post-Construction Phase BMP measures may be adopted or rejected by INDOT without affecting the remainder of the suggested revisions. In some instances this has resulted in duplication of recommended changes to specific sections. However, this approach provides INDOT with the maximum flexibility with regards to acceptance or exclusion of individual measures without major modification to the remainder of the suggestions.

\section{CONCLUSIONS AND RECOMMENDATIONS}

This report presents the results of analysis and review of comprehensive INDOT literature, documents and drawings, and the subsequent suggested revisions necessary to facilitate INDOT compliance with NPDES requirements. Recommendations for changes to the CAEM, GIFE and PMES documents are provided in Appendices 6,7 and 8, respectively. Because of the integrated nature of the INDOT Design Manuals, Standard Specifications, Recurring Special Provisions and Standard Drawings, suggested revisions were provided on a BMP measure-by-measure basis. These suggestions are provided in Appendix 9. Several new documents specific to the goals and directive of this study are suggested for further research. These new perceived document needs are outlined in Appendix 10.

\section{IMPLEMENTATION SUGGESTIONS}


The appropriate committees within INDOT should review the suggested revisions to water quality practices available to designers and consultants, presented in the matrices of Appendix 2. Concise fact sheets of such measures are provided for Construction and Post-Construction phases of facility operations in Appendices 3 and 4, respectively. Suggested revisions to the CAEM, GIFE and PMES documents are provided in Appendices 6,7 and 8. The most prominent change to the engineering community would be the implementation of suggested changes to INDOT Design Manuals, Standard Specifications, Recurring Special Provisions and Standard Drawings, presented in Appendix 9. Upon acceptance or rejection by INDOT of suggested revisions outlined herein, it is further suggested that INDOT coordinate with IDEM for concurrence on full compliance with outstanding NPDES requirements. Appendix 10 outlines some areas of further research that would be useful to INDOT as they seek implementation of their SWQMP and should help streamline incorporation of improved water quality practices into the INDOT planning, design and construction processes. 
APPENDIX 1

DATABASE OF RESEARCH DOCUMENTS 


\section{GENERAL STORMWATER BMP STUDIES AND REPORTS}




\section{Center for Research in Water Resources}

\begin{tabular}{|l|l|}
\hline Title: & $\begin{array}{l}\text { A Review and Evaluation of Literature } \\
\text { Pertaining to the Quantity and Control of } \\
\text { Pollution from Highway Runoff and } \\
\text { Construction }\end{array}$ \\
\hline Sub Title: & \\
\hline Authors: & $\begin{array}{l}\text { Michael E. Barrett, M.S., Robert D. Zuber, } \\
\text { M.S., E.R. Collins, Ill, M.S., Joseph F. Malina, } \\
\text { Jr. P.E., Randall J. Charbeneau, P.E., and } \\
\text { George H. Ward, Ph.D. }\end{array}$ \\
\hline Publication Date: & April 1993 \\
\hline Source: & $\begin{array}{l}\text { Center for Research in Water Resources. } \\
\text { The University of Texas. }\end{array}$ \\
\hline Document Type: & University Study (Technical Report) \\
\hline Publication \#: & N/A \\
\hline Link: & N/A \\
\hline Format: & Hard Copy \\
\hline Types of BMPs: & $\begin{array}{l}\text { Prevention: } \\
\text { Stormwater: Ponds, Wetlands, Infiltration, } \\
\text { Filters } \\
\text { Sediment: }\end{array}$ \\
\hline Depth of Information: & Comprehensive \\
\hline Nature of Information: & Conceptual \\
\hline Level of Detail: & High \\
\hline Applicability to Cold Climate: & Limited \\
\hline BMP Selection Criteria: & No \\
\hline Cost and Maintenance Considerations: & $\begin{array}{l}\text { Relative/General discussions on cost/ } \\
\text { maintenance. }\end{array}$ \\
\hline Description: & $\begin{array}{l}\text { This document summarizes a review of } \\
\text { previous research into the quality of } \\
\text { stormwater runoff, the environmental impacts } \\
\text { of highway construction and operation, and } \\
\text { feasible mitigation strategies to control } \\
\text { negative impacts of runoff. }\end{array}$ \\
\hline Notes: & \\
\hline & \\
\hline & \\
\hline & \\
\hline &
\end{tabular}




\section{National Cooperative Highway Research Program}

\begin{tabular}{|c|c|}
\hline Title: & $\begin{array}{l}\text { Best Management Practices for } \\
\text { Environmental Issues Related to Highway } \\
\text { and Street Maintenance }\end{array}$ \\
\hline Sub Title: & A Synthesis of Highway Practice \\
\hline Authors: & William A. Hyman and Donald Vary \\
\hline Publication Date: & 1999 \\
\hline Source: & NCHRP \\
\hline Document Type: & General Environmental \\
\hline Publication \#: & $\mathrm{N} / \mathrm{A}$ \\
\hline Link: & $\begin{array}{l}\text { http://ntl.bts.gov/lib/21000/21800/21818/PB99 } \\
\text { 143489.pdf }\end{array}$ \\
\hline Format: & $\overline{\text { Hard Copy (PDF) }}$ \\
\hline Types of BMPs: & $\begin{array}{l}\text { Prevention: } \\
\text { Stormwater: } \\
\text { Sediment: }\end{array}$ \\
\hline Depth of Information: & General \\
\hline Nature of Information: & Conceptual \\
\hline Level of Detail: & Moderate \\
\hline Applicability to Cold Climate: & Yes \\
\hline BMP Selection Criteria: & No \\
\hline Cost and Maintenance Considerations: & General discussions. \\
\hline Description: & $\begin{array}{l}\text { The report describes a variety of BMPs } \\
\text { related to road and street maintenance. } \\
\text { Includes a summary of literature research on } \\
\text { BMPs and a survey of federal, state, and local } \\
\text { transportation agencies. }\end{array}$ \\
\hline Notes: & \\
\hline
\end{tabular}




\section{Metropolitan Seattle Water Pollution Control Department}

\begin{tabular}{|l|l|}
\hline Title: & $\begin{array}{l}\text { Biofiltration Swale Performance, } \\
\text { Recommendations, and Design } \\
\text { Considerations }\end{array}$ \\
\hline Sub Title: & \\
\hline Authors: & $\begin{array}{l}\text { Zahid Khan, Cindy Thrush, Phil Cohen, } \\
\text { Louise Kulzer, Robert Franklin, Del Field, } \\
\text { John Koon, Richard Horner }\end{array}$ \\
\hline Publication Date: & October 5, 1992 \\
\hline Source: & N/A \\
\hline Document Type: & Biofiltration Swales Performance and Design \\
\hline Publication \#: & N/A \\
\hline Link: & N/A \\
\hline Format: & Hard Copy \\
\hline Types of BMPs: & $\begin{array}{l}\text { Prevention: } \\
\text { Stormwater: Biofiltration } \\
\text { Sediment: }\end{array}$ \\
\hline Depth of Information: & Comprehensive \\
\hline Nature of Information: & Comprehensive \\
\hline Level of Detail: & High \\
\hline Applicability to Cold Climate: & Somewhat \\
\hline BMP Selection Criteria: & No \\
\hline Cost and Maintenance Considerations: & $\begin{array}{l}\text { Limited discussions on costs. } \\
\text { General discussions on maintenance. }\end{array}$ \\
\hline Description: & $\begin{array}{l}\text { The study evaluates the pollutant removal } \\
\text { efficiency of grassy swales of differing } \\
\text { lengths. }\end{array}$ \\
\hline Notes: & \\
\hline
\end{tabular}




\section{Center for Research in Water Quality}

\begin{tabular}{|c|c|}
\hline Title: & $\begin{array}{l}\text { Evaluation of The Performance Of Permanent } \\
\text { Runoff Controls: Summary and Conclusions }\end{array}$ \\
\hline Sub Title: & $\mathrm{N} / \mathrm{A}$ \\
\hline Authors: & $\begin{array}{l}\text { Barrett, M.E., Keblin, M.V., Walsh, P.M., } \\
\text { Malina, J.F., Jr., and Charbeneau, R.J. }\end{array}$ \\
\hline Publication Date: & November 1997 \\
\hline Source: & Center for Research in Water Resources \\
\hline Document Type: & Permanent Runoff Controls \\
\hline Publication \#: & $\mathrm{N} / \mathrm{A}$ \\
\hline Link: & $\begin{array}{l}\text { http://www.crwr.utexas.edu/reports/1997/rpt9 } \\
\text { 7-3.shtml }\end{array}$ \\
\hline Format: & Digital - pdf \\
\hline Types of BMPs: & $\begin{array}{l}\text { Prevention: } \\
\text { Stormwater: Vegetative Controls and } \\
\text { Filtration Systems } \\
\text { Sediment: }\end{array}$ \\
\hline Depth of Information: & Comprehensive \\
\hline Nature of Information: & Conceptual \\
\hline Level of Detail: & High \\
\hline Applicability to Cold Climate: & Limited \\
\hline BMP Selection Criteria: & No \\
\hline Cost and Maintenance Considerations: & Very Limited \\
\hline Description: & $\begin{array}{l}\text { This study was designed to assist the Texas } \\
\text { Department of Transportation to identify the } \\
\text { types of runoff control systems that are most } \\
\text { applicable to their area. }\end{array}$ \\
\hline Notes: & \\
\hline
\end{tabular}




\section{Federal Highway Administration}

\begin{tabular}{|l|l|}
\hline \hline Title: & $\begin{array}{l}\text { Stormwater Best Management Practices in an } \\
\text { Ultra-Urban Setting: Selection and Monitoring }\end{array}$ \\
\hline Sub Title: & N/A \\
\hline Authors: & Federal Highway Administration \\
\hline Publication Date: & May 2000 \\
\hline Source: & North Carolina DOT \\
\hline Document Type: & Federal Highway Administration \\
\hline Publication \#: & N/A \\
\hline Link: & http://www.fhwa.dot.gov/environment/ultraurb/ \\
\hline index.htm \\
\hline Format: & Hardcopy (PDF) \\
\hline Types of BMPs: & $\begin{array}{l}\text { Prevention: } \\
\text { Stormwater: Ultra Urban } \\
\text { Sediment: }\end{array}$ \\
\hline Depth of Information: & Comprehensive \\
\hline Nature of Information: & Comprehensive \\
\hline Level of Detail: & High \\
\hline Applicability to Cold Climate: & Somewhat \\
\hline BMP Selection Criteria: & Yes \\
\hline Cost and Maintenance Considerations & Relative capital and O\&M Costs \\
\hline Description: & $\begin{array}{l}\text { The purpose of this document is to provide a } \\
\text { planning level review of applicability and use } \\
\text { of new and more traditional BMPs in ultra } \\
\text { urban areas. }\end{array}$ \\
\hline Not considered a design manual. \\
\hline Notes: & \\
\hline
\end{tabular}




\section{University of Washington Department of Civil Engineering Services}

\begin{tabular}{|l|l|}
\hline Title: & $\begin{array}{l}\text { Technology Review: Ultra Urban Stormwater } \\
\text { Treatment Technologies }\end{array}$ \\
\hline Sub Title: & \\
\hline Authors: & Brueske, Christopher C. \\
\hline Publication Date: & September 2000 \\
\hline Source: & University of Washington \\
\hline Document Type: & Ultra Urban \\
\hline Publication \#: & N/A \\
\hline Link: & N/A \\
\hline Format: & Hard Copy \\
\hline Types of BMPs: & $\begin{array}{l}\text { Prevention: } \\
\text { Stormwater: In line BMPs (Gravity, Swirl } \\
\text { concentration, Screening) } \\
\text { Sediment: }\end{array}$ \\
\hline Depth of Information: & Comprehensive \\
\hline Nature of Information: & Conceptual/ Design \\
\hline Level of Detail: & High \\
\hline Applicability to Cold Climate: & Somewhat \\
\hline BMP Selection Criteria: & No \\
\hline Cost and Maintenance Considerations: & Very Limited \\
\hline Description: & $\begin{array}{l}\text { This study was designed to provide a review } \\
\text { of Ultra-Urban Stormwater Treatment } \\
\text { Technologies. Summarizes hydraulic } \\
\text { principles of each BMP and summarizes a } \\
\text { review of literature on performance data. }\end{array}$ \\
\hline Notes: & I \\
\hline
\end{tabular}




\section{Virginia Transportation Research Council}

\begin{tabular}{|l|l|}
\hline Title: & $\begin{array}{l}\text { Testing of Ultra-Urban Stormwater Best } \\
\text { Management Practices }\end{array}$ \\
\hline Sub Title: & \\
\hline Authors: & Yu, Shaw L., Stopinski D. Monika \\
\hline Publication Date: & January 2001 \\
\hline Source: & Virginia Transportation Research Council \\
\hline Document Type: & Ultra Urban \\
\hline Publication \#: & N/A \\
\hline Link: & http://www.virginiadot.org/vtrc/main/online re \\
\hline ports/pdf/01-r7.pdf \\
\hline Format: & Hard Copy (PDF) \\
\hline Types of BMPs: & $\begin{array}{l}\text { Prevention: } \\
\text { Stormwater: Ultra Urban } \\
\text { Sediment: }\end{array}$ \\
\hline Depth of Information: & Comprehensive \\
\hline Nature of Information: & Conceptual/ Experimental \\
\hline Level of Detail: & High \\
\hline Applicability to Cold Climate: & Somewhat \\
\hline BMP Selection Criteria: & No \\
\hline Cost and Maintenance Considerations: & $\begin{array}{l}\text { Compares capital and O\&M costs of four } \\
\text { ultra-urban BMPs. }\end{array}$ \\
\hline Description: & $\begin{array}{l}\text { This study was designed to evaluate the use } \\
\text { of Ultra Urban BMPs in Virginia as innovative } \\
\text { stormwater control technologies for } \\
\text { application to highway nonpoint source } \\
\text { pollution. }\end{array}$ \\
\hline Notes: & I \\
\hline
\end{tabular}


Center for Research in Water Resources

\begin{tabular}{|l|l|}
\hline Title: & $\begin{array}{l}\text { Water Quality and Quantity Impacts of } \\
\text { Highway Construction and Operation: } \\
\text { Summary and Conclusions }\end{array}$ \\
\hline Sub Title: & N/A \\
\hline Authors: & $\begin{array}{l}\text { Barrett, Michael E., Malina, Joseph E., } \\
\text { Charbeneau, Randall J., Ward, George H. }\end{array}$ \\
\hline Publication Date: & November 2001 \\
\hline Source: & Center for Research in Water Resources \\
\hline Document Type: & Highway Runoff Quality and Quantity \\
\hline Publication \#: & N/A \\
\hline Link: & N/A \\
\hline Format: & Hard Copy \\
\hline Types of BMPs: & $\begin{array}{l}\text { Prevention: } \\
\text { Stormwater: Grass Swales and Sand Filters } \\
\text { Sediment: Rock Berms, Silt Fences }\end{array}$ \\
\hline Depth of Information: & Moderate \\
\hline Nature of Information: & Experimental \\
\hline Level of Detail: & Moderate \\
\hline Applicability to Cold Climate: & Limited \\
\hline BMP Selection Criteria: & No \\
\hline Cost and Maintenance Considerations: & Very Limited \\
\hline Description: & $\begin{array}{l}\text { This study was designed to evaluate the } \\
\text { effects of highway runoff on the quality of } \\
\text { receiving waters. }\end{array}$ \\
\hline Notes: & \\
\hline
\end{tabular}




\section{DEPARTMENT OF TRANSPORTATION MANUALS}


North Carolina Department of Transportation

\begin{tabular}{|c|c|}
\hline Title: & $\begin{array}{l}\text { Best Management Practices for Construction } \\
\text { and Maintenance Activities }\end{array}$ \\
\hline Sub Title: & $\mathrm{N} / \mathrm{A}$ \\
\hline Authors: & North Carolina DOT \\
\hline Publication Date: & August 2003 \\
\hline Source: & North Carolina DOT \\
\hline Document Type: & Construction and Maintenance BMPs \\
\hline Publication \#: & $\mathrm{N} / \mathrm{A}$ \\
\hline Link: & $\begin{array}{l}\text { http://www.doh.dot.state.nc.us/operations/BM } \\
\text { P Manual/download/BMP Manual.pdf }\end{array}$ \\
\hline Format: & Hardcopy (PDF) \\
\hline Types of BMPs: & $\begin{array}{l}\text { Prevention: } \\
\text { Stormwater: } \\
\text { Sediment: Check Dams, Impervious Dikes, } \\
\text { Temporary Seeding. }\end{array}$ \\
\hline Depth of Information: & Comprehensive \\
\hline Nature of Information: & Conceptual \\
\hline Level of Detail: & High \\
\hline Applicability to Cold Climate: & Limited \\
\hline BMP Selection Criteria: & No \\
\hline Cost and Maintenance Considerations: & $\begin{array}{l}\text { Limited discussions on cost. } \\
\text { General discussions on maintenance. }\end{array}$ \\
\hline Description: & $\begin{array}{l}\text { The Manual is designed for employees and } \\
\text { contractors to construct, and maintain the } \\
\text { NCDOT roadway systems while minimizing } \\
\text { adverse impacts on the water resources of } \\
\text { the State. The manual discusses BMPs that } \\
\text { should be used for both general and specific } \\
\text { DOT projects, and then discusses specifics } \\
\text { including design and installation guidance for } \\
\text { construction site BMPs. }\end{array}$ \\
\hline Notes: & \\
\hline
\end{tabular}




\section{Maine Department of Transportation}

\begin{tabular}{|l|l|}
\hline Title: & $\begin{array}{l}\text { Best Management Practices for Erosion \& } \\
\text { Sediment Control }\end{array}$ \\
\hline Sub Title: & N/A \\
\hline Authors: & Maine Department of Transportation \\
\hline Publication Date: & September 2002 \\
\hline Source: & Maine Department of Transportation \\
\hline Document Type: & PDF (Hard Copy) \\
\hline Publication \#: & N/A \\
\hline Link: & http://www.maine.gov/mdot/contractor- \\
& consultant-information/bmprevision90602.pdf \\
\hline Format: & Hard Copy (PDF) \\
\hline Types of BMPs: & $\begin{array}{l}\text { Prevention: } \\
\text { Stormwater: } \\
\text { Sediment: Check Dams/ Mulching/ Seeding/ } \\
\text { etc. }\end{array}$ \\
\hline Depth of Information: & Moderate \\
\hline Nature of Information: & Conceptual/Design \\
\hline Level of Detail: & Moderate \\
\hline Applicability to Cold Climate: & Applicable \\
\hline BMP Selection Criteria: & Limited Guidance \\
\hline Cost and Maintenance Considerations: & $\begin{array}{l}\text { Limited to no discussion of cost. } \\
\text { General discussion on maintenance for each } \\
\text { BMP. }\end{array}$ \\
\hline Description: & $\begin{array}{l}\text { Provides a variety of information on } \\
\text { temporary erosion and sediment control } \\
\text { BMPs. Discussions on each BMP include " } \\
\text { What is it, When and where to use it, What to } \\
\text { consider, Maintenance/performance." Is not a } \\
\text { specification document. However, design } \\
\text { considerations are listed when appropriate. } \\
\text { Not a comprehensive Stormwater Manual. }\end{array}$ \\
\hline Notes: & \begin{tabular}{l} 
(i) \\
\hline
\end{tabular} \\
\hline
\end{tabular}




\section{Virginia Transportation Research Council}

\begin{tabular}{|l|l|}
\hline Title: & $\begin{array}{l}\text { Development of A Stormwater Best } \\
\text { Management Practice Placement Strategy for } \\
\text { the VDOT }\end{array}$ \\
\hline Sub Title: & N/A \\
\hline Authors: & Yu, Shaw L., Stopinski D. Monika \\
\hline Publication Date: & October 2003 \\
\hline Source: & Virginia Transportation Research Council \\
\hline Document Type: & Post-Construction BMP Placement \\
\hline Publication \#: & N/A \\
\hline Link: & $\begin{array}{l}\text { http://www.virginiadot.org/vtrc/main/online re } \\
\text { ports/pdf/04-cr9.pdf }\end{array}$ \\
\hline Format: & Electronic (PDF) \\
\hline Types of BMPs: & $\begin{array}{l}\text { Prevention: } \\
\text { Stormwater: Ponds and Post-Construction } \\
\text { Sediment: }\end{array}$ \\
\hline Depth of Information: & Moderate \\
\hline Nature of Information: & Experimental \\
\hline Level of Detail: & Moderate \\
\hline Applicability to Cold Climate: & Limited \\
\hline BMP Selection Criteria: & No \\
\hline Cost and Maintenance Considerations: & $\begin{array}{l}\text { Calculates cost effectiveness of various } \\
\text { BMPs. }\end{array}$ \\
\hline Description: & $\begin{array}{l}\text { The goal of this study was to develop an } \\
\text { approach to determine the optimal placement } \\
\text { of the BMPs so that the combined affects of } \\
\text { the BMPs will provide the most cost effective } \\
\text { way of treating stormwater from highways and } \\
\text { other sources. }\end{array}$ \\
\hline $\begin{array}{l}\text { Not very useful for BMP selection or design } \\
\text { guidance. }\end{array}$ \\
\hline Notes: & \\
\hline
\end{tabular}




\begin{tabular}{|c|c|}
\hline Title: & Highway Runoff Manual \\
\hline \multicolumn{2}{|l|}{ Sub Title: } \\
\hline Authors: & Washington State Dept of Transportation \\
\hline Publication Date: & March 2004 \\
\hline Source: & $\begin{array}{l}\text { Environmental and Engineering Service } \\
\text { Center }\end{array}$ \\
\hline Document Type: & General Stormwater and BMP Manual \\
\hline Publication \#: & M $31-16$ \\
\hline Link: & $\begin{array}{l}\text { http://www.wsdot.wa.gov/fasc/EngineeringPu } \\
\text { blications/Manuals/HighwayRunoff.pdf }\end{array}$ \\
\hline Format: & Digital - pdf \\
\hline Types of BMPs: & $\begin{array}{l}\text { Prevention: None } \\
\text { Stormwater: Detention / Retention / } \\
\text { Sediment: Construction / Soil Erosion }\end{array}$ \\
\hline Depth of Information: & Comprehensive \\
\hline Nature of Information: & Conceptual / Design \\
\hline Level of Detail: & High \\
\hline Applicability to Cold Climate: & Somewhat Applicable \\
\hline BMP Selection Criteria: & Yes \\
\hline Cost and Maintenance Considerations: & $\begin{array}{l}\text { Estimates cost relative to drainage area. } \\
\text { General Discussions on typical maintenance } \\
\text { requirements. }\end{array}$ \\
\hline Description: & $\begin{array}{l}\text { The Highway Runoff Manual was developed } \\
\text { to direct the planning and design of } \\
\text { stormwater management facilities for existing } \\
\text { and new Washington State highways, rest } \\
\text { areas, park-and-ride lots, ferry terminals, and } \\
\text { highway maintenance facilities throughout the } \\
\text { state. }\end{array}$ \\
\hline Notes: & \\
\hline
\end{tabular}

\footnotetext{
${ }^{1}$ Summary comes directly from the Minnesota Urban Small Sites BMP Manual.
} 
West Virginia Department of Transportation

\begin{tabular}{|l|l|}
\hline Title: & Erosion and Sediment Control Manual \\
\hline Sub Title: & N/A \\
\hline Authors: & $\begin{array}{l}\text { West Virginia Department of Transportation. } \\
\text { Division of Highways. }\end{array}$ \\
\hline Publication Date: & March 2003 \\
\hline Source: & $\begin{array}{l}\text { West Virginia Department of Transportation. } \\
\text { Division of Highways. }\end{array}$ \\
\hline Document Type: & ESC Manual \\
\hline Publication \#: & N/A \\
\hline Link: & $\begin{array}{l}\text { http://www.wvdot.com/engineering/files/EROS } \\
\text { ION/Erosion2003.pdf }\end{array}$ \\
\hline Format: & Web Based \\
\hline Types of BMPs: & $\begin{array}{l}\text { Prevention: None } \\
\text { Stormwater: None } \\
\text { Sediment: Sediment Traps, Temporary } \\
\text { Berms, Diversions, Sediment Basins }\end{array}$ \\
\hline Depth of Information: & Comprehensive \\
\hline Nature of Information: & Conceptual/Design \\
\hline Level of Detail: & Moderate \\
\hline Applicability to Cold Climate: & Applicable \\
\hline BMP Selection Criteria & No \\
\hline Cost and Maintenance Considerations: & Very Limited \\
\hline Description: & $\begin{array}{l}\text { To serve as a guide to WVDOT personnel, } \\
\text { contractors, and consultants involved in the } \\
\text { design, construction and maintenance of } \\
\text { highways, so that they can better perform } \\
\text { individual erosion and sediment control tasks. }\end{array}$ \\
\hline Notes: & \\
\hline
\end{tabular}




\section{Montana Department of Transportation}

\begin{tabular}{|l|l|}
\hline Title: & $\begin{array}{l}\text { Erosion and Sediment Control Best } \\
\text { Management Practices }\end{array}$ \\
\hline Sub Title: & Field and Reference Manuals \\
\hline Authors: & CDM \\
\hline Publication Date: & March 2003 \\
\hline Source: & Montana DOT \\
\hline Document Type: & Construction Site BMPs \\
\hline Publication \#: & N/A \\
\hline Link: & www.mdt.state.mt.us/research/projects/env/er \\
\hline Oormat: & Electronic PDF \\
\hline Types of BMPs: & $\begin{array}{l}\text { Prevention: } \\
\text { Stormwater }\end{array}$ \\
& $\begin{array}{l}\text { Sediment: Soil Stabilization, Temporary } \\
\text { Sediment Controls, Tracking Controls }\end{array}$ \\
\hline Depth of Information: & Comprehensive \\
\hline Nature of Information: & Comprehensive (Construction BMPs) \\
\hline Level of Detail: & High \\
\hline Applicability to Cold Climate: & Yes \\
\hline BMP Selection Criteria: & No \\
\hline Cost and Maintenance Considerations: & $\begin{array}{l}\text { Limited discussions on cost. } \\
\text { General discussions on maintenance. }\end{array}$ \\
\hline Description: & $\begin{array}{l}\text { The purpose of the Manual is to describe the } \\
\text { procedures and methods to reduce erosion } \\
\text { and sedimentation associated with highway } \\
\text { related pre-construction, construction, Post- } \\
\text { Construction activities. Main focus seems to } \\
\text { be on construction activities. }\end{array}$ \\
\hline Notes: & \\
\hline
\end{tabular}




\section{California Department of Transportation (Caltrans)}

\begin{tabular}{|c|c|}
\hline Title: & Stormwater Quality Handbooks \\
\hline Sub Title: & $\begin{array}{l}\text { Construction Site Best Management } \\
\text { Handbooks }\end{array}$ \\
\hline Authors: & $\begin{array}{l}\text { Caltrans. State of California Department of } \\
\text { Transportation. }\end{array}$ \\
\hline Publication Date: & March 2003 \\
\hline Source: & $\begin{array}{l}\text { Caltrans. State of California Department of } \\
\text { Transportation. }\end{array}$ \\
\hline Document Type: & ESC Manual \\
\hline Publication \#: & $\mathrm{N} / \mathrm{A}$ \\
\hline Link: & $\begin{array}{l}\text { http://www.dot.ca.gov/hq/construc/stormwater } \\
\text { /CSBMPM } 303 \text { Final.pdf }\end{array}$ \\
\hline Format: & Hard Copy (PDF) \\
\hline Types of BMPs: & $\begin{array}{l}\text { Prevention: Waste Management, Material } \\
\text { Storage } \\
\text { Stormwater: None } \\
\text { Sediment: Sediment Basins, Traps, and } \\
\text { Barriers, Check Dams, Inlet Protection. }\end{array}$ \\
\hline Depth of Information: & Comprehensive \\
\hline Nature of Information: & Conceptual/Design \\
\hline Level of Detail: & Comprehensive \\
\hline Applicability to Cold Climate: & Applicable \\
\hline BMP Selection Criteria: & Yes, but limited \\
\hline Cost and Maintenance Considerations: & $\begin{array}{l}\text { Detailed cost estimates for Construction } \\
\text { BMPs. Post-Construction BMP estimates } \\
\text { based on cubic meters of water treated. } \\
\text { Limited discussions on BMP Maintenance. }\end{array}$ \\
\hline Description: & $\begin{array}{l}\text { To provide Contractors and Caltrans with } \\
\text { detailed information on design and } \\
\text { implementation of construction site BMPs. }\end{array}$ \\
\hline Notes: & \\
\hline
\end{tabular}


California Department of Transportation (Caltrans)

\begin{tabular}{|l|l|}
\hline Title: & Stormwater Quality Handbooks \\
\hline Sub Title: & Project Planning and Design Guide \\
\hline Authors: & $\begin{array}{l}\text { Caltrans. State of California Department of } \\
\text { Transportation. }\end{array}$ \\
\hline Publication Date: & September 2002 \\
\hline Source: & $\begin{array}{l}\text { Caltrans. State of California Department of } \\
\text { Transportation. }\end{array}$ \\
\hline Document Type: & Planning and Design \\
\hline Publication \#: & N/A \\
\hline Link: & $\begin{array}{l}\text { http://www.dot.ca.gov/hq/construc/stormwater } \\
\text { /CSBMPM 303 Final.pdf }\end{array}$ \\
\hline Format: & Hard Copy (PDF) \\
\hline Types of BMPs: & $\begin{array}{l}\text { Prevention: Waste Management, Material } \\
\text { Storage, Vehicle Fueling } \\
\text { Stormwater: None } \\
\text { Sediment: Sediment Basins, Traps, and } \\
\text { Barriers, Check Dams, Inlet Protection. }\end{array}$ \\
\hline Depth of Information: & Comprehensive \\
\hline Nature of Information: & Conceptual/Design \\
\hline Level of Detail: & Comprehensive \\
\hline Applicability to Cold Climate: & Applicable \\
\hline BMP Selection Criteria: & Yes \\
\hline Cost and Maintenance Considerations: & $\begin{array}{l}\text { Detailed cost estimates for installation, but } \\
\text { limited for maintenance. }\end{array}$ \\
\hline Description: & $\begin{array}{l}\text { To provide design guidance of incorporating } \\
\text { stormwater controls into projects during the } \\
\text { planning and design phase. Detailed } \\
\text { information on selection and BMP design. }\end{array}$ \\
\hline Notes: & \\
\hline
\end{tabular}




\section{STATE \& REGIONAL STORMWATER MANUALS}




\section{Georgia State Manual}

\begin{tabular}{|l|l|}
\hline Title: & Georgia Stormwater Management \\
\hline Sub Title: & Technical Handbook \\
\hline Authors: & $\begin{array}{l}\text { AMEC, Center for Watershed Protection, } \\
\text { Debo and Associates, Jordan, Jones, and } \\
\text { Goulding, Atlanta Regional Commission }\end{array}$ \\
\hline Publication Date: & August 2001 \\
\hline Source: & N/A \\
\hline Document Type: & Post-Construction BMPs \\
\hline Publication \#: & N/A \\
\hline Link: & http://www.georgiastormwater.com \\
\hline Format: & Electronic (PDF) \\
\hline Types of BMPs: & $\begin{array}{l}\text { Prevention: } \\
\text { Stormwater: Ponds, Wetlands, Bio-retention, }\end{array}$ \\
& $\begin{array}{l}\text { sand filters, infiltration, etc } \\
\text { Sediment: }\end{array}$ \\
\hline Depth of Information: & Comprehensive \\
\hline Nature of Information: & Comprehensive/ Design \\
\hline Level of Detail: & High \\
\hline Applicability to Cold Climate: & Limited \\
\hline BMP Selection Criteria: & No \\
\hline Cost and Maintenance Considerations: & $\begin{array}{l}\text { Limited discussion on costs. } \\
\text { General discussion on maintenance. }\end{array}$ \\
\hline Description: & $\begin{array}{l}\text { This study was designed to assist local } \\
\text { governments and developers control the } \\
\text { quality and quantity of downstream waters. } \\
\text { BMP discussions are broken down into } \\
\text { general applicability and limited applicability } \\
\text { discussions. }\end{array}$ \\
\hline Notes: & \\
\hline
\end{tabular}




\begin{tabular}{|c|c|}
\hline \multicolumn{2}{|c|}{ Maryland $^{2}$ State Manual } \\
\hline Title: & Maryland Stormwater Design Manual \\
\hline Sub Title: & $\mathrm{N} / \mathrm{A}$ \\
\hline Authors: & Maryland Department of the Environment \\
\hline Publication Date: & 1998 \\
\hline Source: & Maryland Department of the Environment \\
\hline Document Type: & Digital - pdf \\
\hline Publication \#: & $\mathrm{N} / \mathrm{A}$ \\
\hline Link: & $\begin{array}{l}\text { http://www.mde.state.md.us/environment/wm } \\
\text { a/stormwatermanual/ }\end{array}$ \\
\hline Format: & $\overline{\text { Digital - pdf }}$ \\
\hline Types of BMPs: & $\begin{array}{l}\text { Prevention: Housekeeping / Low Impact } \\
\text { Development / Operations and Maintenance } \\
\text { Stormwater: Detention / Retention / } \\
\text { Infiltration / Filtration / Constructed Wetlands / } \\
\text { Hydraulic Devices } \\
\text { Sediment: Construction / Soil Erosion / } \\
\text { Sediment Control }\end{array}$ \\
\hline Depth of Information: & Comprehensive \\
\hline Nature of Information: & Conceptual / Design \\
\hline Level of Detail: & High \\
\hline Applicability to Cold Climate: & Applicable \\
\hline BMP Selection Criteria: & Yes \\
\hline Cost and Maintenance Considerations: & $\begin{array}{l}\text { Cost (Relative to Drainage Area) } \\
\text { Ease of Maintenance }\end{array}$ \\
\hline Description: & $\begin{array}{l}\text { The manual provides guidance to protect the } \\
\text { waters of the State from adverse impacts of } \\
\text { urban runoff, provides guidance on the most } \\
\text { effective structural and non-structural BMPs } \\
\text { for development sites, and to improve the } \\
\text { quality of BMPs that are constructed in the } \\
\text { State, specifically with regard to performance, } \\
\text { longevity, safety, ease of maintenance, } \\
\text { community acceptance and environmental } \\
\text { benefit. }\end{array}$ \\
\hline Notes: & $\begin{array}{l}\text { Specific design criteria and computations } \\
\text { included. Figure quality varies by BMP. } \\
\text { Comprehensive performance criteria } \\
\text { included. }\end{array}$ \\
\hline
\end{tabular}

\footnotetext{
${ }^{2}$ Summary comes directly from the Minnesota Urban Small Sites BMP Manual. Comments on Selection and cost and Maintenance were developed independently.
} 
Idaho State Manual

\begin{tabular}{|l|l|}
\hline Title: & $\begin{array}{l}\text { Catalog of Stormwater Best Management } \\
\text { Practices }\end{array}$ \\
\hline Sub Title: & For Idaho Cities and Towns \\
\hline Authors: & Idaho Department of Environmental Quality \\
\hline Publication Date: & August 2001 \\
\hline Source: & Idaho Department of Environmental Quality \\
\hline Document Type: & Web-Based (Electronic) \\
\hline Publication \#: & N/A \\
\hline Link: & $\begin{array}{l}\text { www.deq.state.id.us/water/permits forms/per } \\
\text { mitting/catalog bmps.cfm }\end{array}$ \\
\hline Format: & Web Based \\
\hline Types of BMPs: & $\begin{array}{l}\text { Prevention: Spill Prevention/ } \\
\text { Housekeeping/Vehicle and Equipment } \\
\text { Washing } \\
\text { Stormwater: Detention / Retention/ } \\
\text { Infiltration/ } \\
\text { Sediment: Construction/ Soil } \\
\text { Erosion/Sediment Control/Slope Protection }\end{array}$ \\
\hline Comprehensive \\
\hline Depth of Information: & Conceptual \\
\hline Nature of Information: & Moderate \\
\hline Level of Detail: & Applicable \\
\hline Applicability to Cold Climate: & Yes \\
\hline BMP Selection Criteria: & $\begin{array}{l}\text { Limited to no discussion of cost. } \\
\text { General discussion on maintenance. }\end{array}$ \\
\hline Cost and Maintenance Considerations: & $\begin{array}{l}\text { The Catalog of Stormwater BMPs for Idaho } \\
\text { Cities and Counties provides technical } \\
\text { guidance for the selection and site design of } \\
\text { stormwater best management practices } \\
\text { (BMPs). Measures such as those described in } \\
\text { the manual and other recognized equivalents } \\
\text { should be used to manage both the quantity } \\
\text { and quality of stormwater runoff from land } \\
\text { development. }\end{array}$ \\
\hline Description: & \\
\hline Notes: & \\
\hline & \\
& \\
& \\
&
\end{tabular}


University of Virginia

\begin{tabular}{|l|l|}
\hline Title: & $\begin{array}{l}\text { Field Monitoring and Evaluation of } \\
\text { Stormwater Ultra-Urban BMPs }\end{array}$ \\
\hline Sub Title: & N/A \\
\hline Authors: & $\begin{array}{l}\text { Shaw L. Yu, Monika D. Stopinski and Jenny } \\
\text { X. Zhen }\end{array}$ \\
\hline Publication Date: & Late 1990's \\
\hline Source: & University of Virginia \\
\hline Document Type: & Ultra-Urban BMPs \\
\hline Publication \#: & N/A \\
\hline Link: & $\begin{array}{l}\text { http://www.people.virginia.edu/ enqstorm/pdf/ } \\
\text { ultraBMP.pdf }\end{array}$ \\
\hline Format: & Hard Copy (PDF) \\
\hline Types of BMPs: & $\begin{array}{l}\text { Prevention: } \\
\text { Stormwater: Ultra-Urban } \\
\text { Sediment: }\end{array}$ \\
\hline Depth of Information: & Comprehensive \\
\hline Nature of Information: & Experimental/Comparison \\
\hline Level of Detail: & High \\
\hline Applicability to Cold Climate: & Somewhat \\
\hline BMP Selection Criteria: & No \\
\hline Cost and Maintenance Considerations: & $\begin{array}{l}\text { Compares installation and maintenance costs } \\
\text { of four BMPs. }\end{array}$ \\
\hline Description: & $\begin{array}{l}\text { This document summarizes a study of several } \\
\text { Ultra-Urban BMPs over a two year period. } \\
\text { Evaluates a stormceptor, a bioretention area, } \\
\text { and the Vortechs Stormwater treatment } \\
\text { system. The study was sponsored by the } \\
\text { Virginia Department of Transportation. }\end{array}$ \\
\hline Notes: & \begin{tabular}{l} 
\\
\hline
\end{tabular} \\
\hline
\end{tabular}


Reno - Truckee Meadow

\begin{tabular}{|c|c|}
\hline Title: & $\begin{array}{l}\text { Truckee Meadows Construction Site Best } \\
\text { Management Practices }\end{array}$ \\
\hline Sub Title: & $\mathrm{N} / \mathrm{A}$ \\
\hline Authors: & Kennedy/Jenks Consultants \\
\hline Publication Date: & February 2003 \\
\hline Source: & North Carolina DOT \\
\hline Document Type: & Construction Site BMPs \\
\hline Publication \#: & $\mathrm{N} / \mathrm{A}$ \\
\hline Link: & $\begin{array}{l}\text { www.cityofreno.com/gov/pub works/stormwat } \\
\text { er/pdfs/TruckeeMeadowsBMP rev01.pdf }\end{array}$ \\
\hline Format: & Web Based \\
\hline Types of BMPs: & $\begin{array}{l}\text { Prevention: Site and Materials Management } \\
\text { Stormwater: } \\
\text { Sediment: Construction Site BMPs }\end{array}$ \\
\hline Depth of Information: & Comprehensive \\
\hline Nature of Information: & Comprehensive \\
\hline Level of Detail: & High \\
\hline Applicability to Cold Climate: & Limited \\
\hline BMP Selection Criteria: & No \\
\hline Cost and Maintenance Considerations: & $\begin{array}{l}\text { Limited discussions on cost. } \\
\text { General discussion on BMP maintenance. }\end{array}$ \\
\hline Description: & $\begin{array}{l}\text { The primary purpose of the BMP handbook is } \\
\text { to assist local users with the requirements of } \\
\text { NDEP's permit and the local policies } \\
\text { developed in response to the permit } \\
\text { requirements. The intended } \\
\text { users of the handbook include the } \\
\text { owners/operators of construction sites, } \\
\text { developers, design engineers, contractors } \\
\text { and staff from the Cities of Reno and Sparks } \\
\text { and Washoe County. }\end{array}$ \\
\hline Notes: & \\
\hline
\end{tabular}


Tennessee State Manual

\begin{tabular}{|l|l|}
\hline Title: & $\begin{array}{l}\text { Guide to the Selection \& Design of } \\
\text { Stormwater Best Management Practices. }\end{array}$ \\
\hline Sub Title: & $\begin{array}{l}\text { A Guide for Phase Il entities for Protecting } \\
\text { Post-Construction Stormwater Quality and } \\
\text { Managing Stormwater Flow. }\end{array}$ \\
\hline Authors: & $\begin{array}{l}\text { Tennessee Water Resources Research } \\
\text { Center. The University of Tennessee }\end{array}$ \\
\hline Publication Date: & March 2003 \\
\hline Source: & $\begin{array}{l}\text { Tennessee Department of Environment and } \\
\text { Conservation }\end{array}$ \\
\hline Document Type: & Post-Construction \\
\hline Publication \#: & N/A \\
\hline Link: & $\begin{array}{l}\text { http://eerc.ra.utk.edu/divisions/wrrc/BMP/bmp. } \\
\text { htm }\end{array}$ \\
\hline Format: & Hard Copy \\
\hline Types of BMPs: & $\begin{array}{l}\text { Prevention: None } \\
\text { Stormwater: Structural and Nonstructural } \\
\text { Post-Construction BMPs } \\
\text { Sediment: }\end{array}$ \\
\hline Depth of Information: & Comprehensive \\
\hline Nature of Information: & Conceptual/Design \\
\hline Level of Detail: & Comprehensive \\
\hline Applicability to Cold Climate: & Applicable \\
\hline BMP Selection Criteria: & No Matrix but provides guidance. \\
\hline Cost and Maintenance Considerations & $\begin{array}{l}\text { BMPs rated for cost, but non specific. General } \\
\text { discussions and ratings on maintenance. }\end{array}$ \\
\hline Description: & $\begin{array}{l}\text { Provides a variety of information on structural } \\
\text { and nonstructural Post-Construction best } \\
\text { management practices including, Description, } \\
\text { Selection Guidance, Designing and Layout, } \\
\text { Construction, Costs, Limitations for each } \\
\text { BMP. Detailed Exhibits/Figures. }\end{array}$ \\
\hline Notes: & \\
\hline & \\
\hline & \\
\hline & \\
\hline &
\end{tabular}




\begin{tabular}{|l|l|}
\multicolumn{2}{l|}{ Minnesota ${ }^{3}$ State Manual } \\
\hline \hline Title: & Protecting Water Quality in Urban Areas \\
\hline Sub Title: & $\begin{array}{l}\text { Best Management Practices for Dealing with } \\
\text { Storm Water Runoff from Urban, Suburban } \\
\text { and Developing Areas of Minnesota }\end{array}$ \\
\hline Authors: & Minnesota Pollution Control Agency \\
\hline Publication Date: & March 2000 \\
\hline Source: & Minnesota Pollution Control Agency \\
\hline Document Type: & PDF (Hard Copy) \\
\hline Publication \#: & N/A \\
\hline Link: & $\begin{array}{l}\text { http://www.pca.state.mn.us/water/pubs/sw- } \\
\text { bmpmanual.html }\end{array}$ \\
\hline Format: & Web Based \\
\hline Types of BMPs: & $\begin{array}{l}\text { Prevention: Housekeeping/ Low Impact } \\
\text { Development /Operations } \\
\text { Stormwater: Detention / Retention/ } \\
\text { Infiltration/Filtration/ Constructed Wetlands/ } \\
\text { Hydraulic Devices } \\
\text { Sediment: Construction/ Soil } \\
\text { Erosion/Sediment Control }\end{array}$ \\
\hline Depth of Information: & Comprehensive \\
\hline Nature of Information: & Conceptual/Design \\
\hline Level of Detail: & High \\
\hline Applicability to Cold Climate: & Applicable \\
\hline BMP Selection Criteria: & Yes \\
\hline Cost and Maintenance Considerations: & $\begin{array}{l}\text { Limited information on cost. } \\
\text { General discussion on maintenance. }\end{array}$ \\
\hline Description: & $\begin{array}{l}\text { A Comprehensive BMP reference. Content is } \\
\text { largely borrowed from familiar sources. } \\
\text { Provides a good deal of information on } \\
\text { pollution prevention, erosion control, and } \\
\text { sediment control. Some generalized info } \\
\text { regarding the use of proprietary BMPs. No } \\
\text { Design Computations. }\end{array}$ \\
\hline Notes: & \\
\hline
\end{tabular}

${ }^{3}$ Summary comes directly from the Minnesota Urban Small Sites BMP Manual. Comments on Selection and cost and Maintenance were developed independently. 


\section{Northern Virginia Regional Manual}

\begin{tabular}{|c|c|}
\hline Title: & Northern Virginia BMP Handbook. \\
\hline Sub Title: & $\begin{array}{l}\text { A Guide to Planning and Designing Best } \\
\text { Management Practices in N Northern Virginia }\end{array}$ \\
\hline Authors: & $\begin{array}{l}\text { Northern Virginia Planning District } \\
\text { Commission. Engineers and Surveyors } \\
\text { Commission. }\end{array}$ \\
\hline Publication Date: & November 1992 \\
\hline Source: & Maine Department of Transportation \\
\hline Document Type: & PDF (Hard Copy) \\
\hline Publication \#: & $\mathrm{N} / \mathrm{A}$ \\
\hline Link: & $\begin{array}{l}\text { http://www.novaregion.org/pdf/NVBMP- } \\
\text { Handbook.pdf }\end{array}$ \\
\hline Format: & Web Based \\
\hline Types of BMPs: & $\begin{array}{l}\text { Prevention: None } \\
\text { Stormwater: Wet and Dry Ponds, Infiltration } \\
\text { Basins } \\
\text { Sediment: }\end{array}$ \\
\hline Depth of Information: & Moderate \\
\hline Nature of Information: & Conceptual \\
\hline Level of Detail: & Moderate \\
\hline Applicability to Cold Climate: & Applicable \\
\hline BMP Selection Criteria: & Limited Guidance \\
\hline Cost and Maintenance Considerations: & $\begin{array}{l}\text { Information on O\&M costs by BMP type } \\
\text { relative to capital construction costs. } \\
\text { Refers to another study for capital cost of } \\
\text { BMPs. }\end{array}$ \\
\hline Description: & $\begin{array}{l}\text { The Handbook is intended for use by } \\
\text { designers and reviewers of urban BMPs in } \\
\text { meeting the water quality requirements of } \\
\text { Northern Virginia. The Handbook includes } \\
\text { discussion of the theory and practice of } \\
\text { implementing BMP controls, and presents the } \\
\text { requirements set by local jurisdictions for } \\
\text { calculating phosphorus removal as well as for } \\
\text { determining site coverage, storage volume, } \\
\text { and orifice size requirements for BMPs } \\
\text { necessitated by the development of land. }\end{array}$ \\
\hline Note & \\
\hline
\end{tabular}




\section{Los Angeles Regional Manual}

\begin{tabular}{|l|l|}
\hline Title: & $\begin{array}{l}\text { Reference Guide for Stormwater Best } \\
\text { Management Practices }\end{array}$ \\
\hline Sub Title: & N/A \\
\hline Authors: & $\begin{array}{l}\text { City of Los Angeles. Stormwater } \\
\text { Management Division Bureau of Sanitation, } \\
\text { Department of Public Works. }\end{array}$ \\
\hline Publication Date: & July 2000 \\
\hline Source: & $\begin{array}{l}\text { Stormwater Management Division Bureau of } \\
\text { Sanitation, Department of Public Works. }\end{array}$ \\
\hline Document Type: & PDF (Hard Copy) \\
\hline Publication \#: & N/A \\
\hline Link: & $\begin{array}{l}\text { www.lacity.org/SAN/wpd/download/pdfs/publi } \\
\text { cations/bmp refguide.pdf }\end{array}$ \\
\hline Format: & Hard Copy (PDF) \\
\hline Types of BMPs: & $\begin{array}{l}\text { Prevention: Construction Scheduling, } \\
\text { Material Use, Site Maintenance } \\
\text { Stormwater: Vegetative Systems, Infiltration } \\
\text { Sediment: Traps, Basins, Seeding, Barriers }\end{array}$ \\
\hline Depth of Information: & Moderate \\
\hline Nature of Information: & Conceptual/Selection \\
\hline Level of Detail: & Moderate \\
\hline Applicability to Cold Climate: & Somewhat Applicable \\
\hline Cost and Maintenance Considerations: & General cost and maintenance evaluations \\
\hline Description: & $\begin{array}{l}\text { To provide general guidance and information } \\
\text { on stormwater and urban runoff best } \\
\text { management practices. Identify information } \\
\text { on BMPs, assess BMPs, and select BMPs. }\end{array}$ \\
\hline Notes: & \\
\hline
\end{tabular}




\begin{tabular}{|l|l|}
\multicolumn{2}{|c|}{ North Carolina } \\
\hline Title: & State Manual \\
\hline Sub Title: & N/A \\
\hline Authors: & $\begin{array}{l}\text { North Carolina Department of Environment } \\
\text { and Natural Resources - Water Quality }\end{array}$ \\
\hline Publication Date: & April, 1999 \\
\hline Source: & $\begin{array}{l}\text { North Carolina Department of Environment } \\
\text { and Natural Resources - Water Quality }\end{array}$ \\
\hline Document Type: & General Stormwater and BMP Manual \\
\hline Publication \#: & EPA 841-K-94-003 \\
\hline Link: & $\begin{array}{l}\text { http://h2o.enr.state.nc.us/su/documents/BMP } \\
\text { Manual.pdf }\end{array}$ \\
\hline Format: & Web - Based \\
\hline Types of BMPs: & $\begin{array}{l}\text { Prevention: None } \\
\text { Stormwater: Detention / Retention / } \\
\text { Infiltration / Filtration / Constructed Wetlands } \\
\text { Sediment Control: None }\end{array}$ \\
\hline Depth of Information: & Comprehensive \\
\hline Nature of Information: & Conceptual / Design \\
\hline Level of Detail: & High \\
\hline Applicability to Cold Climate: & Applicable \\
\hline BMP Selection Criteria: & No \\
\hline Cost and Maintenance Considerations: & General discussion for most BMPs. \\
\hline Description: & $\begin{array}{l}\text { A concise stormwater BMP reference. This } \\
\text { document is very comprehensive with a } \\
\text { chapter devoted to each of the most } \\
\text { commonly used stormwater treatment BMPs } \\
\text { in North Carolina. An excellent reference. }\end{array}$ \\
\hline Notes: & $\begin{array}{l}\text { Very concise, nice document. Contains } \\
\text { examples of designs and computations for the } \\
\text { application of each BMP. Provides } \\
\text { advantages and disadvantages for each } \\
\text { BMP. Excellent Figures. }\end{array}$ \\
\hline & \\
\hline & \\
\hline &
\end{tabular}

\footnotetext{
${ }^{4}$ Summary comes directly from the Minnesota Urban Small Sites BMP Manual. Comments on Selection and cost and Maintenance were developed independently.
} 
New York State Manual

\begin{tabular}{|l|l|}
\hline Title: & Stormwater Management Design Manual \\
\hline Sub Title: & N/A \\
\hline Authors: & Center for Watershed Protection. \\
\hline Publication Date: & October 2001 \\
\hline Source: & $\begin{array}{l}\text { New York Department of Environmental } \\
\text { Conservation }\end{array}$ \\
\hline Document Type: & PDF (Hard Copy) \\
\hline Publication \#: & N/A \\
\hline Link: & http://www.dec.state.ny.us/website/dow/toolb \\
\hline ox/swmanual/ \\
\hline Format: & Web Based \\
\hline Types of BMPs: & $\begin{array}{l}\text { Pollution Prevention: } \\
\text { Stormwater: } \\
\text { Ponds/Wetlands/Infiltration/Filtering/Open } \\
\text { Channel } \\
\text { Sediment Control: }\end{array}$ \\
\hline Depth of Information: & Comprehensive \\
\hline Nature of Information: & Conceptual/Design \\
\hline Level of Detail: & Comprehensive \\
\hline Applicability to Cold Climate: & Yes \\
\hline BMP Selection Criteria: & Yes \\
\hline Cost and Maintenance Considerations: & $\begin{array}{l}\text { Ease of Maintenance } \\
\text { Cost (Relative to Drainage Area) }\end{array}$ \\
\hline Description: & $\begin{array}{l}\text { To provide designers a general overview on } \\
\text { how to size, design, select and locate BMPs. } \\
\text { The manual contains detailed appendices on } \\
\text { construction specifications and design } \\
\text { examples. The Document also has detailed } \\
\text { guidance on selection and implementation of } \\
\text { Post-Construction practices. }\end{array}$ \\
\hline Notes: & \begin{tabular}{l} 
Con \\
\hline
\end{tabular} \\
\hline
\end{tabular}


Tennessee State Manual

\begin{tabular}{|l|l|}
\hline Title: & $\begin{array}{l}\text { Tennessee Erosion and Sediment Control } \\
\text { Handbook }\end{array}$ \\
\hline Sub Title: & $\begin{array}{l}\text { A guide for protection of State Waters } \\
\text { Through the Use of Best Management } \\
\text { Practices. }\end{array}$ \\
\hline Authors: & John C. Price, Robert Karesh \\
\hline Publication Date: & March 2002 \\
\hline Source: & $\begin{array}{l}\text { Tennessee Department of Environment and } \\
\text { Conservation }\end{array}$ \\
\hline Document Type: & PDF (Hard Copy) \\
\hline Publication \#: & N/A \\
\hline Link: & $\begin{array}{l}\text { http://www.state.tn.us/environment/wpc/sed } \\
\text { ro controlhandbook/ }\end{array}$ \\
\hline Format: & Web Based \\
\hline Types of BMPs: & $\begin{array}{l}\text { Prevention: None } \\
\text { Stormwater: None } \\
\text { Sediment: Sediment Basins, Traps, Barriers, } \\
\text { Check Dams, Inlet Protection. }\end{array}$ \\
\hline Depth of Information: & Comprehensive \\
\hline Nature of Information: & Conceptual/Design \\
\hline Level of Detail: & Comprehensive \\
\hline Applicability to Cold Climate: & Applicable \\
\hline BMP Selection Criteria: & No \\
\hline Cost and Maintenance Considerations: & $\begin{array}{l}\text { Limited discussions on cost. } \\
\text { General maintenance discussions. }\end{array}$ \\
\hline Description: & $\begin{array}{l}\text { Provides a variety of information on BMPs } \\
\text { including, Definition, Purpose, Conditions, } \\
\text { Planning Considerations, Construction } \\
\text { Specifications and Maintenance. }\end{array}$ \\
\hline Notes: & \\
\hline
\end{tabular}




\section{Virginia State Manual}

\begin{tabular}{|l|l|}
\hline Title: & Virginia Stormwater Management Handbook \\
\hline Sub Title: & $\begin{array}{l}\text { A Guide to Planning and Designing Best } \\
\text { Management Practices in Northern Virginia }\end{array}$ \\
\hline Authors: & $\begin{array}{l}\text { Virginia Department of Conservation and } \\
\text { Recreation }\end{array}$ \\
\hline Publication Date: & 1999 \\
\hline Source: & $\begin{array}{l}\text { Virginia Department of Conservation and } \\
\text { Recreation }\end{array}$ \\
\hline Document Type: & PDF (Hard Copy) \\
\hline Publication \#: & N/A \\
\hline Link: & http://www.dcr.state.va.us/sw/stormwat.htm\#h \\
\hline Format: & andbook \\
\hline Types of BMPs: & Web Based \\
& $\begin{array}{l}\text { Prevention: None } \\
\text { Stormwater: Wet and Dry Ponds, Porous }\end{array}$ \\
\hline Pavement, Grassed Swales. \\
Sediment:
\end{tabular}


APPENDIX 2

CONSTRUCTION AND POST-CONSTRUCTION MATRICES 


\section{A. CONSTRUCTION PHASE EROSION CONTROL BMP PRACTICES APPROPRIATE FOR LINEAR and NON-LINEAR} PROJECTS

\begin{tabular}{|c|c|c|c|c|c|c|c|c|c|c|c|}
\hline \multirow{3}{*}{$\begin{array}{l}\text { Suggested } \\
\text { BMPs }\end{array}$} & \multirow{3}{*}{$\begin{array}{l}\text { Fact } \\
\text { Sheet }\end{array}$} & \multirow{3}{*}{$\begin{array}{l}\text { Installation } \\
\text { Cost }\end{array}$} & \multirow{3}{*}{ Maintenance } & \multicolumn{2}{|c|}{$\begin{array}{c}\text { Water Quantity } \\
\text { Benefit }\end{array}$} & \multicolumn{6}{|c|}{ Water Quality Benefit } \\
\hline & & & & \multirow{2}{*}{$\begin{array}{c}\text { Rate } \\
\text { Control }\end{array}$} & \multirow{2}{*}{$\begin{array}{l}\text { Volume } \\
\text { Reduction }\end{array}$} & \multicolumn{2}{|c|}{$\begin{array}{c}\text { Pollution Prevention } \\
\text { Benefit }\end{array}$} & \multicolumn{4}{|c|}{ Pollutant Removal } \\
\hline & & & & & & $\begin{array}{l}\text { Erosion } \\
\text { Control }\end{array}$ & $\begin{array}{l}\text { Sediment } \\
\text { Control }\end{array}$ & TSS & $\mathbf{P} \& \mathbf{N}$ & Metals & $\begin{array}{l}\text { Fecal } \\
\text { Coliform }\end{array}$ \\
\hline Grading & CEC-1 & $\begin{array}{l}\$ 3.50- \\
12.00 / \text { cys }^{(3)}\end{array}$ & Medium & Varies & Varies & Primary & $\mathrm{N} / \mathrm{A}$ & Some & Some & Some & No \\
\hline $\begin{array}{l}\text { Soil } \\
\text { Roughening }\end{array}$ & CEC-2 & $\begin{array}{l}\$ 0.10- \\
\$ 0.50 / \text { sy }\end{array}$ & Low & Some & No & Primary & $\mathrm{N} / \mathrm{A}$ & No & No & No & No \\
\hline Sequencing & CEC-3 & Varies $^{(4)}$ & $\mathrm{N} / \mathrm{A}$ & No & No & Primary & Primary & Some & Some & Some & No \\
\hline $\begin{array}{l}\text { Straw Bale } \\
\text { Ditch Check }\end{array}$ & CEC-4 & $\begin{array}{l}\$ 4.00- \\
\$ 8.00 / \text { /f }\end{array}$ & High & Some & No & Primary & $\mathrm{N} / \mathrm{A}$ & Yes & Some & Some & No \\
\hline $\begin{array}{l}\text { Fiber Wattle } \\
\text { Roll Ditch } \\
\text { Check }\end{array}$ & CEC-5 & $\begin{array}{l}\$ 6.00- \\
\$ 8.00 / \mathrm{lf}\end{array}$ & Medium & Some & No & Primary & $\mathrm{N} / \mathrm{A}$ & Yes & Some & Some & No \\
\hline Straw Mulch & CEC-6 & $\begin{array}{l}\$ 0.20- \\
\$ 0.40 / \text { sy }\end{array}$ & Low & Some & No & Primary & $\mathrm{N} / \mathrm{A}$ & Some & Some & No & No \\
\hline $\begin{array}{l}\text { Bonded Fiber } \\
\text { Matrix (BFM } \\
\text { Mulch) }\end{array}$ & CEC-7 & $\begin{array}{l}\$ 1.50- \\
\$ 2.50 / \mathrm{sy}\end{array}$ & Low & Some & No & Primary & $\mathrm{N} / \mathrm{A}$ & Some & Some & No & No \\
\hline $\begin{array}{l}\text { Erosion } \\
\text { Control } \\
\text { Blanket }\end{array}$ & CEC-8 & $\begin{array}{l}\$ 1.00- \\
\$ 2.50 / \text { sy }\end{array}$ & Low & Some & No & Primary & $\mathrm{N} / \mathrm{A}$ & Some & Some & No & No \\
\hline $\begin{array}{l}\text { Native } \\
\text { Seeding } \\
\text { (Temporary) }\end{array}$ & CEC-9 & $\begin{array}{l}\$ 0.50- \\
\$ 1.00 / \text { sy }\end{array}$ & Medium & Some & Some & Primary & $\mathrm{N} / \mathrm{A}$ & Some & Some & No & No \\
\hline $\begin{array}{l}\text { Surface } \\
\text { Water } \\
\text { Diversion }\end{array}$ & $\begin{array}{l}\text { CEC-10 } \\
\text { CEC-11 } \\
\text { CEC-12 }\end{array}$ & Varies & Medium & No & No & Primary & $\mathrm{N} / \mathrm{A}$ & No & No & No & No \\
\hline $\begin{array}{l}\text { Turbidity } \\
\text { Curtain }\end{array}$ & CEC-13 & $\$ 15-25 /$ sy & Medium & No & No & $\mathrm{N} / \mathrm{A}$ & Primary & No & No & No & No \\
\hline Riprap & CEC-14 & Varies & Medium & No & No & Primary & Varies & No & No & No & No \\
\hline
\end{tabular}

TSS = Total Suspended Solids; P\&N = Phosphorus \& Nitrogen; Primary = Primary Design Benefit 


\section{B. CONSTRUCTION PHASE SEDIMENT CONTROL BMP PRACTICES APPROPRIATE FOR LINEAR PROJECTS}

\begin{tabular}{|c|c|c|c|c|c|c|c|c|c|c|c|}
\hline \multirow{3}{*}{$\begin{array}{l}\text { Suggested } \\
\text { BMPs }\end{array}$} & \multirow{3}{*}{$\begin{array}{l}\text { Fact } \\
\text { Sheet }\end{array}$} & \multirow{3}{*}{$\begin{array}{l}\text { Installation } \\
\text { Cost }\end{array}$} & \multirow{3}{*}{ Maintenance } & \multicolumn{2}{|c|}{$\begin{array}{c}\text { Water Quantity } \\
\text { Benefit }\end{array}$} & \multicolumn{6}{|c|}{ Water Quality Benefit } \\
\hline & & & & \multirow{2}{*}{$\begin{array}{c}\text { Rate } \\
\text { Control }\end{array}$} & \multirow{2}{*}{$\begin{array}{l}\text { Volume } \\
\text { Reduction }\end{array}$} & \multicolumn{2}{|c|}{$\begin{array}{c}\text { Pollution Prevention } \\
\text { Benefit }\end{array}$} & \multicolumn{4}{|c|}{ Pollutant Removal } \\
\hline & & & & & & $\begin{array}{l}\text { Erosion } \\
\text { Control }\end{array}$ & $\begin{array}{l}\text { Sediment } \\
\text { Control }\end{array}$ & TSS & P\&N & Metals & $\begin{array}{c}\text { Fecal } \\
\text { Coliform }\end{array}$ \\
\hline $\begin{array}{l}\text { Vehicle } \\
\text { Tracking } \\
\text { Pads }\end{array}$ & CSC-1 & $\begin{array}{l}\$ 2000- \\
4000 / \text { each }^{(2)}\end{array}$ & High & No & No & Secondary & Primary & Some & Some & Some & No \\
\hline Silt Fences & CSC-2 & $\begin{array}{l}\$ 1.00- \\
3.00 / \mathrm{ft}\end{array}$ & High & Some & No & $\mathrm{N} / \mathrm{A}$ & Primary & No & No & No & No \\
\hline $\begin{array}{l}\text { Inlet } \\
\text { Protection }\end{array}$ & CSC-3 & $\begin{array}{l}\$ 50- \\
150 / \text { inlet }\end{array}$ & High & No & No & $\mathrm{N} / \mathrm{A}$ & Primary & Yes & Some & Some & No \\
\hline $\begin{array}{l}\text { Sediment } \\
\text { Trap }\end{array}$ & CSC-4 & $\begin{array}{l}\$ 1,000- \\
\$ 1,500 / \text { per } \\
\text { acre of } \\
\text { drainage }\end{array}$ & High & Some & Some & $\mathrm{N} / \mathrm{A}$ & Primary & Yes & Some & Some & No \\
\hline $\begin{array}{l}\text { Rock Check } \\
\text { Dam }\end{array}$ & CSC-5 & $\$ 20-40 /$ ton & High & Some & Some & $\mathrm{N} / \mathrm{A}$ & Primary & Yes & Some & Some & No \\
\hline
\end{tabular}

TSS = Total Suspended Solids; P\&N = Phosphorus \& Nitrogen; Primary = Primary Design Benefit 


\section{CONSTRUCTION PHASE SEDIMENT CONTROL BMP PRACTICES RESERVED FOR NON-LINEAR PROJECTS}

\begin{tabular}{|c|c|c|c|c|c|c|c|c|c|c|c|}
\hline \multirow{3}{*}{$\begin{array}{l}\text { Suggested } \\
\text { BMPs }\end{array}$} & \multirow{3}{*}{$\begin{array}{l}\text { Fact } \\
\text { Sheet }\end{array}$} & \multirow{3}{*}{$\begin{array}{l}\text { Installation } \\
\text { Cost }\end{array}$} & \multirow{3}{*}{ Maintenance } & \multicolumn{2}{|c|}{$\begin{array}{c}\text { Water Quantity } \\
\text { Benefit }\end{array}$} & \multicolumn{6}{|c|}{ Water Quality Benefit } \\
\hline & & & & \multirow{2}{*}{$\begin{array}{c}\text { Rate } \\
\text { Control }\end{array}$} & \multirow{2}{*}{$\begin{array}{c}\text { Volume } \\
\text { Reduction }\end{array}$} & \multicolumn{2}{|c|}{$\begin{array}{c}\text { Pollution Prevention } \\
\text { Benefit }\end{array}$} & \multicolumn{4}{|c|}{ Pollutant Removal } \\
\hline & & & & & & $\begin{array}{l}\text { Erosion } \\
\text { Control }\end{array}$ & $\begin{array}{c}\text { Sediment } \\
\text { Control }\end{array}$ & TSS & $\mathbf{P} \& \mathbf{N}$ & Metals & $\begin{array}{c}\text { Fecal } \\
\text { Coliform }\end{array}$ \\
\hline $\begin{array}{l}\text { Sediment } \\
\text { Basin }\end{array}$ & CSC-6 & $\begin{array}{l}\$ 20-30 / \text { ton } \\
\text { material } \\
\text { removed }\end{array}$ & High & Some & Some & Primary & Primary & Yes & Some & Some & No \\
\hline
\end{tabular}

TSS = Total Suspended Solids; P\&N = Phosphorus \& Nitrogen; Primary = Primary Design Benefit

Notes:

(1) Adapted from the Minnesota Metropolitan Council's "Urban Small Sites Best Management Practice Manual" http://www.metrocouncil.org/environment/Watershed/BMP/manual.htm

(2) Assumes 50-ft long entrance with 30-ft radii at main roadway, 3" No. 53 stone over 12 " No 2 stone.

(3) Assumes earthwork is Common Excavation. Price would increase for factors such as wetness, or environmental contamination.

(4) Cost is usually not paid for directly, but hidden amongst the cost of various pay items. More detailed sequencing requirements will usually result in higher cost. 


\section{Overview of Common Post-Construction BMP Practices ${ }^{(1)}$}

\begin{tabular}{|c|c|c|c|c|c|c|}
\hline $\begin{array}{l}\text { BMP } \\
\text { Group }\end{array}$ & Fact Sheet(s) & Treatment Mechanism & $\begin{array}{c}\text { Common } \\
\text { Characteristics }\end{array}$ & Linear BMPs & $\begin{array}{l}\text { Non-Linear } \\
\text { BMPs }\end{array}$ & $\begin{array}{c}\text { Effective } \\
\text { Years of } \\
\text { Life }^{(3)}\end{array}$ \\
\hline $\begin{array}{l}\text { Detention } \\
\text { Systems }^{(2)}\end{array}$ & $\begin{array}{l}\text { PSC-1 } \\
\text { PSC-2 } \\
\text { PSC-3 } \\
\text { PSC-4 }\end{array}$ & Particulate settling & $\begin{array}{l}\text { Adequate hydrology } \\
\text { and soils required }\end{array}$ & Dry Swale & $\begin{array}{l}\text { Wet Pond } \\
\text { Extended } \\
\text { Detention Pond } \\
\text { Dry Pond }\end{array}$ & $\begin{array}{l}\text { Ponds: } \\
20-50 \\
\text { Swale: } \\
5-20\end{array}$ \\
\hline $\begin{array}{l}\text { Constructed } \\
\text { Wetlands }^{(2)}\end{array}$ & $\begin{array}{l}\text { PSC-5 } \\
\text { PSC-6 }\end{array}$ & $\begin{array}{l}\text { Particulate settling } \\
\text { Biological filtering }\end{array}$ & $\begin{array}{l}\text { Adequate hydrology } \\
\text { and soils required }\end{array}$ & $\begin{array}{l}\text { Stormwater } \\
\text { Wetland } \\
\text { Wet Swale }\end{array}$ & $\begin{array}{l}\text { Stormwater } \\
\text { Wetland }\end{array}$ & $\begin{array}{l}\text { Wetland: } \\
20-50 \\
\text { Swale } \\
5-20\end{array}$ \\
\hline $\begin{array}{l}\text { Infiltration } \\
\text { Systems }\end{array}$ & $\begin{array}{l}\text { PSC-7 } \\
\text { PSC-8 }\end{array}$ & $\begin{array}{l}\text { Adsorption } \\
\text { Biodegradation } \\
\text { Precipitation } \\
\end{array}$ & $\begin{array}{l}\text { Adequate soil media } \\
\text { critical }\end{array}$ & Infiltration Trench & Infiltration Basin & $5-15$ \\
\hline $\begin{array}{l}\text { Filtration } \\
\text { Systems }\end{array}$ & $\begin{array}{l}\text { PSC-9 } \\
\text { PSC-10 } \\
\text { PSC-11 } \\
\text { PSC-12 }\end{array}$ & $\begin{array}{l}\text { Straining } \\
\text { Adsorption } \\
\text { Chemical } \\
\text { transformation } \\
\text { Microbial decomposition }\end{array}$ & $\begin{array}{l}\text { Effective suspended } \\
\text { solids removal }\end{array}$ & $\begin{array}{l}\text { Bioretention } \\
\text { Filter Strip } \\
\text { Turf Reinforcement } \\
\text { Mat (TRM) })^{(4)} \\
\text { Native Seeding } \\
\text { (permanent) }^{(4)}\end{array}$ & $\begin{array}{l}\text { Bioretention } \\
\text { Filter Strip } \\
\text { Turf } \\
\text { Reinforcement } \\
\text { Mat (TRM) } \\
\text { Native Seeding } \\
\text { (permanent) }^{(4)} \\
\end{array}$ & $5-20$ \\
\hline $\begin{array}{l}\text { Water } \\
\text { Quality } \\
\text { Structures }\end{array}$ & PSC-13 & $\begin{array}{l}\text { Settling } \\
\text { Buoyancy of oils \& } \\
\text { floatables }\end{array}$ & Pretreatment & $\begin{array}{l}\text { Hydrodynamic } \\
\text { Separators }\end{array}$ & $\begin{array}{l}\text { Hydrodynamic } \\
\text { Separators }\end{array}$ & $50-100$ \\
\hline
\end{tabular}

(1) Adapted from "Stormwater Best Management Practices in an Ultra-Urban Setting: Selection and Monitoring", Federal Highway Administration http://www.fhwa.dot.gov/environment/ultraurb/uubmp3p1.htm)

(2) Assumes pretreatment with a sediment forebay (ponds and wetlands)

(3) Assumes effective regular maintenance is performed

(4) Not a stand alone post-construction BMP. Can increase the effectiveness of other BMPs when incorporated into their design and construction. 


\section{THREE-STEP PROCESS FOR BMP SELECTION}

The following outlines a process for selecting the best stormwater treatment BMP or group of BMPs to meet water quality and water quantity requirements as well as factors to consider for BMP placement. This outline guides the designer through a three step process adapted from Minnesota Metropolitan Council's "Urban Small Sites Best Management Practice Manual" and Maryland Department of the Environment's "Maryland Stormwater Design Manual". The steps progressively screen for:

- Physical Feasibility Factors

- Stormwater Treatment Suitability

- Community and Environmental Factors

The above noted reference documents are available online (as of November 2005) at the following web address links:

http://www.metrocouncil.org/environment/Watershed/BMP/manual.htm and http://www.mde.state.md.us/Programs/WaterPrograms/SedimentandStormwater/stormwater design/index.asp

\section{Step 1: Physical Feasibility Factors}

The first step addresses and allows the designer to determine whether development site conditions such as soils, terrain, depth to water table, drainage area, slope or head conditions, and area requirements will limit the use of a particular BMP.

Area Requirements - Linear or non-linear area requirements.

Soils - Evaluation of soils is based on USDA or NRCS hydrological soils group at the site.

Water Table - Indicates the minimum depth to the seasonally high water table from the bottom or floor of a BMP.

Drainage Area - Refers to the drainage area that is considered typical for the BMP.

Head - Estimate of the elevation difference needed at a site (from inflow to outflow).

Ultra-Urban Sites -BMPs that work well in urban environments, where space is limited and original soils have been disturbed.

\section{Step 2: Stormwater Treatment Suitability:}

Using those BMPs that are not eliminated in step one, identify BMPs effective at providing water quantity and water quality benefits. These include rate control, volume reduction, and percent removal of total suspended solids, phosphorus, nitrogen, metals, and fecal Coliform.

Water Quantity - Effectiveness of the BMP to control the rate and volume of stormwater runoff.

Water Quality - Indicates a BMPs ability to remove Total Suspended Solids (TSS), Phosphorus (P), Nitrogen (N), Metals, and fecal Coliform from stormwater runoff.

Accept Hotspot Runoff - Ability of the BMP to treat stormwater runoff from land uses that may produce highly polluted runoff (gas stations, maintenance facilities, salvage yards, and industrial sites). 


\section{Step 3: Community and Environmental Factors}

The remaining BMPs are then filtered through the third step. This step considers: frequency and cost of maintenance, construction cost, community acceptance, and benefit to wildlife.

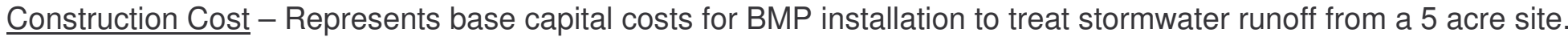

Low $=\$ 0-\$ 10,000$ for application of BMP on 5 acre site.

Medium $=\$ 10,001-\$ 20,000$ for application of BMP on 5 acre site.

High $=\$ 20,000+$ for application of BMP on 5 acre site.

Maintenance - Assesses the relative maintenance needed for a BMP based on frequency and cost of maintenance.

Community Acceptance - The community's acceptance of a BMP based on nuisance problems, visual orientation, and community preference surveys.

Wildlife Habitat - Ability to provide wildlife or wetland habitat based on size, water feature, wetland feature, and vegetative cover. 


\section{STEP 1 - PHYSICAL FEASIBILITY FACTORS}

Are there any physical constraints at the project site that may restrict or preclude the use of a particular BMP?

\begin{tabular}{|c|c|c|c|c|c|c|c|c|}
\hline BMP Group & Specific BMP & $\begin{array}{c}\text { Area } \\
\text { Requirements }\end{array}$ & $\begin{array}{l}\text { Soil } \\
\text { Groups }\end{array}$ & Terrain & $\begin{array}{c}\text { Water } \\
\text { Table }^{(1)} \\
\text { (ft) }\end{array}$ & $\begin{array}{c}\text { Drainage } \\
\text { Area }^{(2)} \\
\text { (acre) }\end{array}$ & $\begin{array}{l}\text { Head }^{(2)} \\
\text { (ft) }\end{array}$ & $\begin{array}{l}\text { Ultra } \\
\text { Urban }\end{array}$ \\
\hline \multirow{4}{*}{$\begin{array}{l}\text { Detention } \\
\text { Systems }\end{array}$} & Wet Pond & Non-linear & \multirow[b]{2}{*}{ C,D } & \multirow{2}{*}{$\begin{array}{c}\text { Low lying areas } \\
\text { (liner for karst } \\
\text { areas) }\end{array}$} & \multirow[b]{2}{*}{3} & \multirow[b]{2}{*}{$>2$} & \multirow[b]{2}{*}{$3-6$} & \multirow{4}{*}{ No } \\
\hline & $\begin{array}{l}\text { Extended Detention } \\
\text { Pond }\end{array}$ & Non-linear & & & & & & \\
\hline & Dry Pond & Non-linear & $\mathrm{Any}^{3)}$ & Low lying areas & 3 & $>2$ & $3-8$ & \\
\hline & Dry Swale & Linear & Any & Moderate slope & 3 & $2-4$ & $2-6$ & \\
\hline \multirow{2}{*}{$\begin{array}{l}\text { Constructed } \\
\text { Wetlands }\end{array}$} & Stormwater Wetland & Linear & $\operatorname{Any}^{(4)}$ & Low lying areas & 0 & $>1$ & $1-8$ & \multirow{2}{*}{ No } \\
\hline & Wet Swale & Linear & Any & Moderate slope & 0 & $<4$ & $2-3$ & \\
\hline \multirow{2}{*}{$\begin{array}{l}\text { Infiltration } \\
\text { Systems }\end{array}$} & Infiltration Trench & Linear & $A, B$ & No karst areas & 3 & $2-4$ & $3-8$ & Sometimes \\
\hline & Infiltration Basin & Non-linear & $A, B$ & No karst areas & 3 & $2-20$ & $3-4$ & No \\
\hline \multirow{4}{*}{$\begin{array}{l}\text { Filtration } \\
\text { Systems }\end{array}$} & Bioretention & Linear & Any & Low lying areas & 3 & $2-4$ & $2-3$ & Yes \\
\hline & Filter Strip & Linear & Any & Moderate slopes & 3 & $<5$ & Negligible & No \\
\hline & $\begin{array}{l}\text { Turf Reinforcement } \\
\text { Mat (TRM) }{ }^{(5)}\end{array}$ & Linear & Any & Any & $\mathrm{N} / \mathrm{A}$ & $\mathrm{N} / \mathrm{A}$ & $\mathrm{N} / \mathrm{A}$ & Yes \\
\hline & $\begin{array}{l}\text { Native Seeding } \\
\text { (permanent) }^{(5)}\end{array}$ & Linear & Any & Moderate Slope & $\mathrm{N} / \mathrm{A}$ & All & $\mathrm{N} / \mathrm{A}$ & Yes \\
\hline $\begin{array}{l}\text { Water Quality } \\
\text { Structures }\end{array}$ & $\begin{array}{l}\text { Hydrodynamic } \\
\text { Separators }\end{array}$ & Linear & Any & Any & $>3$ & Varies $^{(6)}$ & $\begin{array}{l}\text { Varies by } \\
\text { vendor }\end{array}$ & Yes \\
\hline
\end{tabular}

(1) Recommended minimum elevation above water table. Special consideration should be given if anticipated pollutant includes bacteria or other harmful constituents to drinking water or groundwater

(2) Adapted from "Stormwater Best Management Practices in an Ultra-Urban Setting: Selection and Monitoring", Federal Highway Administration http://www.fhwa.dot.gov/environment/ultraurb/uubmp3p1.htm)

(3) When dry ponds are installed in C or D type soils, the bottom of the basin should be sloped to allow for complete dewatering and avoid ponded areas. Perforated tile underdrains may also be installed for dewatering.

(4) Below water table.

(5) Not a stand alone post-construction BMP. Can increase the effectiveness of other BMPs when incorporated into their design and construction.

(6) Due to the increasing number of manufacturers of proprietary water quality structures, the upper limit of drainage area may vary from 2 to 300 acres. 


\section{STEP 2 - STORMWATER TREATMENT SUITABILITY}

Do the $B M P(s)$ from Step 1 provide needed water quantity and water quality benefit?

\begin{tabular}{|c|c|c|c|c|c|c|c|c|c|}
\hline \multicolumn{2}{|c|}{$\begin{array}{l}\text { Suggested } \\
\text { BMPs }\end{array}$} & \multicolumn{2}{|c|}{ Water Quantity Benefit } & \multicolumn{5}{|c|}{$\begin{array}{c}\text { Water Quality Benefit } \\
\text { \% Removed }\end{array}$} & \multirow{2}{*}{$\begin{array}{c}\text { Accept } \\
\text { Hotspot } \\
\text { Runoff }\end{array}$} \\
\hline BMP Group & Specific BMP & Rate Control & $\begin{array}{c}\text { Volume } \\
\text { Reduction }\end{array}$ & TSS & $\mathbf{P}$ & $\mathbf{N}$ & Metals & $\begin{array}{c}\text { Fecal } \\
\text { Coliform }\end{array}$ & \\
\hline \multirow{4}{*}{$\begin{array}{l}\text { Detention } \\
\text { Systems }\end{array}$} & Wet Pond & \multirow[b]{2}{*}{ High } & \multirow[b]{2}{*}{ Low } & \multirow[b]{2}{*}{$46-98$} & \multirow[b]{2}{*}{$20-94$} & \multirow[b]{2}{*}{$28-50$} & \multirow[b]{2}{*}{$24-89$} & \multirow[b]{2}{*}{$N / A$} & \multirow[b]{2}{*}{ Varies } \\
\hline & $\begin{array}{l}\text { Extended Detention } \\
\text { Pond }\end{array}$ & & & & & & & & \\
\hline & Dry Pond & High & Varies $^{(2)}$ & $67-93$ & $75-94$ & $\mathrm{~N} / \mathrm{A}$ & $\mathrm{N} / \mathrm{A}$ & $\mathrm{N} / \mathrm{A}$ & Varies \\
\hline & Dry Swale & Medium & Low & $30-90$ & $20-85$ & $0-50$ & $0-90$ & $\mathrm{~N} / \mathrm{A}$ & Yes \\
\hline \multirow{2}{*}{$\begin{array}{l}\text { Constructed } \\
\text { Wetlands }\end{array}$} & Stormwater Wetland & High & Low & 65 & 25 & 20 & $35-65$ & $N / A$ & No \\
\hline & Wet Swale & Low & Low & 65 & 25 & 20 & $35-65$ & $\mathrm{~N} / \mathrm{A}$ & No \\
\hline \multirow{2}{*}{$\begin{array}{l}\text { Infiltration } \\
\text { Practices }\end{array}$} & Infiltration Trench & Medium & High & $75-99$ & $50-75$ & $45-70$ & $75-99$ & $75-98$ & No \\
\hline & $\begin{array}{l}\text { Infiltration } \\
\text { Basin }\end{array}$ & Medium & High & $75-99$ & $50-75$ & $45-70$ & $50-90$ & $75-98$ & No \\
\hline \multirow{4}{*}{$\begin{array}{l}\text { Filtration } \\
\text { Systems }\end{array}$} & Bioretention & Medium & Medium & 75 & 50 & 50 & $75-80$ & $\mathrm{~N} / \mathrm{A}$ & Yes \\
\hline & Filter Strip & Medium & Medium & $27-70$ & $20-40$ & $20-40$ & $2-80$ & $\mathrm{~N} / \mathrm{A}$ & Yes \\
\hline & $\begin{array}{l}\text { Turf Reinforcement } \\
\text { Mat (TRM) }{ }^{(5)}\end{array}$ & Low & Low & $81^{4}$ & $9^{4}$ & $38^{4}$ & $42-71^{4}$ & $\mathrm{~N} / \mathrm{A}$ & No \\
\hline & $\begin{array}{l}\text { Native Seeding } \\
{\text { (permanent })^{(5)}}^{\text {perma }}\end{array}$ & Low & Low & $81^{4}$ & $9^{4}$ & $38^{4}$ & $42-71^{4}$ & $N / A$ & No \\
\hline $\begin{array}{l}\text { Proprietary } \\
\text { Systems }^{(3)}\end{array}$ & $\begin{array}{l}\text { Hydrodynamic } \\
\text { Separators }\end{array}$ & None & None & $80-90$ & $\mathrm{~N} / \mathrm{A}$ & $N / A$ & $\mathrm{~N} / \mathrm{A}$ & $\mathrm{N} / \mathrm{A}$ & Yes \\
\hline
\end{tabular}

(1) Adapted from "Stormwater Best Management Practices in an Ultra-Urban Setting: Selection and Monitoring", Federal Highway Administration http://www.fhwa.dot.gov/environment/ultraurb/uubmp3p1.htm)

(2) Dry pond volume reduction highly dependent on soil permeability.

(3) Not a stand alone post-construction BMP. Can increase the effectiveness of other BMPs when incorporated into their design and construction.

(4) Median percent removal for vegetates swales from United States Environmental Protection Agency Office of Water. EPA 832-F-99-006 Storm Water Technology Fact Sheet Vegetated Swales September 1999.

(5) Due to variability of units, refer to independent data supplied by manufacturer. 


\section{STEP 3 - COMMUNITY \& ENVIRONMENTAL FACTORS}

Are there important community or environmental factors that might influence the selection process of the remaining BMPs?

\begin{tabular}{|c|c|c|c|c|c|c|}
\hline \multirow[b]{2}{*}{ BMP Group } & \multirow[b]{2}{*}{ Specific BMP } & \multirow{2}{*}{$\begin{array}{c}\text { Construction } \\
\text { Cost } \\
(5 \text {-acre site })^{1}\end{array}$} & \multicolumn{2}{|c|}{ Maintenance } & \multirow[b]{2}{*}{$\begin{array}{l}\text { Community } \\
\text { Acceptance }\end{array}$} & \multirow[b]{2}{*}{ Wildlife Habitat } \\
\hline & & & Frequency & $\begin{array}{c}\text { Annual Cost } \\
\text { (based on } \\
\text { Construction } \\
\text { Cost) }^{1}\end{array}$ & & \\
\hline \multirow{4}{*}{$\begin{array}{l}\text { Detention } \\
\text { Systems }\end{array}$} & Wet Pond & Low & Annual & $3-5 \%$ & Moderate & Medium \\
\hline & $\begin{array}{l}\text { Extended Detention } \\
\text { Pond }\end{array}$ & Low & Annual & $3-5 \%$ & Moderate & Medium \\
\hline & Dry Pond & Low & $\begin{array}{l}\text { Mowing } \\
\text { Schedule }\end{array}$ & $5-7 \%$ & Moderate & Low \\
\hline & Dry Swale & Low & Annual & $3-5 \%$ & Moderate & Low \\
\hline \multirow{2}{*}{$\begin{array}{l}\text { Constructed } \\
\text { Wetlands }\end{array}$} & Stormwater Wetland & Medium & Annual & $5-7 \%$ & Moderate to High & High \\
\hline & Wet Swale & Medium & $\begin{array}{l}\text { Mowing } \\
\text { Schedule }\end{array}$ & $5-20 \%$ & Moderate & Medium \\
\hline \multirow{2}{*}{\begin{tabular}{|l|} 
Infiltration \\
Systems \\
\end{tabular}} & Infiltration Trench & High & Biannual & $5 \%-7 \%$ & Moderate to High & None \\
\hline & Infiltration Basin & Medium & Biannual & $5-20 \%$ & Moderate & Low \\
\hline \multirow{4}{*}{$\begin{array}{l}\text { Filtration } \\
\text { Systems }\end{array}$} & Bioretention & High & $\begin{array}{l}\text { Mowing } \\
\text { Schedule }\end{array}$ & $5-7 \%$ & Moderate & Medium \\
\hline & Filter Strip & Low & $\begin{array}{l}\text { Mowing } \\
\text { Schedule }\end{array}$ & $5-7 \%$ & High & Medium \\
\hline & $\begin{array}{l}\text { Turf Reinforcement } \\
\text { Mat (TRM) }\end{array}$ & Medium & $\begin{array}{l}\text { Meeting } \\
\text { Schedule }\end{array}$ & $1-5 \%$ & High & Medium \\
\hline & $\begin{array}{l}\text { Native Seeding } \\
\text { (permanent) }\end{array}$ & Low & Annual & $1-5 \%$ & High & Medium \\
\hline \begin{tabular}{|l|} 
Water Quality \\
Structures \\
\end{tabular} & $\begin{array}{l}\text { Hydrodynamic } \\
\text { Separators }\end{array}$ & High & Biannual & $1-5 \%$ & High & None \\
\hline
\end{tabular}

1. United States Environmental Protection Agency, Office of Water. EPA-821-R-99-012: Preliminary Data Summary of Urban Storm Water Best Management Practices-Chapter 6: Costs and Benefits of Stormwater BMPs, August 1999.

2. United State Environmental Protection Agency, Office of Water. EPA-821-99-002: Stormwater Technology Fact Sheet Turf Reinforced Mats, September 1999 
APPENDIX 3

CONSTRUCTION PHASE BMP FACT SHEETS 


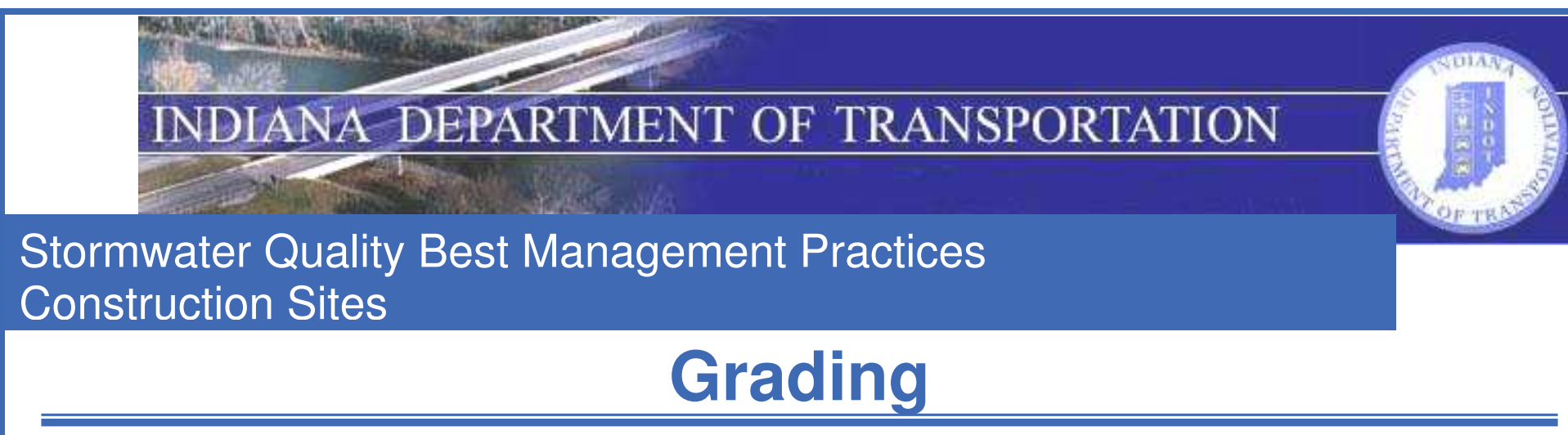

\section{When to use:}

- Land grading, as an erosion control measure, is applicable to sites with uneven or steep topography or easily erodible soils

- Grading plans that minimize erosion potential can be applied to all projects

\section{Advantages:}

- Careful planning in this area can significantly reduce construction and long term erosion

\section{Limitations:}

- Extensive grading increases costs

\section{Description:}

Grading can be planned and used during and after construction to control surface runoff and minimize soil erosion and sedimentation. Grading activities should maintain existing drainage patterns where possible, and minimize slope lengths and steepness. (EPA, 2000)

Grading practices, such as selecting a milder side slope gradient (e.g. 6:1 vs. 3:1), can help reduce runoff velocity and help prevent rill erosion. Final grades selected should be based on considerations of the soil characteristics at the specific site (e.g. sands vs. clays). Upon completion of grading activities or when a slope will remain disturbed for extended timeframes, slopes should be track-walked from bottom to top with tracked machinery. This practice reduces rill erosion and runoff velocities.

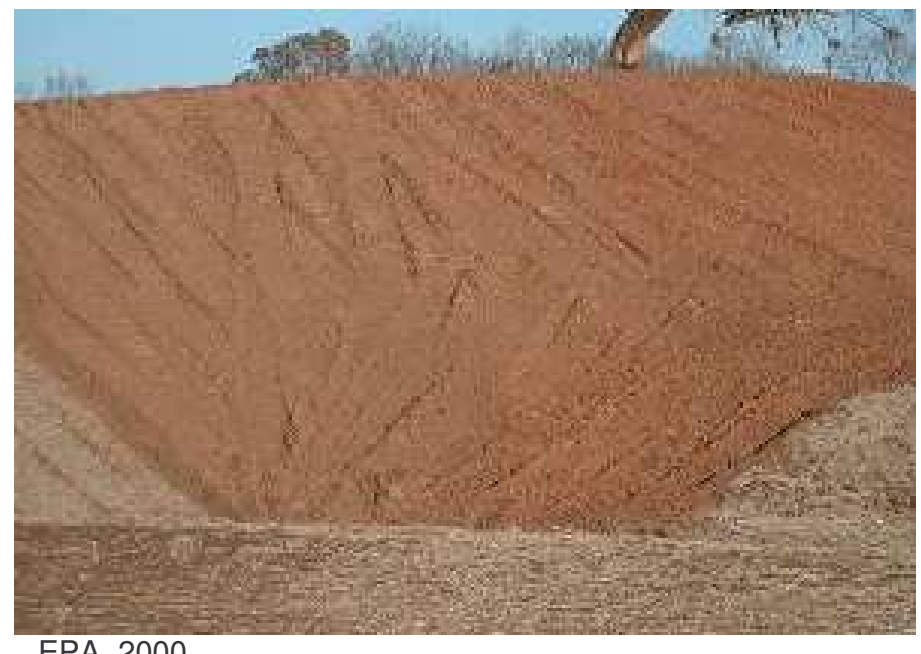




\section{Grading}

\section{Drawings:}

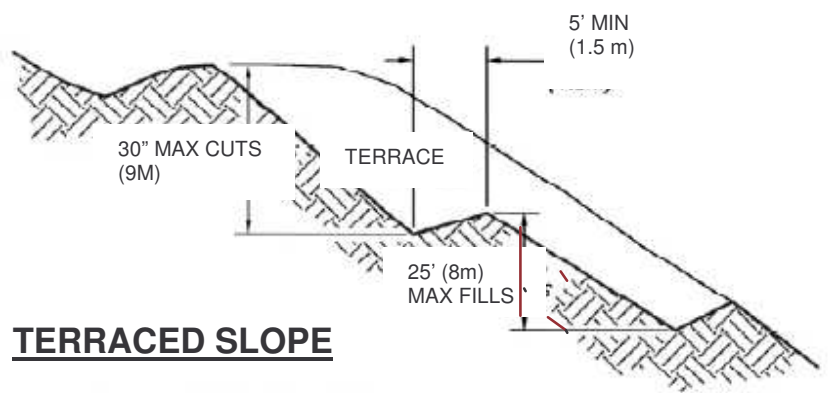

Figure1: Terracing

(North Augusta, 2004)

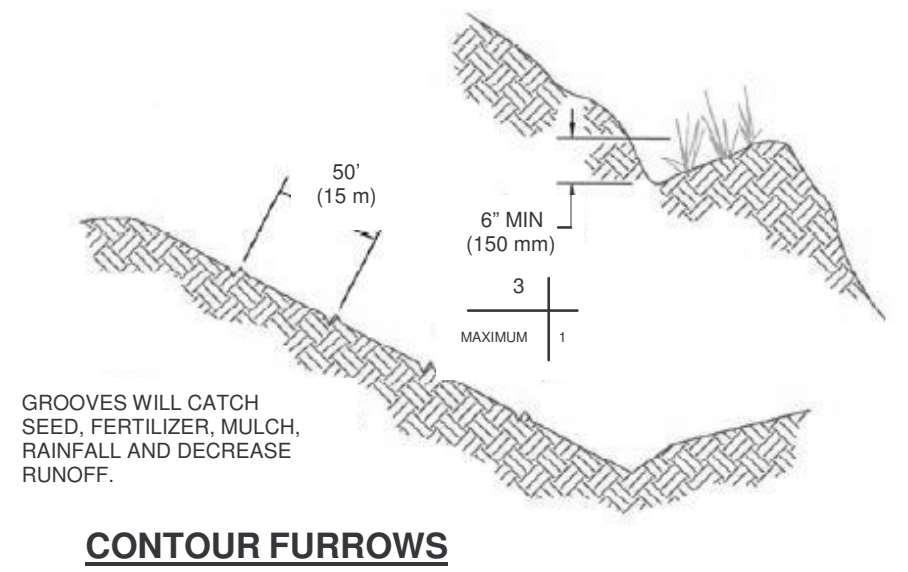

Figure 2: Contour Furrows

(North Augusta, 2004)

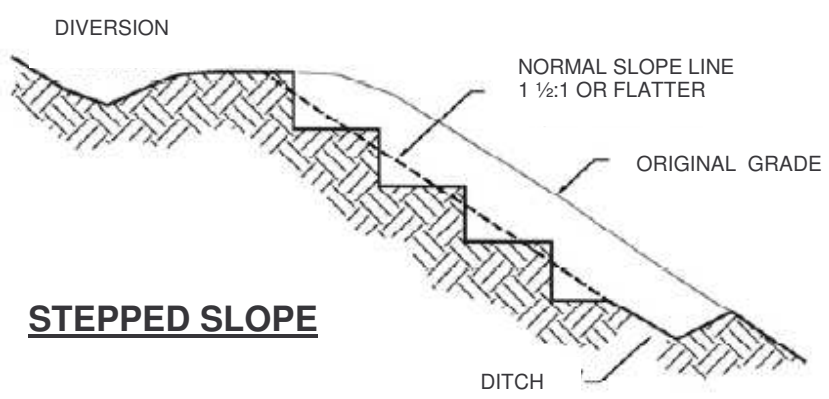

Figure 3: Stepped Slope

(North Augusta, 2004)

Reference:

EPA, 2000. EPA's Storm Water Phase II Menu of Best Management Practices. Environmental Protection Agency, National Pollution Discharge Elimination System, Stormwater Team.

http://cfpub2.epa.gov/NPDES/stormwater/menuofbmps/pdf/small_files/main.pdf

North Augusta , 2004. The City of North Augusta Erosion and Sediment Control Manual. City of North Augusta, Stormwater Management Department.

http://www.northaugusta.net/Dept_Serv/Engin_PublicWorks/stormwater/developers.htm 
INDIANA DEPARTMENT OF TRANSPORTATION
Stormwater Quality Best Management Practices
Construction Sites

\section{When to use:}

- Appropriate on all soil types

- Where wind erosion may be a problem

- To aid in vegetation (seed) establishment.

- To reduce rill and gully erosion on slopes.

\section{Advantages:}

- Reduces both water and wind erosion.

- Improves vegetation establishment.

- Inexpensive for short-term erosion control when used with other measures.

BMP Type:

Installation Cost:

Maintenance Effort:

Runoff Rate Control:

Runoff Volume Control: No

\section{Limitations:}

- Not appropriate for rocky slopes.

- Can lead to soil compaction

- Significant rainfall limits effectiveness

- Should be combined with seeding, mulching, or erosion control blanket.

- Limited to exposed slopes mild enough to be traversed by appropriate equipment (approximately 2:1 slope)

\section{Description:}

Soil roughening is a temporary erosion control practice useful with grading operations associated with sloped areas. Soil roughening involves increasing the relief of a bare soil surface with horizontal grooves, stair-stepping (running parallel to the contour of the land), or tracking using a cleated roller, crawler tractor, or similar construction equipment. Slopes that are not fine graded and that are left in a roughened condition can reduce erosion. Soil roughening reduces runoff velocity, increases infiltration, reduces erosion, traps sediment, and prepares the soil for seeding and planting by giving seed an opportunity to take hold and grow. It also reduces erosion and sedimentation resulting from wind (EPA, 2000).

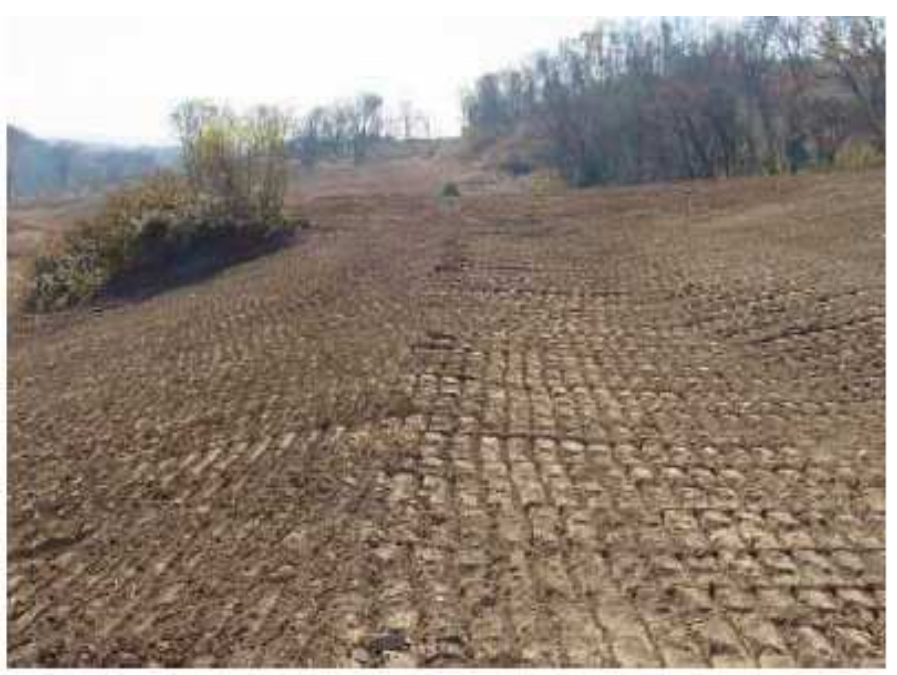

TDEC, 2002
Construction

Practice

$\$ 0.10-0.50 /$ sy

Low to Medium

Some 


\section{Soil Roughening}

\section{Drawings:}

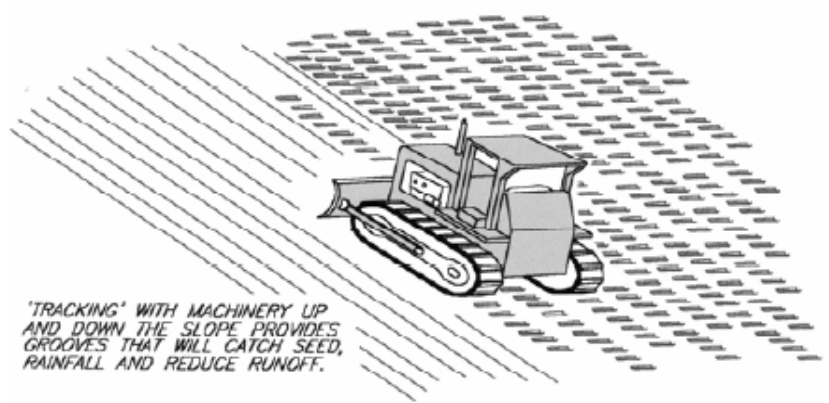

TRACKING

Figure 1: Machine Tracking

(North Augusta, 2004)

\section{References:}

EPA, 2000. EPA's Storm Water Phase II Menu of Best Management Practices. Environmental Protection Agency, National Pollution Discharge Elimination System, Stormwater Team.

http://cfpub2.epa.gov/NPDES/stormwater/menuofbmps/pdf/small_files/main.pdf

North Augusta , 2004. The City of North Augusta Erosion and Sediment Control Manual. City of North Augusta, Stormwater Management Department.

http://www.northaugusta.net/Dept_Serv/Engin_PublicWorks/stormwater/developers.htm 


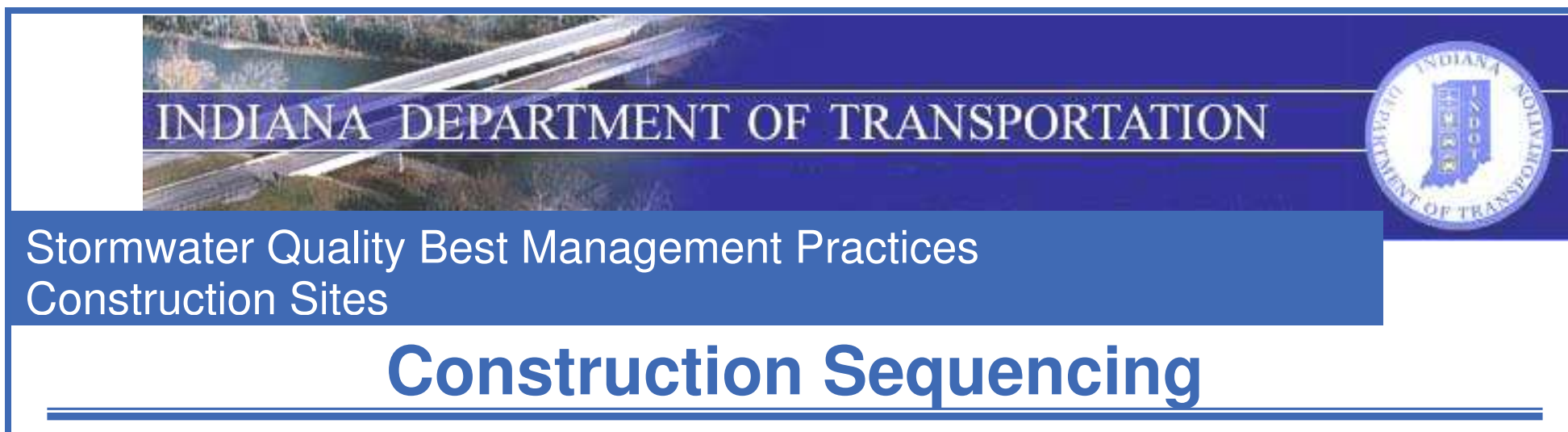

\section{When to use:}

- All projects that involve land disturbance activity

\section{Advantages:}

- Reduce the cost of erosion and sediment control portion of a project

- Can improves efficiency and effectiveness of erosion and sediment control measures

- Reduces the gross amount of disturbed or active construction at a given time

\section{Limitations:}

- Often requires field adjustments for unforeseen circumstances to initial plan

- Weather conditions can interfere with initial sequencing plan

\section{Description:}

A construction sequence schedule is a specified work schedule that coordinates the timing of land-disturbing activities and the installation of erosion-protection and sedimentation-control measures. Sequencing includes phasing of construction through sequential development of smaller portions of a large project site. Each portion is stabilized before beginning land disturbance on subsequent portions, to minimize exposure of disturbed land to erosion.

BMP Type:

Installation Cost:

Maintenance Effort:

Runoff Rate Control:

Runoff Volume Control:
Construction

Practice

Varies

Medium

No

No

\author{
Phase I Construction Area<smiles>[AlH]</smiles> \\ Install Erosion and Sediment \\ Control Measures \\ $\downarrow$ \\ Begin Clearing and Grubbing \\ Maintain Erosion and Sediment \\ Control Measures \\ $\downarrow$ \\ Stabilize Phase I \\ Construction Area \\ Proceed to Next Phase of \\ Construction Area \\ Continue Process of Phased \\ Disturbance and Stabilization \\ Through Final Site \\ Stabilization
}




\section{Construction Sequencing}




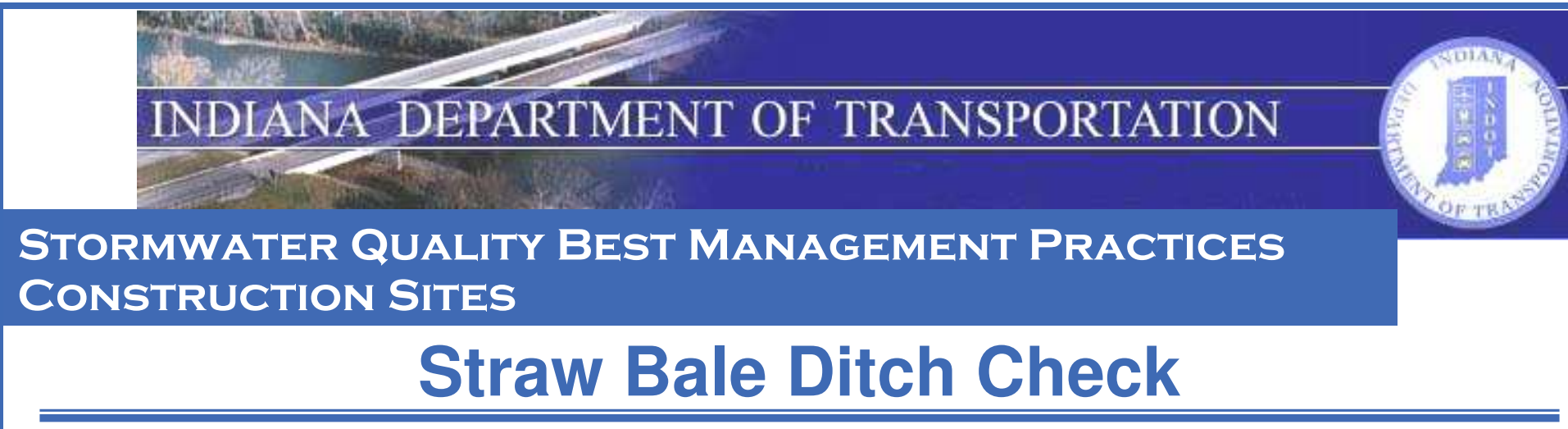

\section{When to use:}

- Concentrated flow areas such as vegetated ditches and swales

- Should NOT be used in streams

- Where temporary seeding has recently been implemented

\section{Advantages:}

- Low installation cost

- Not a traffic hazard

\section{Limitations:}

- High failure rate

- Improper installation can facilitate erosion around ends of check dams

- Difficult to maintain and remove completely

\section{Description:}

Straw bale ditch checks are small dams constructed across a swale or ditch. Straw bale ditch checks are used to slow the velocity of concentrated flow thereby reducing erosion. As a lesser function, straw bale ditch checks can also be used to catch sediment from the swale itself or from the contributing drainage area as storm water runoff flows through the structure. However, the use of straw bale ditch checks should not be a substitute for the use of other sediment-trapping and erosion control measures. Straw bale ditch checks are most effective when used in combination with other storm water and erosion and sediment control measures (Metropolitan Council, 2001).

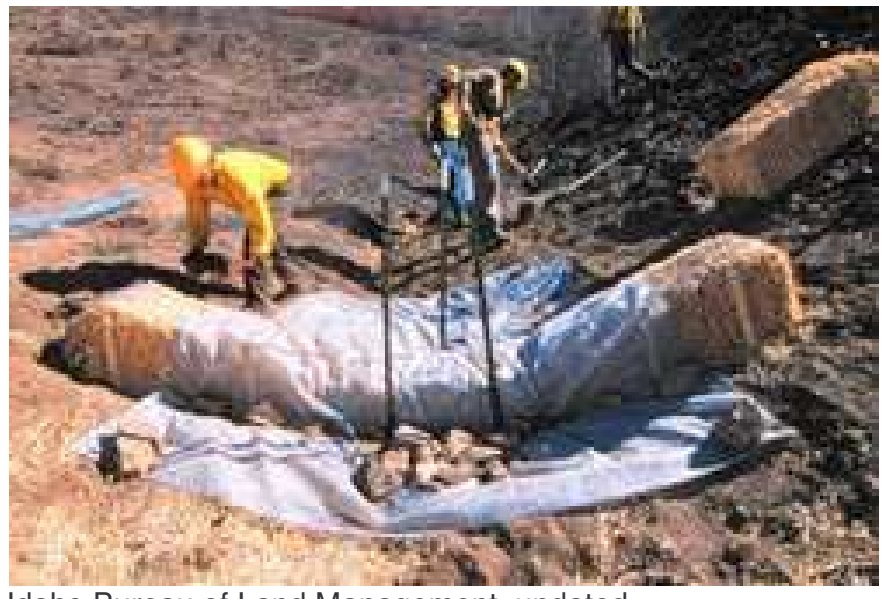

Idaho Bureau of Land Management, undated
Sediment Control Linear

Installation Cost:

Maintenance Effort:

Runoff Rate Control:

$\$ 4.00-\$ 8.00 / \mathrm{ft}$

High

Some

Runoff Volume Control: No 


\section{Straw Bale Ditch Check}

\section{Drawings:}

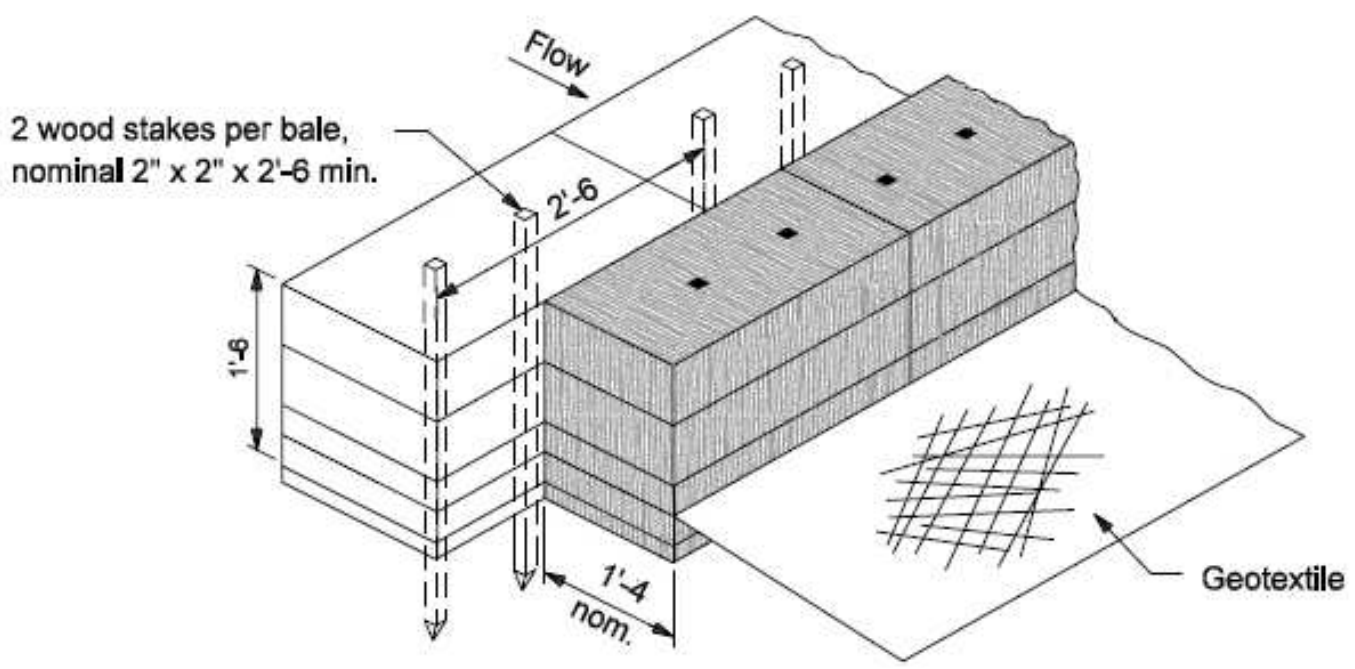

Figure 1: Isometric View

(INDOT, 2005, Standard Drawings)

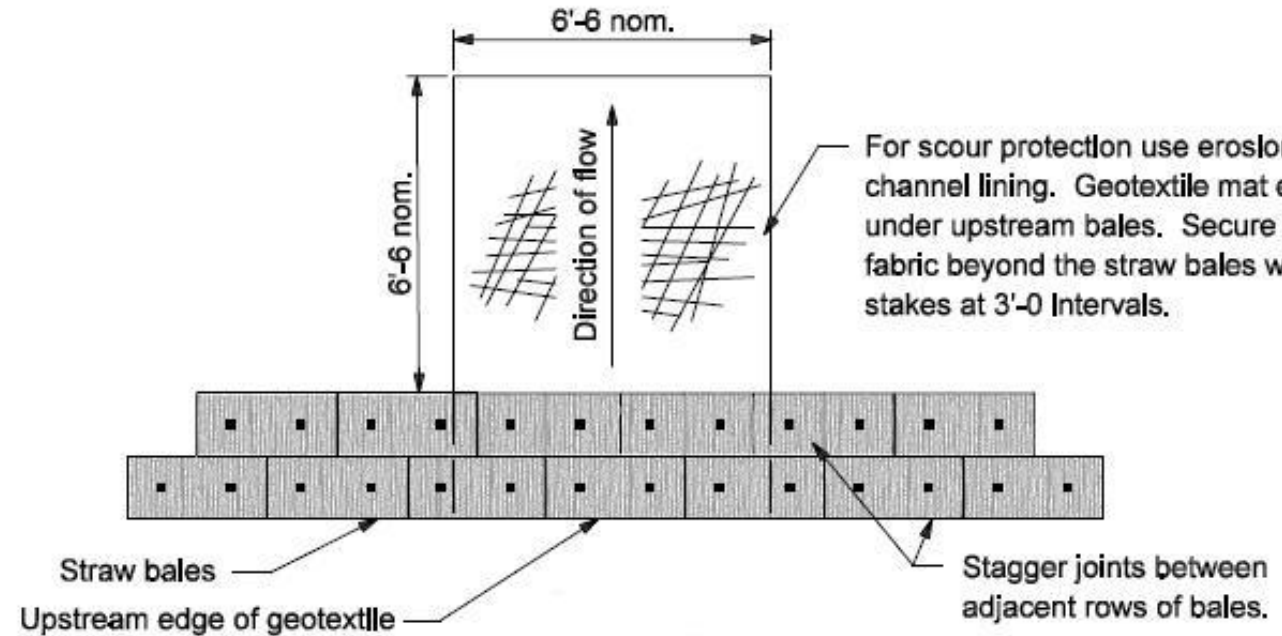

mat should be even with upstream edge of strawbales.

Figure 2: Plan View

(INDOT, 2005, Standard Drawings)

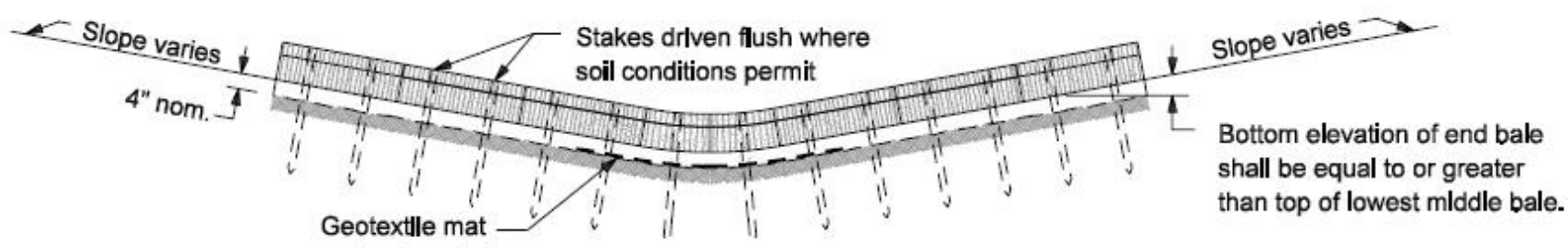
under straw bales

Figure 3: Front View

(INDOT, 2005, Standard Drawings) 


\section{Straw Bale Ditch Check}

\section{References:}

EPA, 2000. EPA's Storm Water Phase II Menu of Best Management Practices. Environmental Protection Agency, National Pollution Discharge Elimination System, Stormwater Team. http://cfpub2.epa.gov/NPDES/stormwater/menuofbmps/pdf/small files/main.pdf

INDOT, 2005. Indiana Department of Transportation Design Manual, Part 4, Chapter 37 - Temporary Erosion and Sediment Control. Indiana Department of Transportation, Division of Design.

http://www.in.gov/dot/div/contracts/standards/dm/Part4Vol.2/Ch37/ch37.htm

INDOT, 2005. Indiana Department of Transportation Standard Drawings - Sections 100 through 300. Effective Sept. 2005. Indiana Department of Transportation, Division of Design.

http://www.in.gov/dot/div/contracts/standards/drawings/sep05/e/sep1 to3.htm 


INDIANA DEPARTMENT OF TRANSPORTATION
Stormwater Quality Best Management Practices
Construction Sites
Fber Watte Roll Ditch Check

\section{When to use:}

- Concentrated flow areas such as vegetated ditches and swales

- Should NOT be used in streams

- Where temporary seeding of channels has been recently implemented

\section{Advantages:}

- Can be left in place after site is stabilized

- Not a traffic hazard

\section{Limitations:}

- Can wash away if not well anchored

- Improper installation can facilitate erosion around ends of check dams

\section{Description:}

A fiber wattle roll consists of straw, flax or other similar materials that are rolled and bound into a tight roll that is generally placed on the face of slopes at regular intervals to intercept runoff, reduce flow velocity, release the runoff as sheet flow and provide the removal of sediment. When used as a ditch check, it slows the velocity of concentrated flow in a channel thereby reducing the erosion in the swale or channel (Caltrans, 2005).

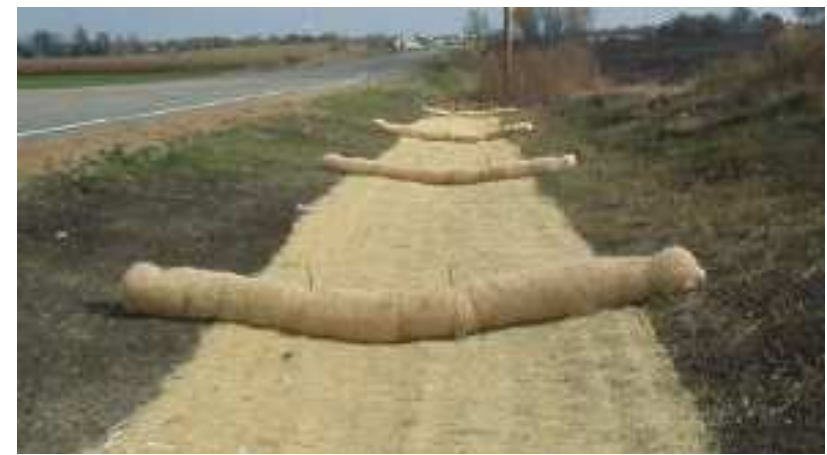

Carver County, undated
Sediment Control Linear

Installation Cost:

Maintenance Effort:

Runoff Rate Control:

$\$ 6.00-\$ 8.00 / \mathrm{ft}$

Medium

Some

No 


\section{Fiber Wattle Roll Ditch Check}

\section{Drawings:}

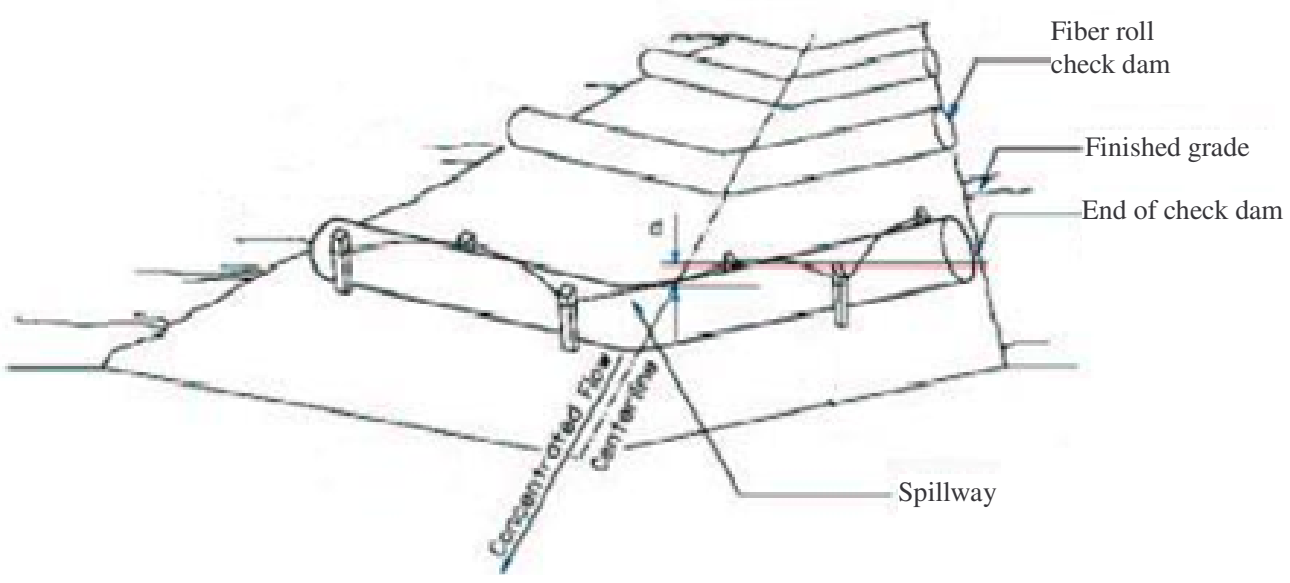

Figure 1: Fiber Wattle Roll Ditch Check with Tie-Downs

(Caltrans, 2003)

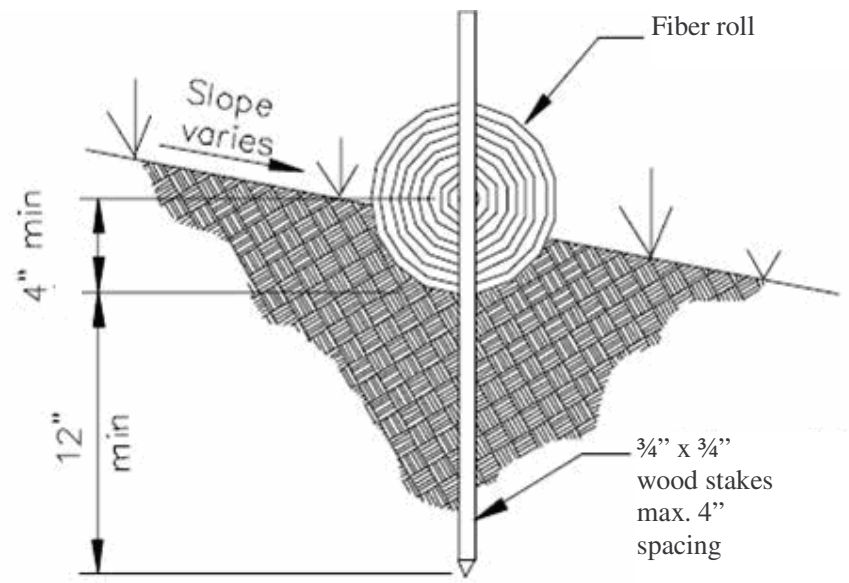

Figure 2: Fiber Wattle Roll Anchored by Staking - Cross Section

(Caltrans, 2002)
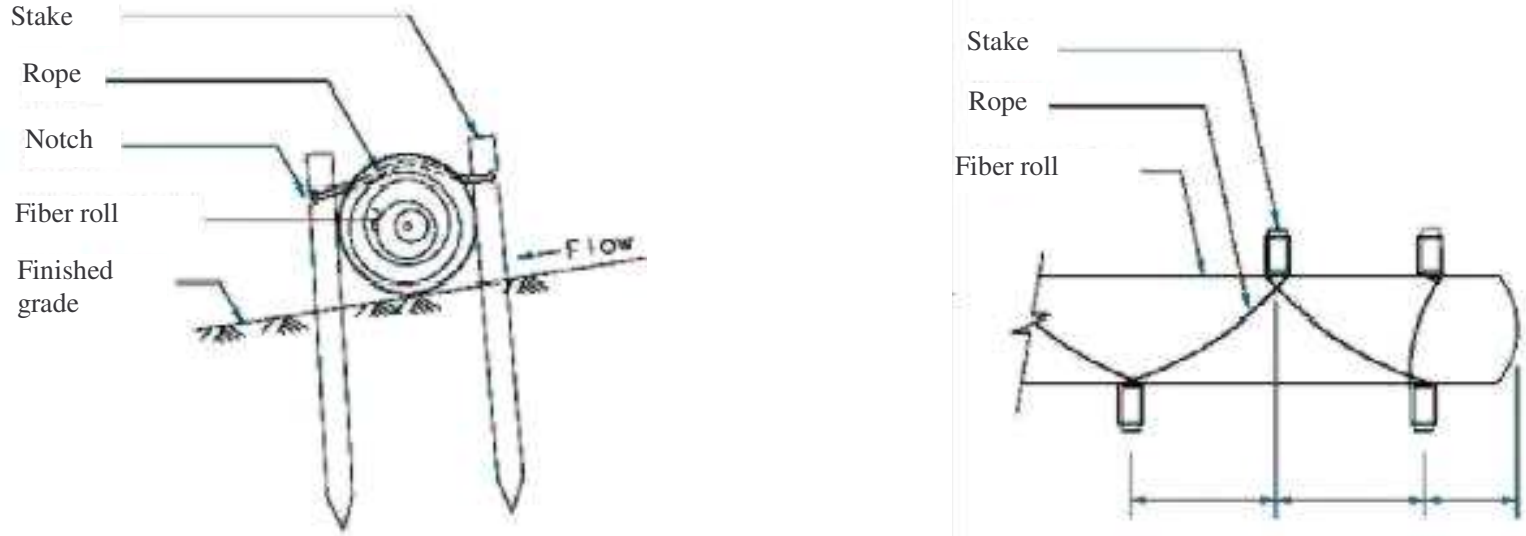

Figure 3: Tie-Downs - Cross Section (Caltrans, 2003)

Figure 4: Tie-Downs - Plan View (Caltrans, 2003) 


\section{Fiber Wattle Roll Ditch Check}

\section{References:}

Caltrans, 2005. Caltrans Storm Water Quality Handbooks Project Planning and Design Guide. State of California Department of Transportation.

http://www.dot.ca.gov/hq/oppd/stormwtr/PPDG-with-revisions-7-26-05.pdf

Caltrans, 2003. Caltrans Storm Water Quality Handbooks Construction Site Best Management Practices Manual. State of California Department of Transportation.

http://www.dot.ca.gov/hq/construc/stormwater/details.htm

Carver County, Undated, Construction Site Erosion and Sediment Control for Small Sites - Fiber Rolls. Department of Planning \& Zoning, Carver County, Minnesota.

http://www.co.carver.mn.us/water/user_documents/FiberRolls.pdf 


\section{INDIANA DEPARTMENT OF TRANSPORTATION}

\section{Stormwater Quality Best Management Practices Construction Sites}

\section{Straw Mulch}

\section{When to use:}

- On bare areas that will be undisturbed for 14 or more days

- To protect seeding and sensitive plantings

- Where temporary seeding can not be used (due to growing season or scheduling)

\section{Advantages:}

- Provides an immediate, effective, and inexpensive erosion control

- Improves the success of temporary and permanent seeding

\section{Limitations:}

- Straw can be washed away with heavy rainfall

- May delay seed germination due to increased soil temperature

\section{Description:}

Straw mulching is a temporary erosion control practice. Mulching is highly recommended as a stabilization method and is most effective when used in conjunction with vegetation establishment. Mulching can also reduce storm water runoff velocity. When used in combination with seeding or planting, mulching can aid plant growth by holding seeds, fertilizers, and topsoil in place, preventing birds from eating seeds, retaining moisture, and insulating plant roots against extreme temperatures. (EPA, 2000) The effectiveness of straw mulch may be increased when mulch is applied with a tackifier.

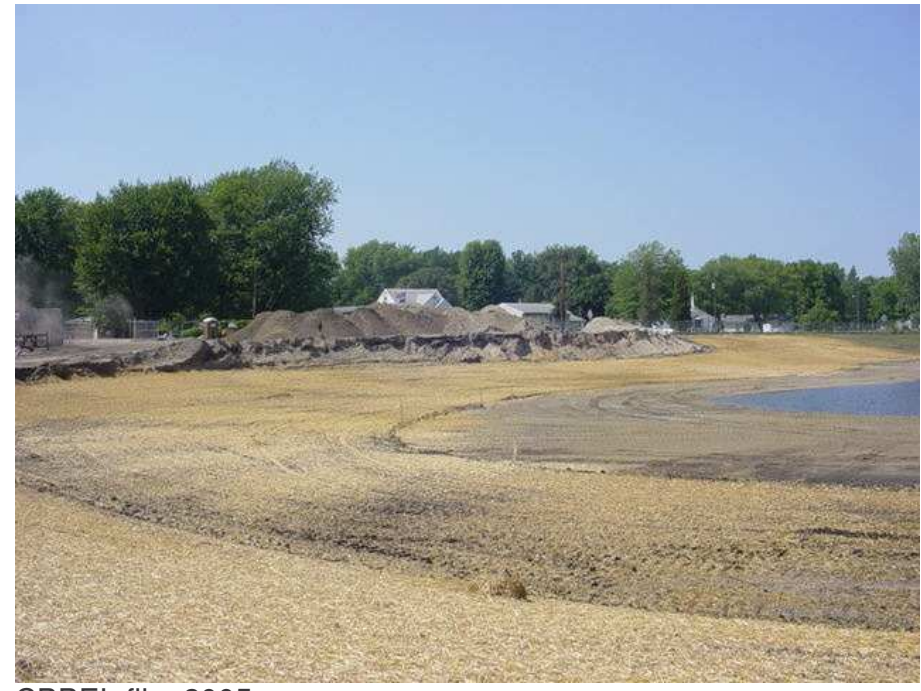

\section{References:}

EPA, 2000. EPA's Storm Water Phase II Menu of Best Management Practices. Environmental Protection Agency, National Pollution Discharge Elimination System, Stormwater Team. http://cfpub2.epa.gov/NPDES/stormwater/menuofbmps/pdf/small_files/main.pdf 


\section{Straw Mulch}


INDIANA DEPARTMENT OF TRANSPORTATION
Stormwater Quality Best Management Practices
Construction Sites
Bonded Floer Matrix Mulch

\section{When to use:}

- Steep slopes

- Areas that are not accessible for conventional mulching or erosion control blanket installation

\section{Advantages:}

- Can be used on steep slopes where other covers would not adhere to slope

- Reduced labor requirements

- Provides immediate, temporary surface stabilization

\section{Limitations:}

- Specialized installation methods

\section{Description:}

A bonded fiber matrix (BFM) refers to a continuous layer of elongated wood fiber strands that are held together by a water-resistant bonding agent to form a water-absorbing crust. When properly dried, this acts as an erosioncontrol blanket. This mulch is applied with a mechanically agitated pumping machine (hydroseeder). Properly applied, bonded fiber matrices can provide excellent erosion protection and revegetative support (Metropolitan Council, 2001).

\section{References:}

BMP Type:

Installation Cost:

Maintenance Effort:

Runoff Rate Control:

Runoff Volume Control: No
Erosion Control

Linear

$\$ 1.50-\$ 2.50 /$ sy

Low

Some

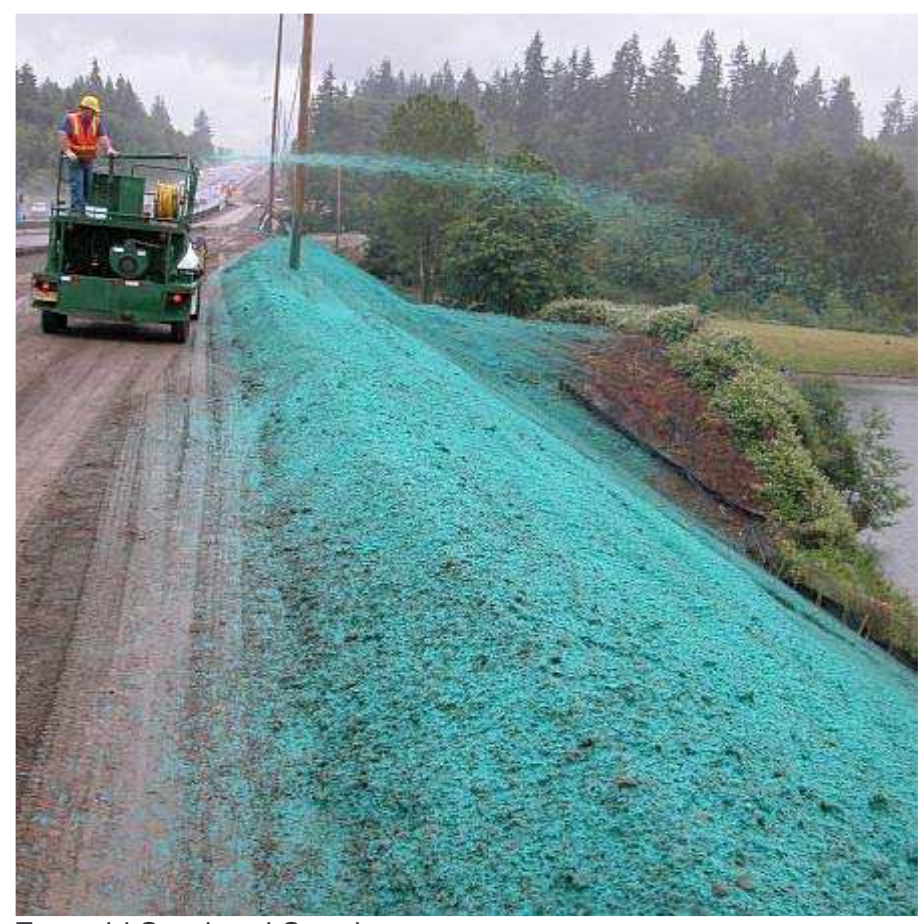

Emerald Seed and Supply

Emerald Seed and Supply, 2005. Bonded Fiber Matrix Mulch product webpage.

http://www.emeraldseedandsupply.com/erosioncontrol/ec_bfm.html

Metropolitan Council, 2001. Minnesota Urban Small Sites BMP Manual, Stormwater Best Management Practices for Cold Climates. Metropolitan Council Environmental Services. http://www.metrocouncil.org/environment/Watershed/BMP/manual.htm 
INDIANA DEPARTMENT OF TRANSPORTATION
Stormwater Quality Best Management Practices
Construction Sites
Erosion Control Blahket

\section{When to use:}

- On steep slopes

- In areas with concentrated flow such as ditches and swales

- Where the soil is erodible but will support vegetation

\section{Advantages:}

- Can use in areas where other mulches would wash away

- Works well as a stand alone measure

\begin{tabular}{|ll}
\hline BMP Type: & Erosion Control \\
& Linear \\
Installation Cost: & $\$ 1.00-\$ 2.50 /$ sy \\
Maintenance Effort: & Low \\
Runoff Rate Control: & Some \\
Runoff Volume Control: & No
\end{tabular}

\section{Limitations:}

- Labor intensive installation

- Improper installation can lead to gully erosion beneath the blanket

- Must be stored properly prior to installation to avoid degradation.

\section{Description:}

Erosion control blankets are made of biodegradable materials such as jute matting, excelsior wood fiber, coconut fiber, straw or interwoven paper strips, and a netting made of a biodegradable polypropylene or extruded plastic. These materials are formed into sheets that are used as temporary or permanent mulching to stabilize disturbed slopes. Erosion control blankets provide the same benefits as other types of mulching, but are much more stable and longer lasting than normal mulches and can be used in areas of moderate concentrated flow such as ditches and swales (MDOT, 2002).

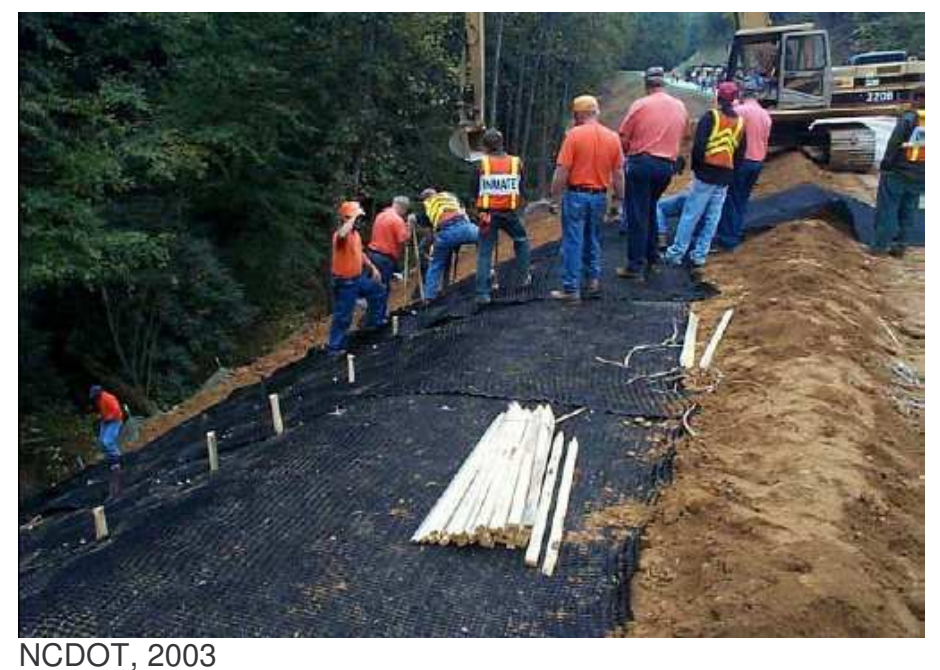




\section{Erosion Control Blanket}

References:

MDOT, 2002. Maine Department of Transportation Best Management Practices (BMPs) for Erosion and Sedimentation Control. Maine Department of Transportation, Environmental Office, Surface Water Resources Unit.

http://mainegov-images.informe.org/mdot/contractor-consultant-information/bmprevision90602.pdf

NCDOT, 2003. Best Management Practices for Construction and Maintenance Activities. North Carolina Department of Transportation, Division of Highways, Highway Operations.

http://www.ncdot.org/doh/operations/BMP_Manual/download/BMP_Manual.pdf 


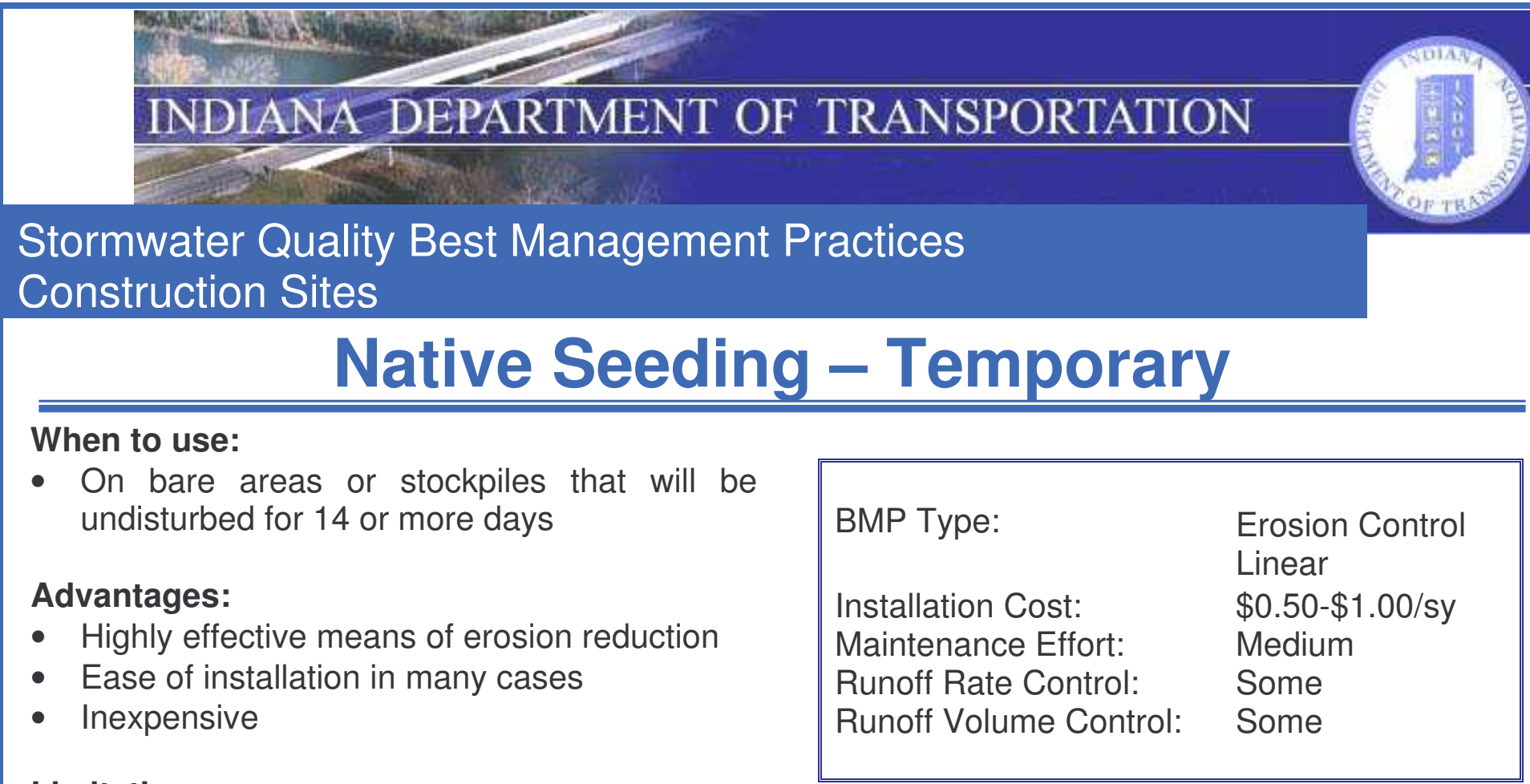

\section{Limitations:}

- Establishment can be hampered by weather conditions

- Can not establish vegetation during winter months

\section{Description:}

The first step in erosion control on construction sites is to limit the extent of cleared vegetation. The next step is to revegetate disturbed areas as quickly as possible. Exposed soils that cannot be permanently stabilized should be temporary seeded if work is not scheduled for at least 14 calendar days. Annual grasses which are quick to germinate such as oats or wheat, should be seeded and mulched to provide prompt, temporary soil cover. Seeding minimizes the area of a construction-site prone to erosion and should be used where the construction operations allow for vegetation to be established. (Metropolitan Council, 2001)

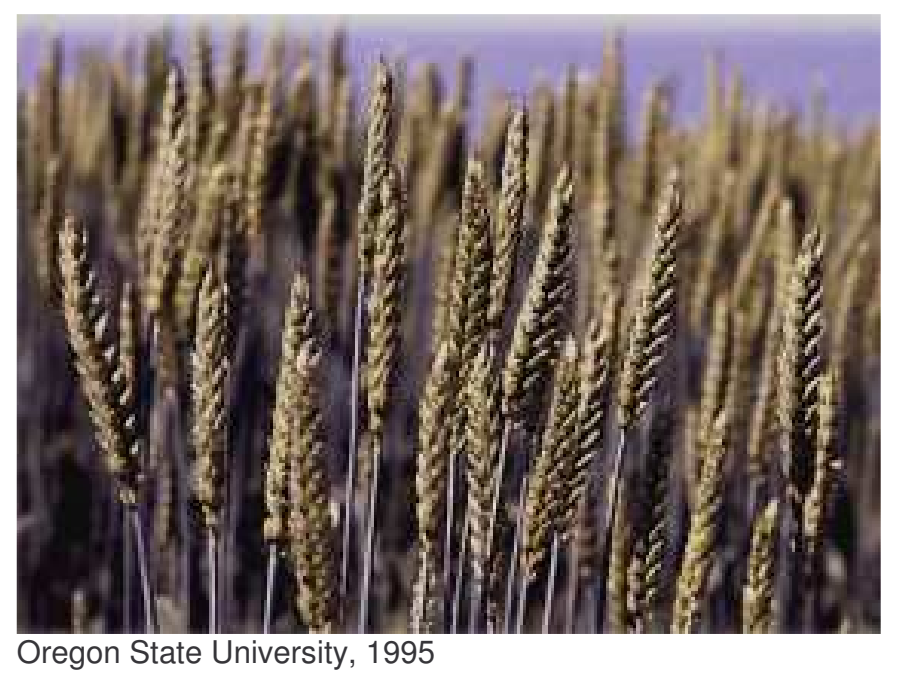

\section{References:}

Metropolitan Council, 2001. Minnesota Urban Small Sites BMP Manual, Stormwater Best Management Practices for Cold Climates. Metropolitan Council Environmental Services. http://www.metrocouncil.org/environment/Watershed/BMP/manual.htm

Oregon State University, 1995. National Forage \& Grasslands Curriculum - Grasses Lecture Topic. Oregon State University, Corvallis, Oregon. http://forages.oregonstate.edu/nfgc/topics.cfm?ID $=90$ 
Native Seeding - Temporary 
INDIANA DEPARTMENT OF TRANSPORTATION
Stormwater Quality Best Management Practices
Construction Sites
Temoorary Slope Drain

\section{When to use:}

- Where cut or fill height exceeds 10 feet prior to the installation of permanent stormwater drainage structures.

- Can be used during embankment construction by continually adding sections to the top of the pipe as the height of the embankment increases

\section{Advantages:}

- Reduces soil exposure to erosive forces.

- Relatively inexpensive to install

\section{Limitations:}

- Inadequate pipe inlet capacity leads to failure from overtopping

- Physical obstructions substantially reduce the effectiveness of the drain

- Can be damaged by vehicular traffic

- Construction equipment and vehicular traffic must be rerouted around slope drains

\section{Description:}

Temporary slope drains are surface water diversions that involve the intentional redirection of runoff or streams in order to direct stabilized off-site runoff around onsite control measures or to direct turbid water to a treatment measure. A temporary slope drain is a flexible conduit extending the length of a disturbed slope and serving as a temporary outlet for a diversion. Temporary slope drains convey runoff without causing erosion on or at the bottom of the slope. This practice is a temporary measure used during grading operations until permanent drainage structures are installed and until slopes are permanently stabilized. They are typically used for less than 2 years. (EPA, 2000)

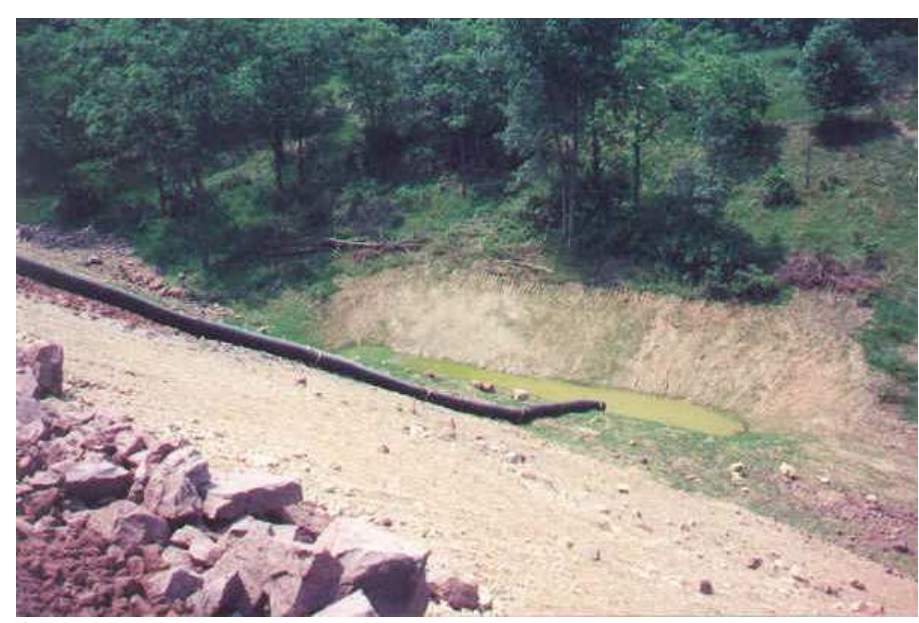

Cacapone, 2001

BMP Type:

Installation Cost:

Maintenance Effort:

Runoff Rate Control:

Runoff Volume Control: No
Erosion Control

Linear

Varies

Medium

No 


\section{Temporary Slope Drain}

\section{Drawings:}

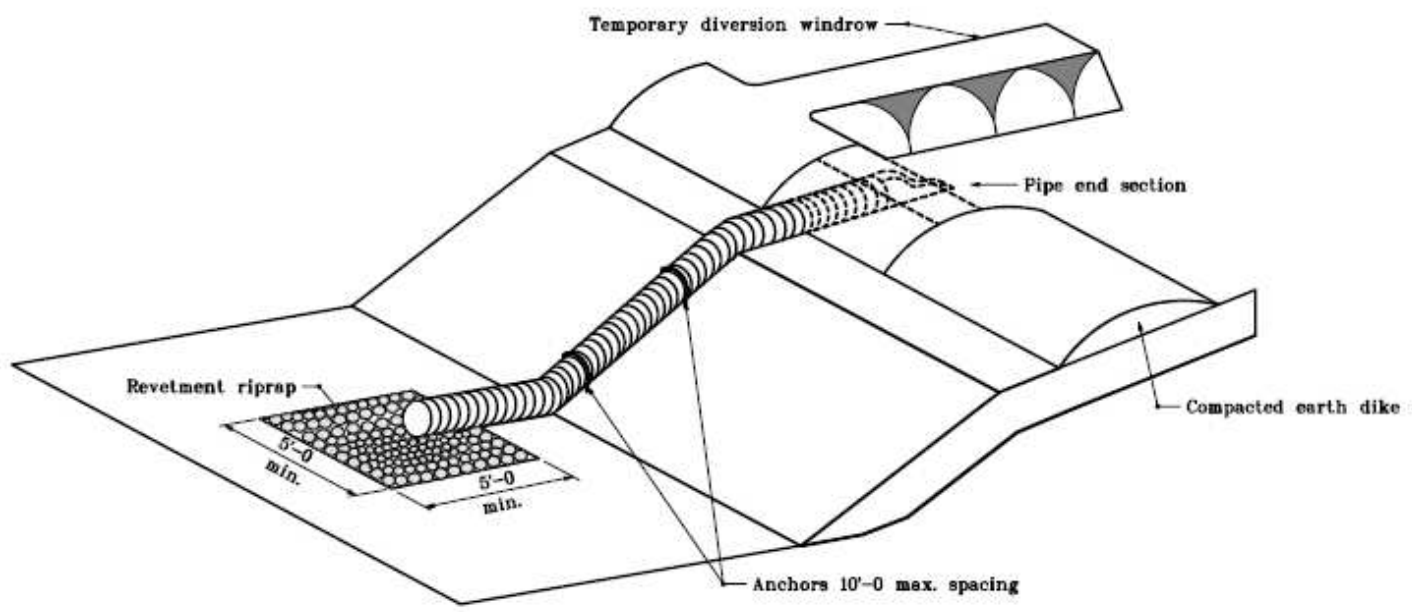

Figure 1: Temporary Slope Drain - Isometric View (INDOT, 2005, Standard Drawings)

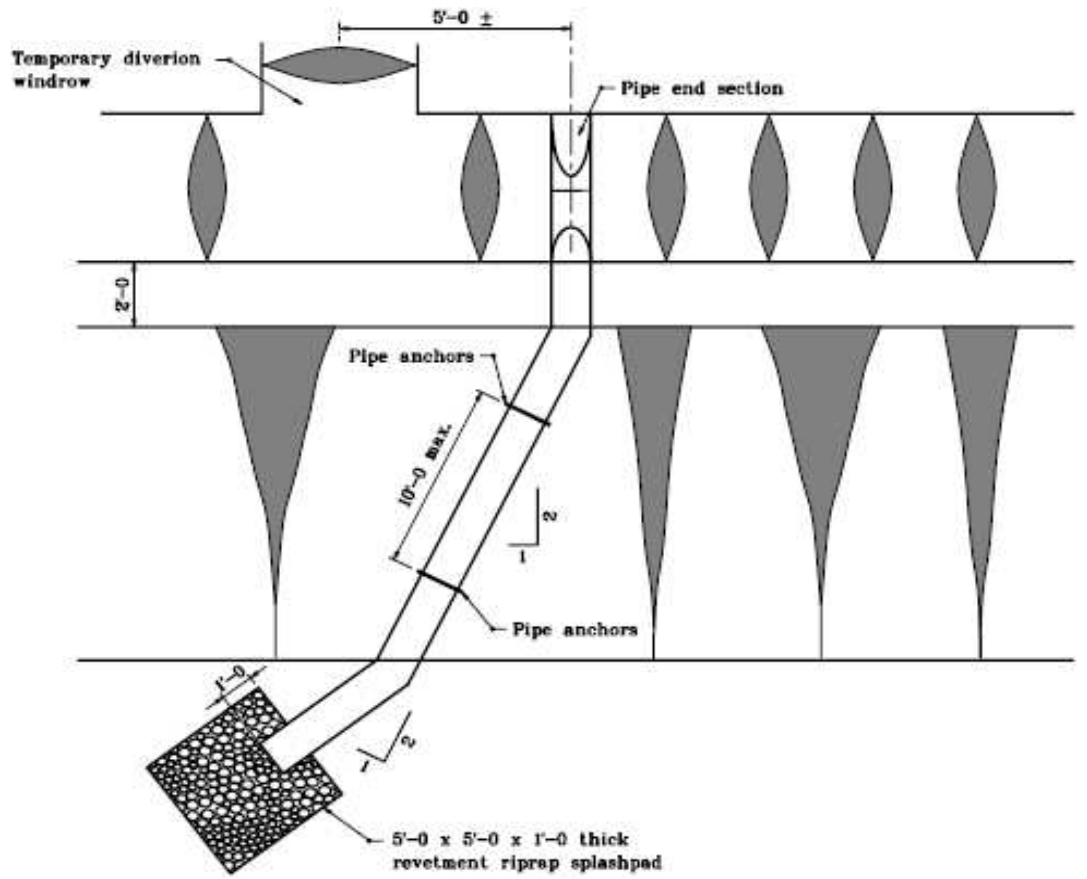

Figure 2: Temporary Slope Drain - Plan View (INDOT, 2005, Standard Drawings)

12 " dia. zinc coated corrugated steel or polyethylene drainage pipe (non-perforated)

Anchors at $10^{\prime}-0$ max. spacing for polyethylene piupe

$$
\begin{array}{r}
4^{\prime}-0 \\
\min .
\end{array}
$$

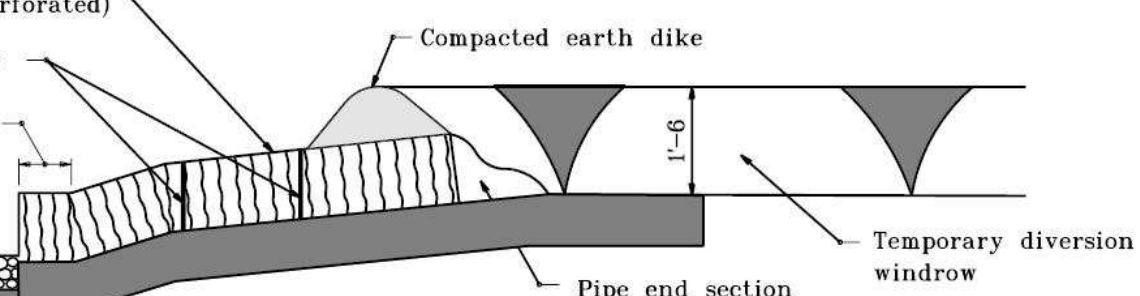

in.

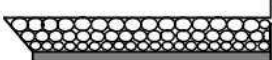

Pipe end section windrow

Figure 3: Temporary Slope Drain - Profile View 


\section{Temporary Slope Drain}

(INDOT, 2005, Standard Drawings)

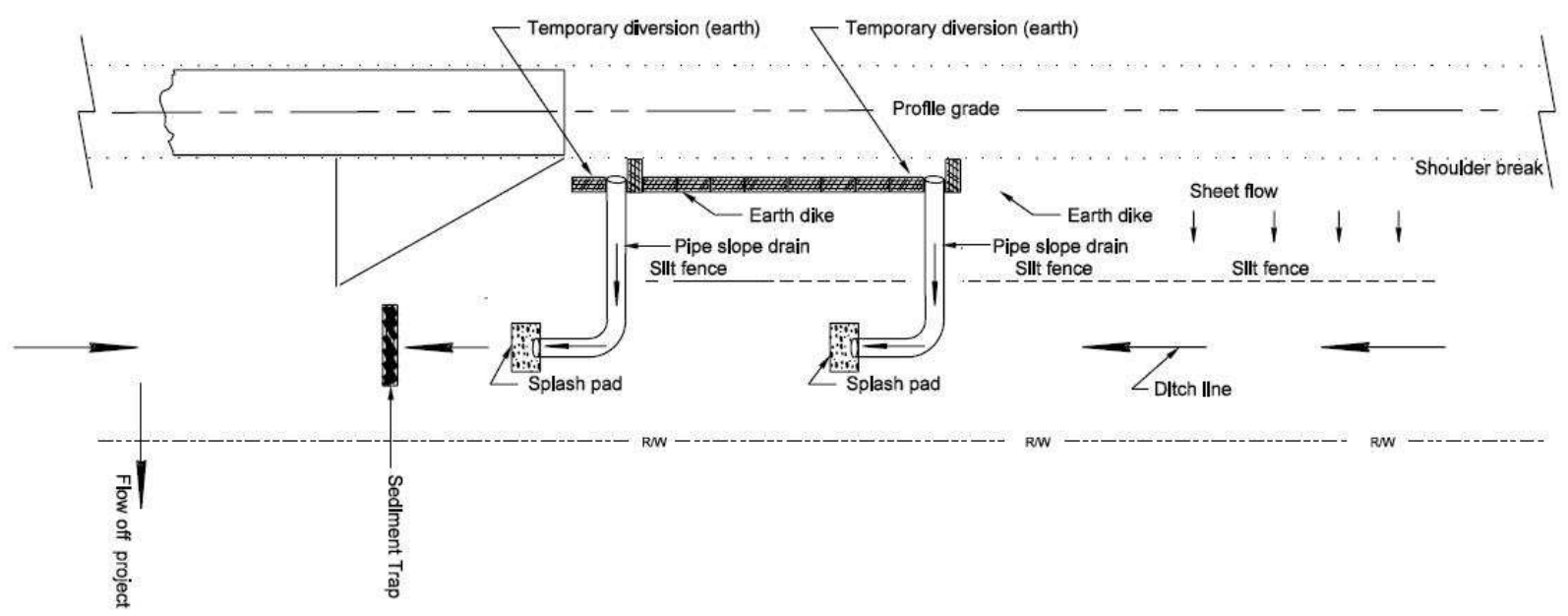

Figure 4: Temporary Slope Drain System - Plan View (INDOT, 2005, Design Manual)

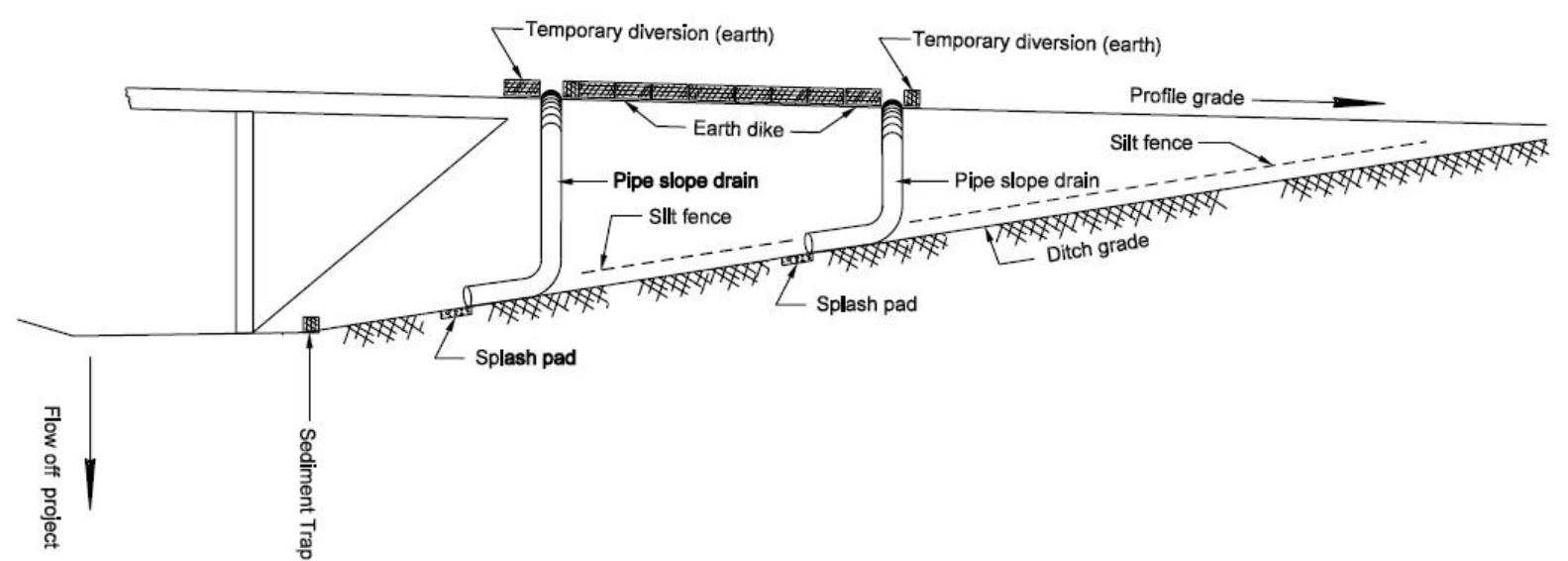

Figure 5: Temporary Slope Drain System - Profile View (INDOT, 2005, Design Manual)

\section{Reference:}

EPA, 2000. EPA's Storm Water Phase II Menu of Best Management Practices. Environmental Protection Agency, National Pollution Discharge Elimination System, Stormwater Team. http://cfpub2.epa.gov/NPDES/stormwater/menuofbmps/pdf/small_files/main.pdf

INDOT, 2005. Indiana Department of Transportation Design Manual, Part 4, Chapter 37 - Temporary Erosion and Sediment Control. Indiana Department of Transportation, Division of Design. http://www.in.gov/dot/div/contracts/standards/dm/Part\%204\%20Vol.\%202/Ch\%2037/ch37.htm

Capacone, 2001, Capacone, Volume 11, Number 1, Capacone Institute, December 2001. http://cacaponinstitute.org/PDF/Newsletterdec2001.PDF 
INDIANA DEPARTMENT OF TRANSPORTATION
Stormwater Quality Best Management Practices
Construction Sites
Intercegtor Berm

\section{When to use:}

- Along construction perimeters to keep construction runoff separate from off-site runoff.

- Within construction sites to control runoff patterns to minimize erosion or to route to treatment

\section{Advantages:}

- Keeps clean and dirty water separate to reduce volume of water that must be treated.

- Inexpensive to construct

$\begin{array}{ll}\text { BMP Type: } & \begin{array}{l}\text { Erosion Control } \\ \text { Linear }\end{array} \\ & \$ 160-\$ 500 \text { / } \\ \text { Installation Cost: } & 100 \mathrm{ft} \\ \text { Maintenance Effort: } & \text { Medium } \\ \text { Runoff Rate Control: } & \text { No } \\ \text { Runoff Volume Control: } & \text { No }\end{array}$

\section{Limitations:}

- Do not have any pollutant removal capability

- Concentrated runoff in the channel or ditch has increased erosion potential

\section{Description:}

Interceptor berms are surface water diversion measures that involve the intentional redirection of runoff or streams in order to minimize contact between surface water and bare soil or to direct turbid water to a treatment measure. Diversion berms can be installed alone or in combination with a channel bypass. When located on the upslope side of a site, diversion berms help to prevent off-site runoff from entering a disturbed construction site. Interceptor berms can be located on the downslope side of a construction site to divert sediment-laden runoff to onsite sediment trapping devices, preventing movement of soil laden water to adjacent undisturbed areas. (EPA, 2000)

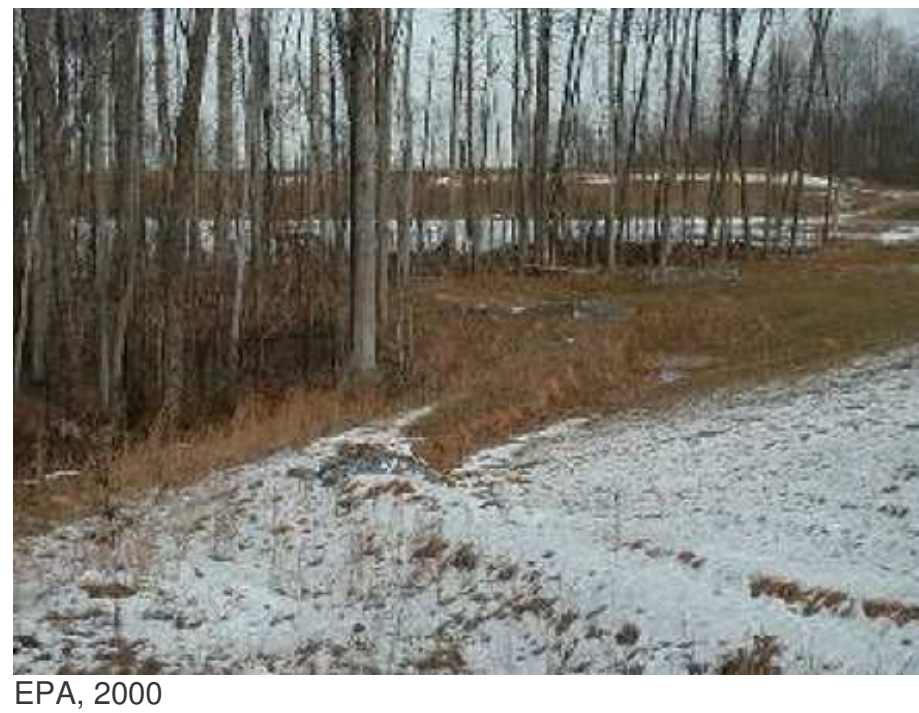




\section{Interceptor Berm}

Drawings:

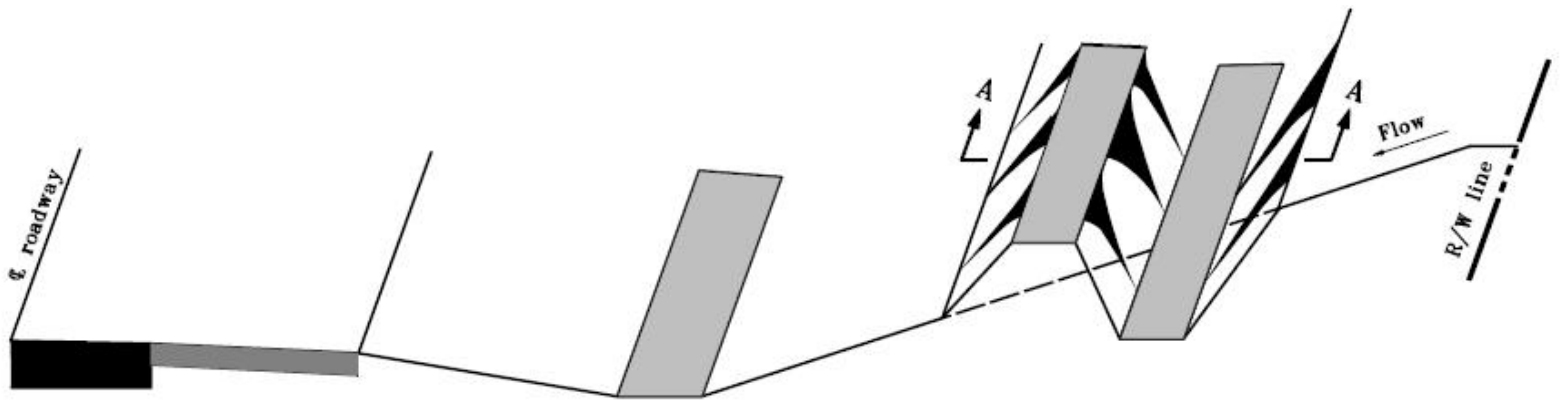

Figure 1: Interceptor Berm and Ditch in a Cut Section

(Intercepts runoff from undisturbed off site areas and diverts around work site)

(INDOT, 2005, Standard Drawing)

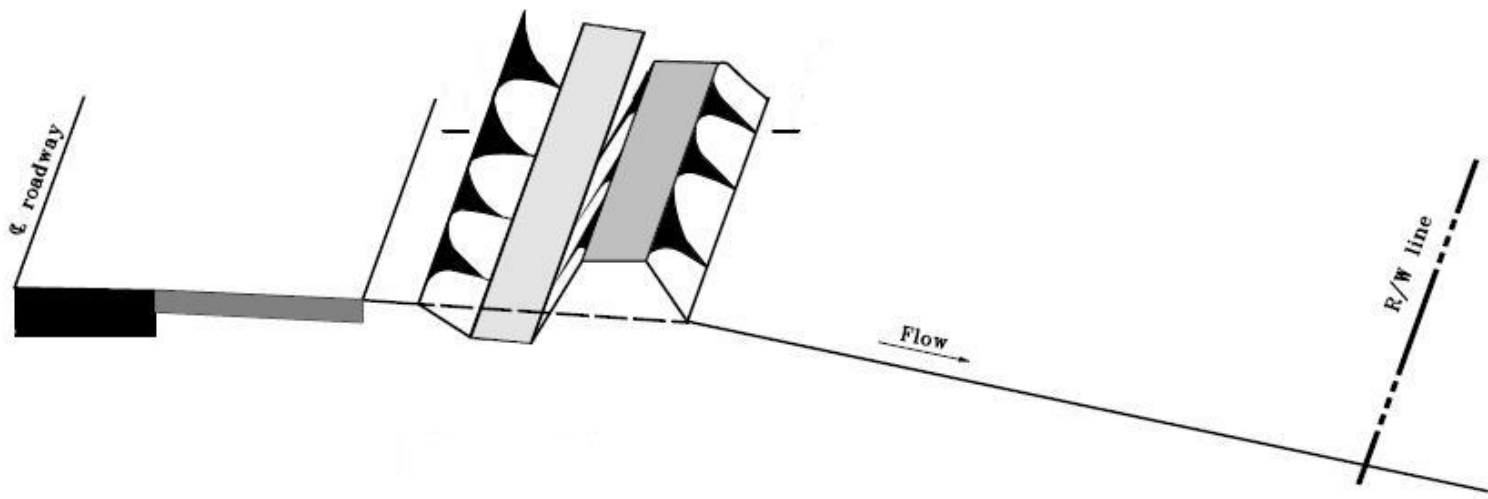

Figure 2: Interceptor Berm and Ditch in a Fill Section

(Intercepts sediment laden runoff and diverts to sediment trapping device and protects slope)

(INDOT, 2005, Standard Drawing)

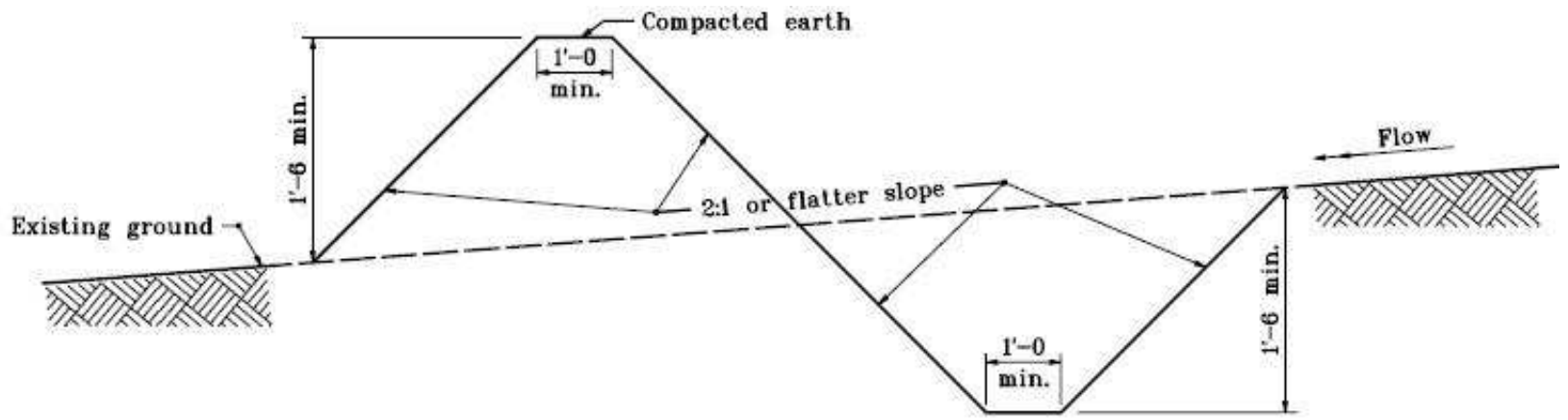

Figure 3: Interceptor Berm and Ditch Cross Section A-A

(INDOT, 2005, Standard Drawing) 


\section{Interceptor Berm}

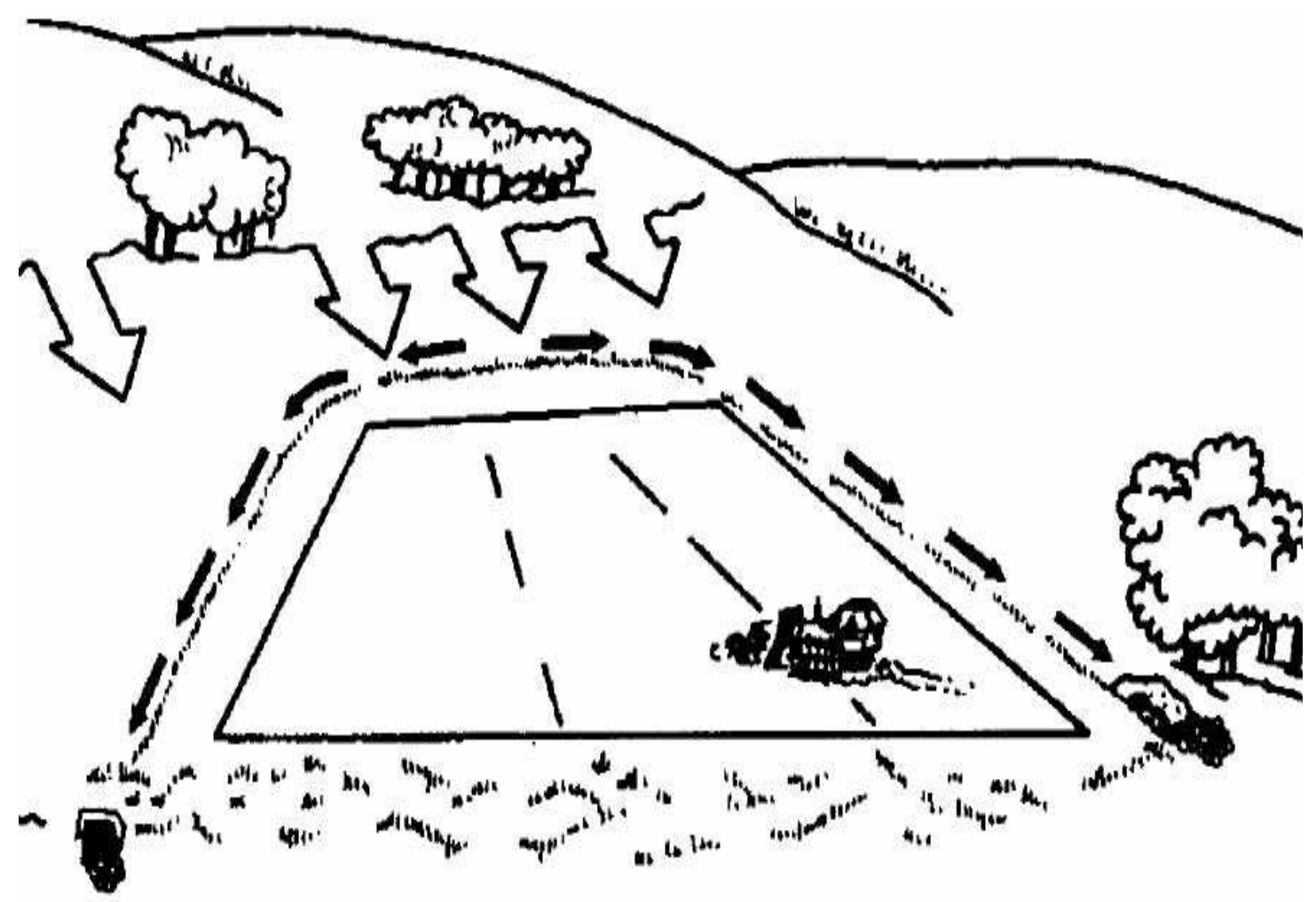

Figure 4: Example of Interceptor Berm to Divert Runoff from Off-site

(Metropolitan Council, 2001)

\section{Reference:}

EPA, 2000. EPA's Storm Water Phase II Menu of Best Management Practices. Environmental Protection Agency, National Pollution Discharge Elimination System, Stormwater Team. http://cfpub2.epa.gov/NPDES/stormwater/menuofbmps/pdf/small_files/main.pdf

INDOT, 2005. Indiana Department of Transportation Standard Drawings - Sections 100 through 300. Effective Sept. 2005. Indiana Department of Transportation, Division of Design.

http://www.in.gov/dot/div/contracts/standards/drawings/sep05/e/sep1to3.htm

Metropolitan Council, 2001. Minnesota Urban Small Sites BMP Manual, Stormwater Best Management Practices for Cold Climates. Metropolitan Council Environmental Services. http://www.metrocouncil.org/environment/Watershed/BMP/manual.htm 
DNDIANA DEPARTMENT OF TRANSPORTATION
Stormwater Quality Best Management Practices
Construction Sites
Channe BV Bas

\section{When to use:}

- For small structure and culvert replacement

- Bridge repair sites

- In perennial or intermittent streams

- During the dry season

\section{Advantages:}

- Keeps clean and dirty water separate to reduce volume of water that must be treated.

- Allows for work in the channel with minimum wildlife disturbance

\section{Limitations:}

- Larger streams or rivers require more involved, engineered solutions

- Fabric lined channels may cause thermal pollution in the summer months

- May require a substantial work area

\section{Description:}

A channel bypass is a surface water diversion that involves the intentional redirection of runoff or streams in order to minimize contact between surface water and bare soil or to direct turbid water to a treatment measure. A channel bypass is a method of diverting flow of a stream to a temporary alternate route during construction. A channel bypass is typically constructed adjacent to the work area and is lined with geotextile to reduce erosion of the diversion channel. (NCDOT, 2003)

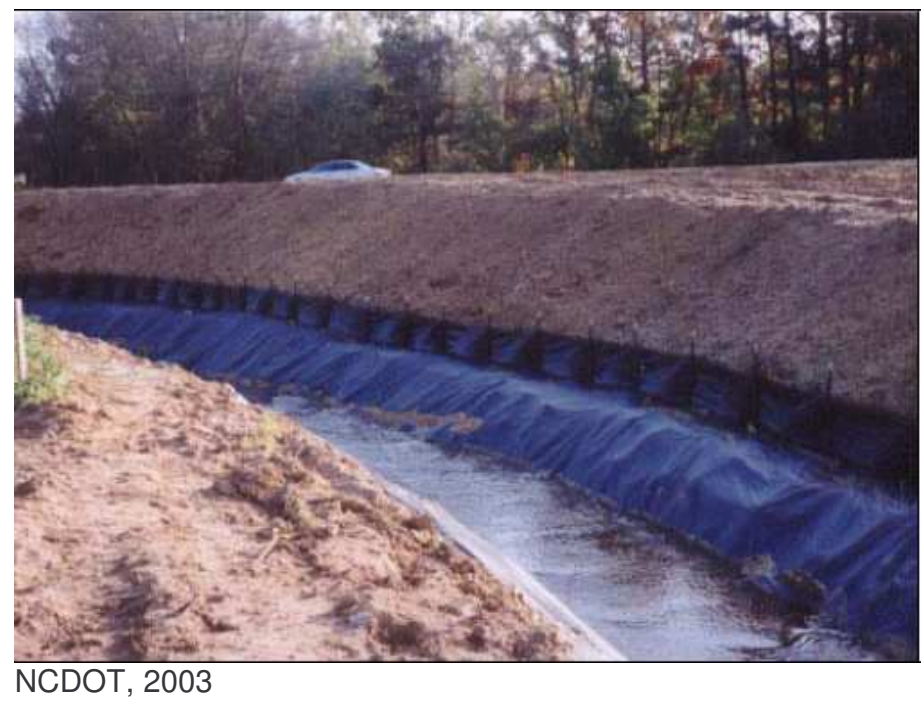

\section{References:}

NCDOT, 2003. Best Management Practices for Construction and Maintenance Activities. North Carolina Department of Transportation, Division of Highways, Highway Operations.

http://www.ncdot.org/doh/operations/BMP_Manual/download/BMP_Manual.pdf 


\section{Channel Bypass}


INDIANA DEPARTMENT OF TRANSPORTATION
Stormwater Quality Best Management Practices
Construction Sites

\section{When to use:}

- When performing work on a stream bank or shoreline in a small localized area.

- When the repair or construction activities will not require an extended period of time to complete.

- Should NOT be used across flowing streams

- In streams with flows of less than $5 \mathrm{ft} / \mathrm{sec}$

\section{Advantages:}

- Often most practical option to protect work in waterway

\section{Limitations:}

- Improper anchoring leads to ineffective control

- Can require frequent repositioning

- Can not be used along fast flowing waterways, (>5 ft/s) where bank stabilization methods are often required

\section{Description:}

Turbidity curtain barriers are useful when working on the bank of an existing waterbody or in the rarer instance where the proposed work encroaches into the waterbody. The purpose of a turbidity curtain is to prevent the flow and/or washing of disturbed debris into a water source: stream, river, pool, lake or reservoir. In essence, a turbidity curtain is a floating silt fence. A turbidity curtain should not be used as a dam. It will not "hold back" the water flow of a river or stream, but it will inhibit sediment laden water from entering the main waterway.

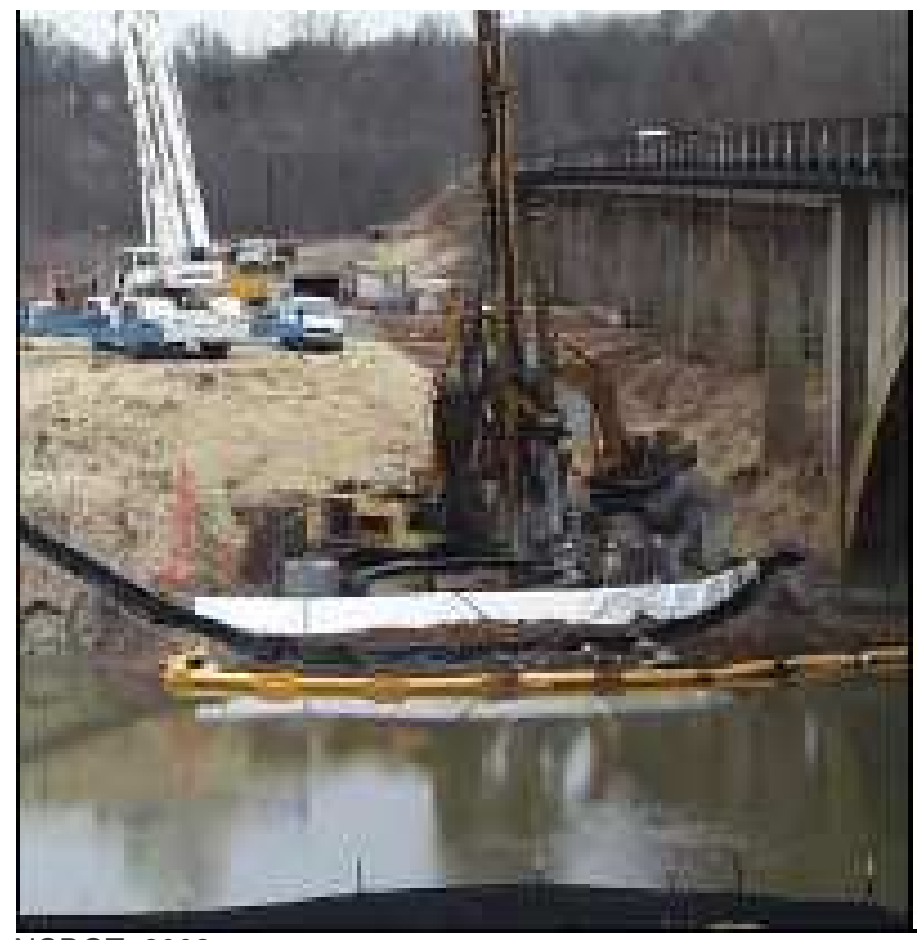




\section{Turbidity Curtain}

\section{Drawings:}

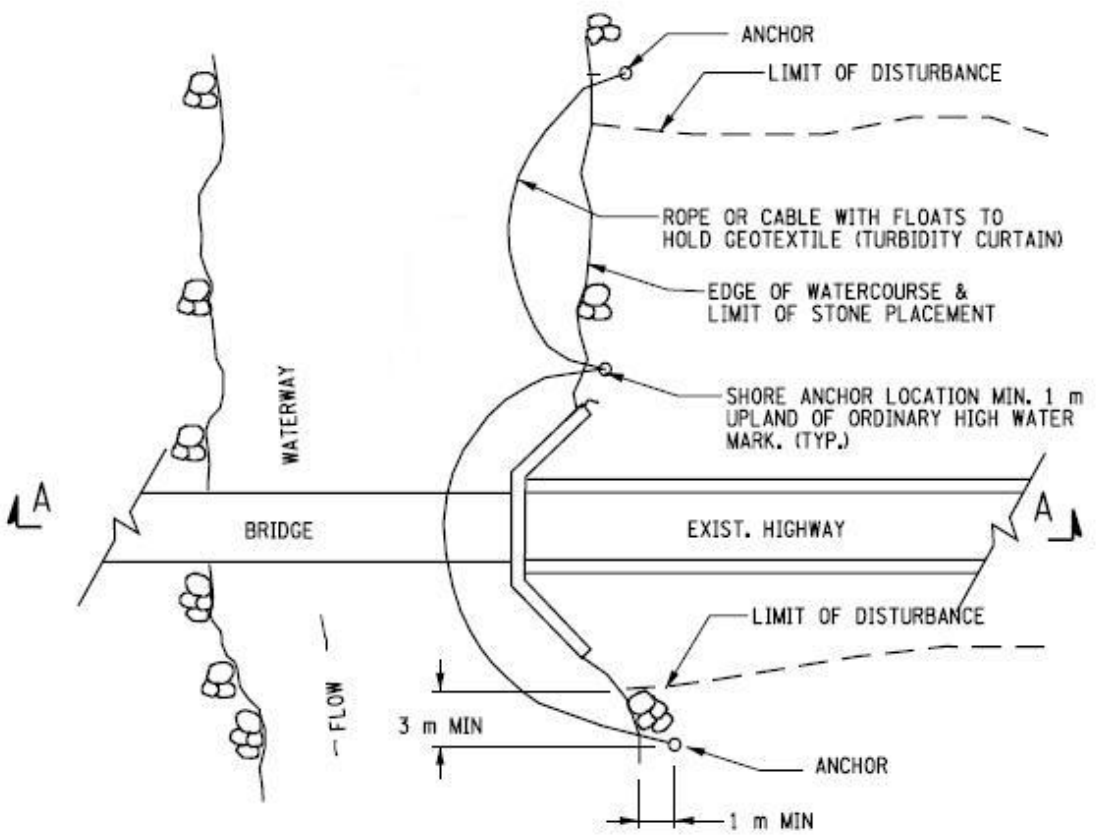

Figure 1: Curtain Installation, Plan View

(NYDOT, 2002)

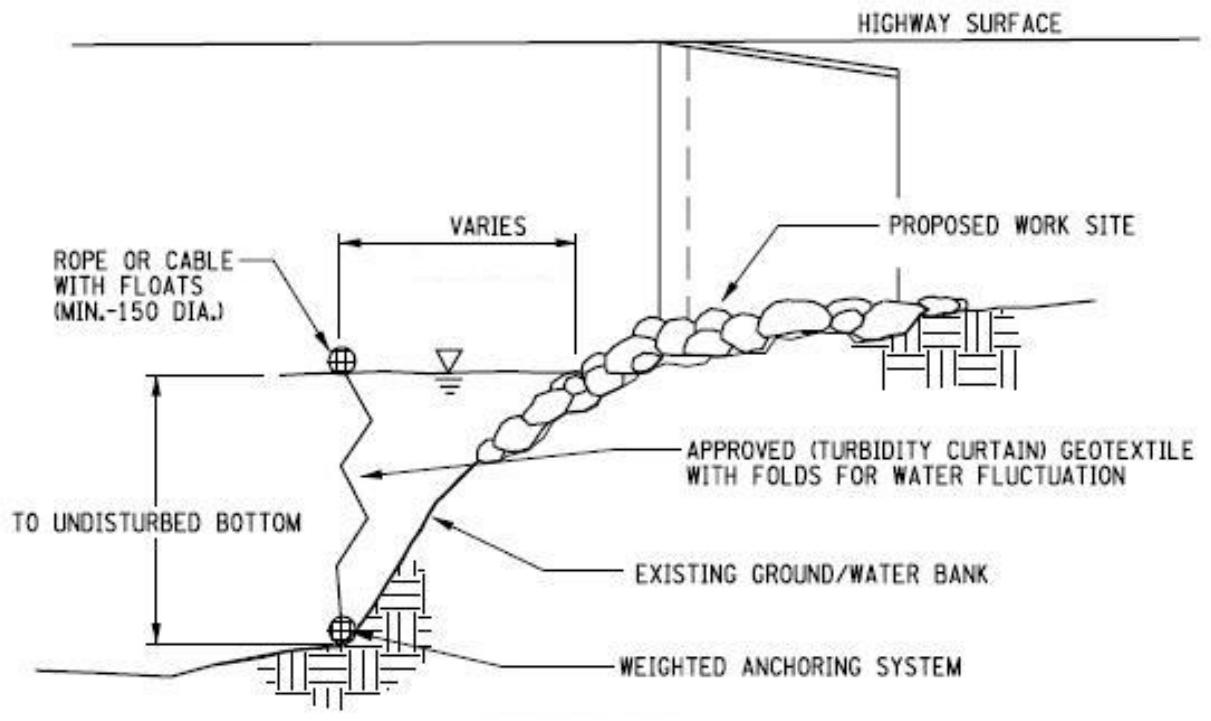

Figure 2: Cross Sectional View A-A

\section{References:}

(NYDOT, 2002)

NYDOT, 2002. Soil Erosion and Sediment Control Standard Sheet M209-8 - Turbidity Curtain. State of New York Department of Transportation.

http://www.dot.state.ny.us/caddinfo/design/stdsheets/standardpdf/m209-8.pdf

NCDOT, 2003. Best Management Practices for Construction and Maintenance Activities. North Carolina Department of Transportation, Division of Highways, Highway Operations.

http://www.ncdot.org/doh/operations/BMP_Manual/download/BMP_Manual.pdf 


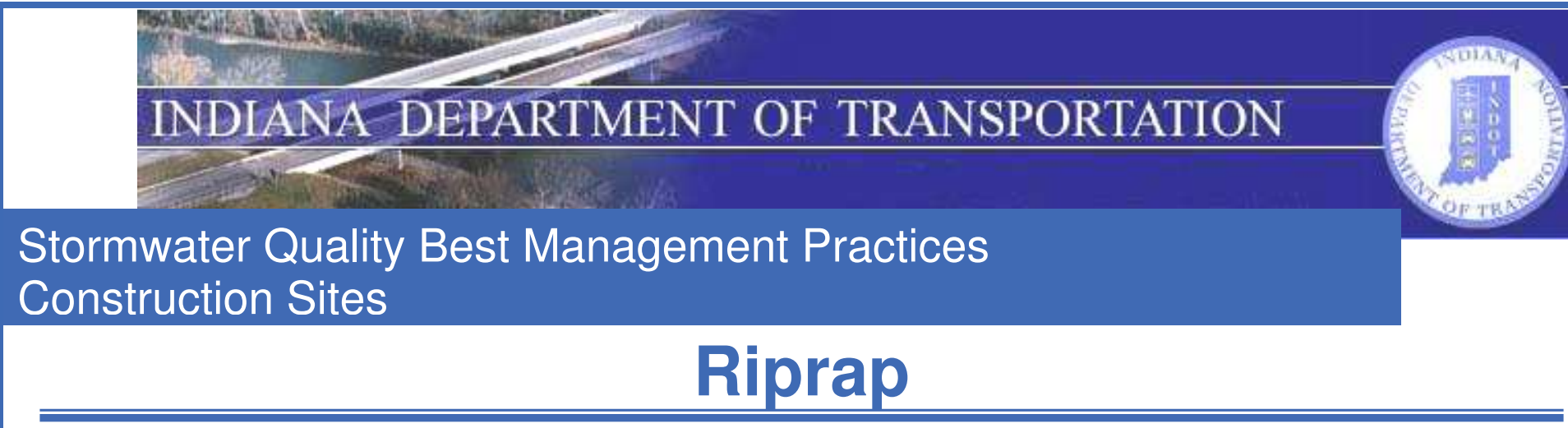

\section{When to use:}

- Around the inlets and outlet of pipes, culverts, and paved ditches.

\section{Advantages:}

- Can prevent virtually all erosion from the protected area.

- Reduces downstream erosive forces

\section{Limitations:}

- Should not be used on slopes steeper than 2:1.

- Potential hazard in the clear zone

\section{Description:}

Riprap can be used to provide permanent and temporary erosion protection on small construction sites in several ways. Three such methods are inlet and outlet protection, temporary diversion structures, and permanent diversion structures. Pipe inlet and outlet protection is a protective armor for the immediate area around the inlet and outlet of a pipe or culvert to protect it and the receiving channel from scour and deterioration. This practice applies to culverts and principal spillways. Riprap should not be used in areas where native vegetation would be effective. However, riprap should be considered in areas of potential high velocity and areas below the ordinary high water level where vegetation will not easily establish.

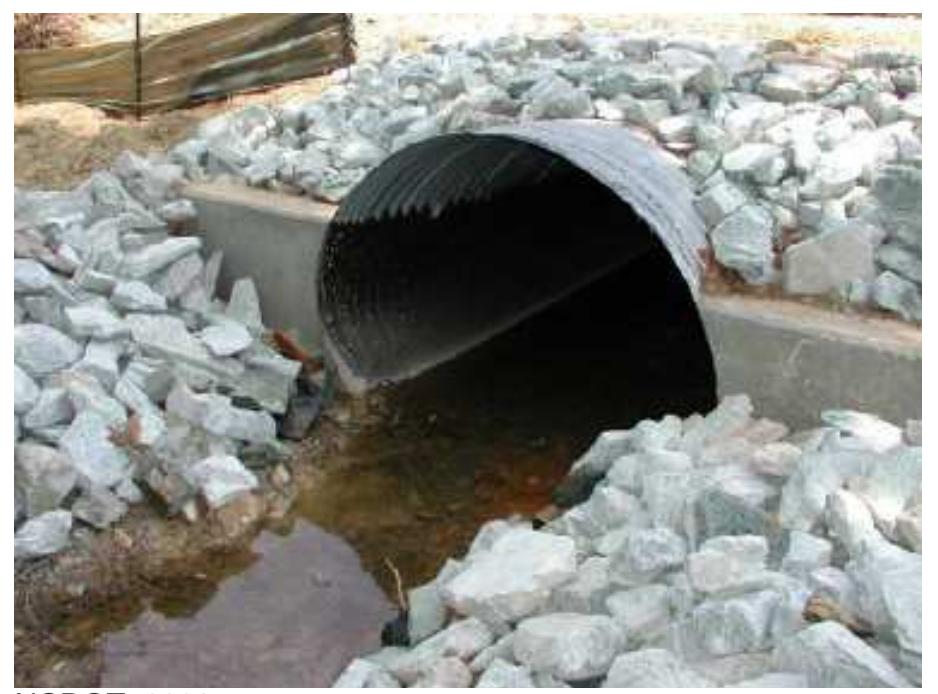

NCDOT, 2003

\section{References:}

NCDOT, 2003. Best Management Practices for Construction and Maintenance Activities. North Carolina Department of Transportation, Division of Highways, Highway Operations. http://www.ncdot.org/doh/operations/BMP_Manual/download/BMP_Manual.pdf 
INDIANA DEPARTMENT OF TRANSPORTATION
Stormwater Quality Best Management Practices
Construction Sites
Vehicle Tracking Pad

\section{When to use:}

- At all points of egress to public roads

- Where construction vehicles leave active construction areas onto surfaces where runoff is not checked by sediment controls

\section{Advantages:}

- Cost-effective

- Highly effective for sediment control

\section{Limitations:}

- Can require intensive maintenance

- Stone can become quickly saturated under muddy conditions

\section{Description:}

The vehicle tracking pad is intended to be the final perimeter control at the construction site. The base should consist of stable compacted aggregate to minimize settling. Above the base, aggregate should be placed that is large enough to cause exiting vehicles to move in such a way to dislodge sediment. This is usually accomplished when the aggregate size of the upper stone layer ranges in size from 3 to 6 inches in diameter. A corrugated metal plate, known as a shaker plate, can also be incorporated to facilitate sediment removal.

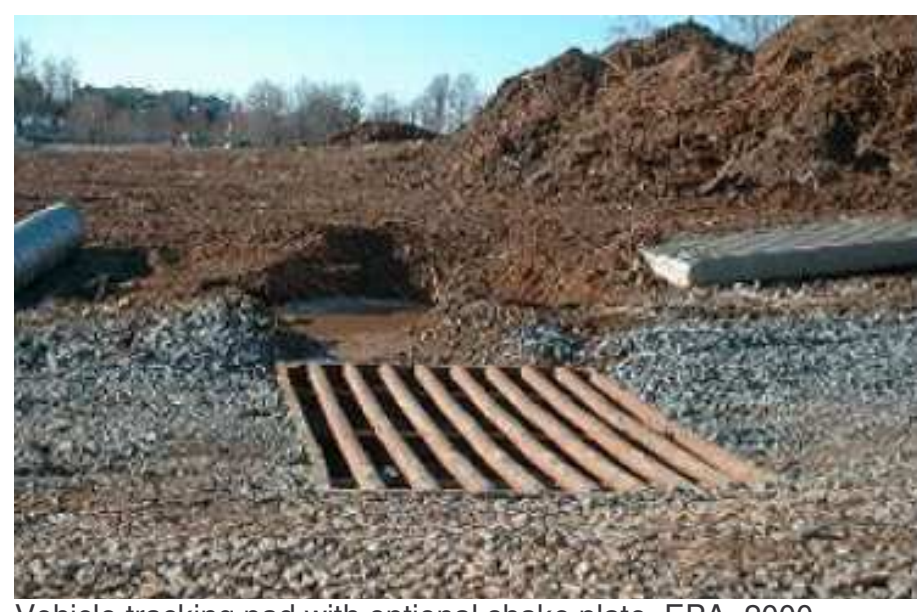

Vehicle tracking pad with optional shake plate, EPA, 2000 


\section{Vehicle Tracking Pad}

\section{Drawings:}

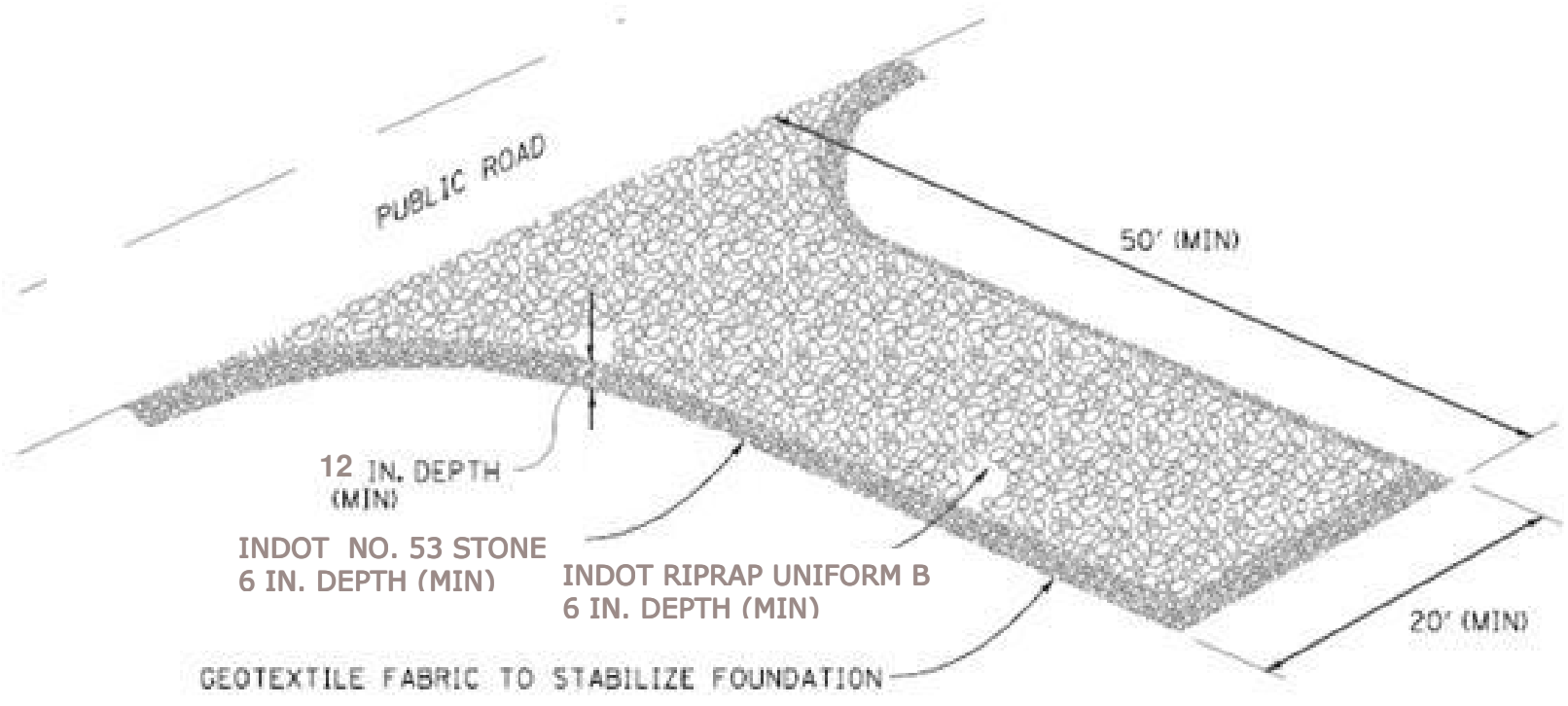

Figure 1: Vehicle Tracking Pad - Isometric View

(CBBEL file)

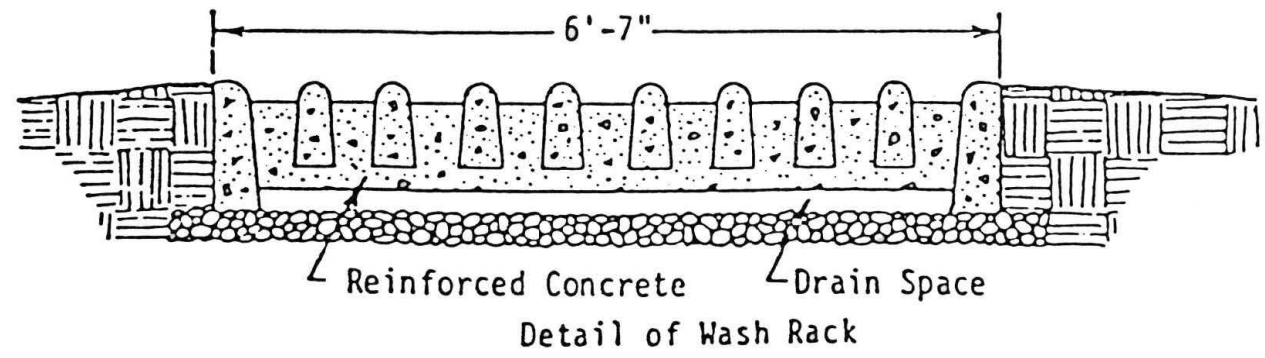

Figure 2: Example of Wash Rack

(Metropolitan Council, 2001)

\section{Reference:}

EPA, 2000. EPA's Storm Water Phase II Menu of Best Management Practices. Environmental Protection Agency, National Pollution Discharge Elimination System, Stormwater Team. http://cfpub2.epa.gov/NPDES/stormwater/menuofbmps/pdf/small_files/main.pdf

Metropolitan Council, 2001. Minnesota Urban Small Sites BMP Manual, Stormwater Best Management Practices for Cold Climates. Metropolitan Council Environmental Services. http://www.metrocouncil.org/environment/Watershed/BMP/manual.htm

North Augusta , 2004. The City of North Augusta Erosion and Sediment Control Manual. City of North Augusta, Stormwater Management Department.

http://www.northaugusta.net/Dept_Serv/Engin_PublicWorks/stormwater/developers.htm 


\section{Silt Fence}

\section{When to use:}

- Around the base of stockpiled erodible material

- Along banks of waterways

- As perimeter protection

- On sites with relatively small drainage areas

- Where runoff will be occurring as low-level shallow flow

\section{Advantages:}

- Cost-effective on smaller sites

- Construction community is already very familiar with use of silt fence

\section{Limitations:}

- High maintenance

- Frequent failure due to improper installation and inadequate maintenance

- Not effective in rocky areas where fence can not be entrenched

- Can not handle concentrated flow

- High winds can present a problem

- Not for use on fill slopes

\section{Description:}

A silt fence is a fabric or wire mesh barrier used to retain sediment from small, sloping disturbed areas by reducing the velocity of sheet flow. Silt fence captures sediment by ponding water to allow deposition on the uphill side. Silt fences consist of a length of geotextile or wire mesh stretched between anchoring posts spaced at regular intervals along the site perimeter. The geotextile should be entrenched in the ground between the support posts. A silt fence is not recommended to divert water; nor is it to be used across a stream, channel, or anywhere that concentrated flow is anticipated (EPA, 2000). Silt fence should be used parallel to contour

elevation lines only. Placing silt fence perpendicular to contour lines can actually increase erosion by concentrating flow along the disturbed embedment trench.

\section{BMP Type:}

Installation Cost:

Maintenance Effort:

Runoff Rate Control:

Runoff Volume Control:
Sediment Control Linear

$\$ 1.00-\$ 3.00 / \mathrm{ft}$

High

Some

No

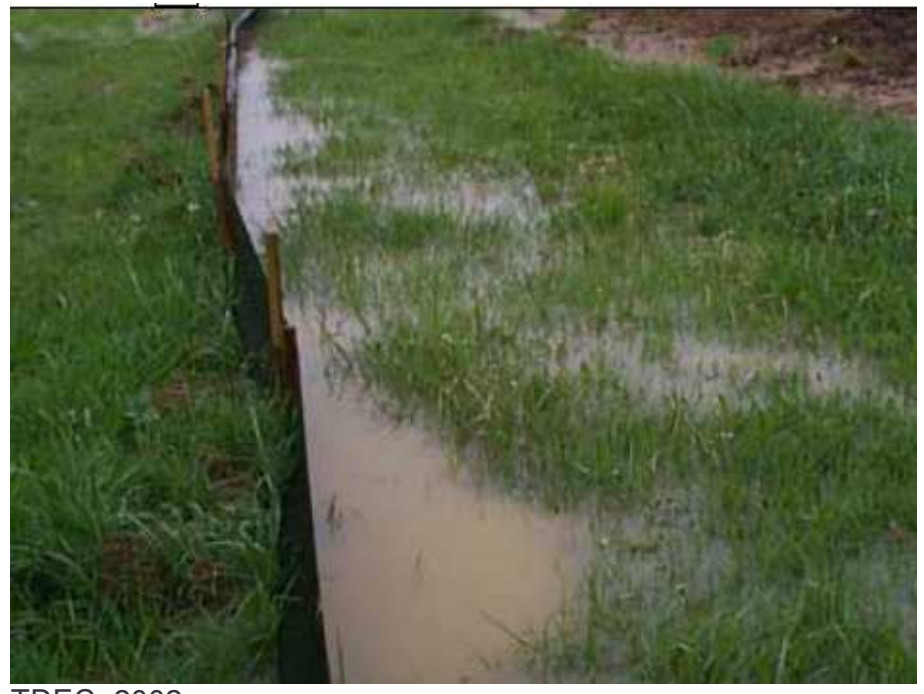

TDEC, 2002 


\section{Silt Fence}

\section{Drawings:}

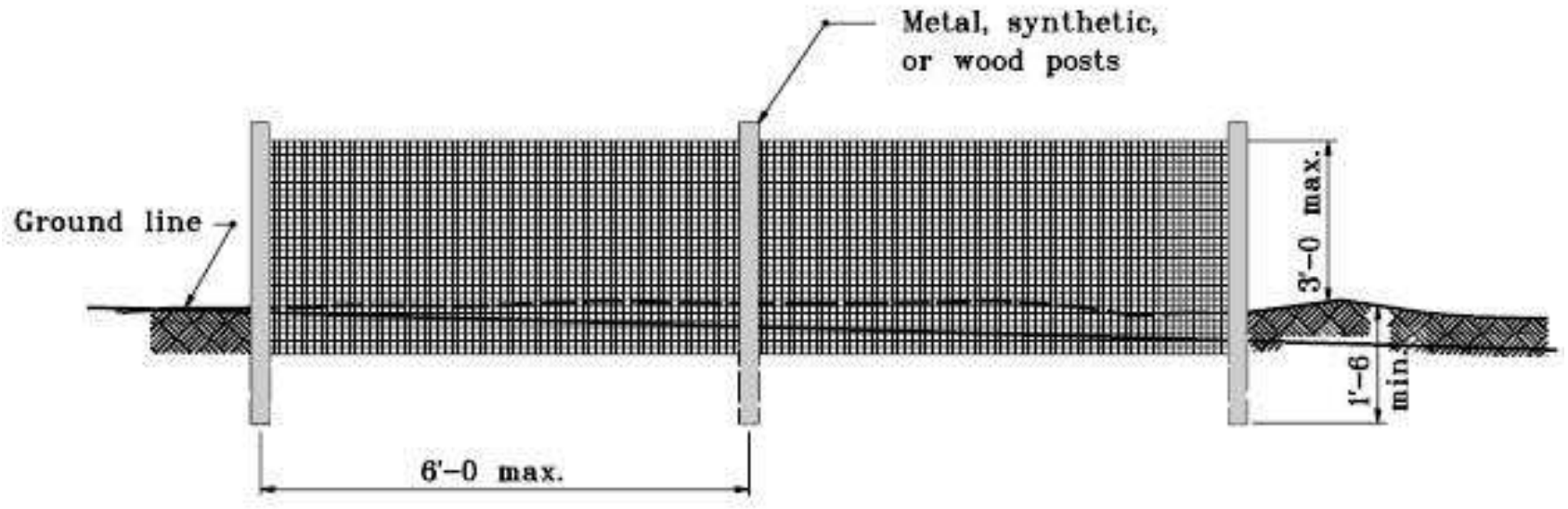

Figure 1: Silt Fence Entrenchment and Dimensions

(INDOT, 2005, Standard Drawings)

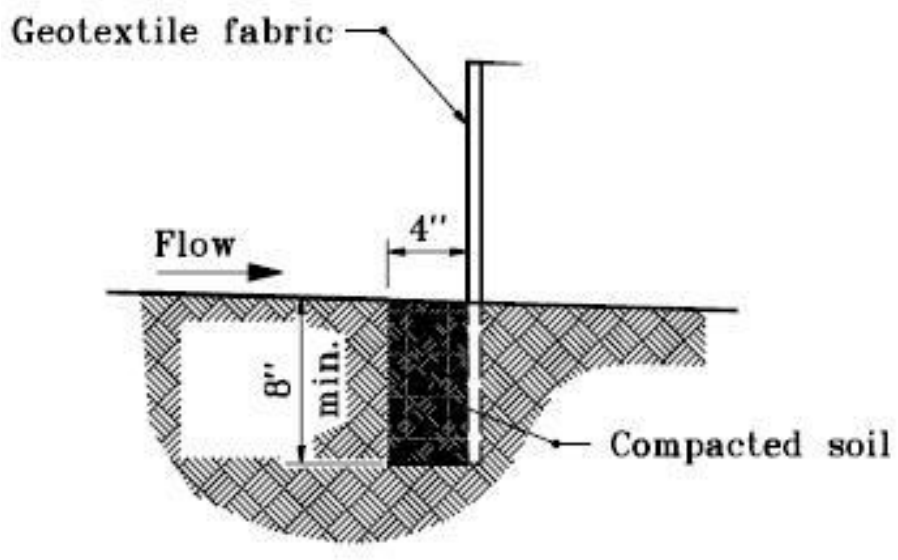

Figure 2: Embedment Detail (INDOT, 2005, Standard Drawings)

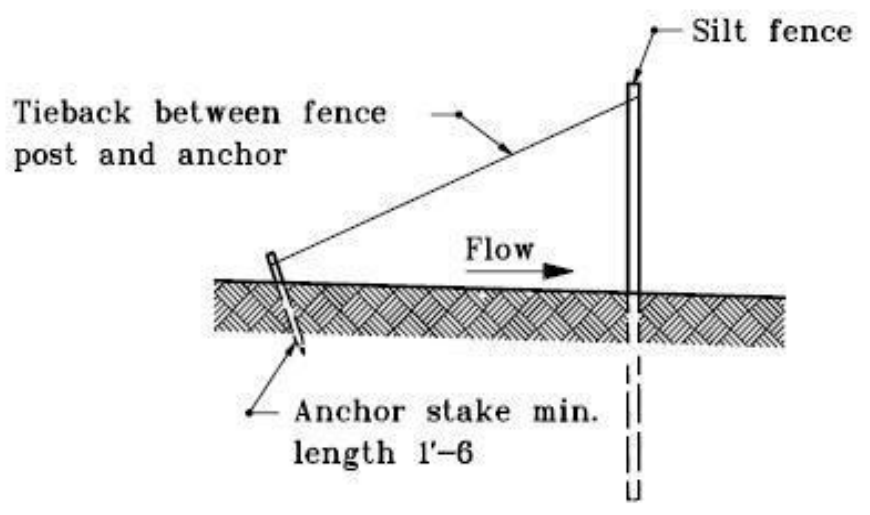

Figure 3: Tieback Detail

(INDOT, 2005, Standard Drawings)

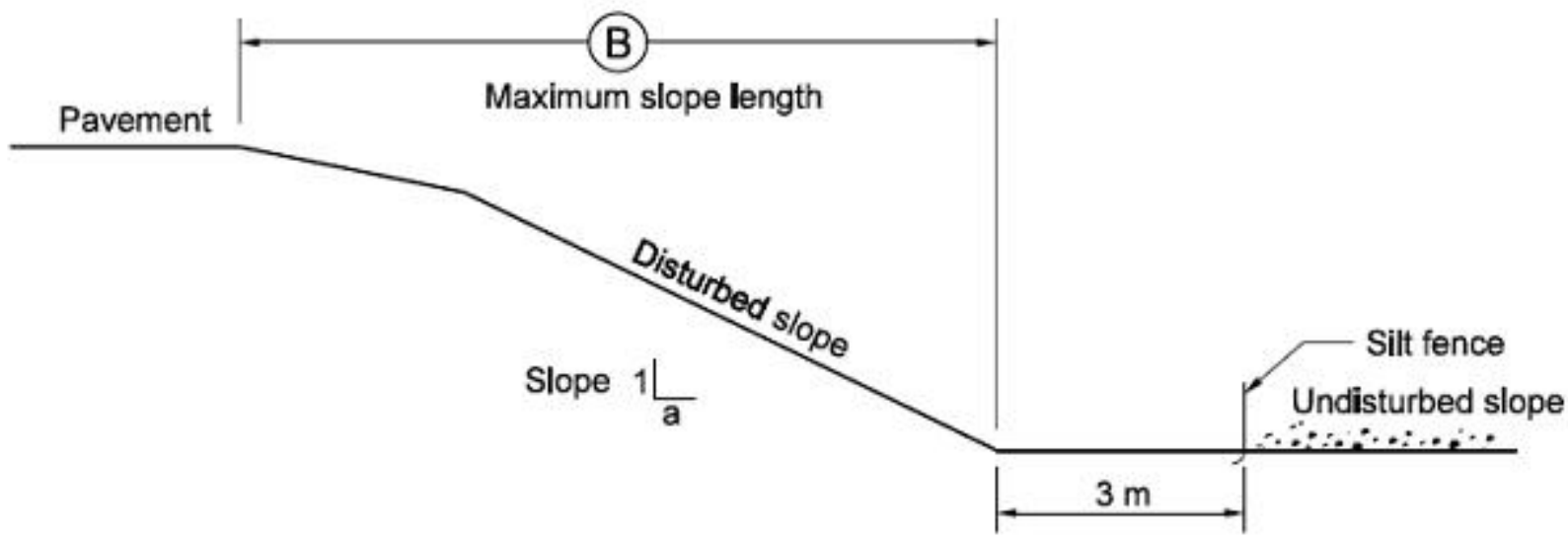

Figure 4: Silt Fence Placement Relative to R/W Line (Modified from INDOT, 2006) 


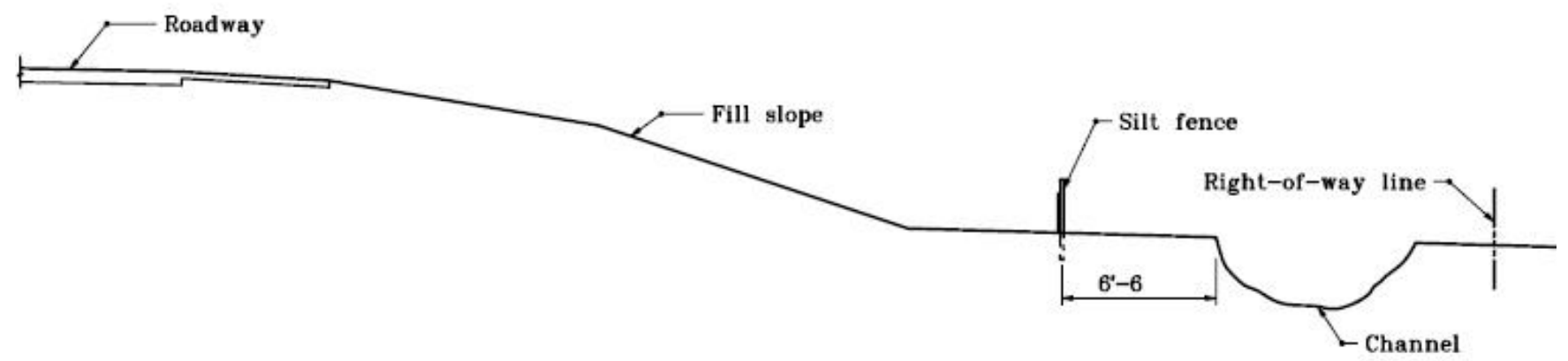

Figure 5: Silt Fence Placement with Channel in R/W (INDOT, 2005, Standard Drawings)

\section{Reference:}

EPA, 2000. EPA's Storm Water Phase II Menu of Best Management Practices. Environmental Protection Agency, National Pollution Discharge Elimination System, Stormwater Team. http://cfpub2.epa.gov/NPDES/stormwater/menuofbmps/pdf/small_files/main.pdf

INDOT, 2005. Indiana Department of Transportation Standard Drawings - Sections 100 through 300. Effective Sept. 2005. Indiana Department of Transportation, Division of Design.

http://www.in.gov/dot/div/contracts/standards/drawings/sep05/e/sep1to3.htm

INDOT, 2006. Indiana Department of Transportation Standard Specifications - Section 200. Effective Sept. 2005. Indiana Department of Transportation, Division of Design.

http://www.in.gov/dot/div/contracts/standards/book/sep06/2-2006.pdf 
INDIANA DEPARTMENT OF TRANSPORTATION
Stormwater Quality Best Management Practices
Construction Sites

\section{When to use:}

- On existing drop inlets, bridge deck drains, and curb inlets for rehab or reconstruction projects

- Following installation of new inlets

- For drainage areas no greater than 1 acre per inlet

- For relatively low-sediment, low-volume flows

\section{Advantages:}

- Allows for continuous use of storm drain system

\section{Limitations:}

- Should be used in conjunction with other measures

- Require frequent maintenance

- Only practical for low-sediment, low-volume flows

- Can cause erosion to unprotected areas if clogged

- Designer should evaluate bypass flow path under the condition of fully blocked/clogged inlet

\section{Description:}

Storm drain inlet protection measures are controls that help prevent soil and debris from site erosion from entering storm drain drop or curb inlets. Typically, these measures are temporary controls that are implemented prior to large-scale disturbance of the surrounding site. These controls are advantageous because their implementation allows storm drains to be used during construction activities (EPA, 2000). Inlet protection is often the last opportunity to minimize sediment impact to a receiving water body (WSDOT, 2004). Inlet protection can cause inadvertent flooding of adjacent areas if not properly installed.
BMP Type:

Installation Cost:

Maintenance Effort:

Runoff Rate Control:

Runoff Volume Control:
Sediment Control

Linear

$\$ 50$ to $\$ 150 /$ inlet

High

No

No

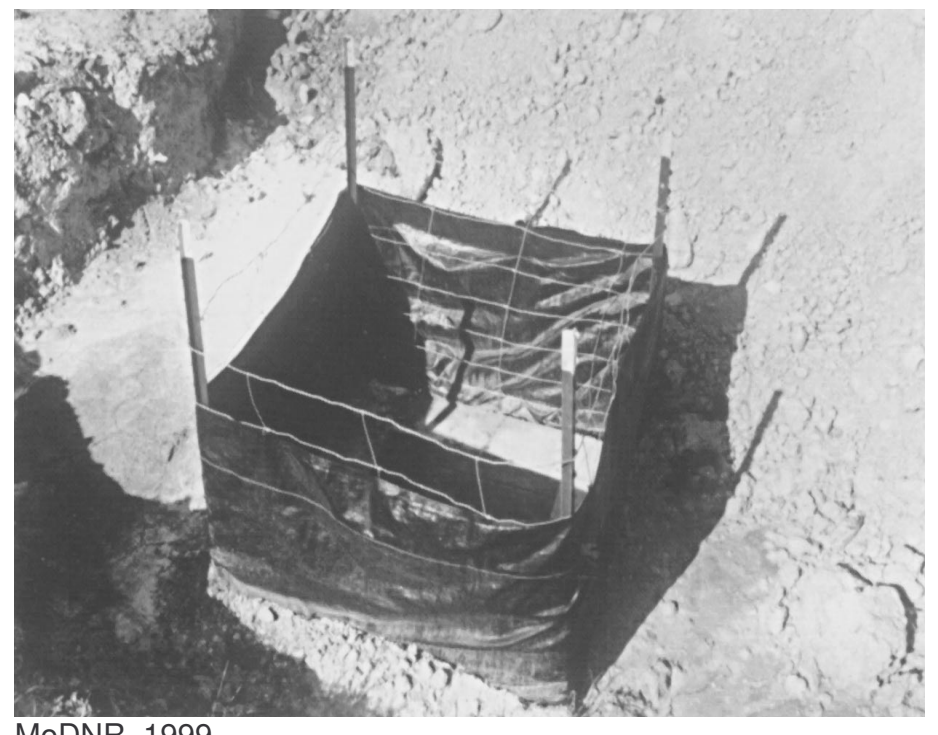

MoDNR, 1999 


\section{Inlet Protection}

\section{Drawings:}
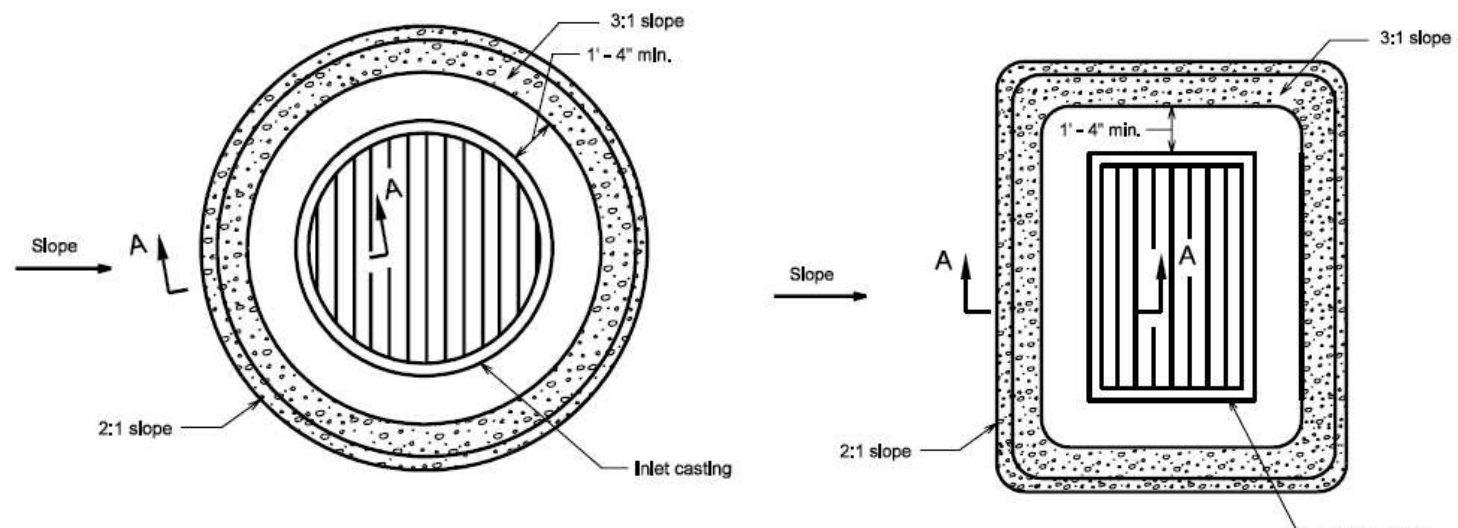

Figure 1: Aggregate Ring - Plan View

(INDOT, 2005, Standard Drawings)

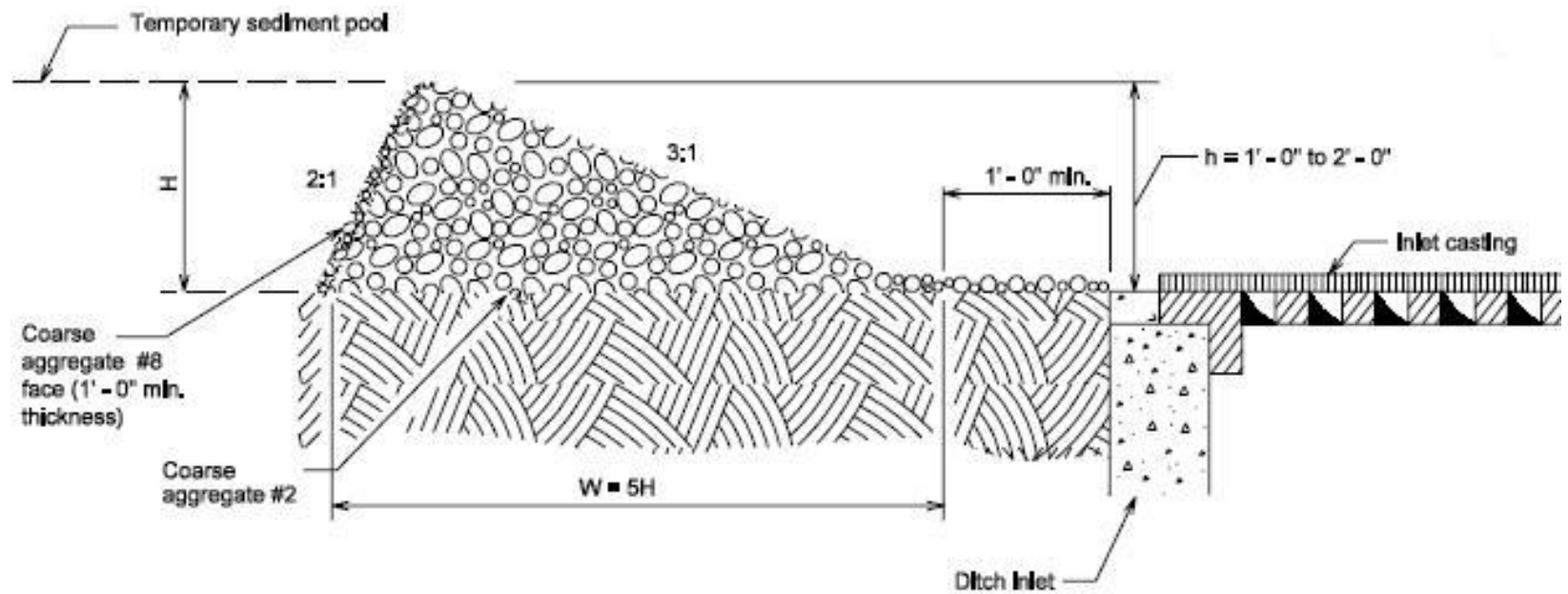

Figure 2: Aggregate Ring Cross Section (INDOT, 2005, Standard Drawings)

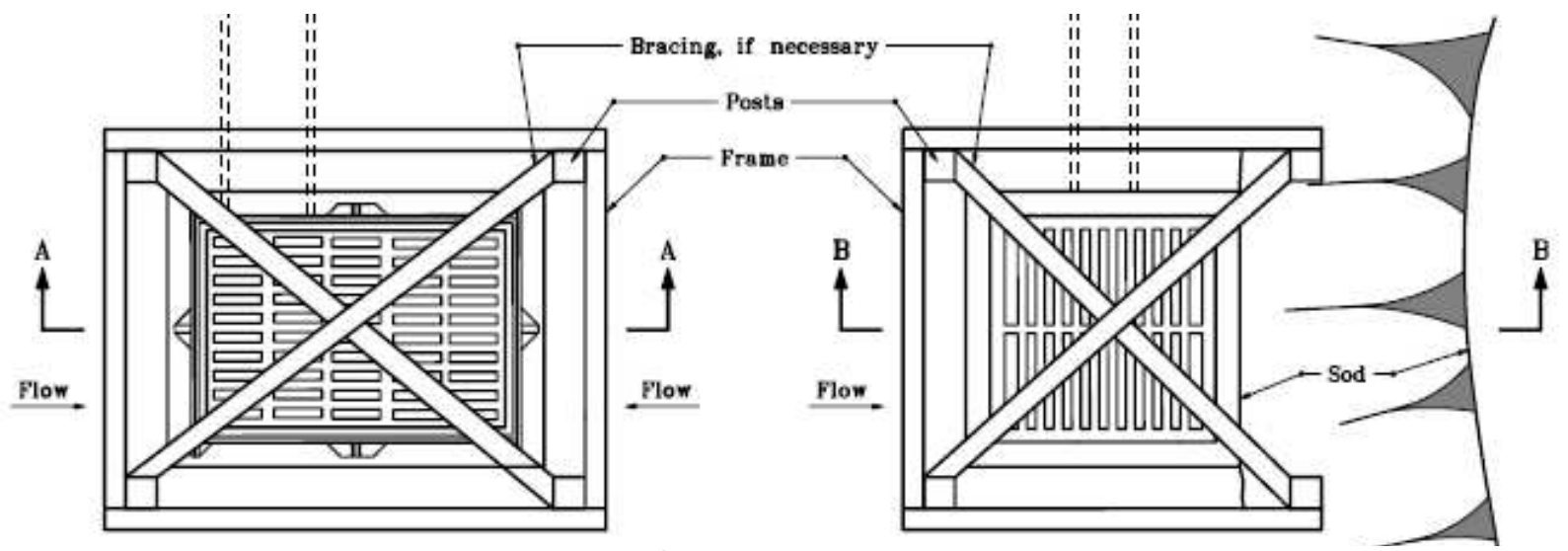

Figure 3: Geotextile Box - Plan View (INDOT, 2005, Standard Drawings) 


\section{Inlet Protection}

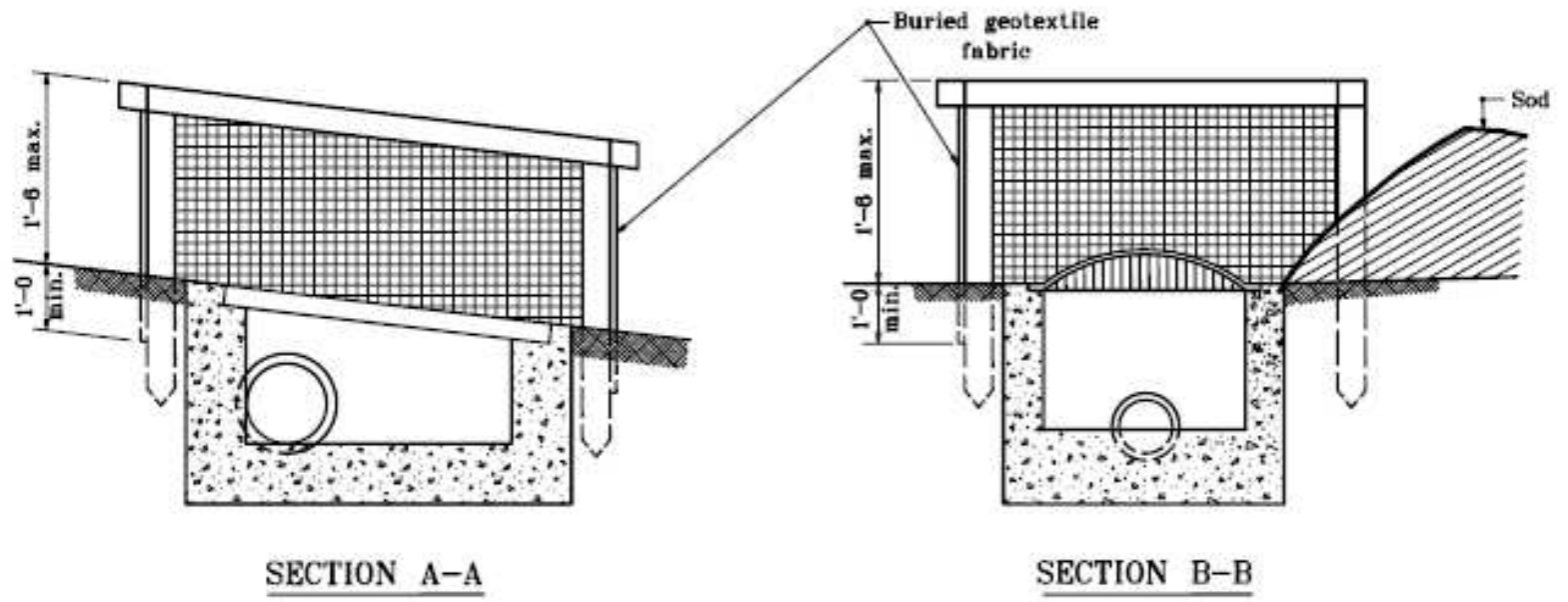

Figure 4: Geotextile Box Cross Sections

(INDOT, 2005, Standard Drawings

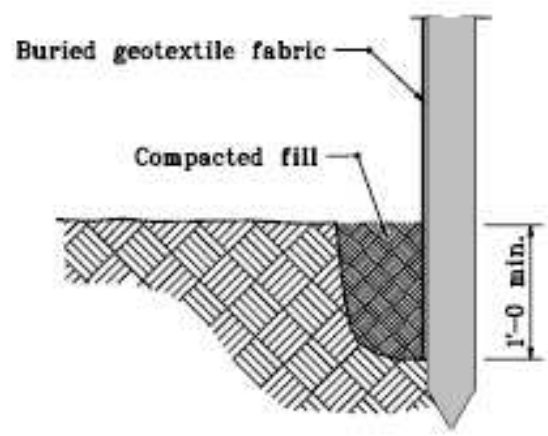

Figure 5: Geotextile Box Trench Detail

(INDOT, 2005, Standard Drawings)

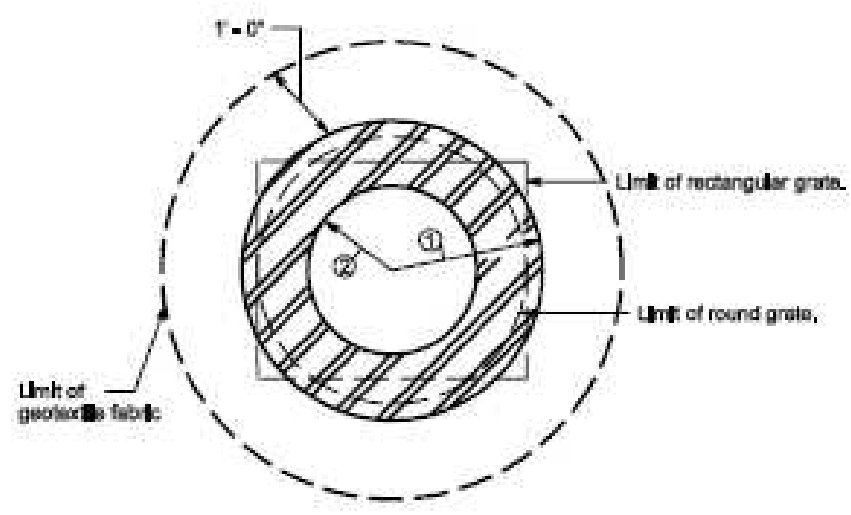

Figure 6: Slotted Barrel - Plan View (INDOT, 2005, Standard Drawings)

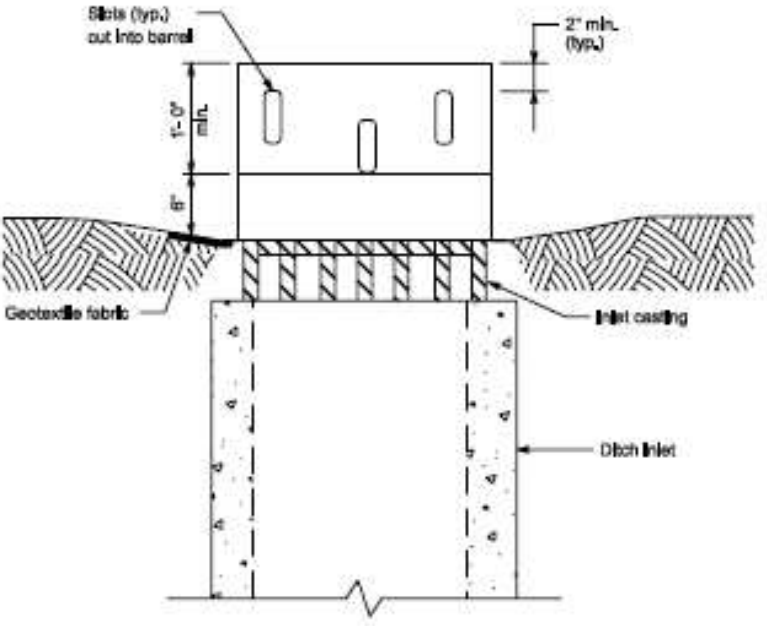

Figure 7: Slotted Barrel - Profile View (INDOT, 2005, Standard Drawings) 


\section{Inlet Protection}

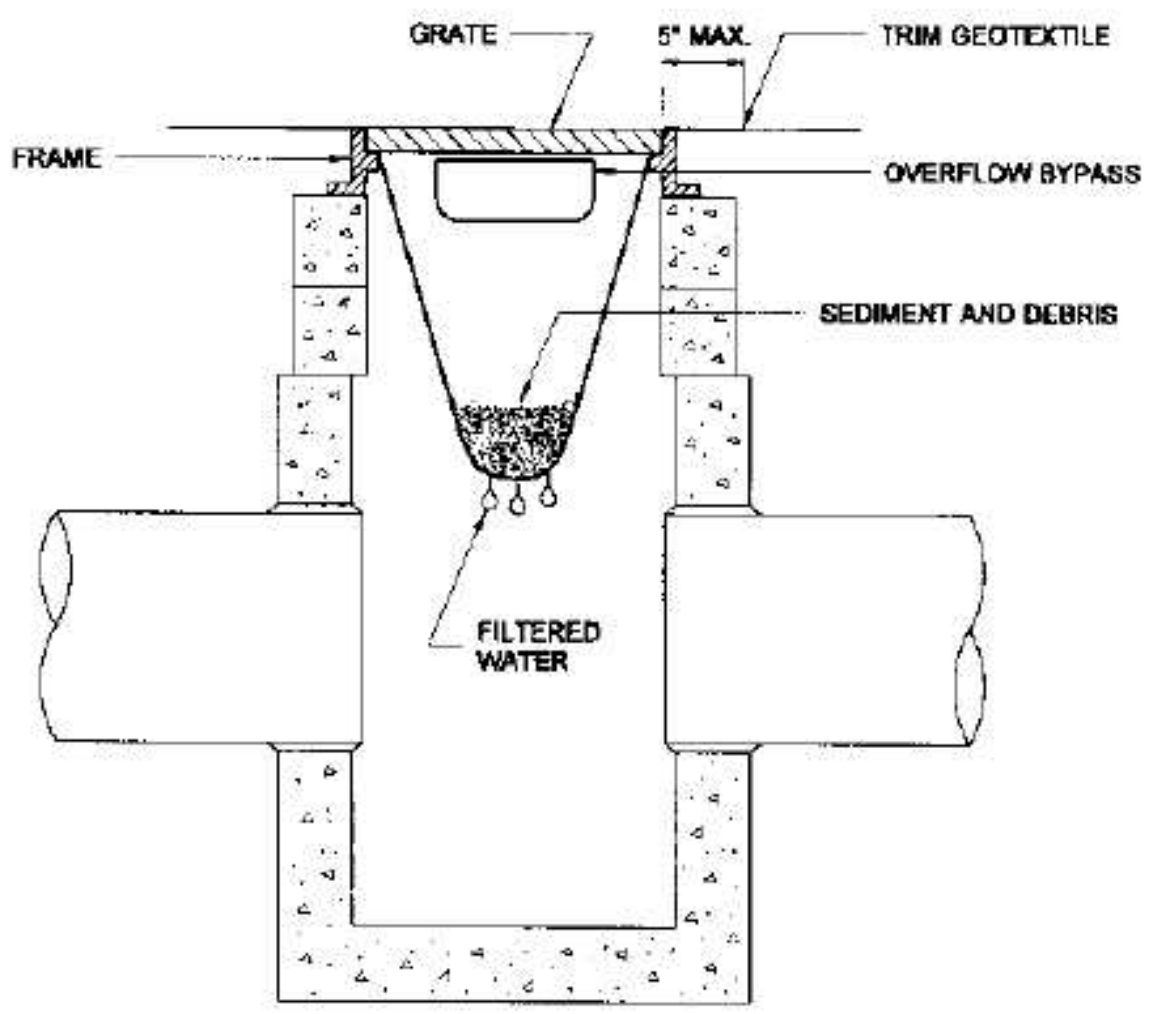

Figure 8: Typical Storm Drain Insert Configuration - Cross Section (WSDOT, 2004)

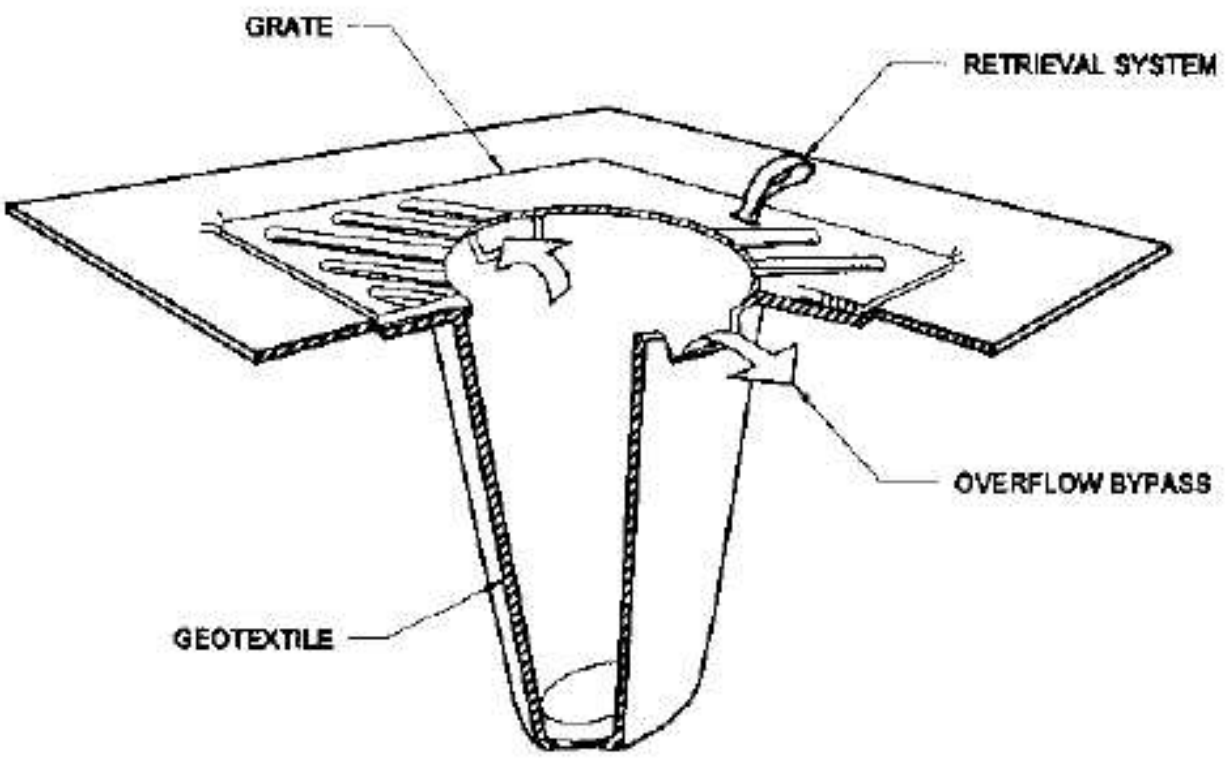

Figure 9: Typical Storm Drain Insert Configuration - Isometric View (WSDOT, 2004) 


\section{Inlet Protection}

\section{Reference:}

EPA, 2000. EPA's Storm Water Phase II Menu of Best Management Practices. Environmental Protection Agency, National Pollution Discharge Elimination System, Stormwater Team.

http://cfpub2.epa.gov/NPDES/stormwater/menuofbmps/pdf/small_files/main.pdf

INDOT, 2005. Indiana Department of Transportation Standard Drawings - Sections 100 through 300. Effective Sept. 2005. Indiana Department of Transportation, Division of Design.

http://www.in.gov/dot/div/contracts/standards/drawings/sep05/e/sep1to3.htm

INDOT, 2006. Indiana Department of Transportation Standard Specifications - Section 200. Effective Sept. 2005. Indiana Department of Transportation, Division of Design.

http://www.in.gov/dot/div/contracts/standards/book/sep06/2-2006.pdf

WSDOT, 2004. Washington State Department of Transportation Highway Runoff Manual, Publication No. M-31-16. Washington State Department of Transportation, Environmental and Engineering Service Center.

http://www.wsdot.wa.gov/fasc/EngineeringPublications/Manuals/HighwayRunoff2004.pdf

MoDNR, 1999, Protecting Water Quality, A Field Guide to Erosion, Sediment and Stormwater Best Management Practices For Developing Sites in Kansas and Missouri, Missouri Department of Natural Resources, Division of Environmental Quality.

http://www.dnr.state.mo.us/wpscd/wpcp/wpcp-guide.htm 
INDIANA DEPARTMENT OF TRANSPORTATION
Stormwater Quality Best Management Practices
Construction Sites
Sedinent Tra

\section{When to use:}

- To slow concentrated runoff velocity and catch sediment

- At the outlets of storm water diversion structures, channels, slope drains, construction site entrance wash racks

- In side ditches in lieu of, or in conjunction with, check dams

- Surrounding drop inlet protection

- Should not be used for drainage areas greater than 5 acres

\section{Advantages:}

- Versatility in location, configuration, and application

- Can be combined with many other erosion and sediment control measures

\section{Limitations:}

- Effective life span usually limited to less than 24 months

- Short available detention period does not remove fine particles such as silts and clays

\section{Description:}

Sediment traps are small impoundments that allow sediment to settle out of runoff water. They are usually installed in a drainageway or other point of discharge from a disturbed area. Temporary diversions can be used to direct runoff to the sediment trap. Sediment traps are used to detain and trap sediments in storm water runoff to protect drainage systems, receiving waters and surrounding areas. Sediment traps are formed by excavating an area or by placing an earthen embankment across a low area or drainage swale. An outlet spillway is often constructed using large aggregate to slow the release of runoff. (EPA, 2000)

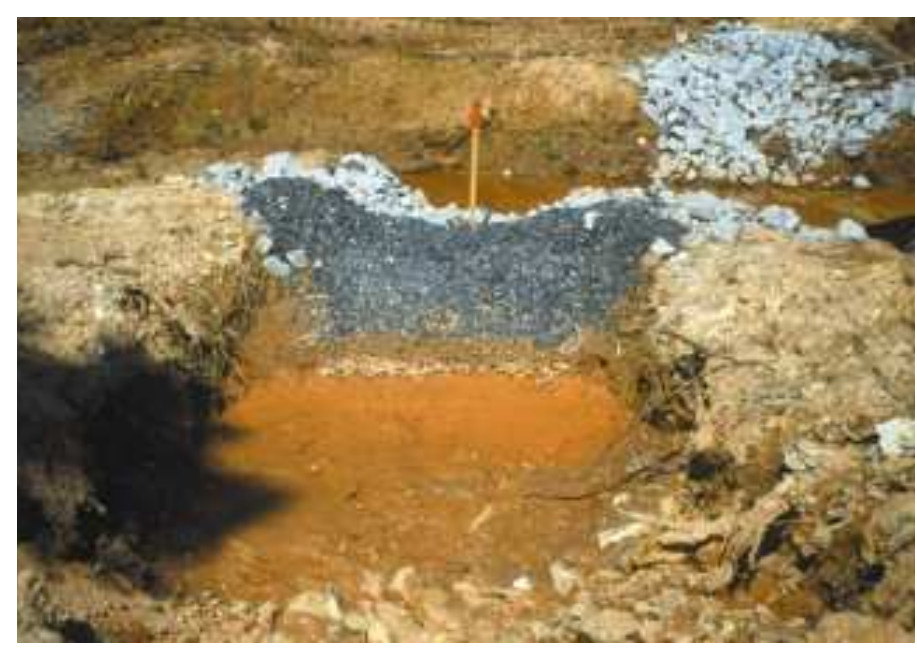

NCDOT, 2003
BMP Type:

Installation Cost:

Maintenance Effort:

Runoff Rate Control:
Sediment Control

Linear

$\$ 1,000$ -

$\$ 1,500 /$ acre of

drainage

High

Some

Some 


\section{Sediment Trap}

\section{Drawings:}

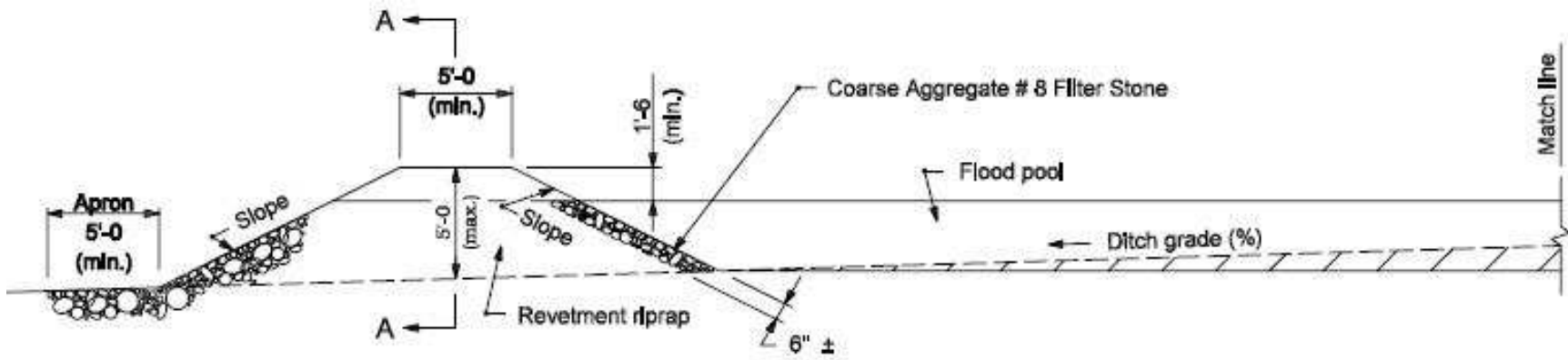

Figure 1: Sediment Trap - Ditch Application

(INDOT, 2005, Standard Drawing)

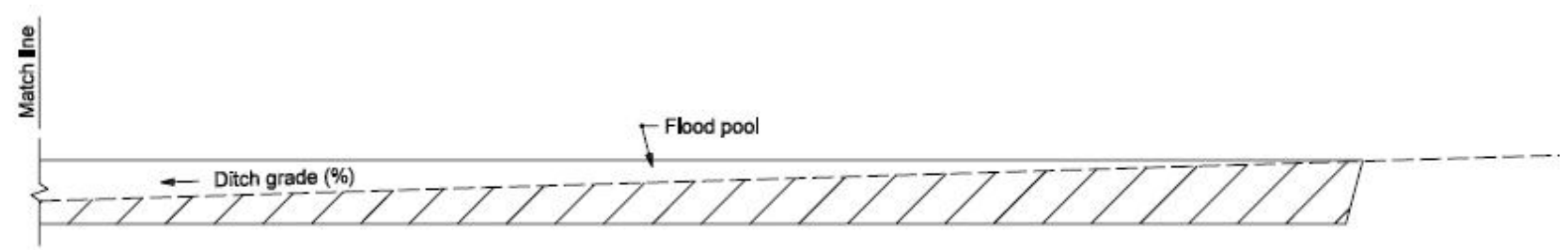

Figure 1 (cont.): Sediment Trap - Ditch Application

(INDOT, 2005, Standard Drawing)

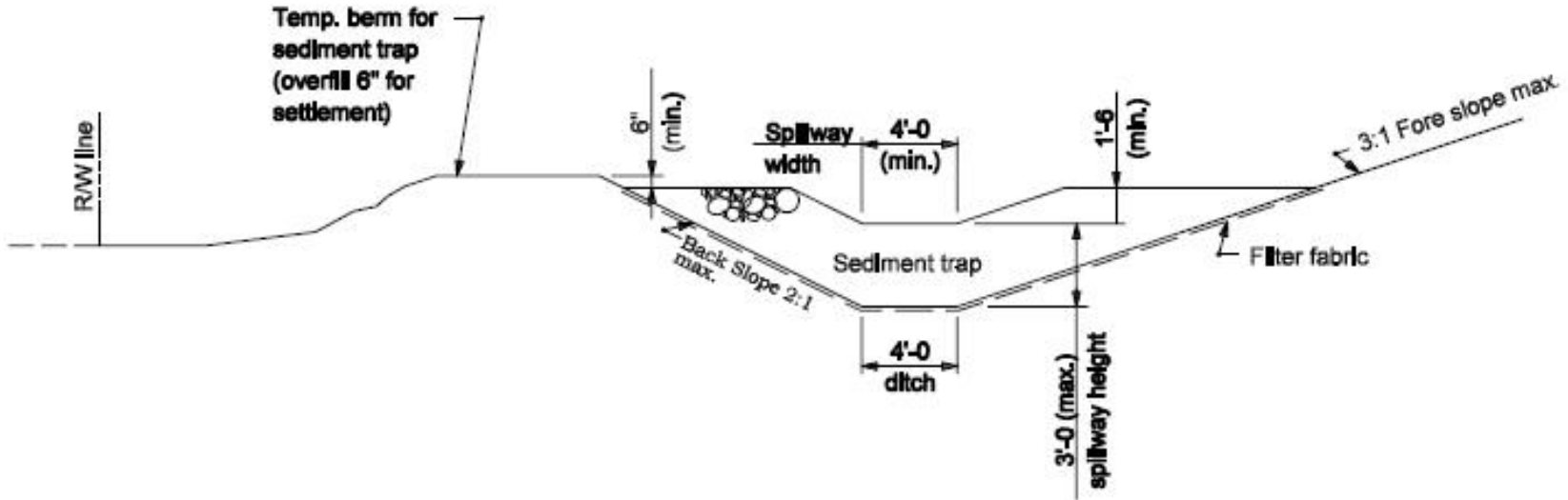

Figure 2: Sediment Trap - Cross Section

(INDOT, 2005, Standard Drawing)

\section{References:}

EPA, 2000. EPA's Storm Water Phase II Menu of Best Management Practices. Environmental Protection Agency, National Pollution Discharge Elimination System, Stormwater Team. http://cfpub2.epa.gov/NPDES/stormwater/menuofbmps/pdf/small_files/main.pdf

INDOT, 2005. Indiana Department of Transportation Standard Drawings - Sections 100 through 300. Effective Sept. 2005. Indiana Department of Transportation, Division of Design.

http://www.in.gov/dot/div/contracts/standards/drawings/sep05/e/sep1to3.htm

NCDOT, 2003. Best Management Practices for Construction and Maintenance Activities. North Carolina Department of Transportation, Division of Highways, Highway Operations. http://www.ncdot.org/doh/operations/BMP_Manual/download/BMP_Manual.pdf 
INDIANA DEPARTMENT OF TRANSPORTATION
Stormwater Quality Best Management Practices
Construction Sites
ROCK CheCK Dan

\section{When to use:}

- Concentrated flow areas such as vegetated ditches and swales

- Should NOT be used in streams

- Where temporary seeding has recently been implemented

\section{Advantages:}

- Inexpensive and easy to construct

- More stable than straw bale or fiber wattle check dams

- Rip-rap is reusable after channel is stabilized and rip-rap is removed

- Effective in medium to heavy flow situations

\section{Limitations:}

- Improper installation can facilitate erosion around ends of check dams

- Most fine silt and clay particles will pass through the voids

- Require periodic maintenance

- Temporary dams may be difficult to remove

\section{Description:}

Check dams are small dams constructed across a swale or ditch. Check dams are used to slow the velocity of concentrated flow thereby reducing erosion. As a lesser function, check dams can also be used to catch sediment from the swale itself or from the contributing drainage area as storm water runoff flows through the structure. The use of check dams should be part of the overall erosion and sediment-control process and not the sole downstream control measure. Check dams are most effective when used in combination with other storm water and

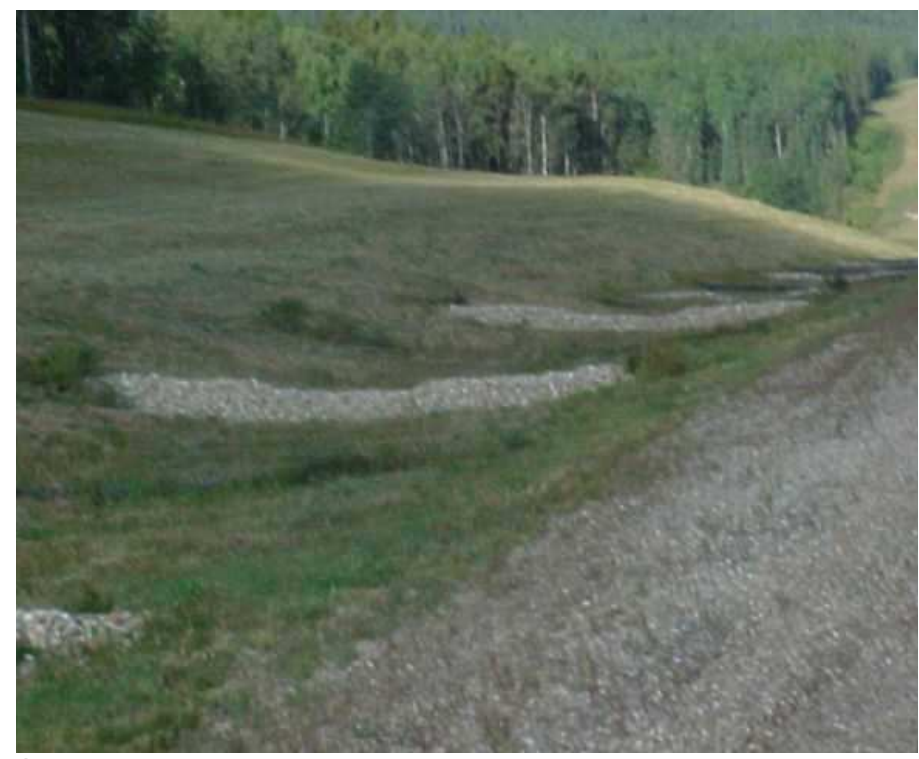

BMP Type:

Installation Cost:

Maintenance Effort:

Runoff Rate Control:

Runoff Volume Control: Some
Sediment Control Linear

$\$ 20$ - \$40/ton

High

Some erosion and sediment control measures. (Metropolitan Council, 2001) 


\section{Rock Check Dam}

\section{Drawings:}

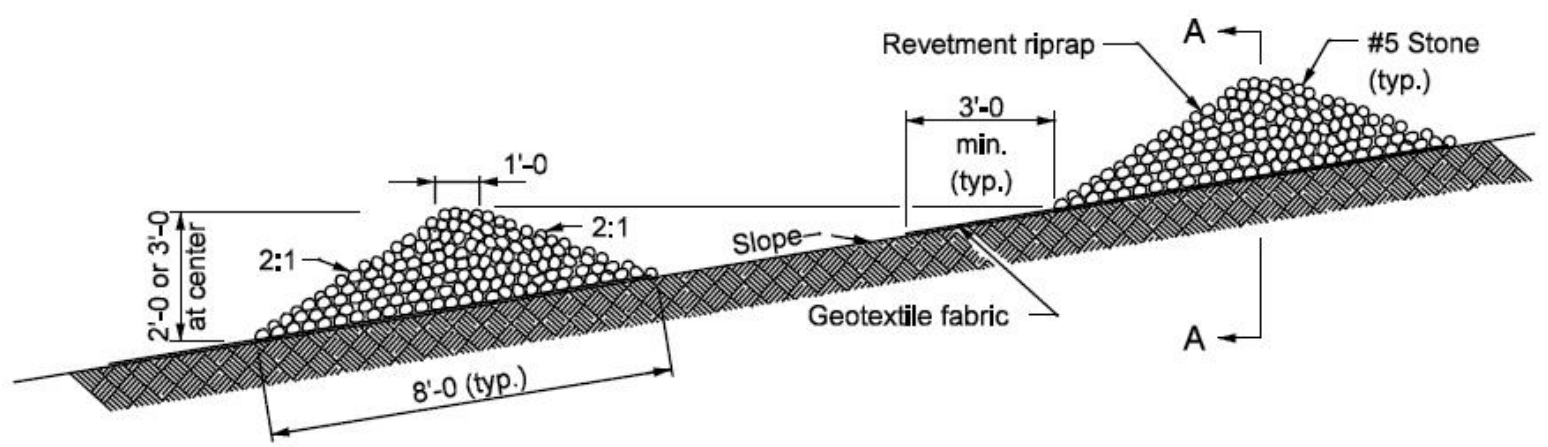

Figure 1: Profile and Spacing

(INDOT, 2005, Standard Drawings)

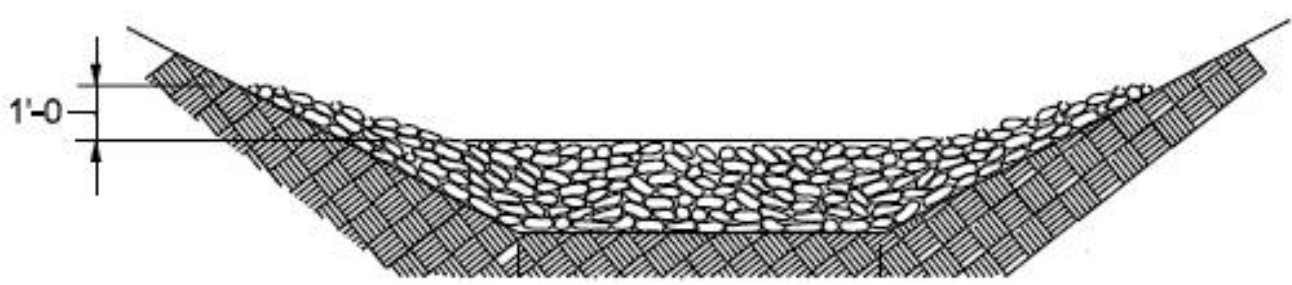

Figure 2: Cross Section

(INDOT, 2005, Standard Drawings

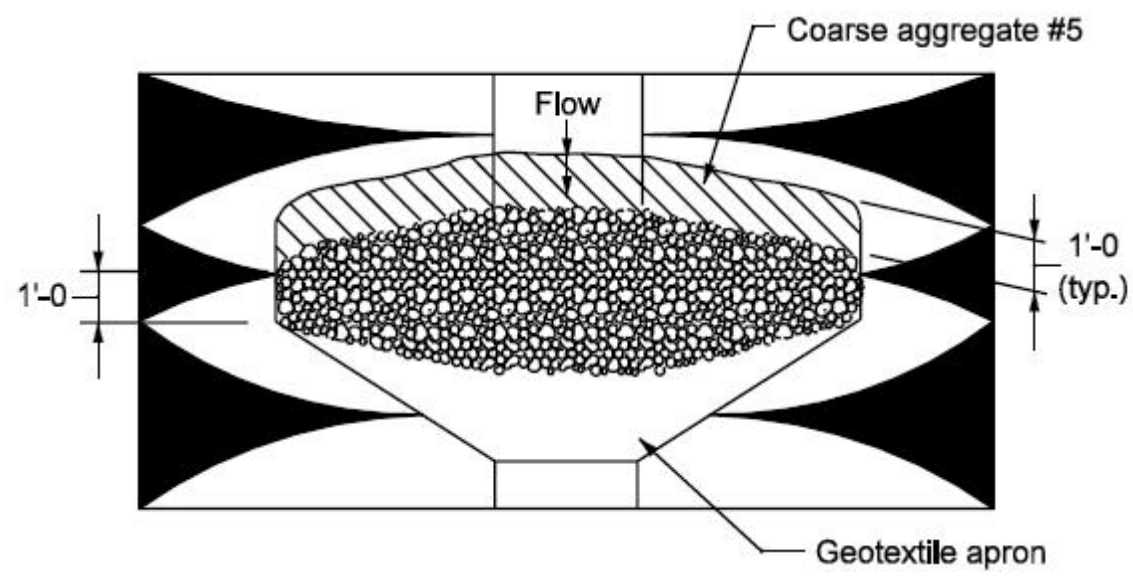

Figure 3: Plan View

References:

(INDOT, 2005, Standard Drawings)

INDOT, 2005. Indiana Department of Transportation Standard Drawings - Sections 100 through 300. Effective Sept. 2005. Indiana Department of Transportation, Division of Design.

http://www.in.gov/dot/div/contracts/standards/drawings/sep05/e/sep1to3.htm

Government of Alberta, 1998 (Revised), Erosion Control Reference Material. Alberta Transportation And Civil Engineering Division, Technical Standards Branch, Geotechnical Section.

http://www.tu.gov.ab.ca/Content/doctype372/production/erogoodbad.pdf

Metropolitan Council, 2001. Minnesota Urban Small Sites BMP Manual, Stormwater Best Management Practices for Cold Climates. Metropolitan Council Environmental Services. http://www.metrocouncil.org/environment/Watershed/BMP/manual.htm 
\begin{tabular}{l} 
INDIANA DEPARTMENT OF TRANSPORTATION \\
Stormwater Quality Best Management Practices \\
Construction Sites \\
\hline
\end{tabular}

\section{When to use:}

- For drainage areas of 5 to 100 acres.

- In conjunction with stormwater diversion measures and dewatering activities

- For new construction projects when there is adequate right-of-way

- Within interchanges, rest areas, weigh stations

- Where stormwater quality ponds are planned

\section{Advantages:}

- Good at removing larger particles

- Can treat larger volumes of water

BMP Type:

Installation Cost:

Maintenance Effort:

Runoff Rate Control:

Runoff Volume Control: Some

- Low maintenance

- Can convert to stormwater quality pond after site is stabilized

\section{Limitations:}

- Construction cost can be high

- Low ability to remove silt and clay particles

- Require more space than other measures

\section{Description:}

A temporary sedimentation basin is a controlled stormwater release structure formed by excavation, or by erecting an embankment of compacted soil or riprap, and installing an outlet structure and outlet pipe. The purpose of the basin is to detain the sediment-laden runoff from disturbed areas long enough for the majority of the sediment to settle out in the basin. This reduces sediment transport off-site. (Metropolitan Council, 2001) Generally, sediment basins are designed to be temporary. However, temporary sediment basins can be converted into permanent storm water runoff management ponds following site stabilization. (INDOT, 2005)

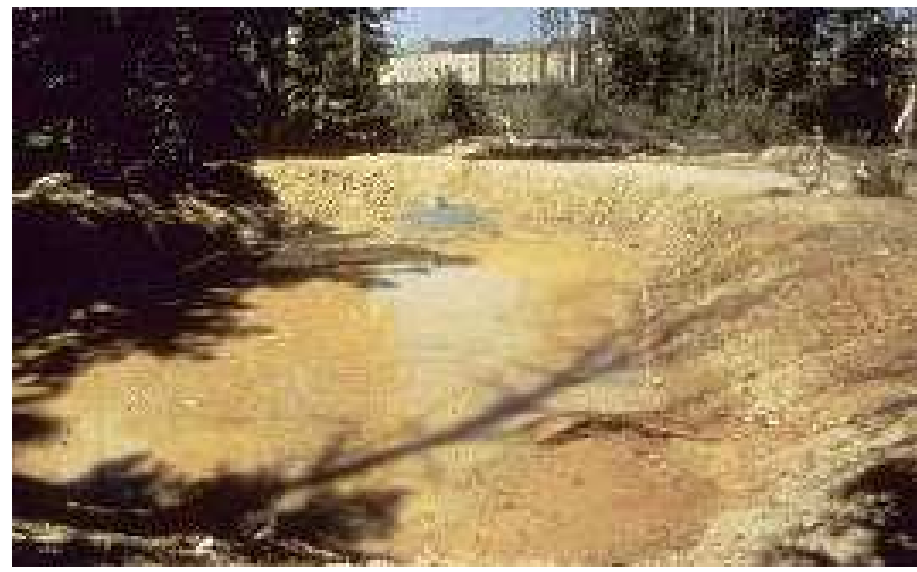

EPA, 2000 


\section{Sediment Basin}

\section{Drawings:}

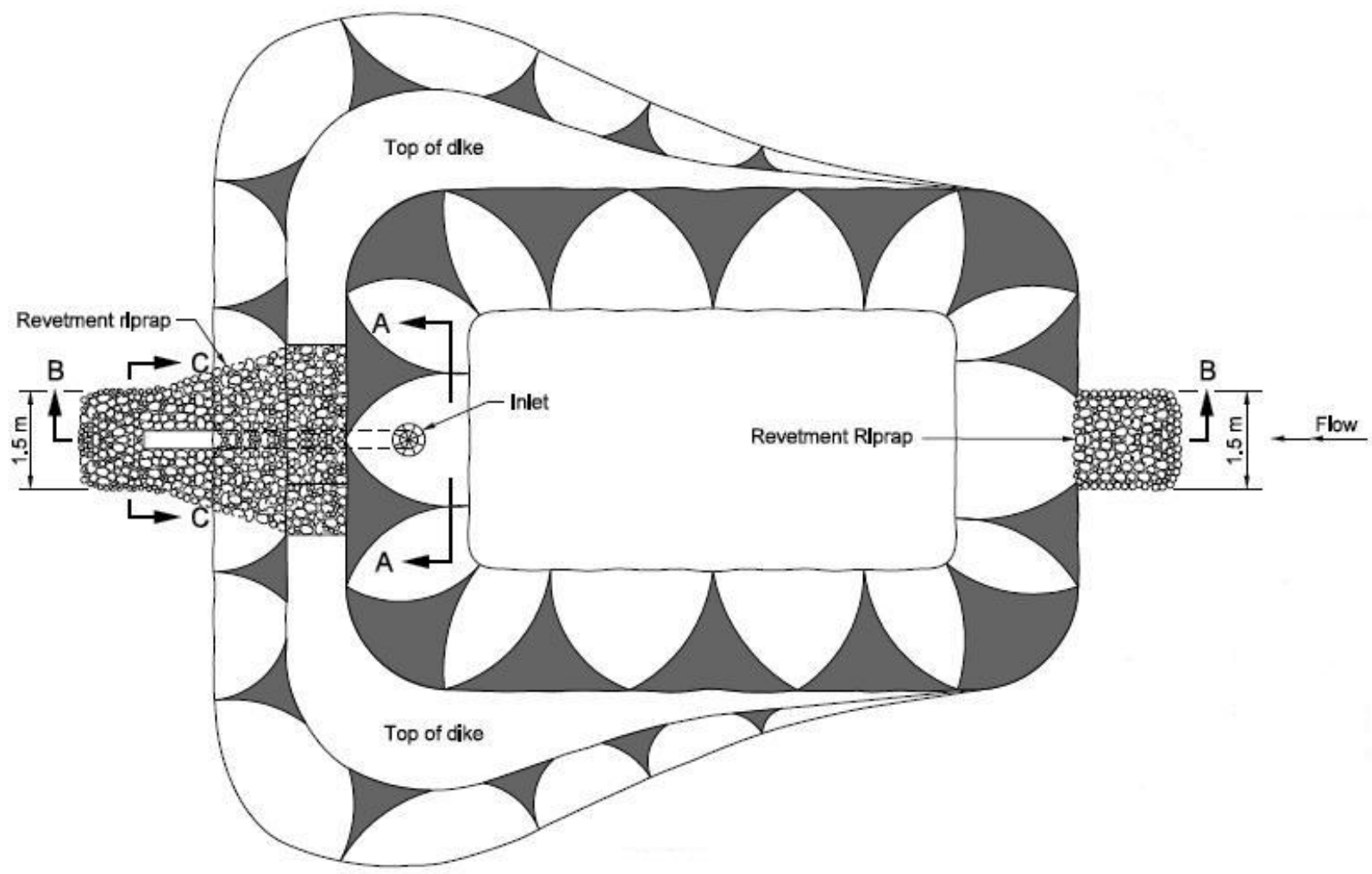

Figure 1: Sediment Basin, Plan View

(INDOT, 2005)

\section{References:}

EPA, 2000. EPA's Storm Water Phase II Menu of Best Management Practices. Environmental Protection Agency, National Pollution Discharge Elimination System, Stormwater Team. http://cfpub2.epa.gov/NPDES/stormwater/menuofbmps/pdf/small_files/main.pdf

INDOT, 2005. Indiana Department of Transportation Design Manual, Part 4, Chapter 37 - Temporary Erosion and Sediment Control. Indiana Department of Transportation, Division of Design. http://www.in.gov/dot/div/contracts/standards/dm/Part04Vol.2/Ch37/ch37.htm

Metropolitan Council, 2001. Minnesota Urban Small Sites BMP Manual, Stormwater Best Management Practices for Cold Climates. Metropolitan Council Environmental Services. http://www.metrocouncil.org/environment/Watershed/BMP/manual.htm 
APPENDIX 4

POST-CONSTRUCTION BMP FACT SHEETS 


\section{INDIANA DEPARTMENT OF TRANSPORTATION}

\section{Stormwater Quality Best Management Practices}

Post-Construction Stormwater Treatment

\section{Dry Pond}

\section{When to use:}

- In hydrologic soil types A and B or in C and D soil with sloped bottom or underdrains

- In low lying areas

- Water table is at least 3 feet below the pond bottom

- Drainage area of at least 2 acres

- Hydraulic head of 3 to 8 feet

- Not practical for use in ultra urban settings

- Cannot be placed on steep or unstable slopes

\section{Advantages:}

- Can achieve $80 \%$ TSS removal as a stand alone BMP

- Variable ability to accept pollutants from offsite hotspots

- Low construction cost

- Low to moderate maintenance costs

- Moderate community acceptance

- Provides water quantity benefit in the form of runoff rate control

- Long effective life

- Can act as sediment trap/basin during construction phase

- Excellent retrofit opportunity for existing dry ponds

- Typically requires less excavation than wet ponds

\section{Limitations:}

- Requires additional right-of-way beyond standard clear zone limits

- Removal rates vary widely depending on site conditions and storm events

- Low wildlife habitat benefit

- Minimum set-back from high water level required (see local codes)

- Heavy storms may resuspend sediments

\section{BMP Type:}

TSS Removal:

Nitrogen Removal:

Phosphorous Removal:

Metal Removal:

E. coli Removal:

Runoff Volume Control:

Runoff Rate Control:

Annual Maintenance

Cost:

Relative Construction

Cost:

Effective Life:

Reported as a percentage of Construction Cost

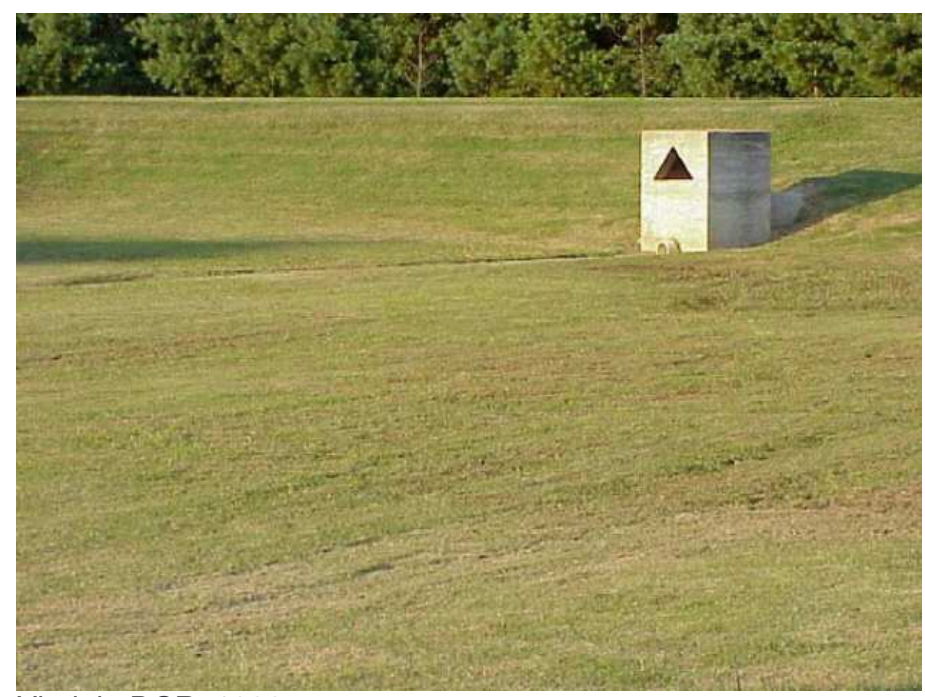

Virginia DCR, 1999 


\section{Dry Pond}

\section{Description:}

Dry ponds, also called "detention ponds," are stormwater basins that are designed to intercept a volume of stormwater runoff and temporarily impound the water for gradual release to the receiving stream or storm sewer system. Traditional dry pond designs do not provide much water quality benefit. However, with a few modifications, dry ponds can be very effective at removing pollutants. Extended detention dry ponds can be designed as two-stage facilities. In these cases, the upper stage stores and reduces flood peaks and the lower stage is designed for water quality control. The lower stage volume may be able to treat a certain depth of water over the impervious area, such as 0.5 inch or a design storm frequency, such as the 1-year 24-hour storm event. Following storm events, dewatering times typically range between 24 and 48 hours. This residence time may allow for greater than 90 percent removal of particulates through settling. A shallow marsh or wetland may be incorporated into the design to facilitate removal of nitrogen and phosphorus. The incorporation of a forebay, energy dissipator, or pretreatment facility before flow enters the pond from a channel or pipe is important to lessen the impact of sediment and grit on the pond and to facilitate pond maintenance. When dry ponds are installed in C or D type soils, the bottom of the basin should be sloped to allow for complete dewatering and avoid ponded areas. Perforated tile underdrains may also be installed for dewatering.

\section{Drawings:}

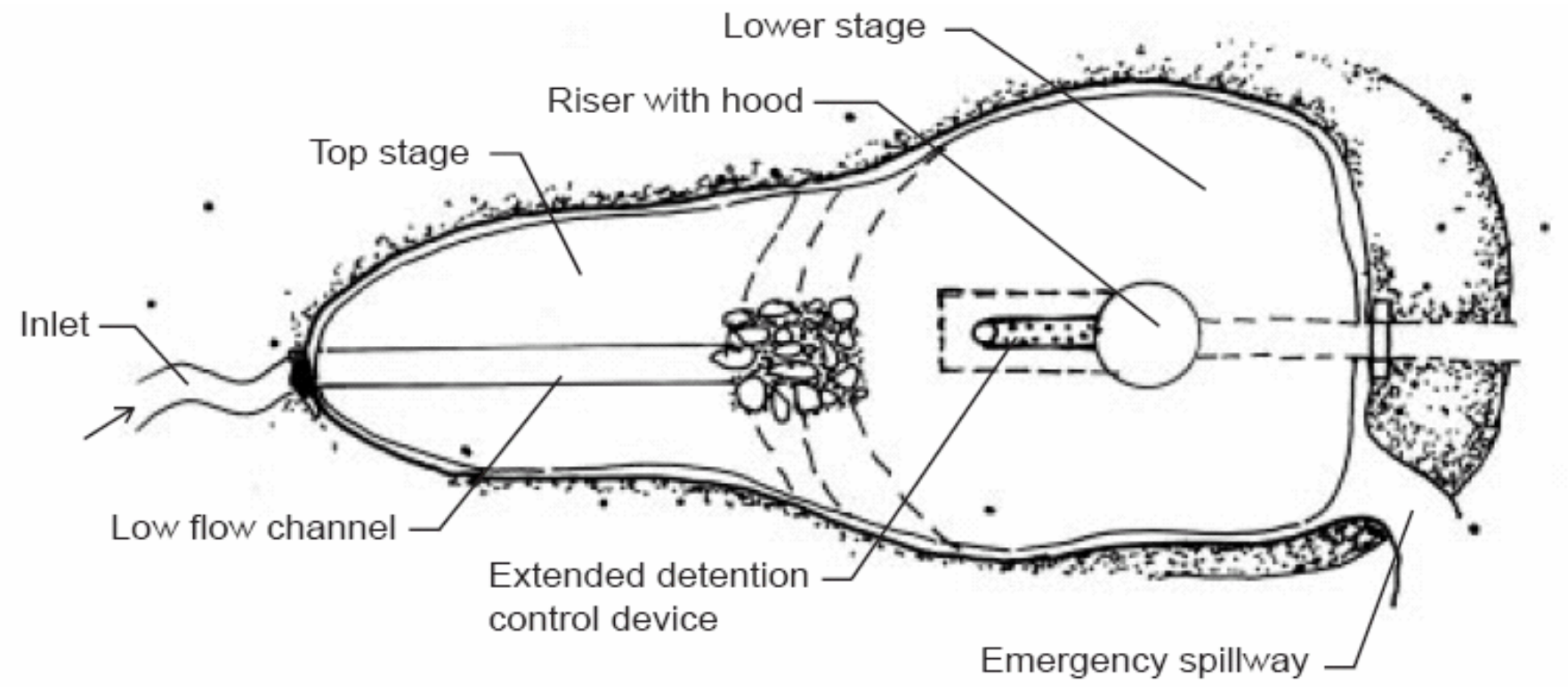

Figure 1: Dry Extended Detention Pond - Plan View (NRCS, 2003) 


\section{Dry Pond}

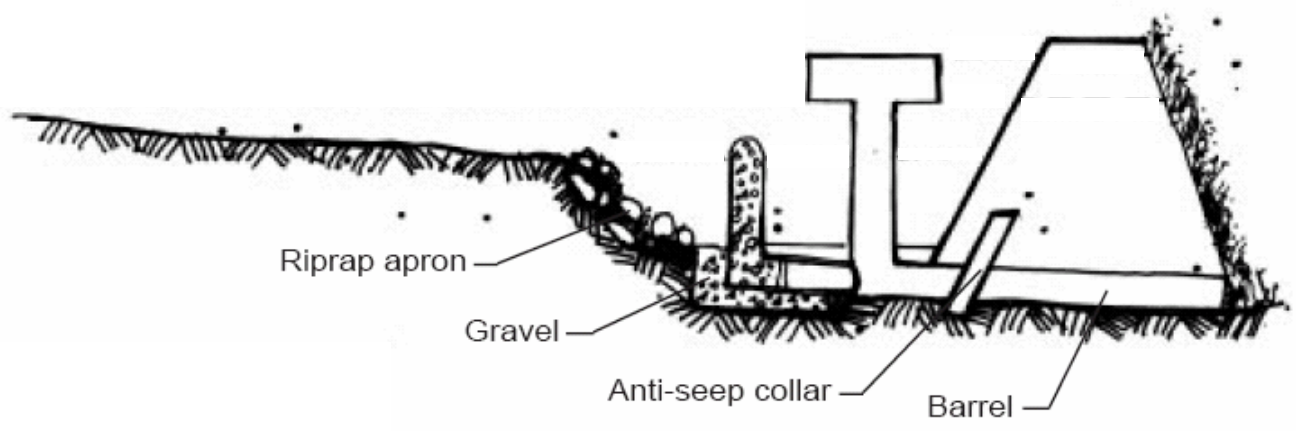

Figure 2: Dry Extended Detention Pond - Section View (NRCS, 2003)

\section{Reference:}

NRCS, 2003. Urban BMPs - Water Runoff Management. NRCS Watershed Science Institute with Mississippi State University Center for Sustainable Design.

http://www.wsi.nrcs.usda.gov/products/UrbanBMPs/water.html

Virginia DCR, 1999. Virginia Stormwater Management Handbook. Commonwealth of Virginia, Department of Conservation and Recreation.

http://www.dcr.state.va.us/sw/stormwat.htm\#handbook 


\section{INDIANA DEPARTMENT OF TRANSPORTATION}

Stormwater Quality Best Management Practices

Post-Construction Stormwater Treatment

\section{Extended Detention Pond With Micropool}

\section{When to use:}

- In hydrologic soil types C and D or with a clay liner

- In low lying areas

- Water table is at least 3 feet below the pond bottom

- Drainage area of at least 2 acres

- Hydraulic head of 3 to 6 feet

- Not practical for use in ultra urban settings

- Cannot be placed on steep or unstable slopes

\section{Advantages:}

- Can achieve $80 \%$ TSS removal as a stand alone BMP

- Variable ability to accept pollutants from hotspots

- Low construction cost

- Low to moderate maintenance cost

- Moderate community acceptance

- Medium wildlife habitat benefit

- Provides water quantity benefit in the form of runoff rate control

- Long effective life

- Can act as sediment trap/basin during construction phase

- Excellent retrofit opportunities for existing dry or wet ponds

\section{Limitations:}

- Requires additional right-of-way beyond standard clear zone limits

- Removal rates vary widely depending on site conditions and storm events

- Minimum set-back from high water level required (see local codes)

- Heavy storms may resuspend sediments

- Potential for mosquito breeding areas
- Adequate source of water needed to maintain permanent water pool areas year round

- Water can become stagnant

- Evaporation can concentrate levels of salt and algae

- Embankment may be regulated as a dam by IDNR

\begin{tabular}{||ll||}
\hline \hline & Retention/Detention \\
BMP Type: & - Non-Linear \\
TSS Removal: & $46-98 \%$ \\
Nitrogen Removal: & $28-50 \%$ \\
Phosphorous Removal: & $20-94 \%$ \\
Metal Removal: & N/A \\
E. coli Removal: & N/A \\
Runoff Volume Control: & Varies \\
Runoff Rate Control: & High \\
Annual Maintenance & $5-7 \%{ }^{1}$ \\
Cost: & \\
Relative Construction & Low \\
Cost: & $20-50$ years \\
Effective Life: & \\
\hline
\end{tabular}

${ }^{7}$ Reported as a percentage of Construction Cost

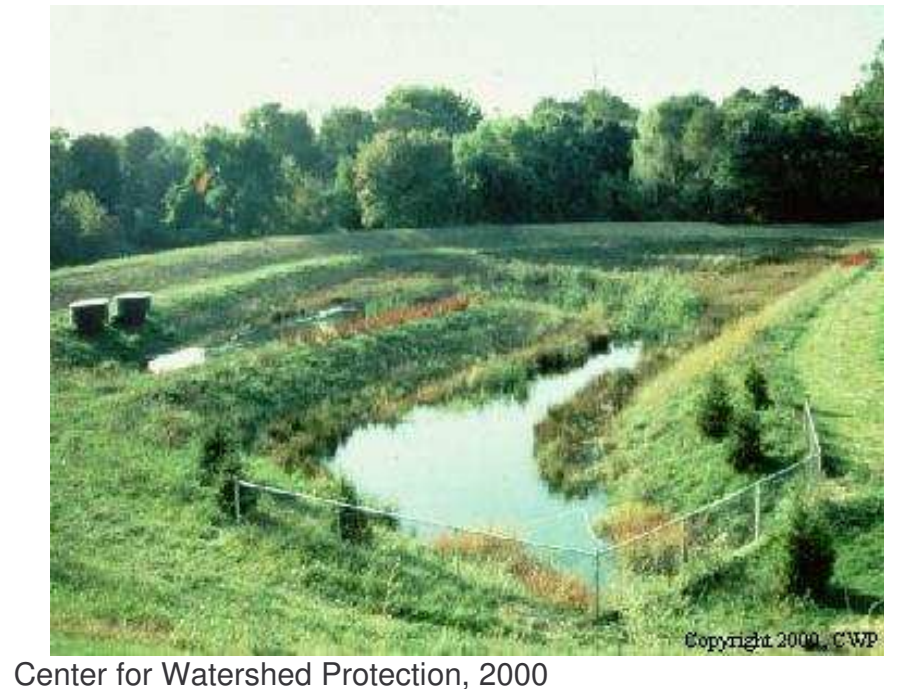




\section{Extended Detention Pond With Micropool}

\section{Description:}

Typical extended detention pond configurations include shallow wetlands or small ponding areas in combination with dry areas, along with the incorporation of a micropool at the outlet (Figure 1). Extended detention ponds with micropools incorporate a permanent pool component that is absent in dry ponds. However, they differ from wet ponds in the amount of the overall basin dedicated to the permanent pool. Runoff is treated by settling and algal uptake in the forebay and micropool. Pollutant removal occurs through settling, biological activity, and adsorption in the areas lateral to the permanent pool. If a shallow wetland is incorporated into the design, microbial breakdown of pollutants can be added to the list of pollutant removal mechanisms.

\section{Drawings:}

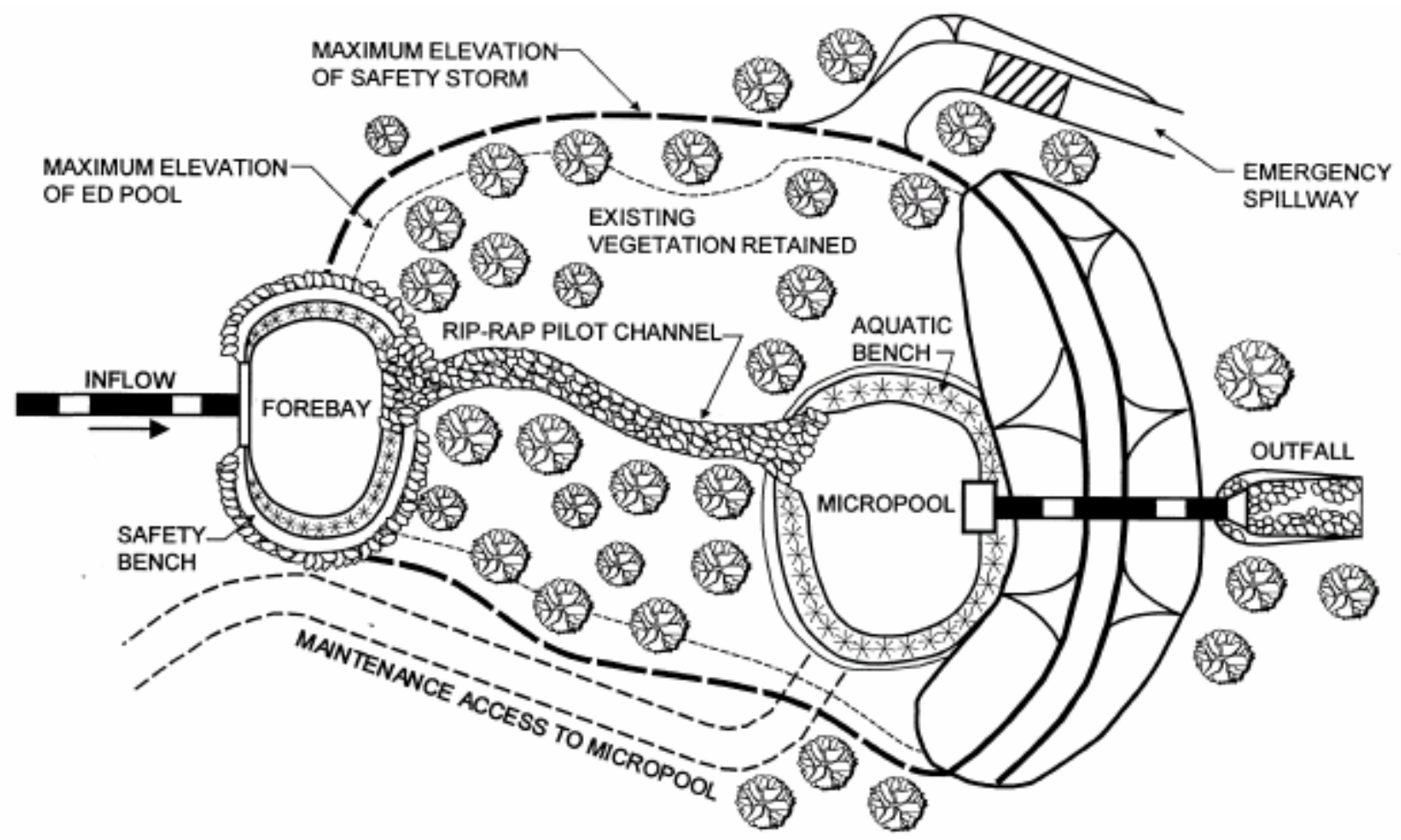

Figure 1: Typical Extended Wet Detention - Plan View (with shallow wetland and micropool options) (Georgia Stormwater Management Manual, 2001) 


\section{Extended Detention Pond With Micropool}

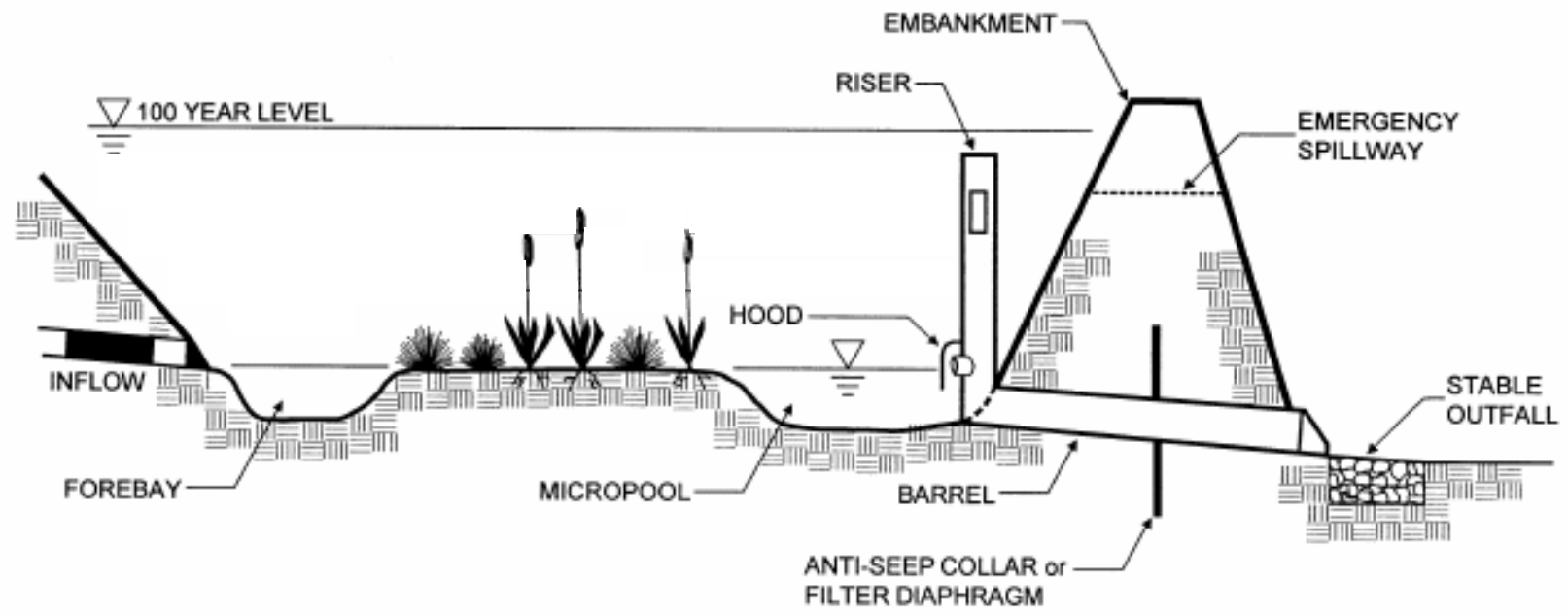

Figure 2: Typical Extended Wet Detention - Section View (with shallow wetland and micropool options)

(Modified from Georgia Stormwater Management Manual, 2001)

\section{References:}

Georgia Stormwater Management Manual, 2001. Volume 2, Section 3.2.1.

http://www.georgiastormwater.com/

Center for Watershed Protection, Stormwater Manager's Resources Center, 2000

http://www.stormwatercenter.net/ 


\section{INDIANA DEPARTMENT OF TRANSPORTATION}

Stormwater Quality Best Management Practices

Post-Construction Stormwater Treatment

\section{Wet Pond}

\section{When to use:}

- In hydrologic soil types C and D or with clay liner

- In low lying areas

- Water table is at least 3 feet below the pond bottom

- Drainage area of at least 2 acres

- Hydraulic head of 3 to 6 feet

- Not practical for use in ultra urban settings

- Cannot be placed on steep or unstable slopes

\section{Advantages:}

- Can achieve $80 \%$ TSS removal as a stand alone BMP

- Variable ability to accept pollutants from hotspots

- Low construction cost

- Low to moderate maintenance cost

- Moderate community acceptance

- Medium wildlife habitat benefit

- Provides water quantity benefit in the form of runoff rate control

- Long effective life

- Can act as sediment trap/basin during construction phase

- Retrofit opportunities for existing wet ponds

- Large sediment storage volume below water

\section{Limitations:}

- Requires additional right-of-way beyond standard clear zone limits

- Removal rates vary widely depending on site conditions and storm events

- Minimum set-back from high water level required (see local codes)

- Heavy storms may resuspend sediments

- Potential for mosquito breeding areas

- Adequate source of water needed to maintain permanent water pool areas year round

- Water can become stagnant

- Evaporation can concentrate levels of salt and algae

- Embankment may be regulated as a dam by IDNR

\begin{tabular}{|c|c|}
\hline & Retention/ \\
\hline BMP Type: & $\begin{array}{l}\text { Detention - Non- } \\
\text { Linear }\end{array}$ \\
\hline TSS Removal: & $46-98 \%$ \\
\hline Nitrogen Removal: & $28-50 \%$ \\
\hline Phosphorous Removal: & $20-94 \%$ \\
\hline Metal Removal: & $24-89 \%$ \\
\hline E. coli Removal: & $\mathrm{N} / \mathrm{A}$ \\
\hline Runoff Volume Control: & Low \\
\hline Runoff Rate Control: & High \\
\hline $\begin{array}{l}\text { Annual Maintenance } \\
\text { Cost: }\end{array}$ & $3-5 \%{ }^{1}$ \\
\hline $\begin{array}{l}\text { Relative Construction } \\
\text { Cost: }\end{array}$ & Low \\
\hline Effective Life: & $20-50$ years \\
\hline
\end{tabular}

Reported as a percentage of Construction Cost

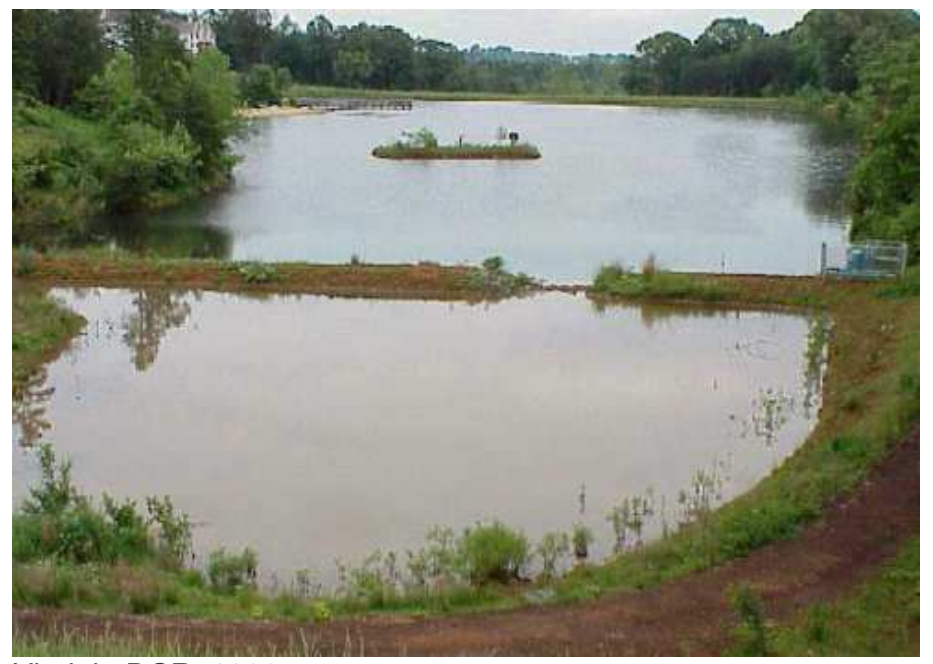

Virginia DCR, 1999 


\section{Wet Pond}

\section{Description:}

The wet pond is a facility which removes sediment, organic nutrients, and trace metals from stormwater runoff. This is accomplished by slowing down stormwater using an in-line permanent pool or pond effecting settling of pollutants. The wet pond is similar to a dry pond, except that a permanent volume of water is incorporated into the design. Biological processes occurring in the permanent pond pool aid in reducing the amount of soluble nutrients present in the water, such as nitrate and ortho-phosphorus.

The permanent pool is usually maintained at a depth between 6 and $8 \mathrm{ft}$. High pollutant removal efficiencies for sediment, phosphorus, and nitrogen are achievable when the volume of the permanent pool is at least three times the water quality volume (the volume to be treated). The shape of the pool can help improve the performance of the pond. Maximizing the distance between the inlet and outlet provides more time for mixing of the new runoff with the pond water and settling of pollutants.

Soil conditions are important for the proper functioning of the wet pond. The pond is a permanent pool, and thus must be constructed such that the water must not be allowed to exfiltrate from the permanent portion of the pool. It is difficult to form a pool in soils with high infiltration rates soon after construction. Eventually, however, deposition of silt at the bottom of the pond will help slow infiltration. If extremely permeable soils exist at the site (hydrologic soil group A or B), a geosynthetic or clay liner may be necessary.

\section{Drawings:}

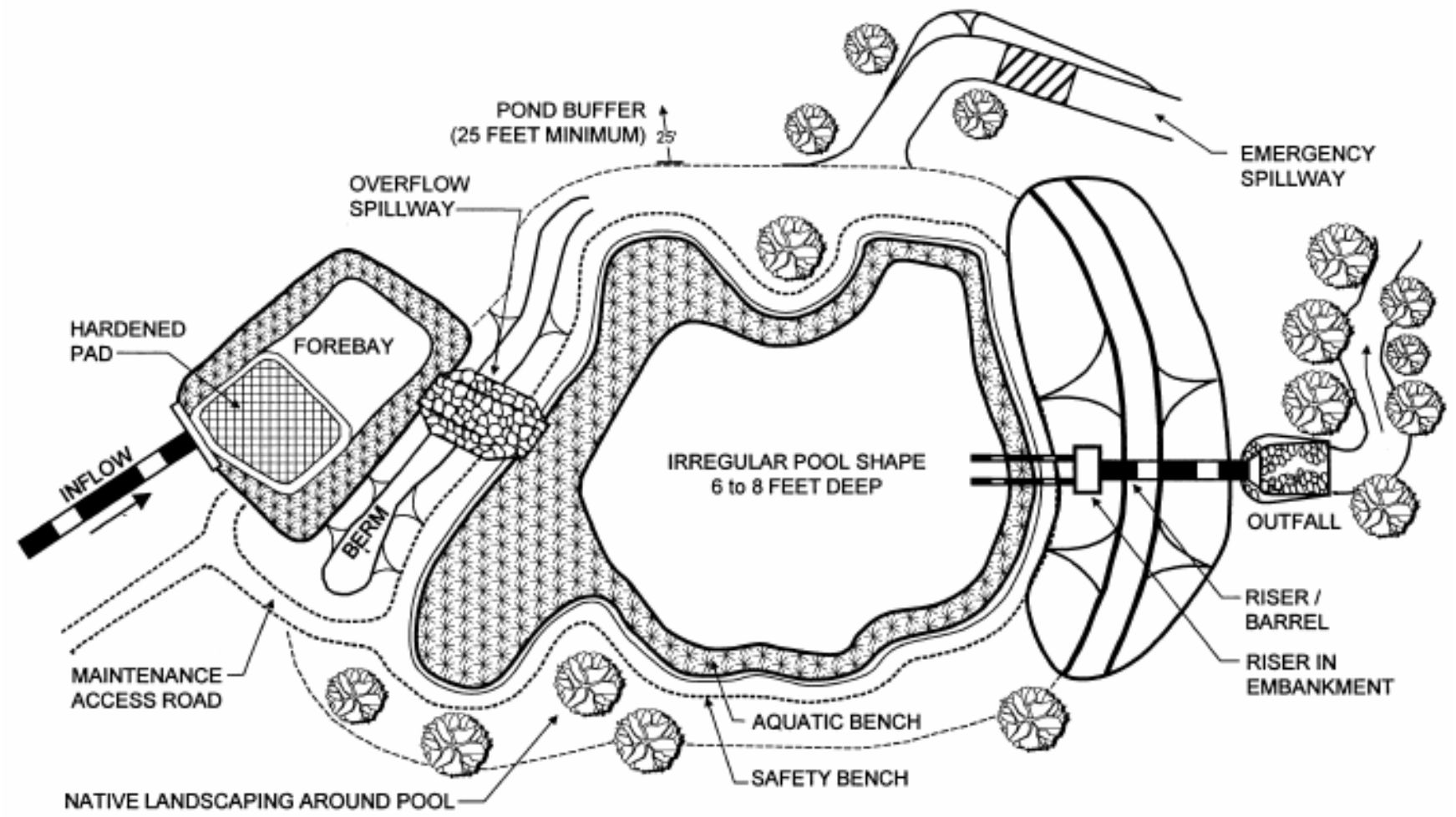

Figure 1: Typical Wet Pond with Wetland Perimeter - Plan View (Georgia Stormwater Management Manual, 2001) 


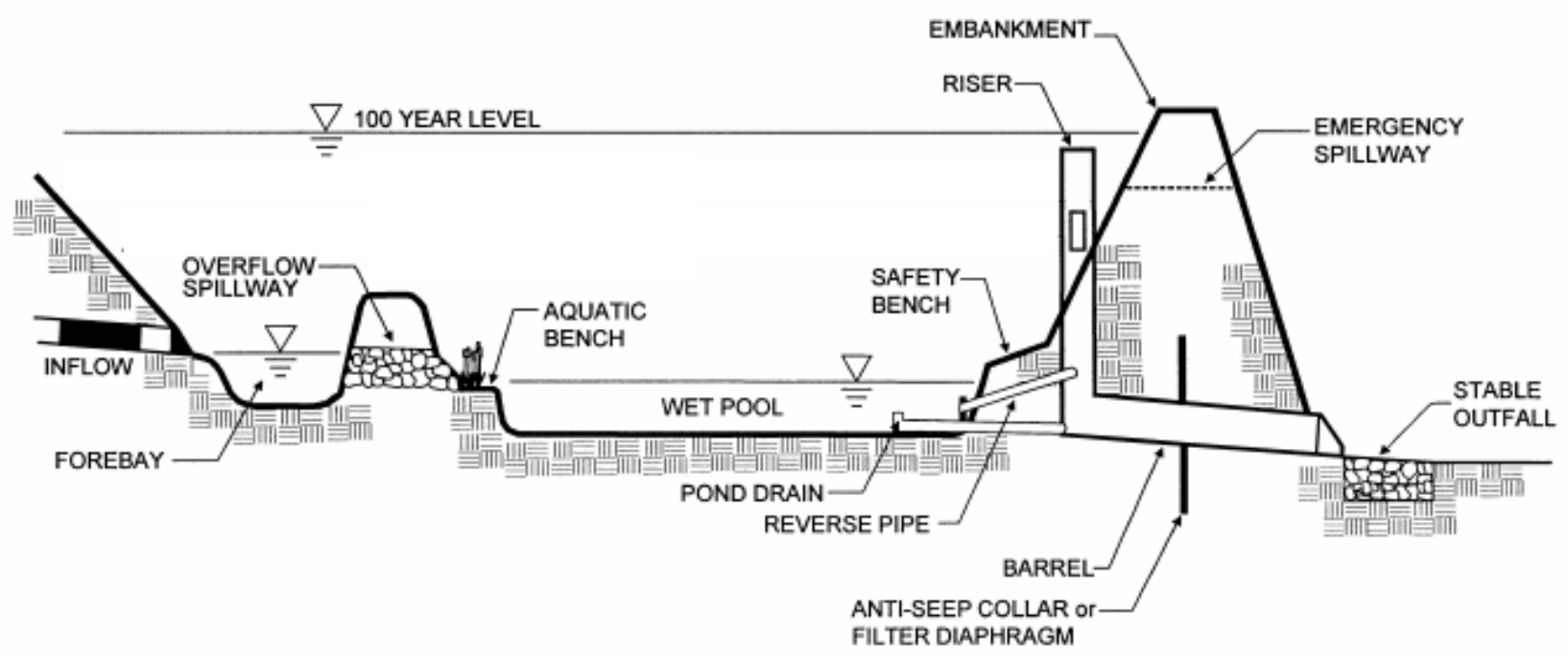

Figure 1: Typical Wet Pond - Section View

(Modified from Georgia Stormwater Management Manual, 2001)

\section{References:}

Georgia Stormwater Management Manual, 2001. Volume 2, Section 3.2.1.

http://www.georgiastormwater.com/

Virginia DCR, 1999. Virginia Stormwater Management Handbook. Commonwealth of Virginia, Department of Conservation and Recreation.

http://www.dcr.state.va.us/sw/stormwat.htm\#handbook

PADEP, 2005. Draft Pennsylvania Stormwater Management Manual, Section 6. Pennsylvania Department of Environmental Protection.

http://www.dep.state.pa.us/dep/subject/advcoun/stormwater/Manual DraftJan05/Section06-StructuralBMPs-part1.pdf 
INDIANA DEPARTMENT OF TRANSPORTATION
Stormwater Quality Best Management Practices
Post-Construction Stormwater Treatment
Dry SWR e

\section{When to use:}

- Any soil type

- Water table is at least 3 feet below the swale invert

- Drainage area of 2 to 4 acres

- Hydraulic head of 2 to 6 feet

- Not practical for use in ultra urban settings

- Cannot be placed on steep or unstable slopes

\section{Advantages:}

- Can achieve $80 \%$ TSS removal as a stand alone BMP

- Can accept pollutants from offsite hotspots

- Low construction cost

- Low maintenance cost

- Moderate community acceptance

- Relatively easy to design, install and maintain

\section{Limitations:}

- Removal rates vary widely depending on site conditions and storm events

- Minimum set-back from high water level required (see local codes)

- Heavy storms may resuspend sediments

- Potential for mosquito breeding areas

- Limited runoff quantity and rate control for small storm events

- Effective life may be reduced if not properly maintained

- Low wildlife habitat benefit

- Irrigation may be necessary to maintain vegetative cover

\begin{tabular}{|c|c|}
\hline BMP Type: & $\begin{array}{l}\text { Retention/ Detention - } \\
\text { Linear }\end{array}$ \\
\hline $\begin{array}{l}\text { TSS Removal: } \\
\text { Nitrogen Removal: }\end{array}$ & $\begin{array}{l}30-90 \% \\
0-50 \%\end{array}$ \\
\hline $\begin{array}{l}\text { Phosphorous } \\
\text { Removal. }\end{array}$ & $20-85 \%$ \\
\hline $\begin{array}{l}\text { Metal Removal: } \\
\text { E. coli Removal: }\end{array}$ & $\begin{array}{l}0-90 \% \\
\text { N/A }\end{array}$ \\
\hline $\begin{array}{l}\text { Runoff Volume } \\
\text { Control: }\end{array}$ & Low \\
\hline Runoff Rate Control: & Medium \\
\hline $\begin{array}{l}\text { Annual Maintenance } \\
\text { Cost: }\end{array}$ & $3-5 \%^{1}$ \\
\hline $\begin{array}{l}\text { Relative Construction } \\
\text { Cost: }\end{array}$ & Low \\
\hline Effective Life: & $5-20$ years \\
\hline
\end{tabular}

${ }^{1}$ Reported as a Percentage of Construction Cost

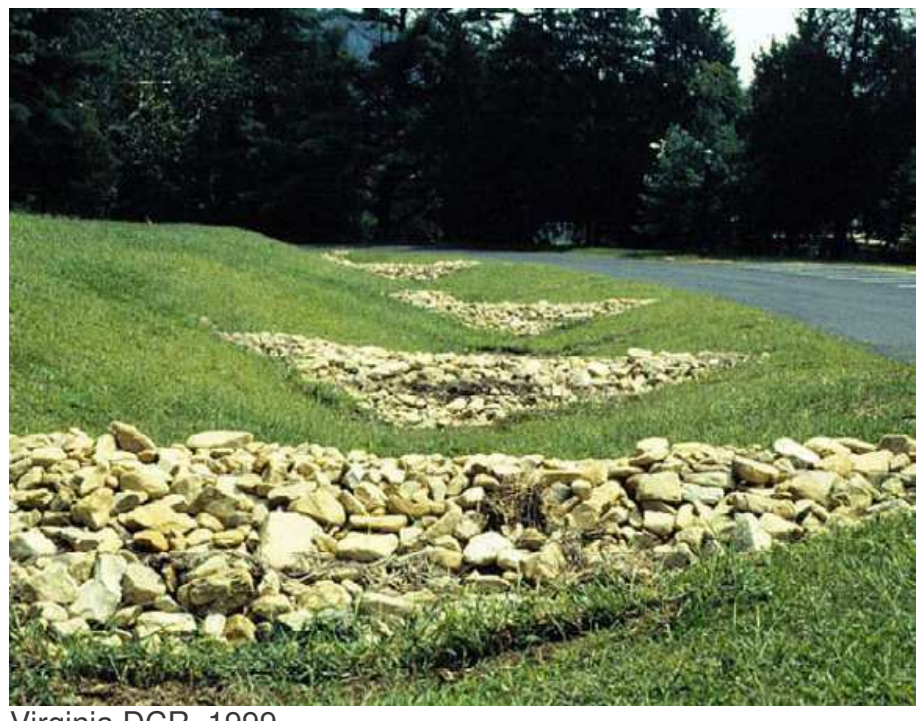

Virginia DCR, 1999 


\section{Dry Swale}

\section{Description:}

Dry swales are engineered grassed channels that not only convey stormwater from a roadway but also provide water quality benefits. They can be sized to detain stormwater and address water quantity management needs. Dry swales are designed so that runoff infiltrates through the bottom of the swale into the ground below. The majority of the treatment is provided by the process of soil infiltration, which filters suspended solids and facilitates adsorption of dissolved pollutants. The subsoil must have appropriate permeability and infiltration rates. Treatment efficiency of dry swale designs is dependent on the gradient of the swale, the swale size, and the infiltration rate of the subsoils.

Swales are configured as on-line facilities. They provide effective treatment of small, frequent storms, but must still retain the ability to convey high runoff rates from the roadway when less frequent highintensity storms occur. During these larger rainfall events, swales provide only marginal treatment of the high flow rates.

\section{Drawings:}

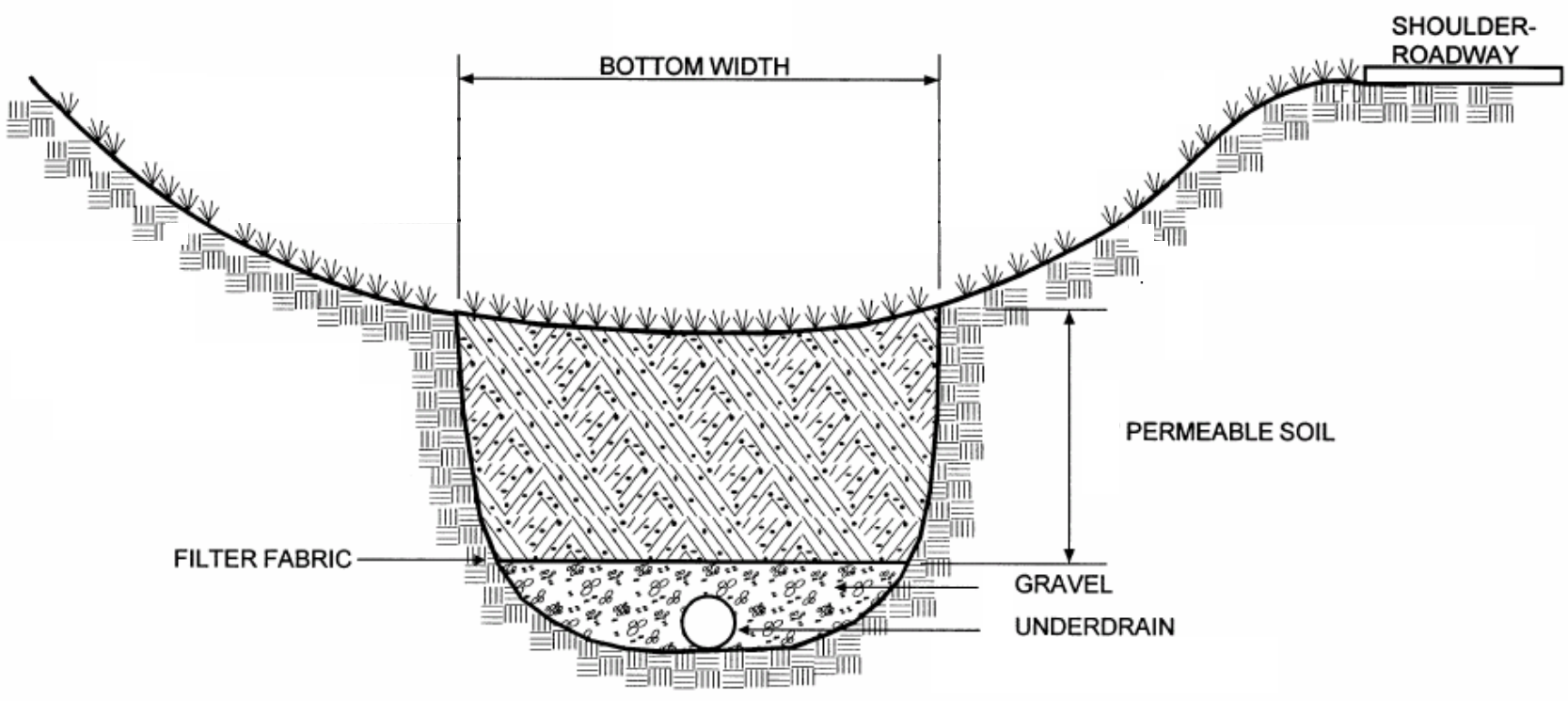

Figure 1: Typical Swale Configuration - Section View (Modified From Center for Watershed Protection) 


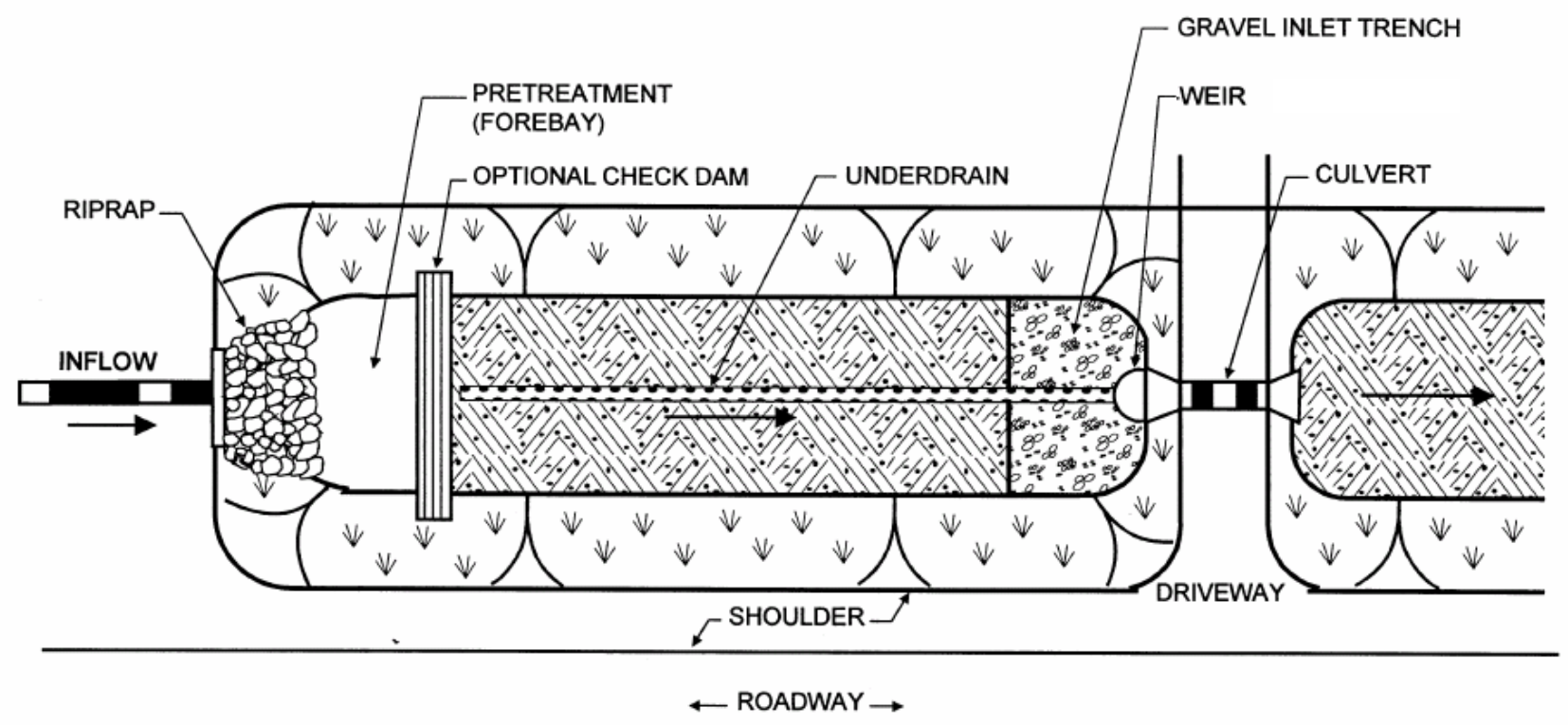

Figure 2: Typical Swale Configuration - Plan View (Modified From Center for Watershed Protection)

\section{References:}

Center for Watershed Protection, Stormwater Manager's Resources Center, 2005, Stormwater Management Fact Sheet, Grassed Channel.

http://www.stormwatercenter.net/

Virginia DCR, 1999. Virginia Stormwater Management Handbook. Commonwealth of Virginia, Department of Conservation and Recreation.

http://www.dcr.state.va.us/sw/stormwat.htm\#handbook 


\section{INDIANA DEPARTMENT OF TRANSPORTATION}

\section{Stormwater Quality Best Management Practices}

Post-Construction Stormwater Treatment

\section{Stormwater Wetland}

\section{When to use:}

- Any soil type

- In low lying areas

- Water table at the surface of the proposed wetland bottom elevation.

- Drainage area a minimum of 1 acre.

- Hydraulic head of 1 to 8 feet.

- Not practical for use in ultra urban settings.

\section{Advantages:}

- Medium construction cost.

- Low to moderate maintenance cost.

- Moderate to high community acceptance.

- Provides water quantity benefit in the form of runoff rate control.

- High wildlife habitat benefit.

- Has long effective life.

- Can be used as a regional water quality facility.

- May be possible to use existing native seedbank (dormant seeds present in topsoil) in lieu of seeding

\section{Limitations:}

- Requires additional right-of-way beyond standard clear zone limits

- Does not achieve 80\% TSS removal rates as a stand alone BMP but can be used in conjunction with other BMPs to achieve $80 \%$

- Minimum set-back from high water level required (see local codes)

- Can not accept pollutants from offsite hotspots

- Can accumulate salts and scum which can be flushed out by large storm flows

- Maintenance, including plant harvesting, is required to provide nutrient removal

- Wetland may periodically become a nutrient source
- Hydrology must be adequate to sustain wetland vegetation.

- If native seedbank is inadequate, a qualified professional must select vegetation.

\begin{tabular}{||ll||}
\hline \hline & \\
BMP Type: & Constructed Wetland - \\
TSS Removal: & Linear \\
Nitrogen Removal: & $65 \%$ \\
Phosphorous & $20 \%$ \\
Removal: & $25 \%$ \\
Metal Removal: & $35-65 \%$ \\
E. coli Removal: & N/A \\
Runoff Volume & Low \\
Control: & High \\
Runoff Rate Control: & $5-7 \%{ }^{1}$ \\
Annual Maintenance & \\
Cost: & Medium \\
Relative Construction & Most: \\
Coffective Life: & $20-50$ years \\
\hline \hline
\end{tabular}

Reported as a percentage of Construction Cost

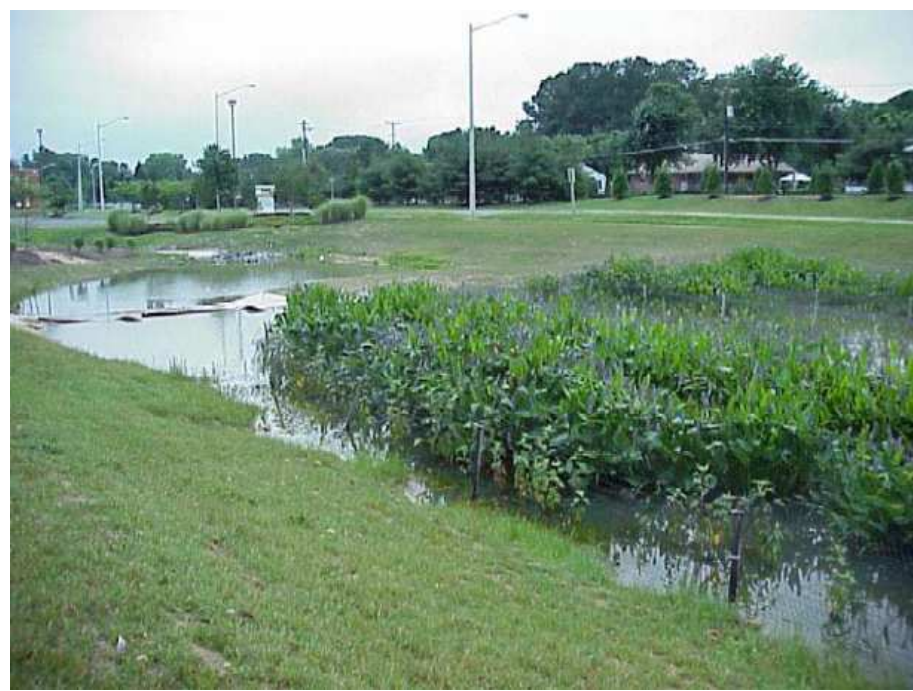

Virginia DCR, 1999 


\section{Stormwater Wetlands}

\section{Description:}

Stormwater wetlands are constructed wetland systems designed to maximize the removal of pollutants from stormwater runoff via several mechanisms: microbial breakdown of pollutants, plant uptake, retention, settling and adsorption. Stormwater wetlands temporarily store runoff in shallow pools that support conditions suitable for the growth of wetland plants. Stormwater wetlands also promote the growth of microbial populations which can extract soluble carbon and nutrients and potentially reduce BOD and fecal coliform levels concentrations.

Stormwater quality wetlands differ from wetlands constructed for compensatory mitigation purposes and wetlands created for restoration. Typically, stormwater wetlands will not have the full range of ecological functions of natural wetlands; stormwater wetlands are designed specifically for flood control and water quality purposes. Similar to wet ponds, stormwater wetlands require relatively large contributing drainage areas and/or dry weather base flow.

\section{Drawings:}

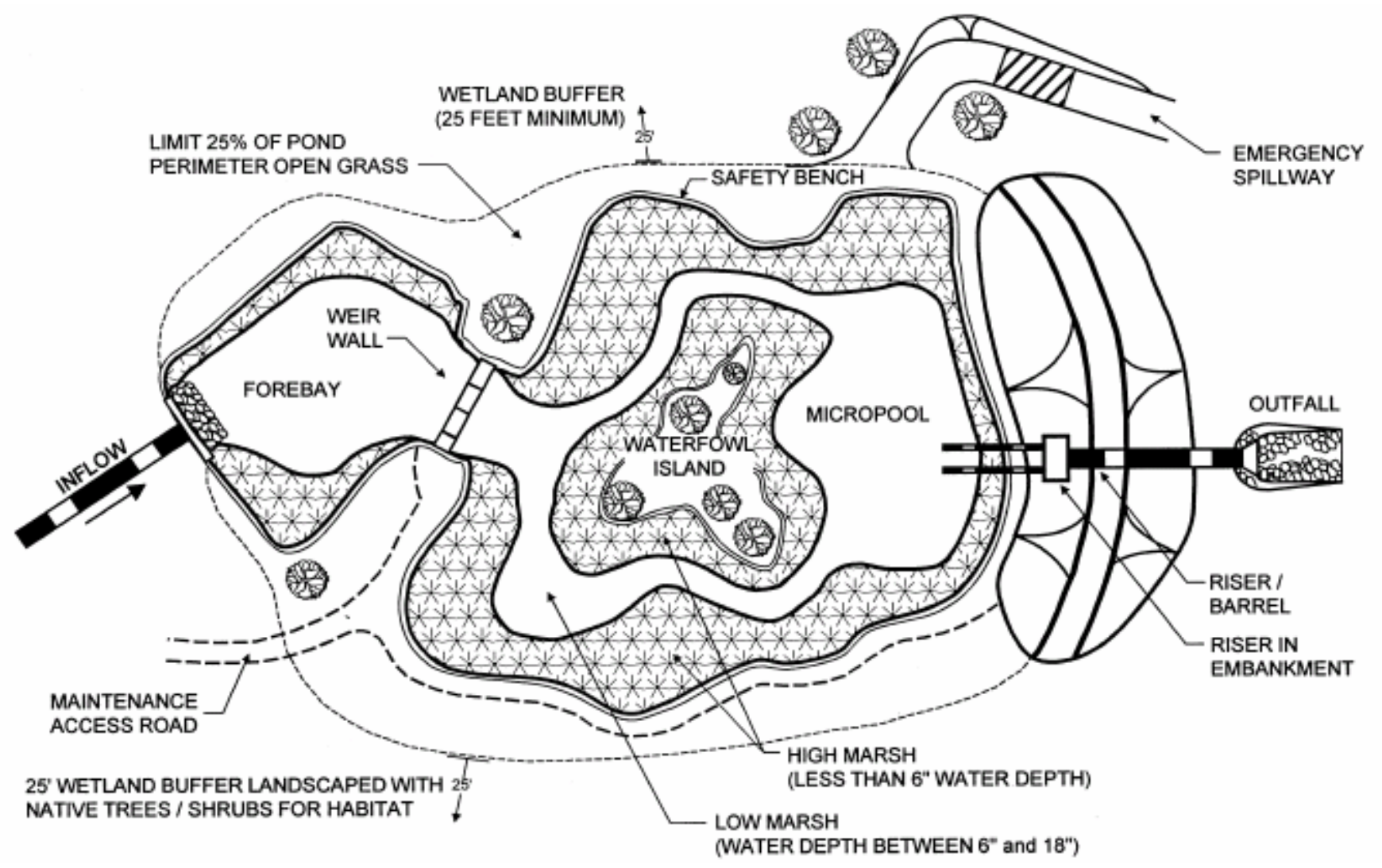

Figure 1: Constructed wetland plan view

(Georgia Stormwater Management Manual, 2001) 


\section{Stormwater Wetlands}

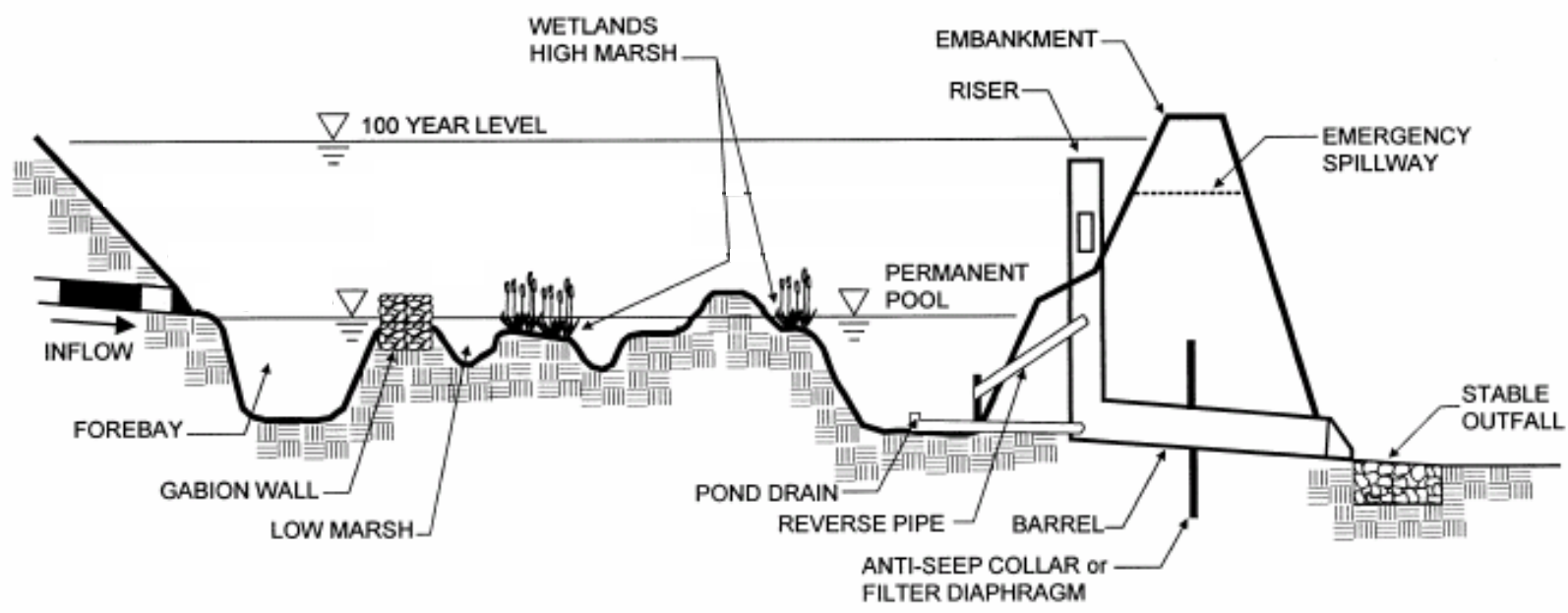

Figure 2: Constructed wetland section view (Georgia Stormwater Management Manual, 2001)

\section{References:}

Georgia Stormwater Management Manual, 2001. Volume 2, Section 3.2.1. http://www.georgiastormwater.com/

Metropolitan Council, 2001. Minnesota Urban Small Sites BMP Manual, Stormwater Best Management Practices for Cold Climates. Metropolitan Council Environmental Services. http://www.metrocouncil.org/environment/Watershed/BMP/manual.htm

Virginia DCR, 1999. Virginia Stormwater Management Handbook. Commonwealth of Virginia, Department of Conservation and Recreation.

http://www.dcr.state.va.us/sw/stormwat.htm\#handbook 


\section{INDIANA DEPARTMENT OF TRANSPORTATION}

\section{Stormwater Quality Best Management Practices}

Post-Construction Stormwater Treatment

\section{Wet Swale}

\section{When to use:}

- Any soil type

- Moderately sloping terrain

- Water table elevation is at the swale invert elevation

- Drainage area of 2 to 4 acres

- Hydraulic head of 2 to 3 feet

- Not practical for use in ultra urban settings

\section{Advantages:}

- Medium construction cost

- Moderate community acceptance

- Medium wildlife habitat benefit

- Relatively easy to design, install and maintain

\section{Limitations:}

- Does not achieve $80 \%$ TSS removal rates as a stand alone BMP but can be used in conjunction with other BMPs to achieve $80 \%$

\section{BMP Type:}

TSS Removal:

Nitrogen Removal:

Phosphorous Removal:

Metal Removal:

E. coli Removal:

Runoff Volume Control:

Runoff Rate Control:

Annual Maintenance

Cost:

Relative Construction

Cost:

Effective Life:
Constructed

Wetland - Linear

$65 \%$

$20 \%$

$25 \%$

$35-65 \%$

$\mathrm{N} / \mathrm{A}$

Low

Low

$5-20 \%{ }^{1}$

Medium

5-20 years

${ }^{1}$ Reported as a percentage of Construction Cost

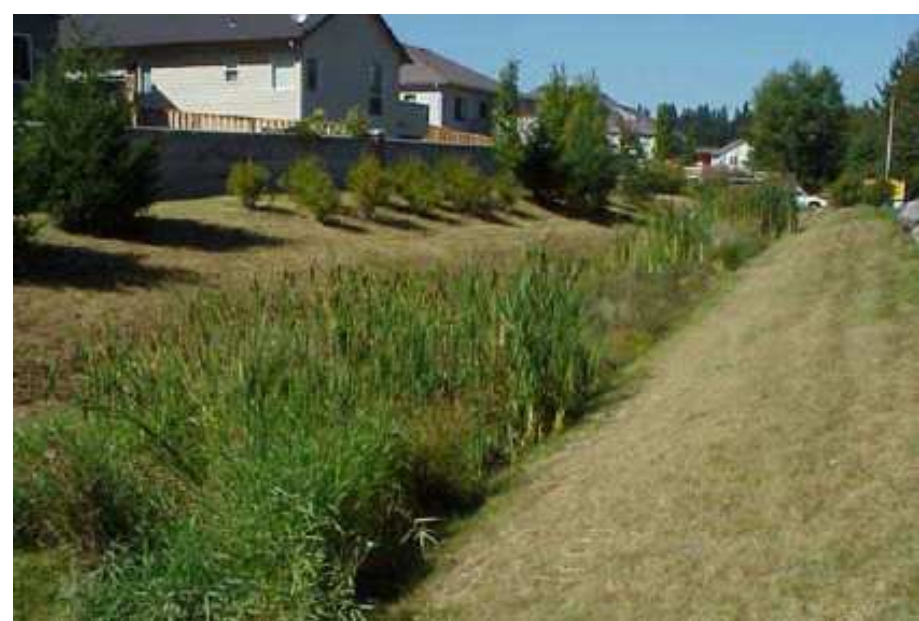

PA SW Management Manual, 2005 required (see local codes)

- Variable maintenance cost

- Can not handle pollutants from offsite hotspots

- Additional design criteria necessary to achieve runoff quantity control

- Can have a short effective life even with appropriate maintenance.

- Potential for mosquito breeding areas

- Not appropriate for pollutants toxic to vegetation

- Become less feasible as number of culvert crossing increase 


\section{Wet Swale}

\section{Description:}

Wet swales are engineered grassed channels that not only convey stormwater from a roadway but also provide water quality benefits. Wet swales are distinguished from the simple drainage/grassed channel by design features that maintain a saturated condition in soils at the bottom of the swale. The goal of a wet swale is to create an elongated wetland treatment system that treats stormwater through physical and biological action. Unlike dry swales, infiltration of stormwater is an undesirable condition in a wet swale because it would likely result in conditions detrimental to maintaining saturated soils to support wetland vegetation. Wet swales provide for stormwater treatment in wet soils where treatment may otherwise be nonexistent or negligible. Versatility with this practice allows for off-line placement of wetland cells, as well as the introduction of emergent wetland plant species to encourage creation of habitat. Wet swales can also be sized to detain stormwater and address water quantity management needs.

\section{Drawings:}

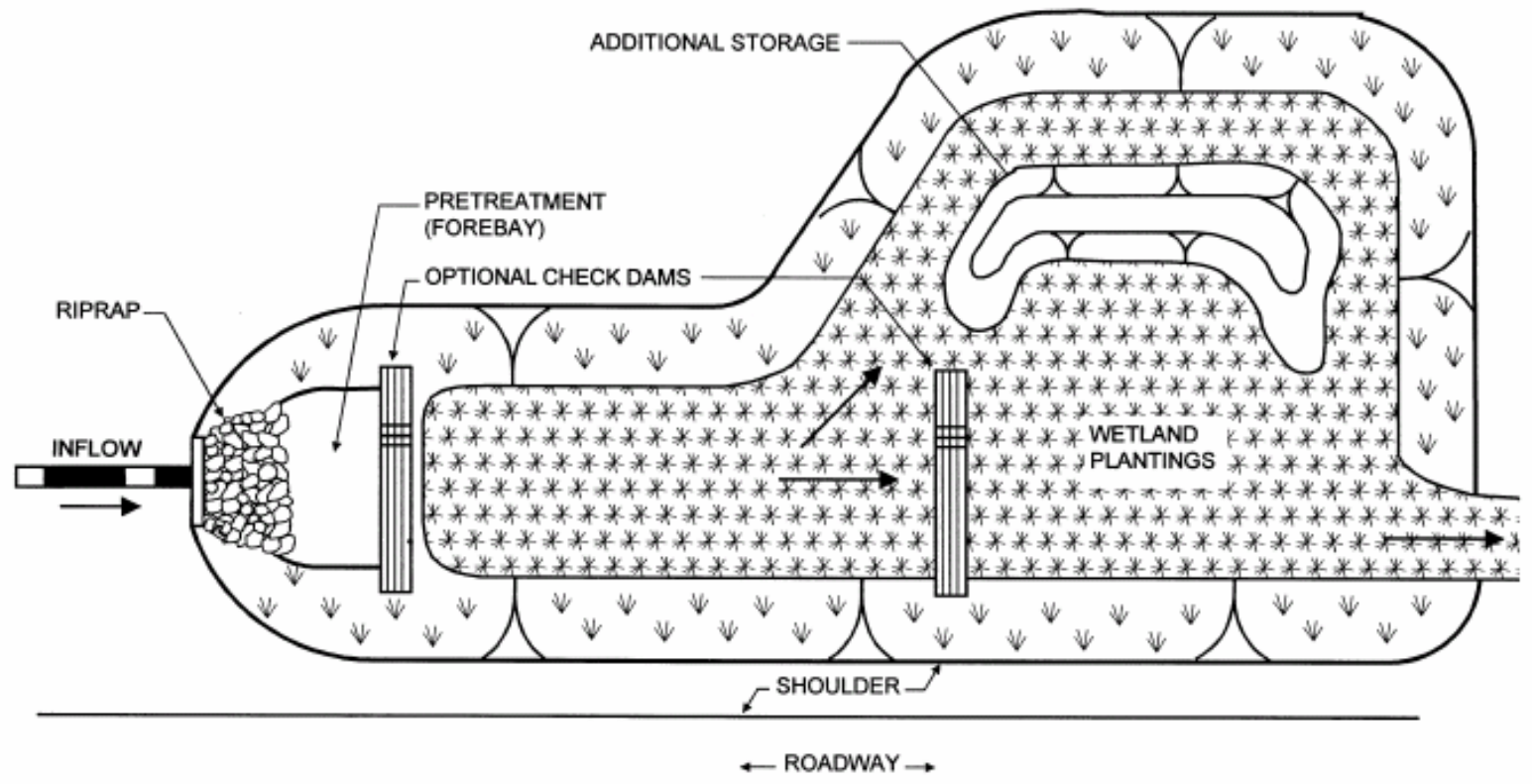

Figure 1: Plan View of a Wet Swale (Center for Watershed Protection)

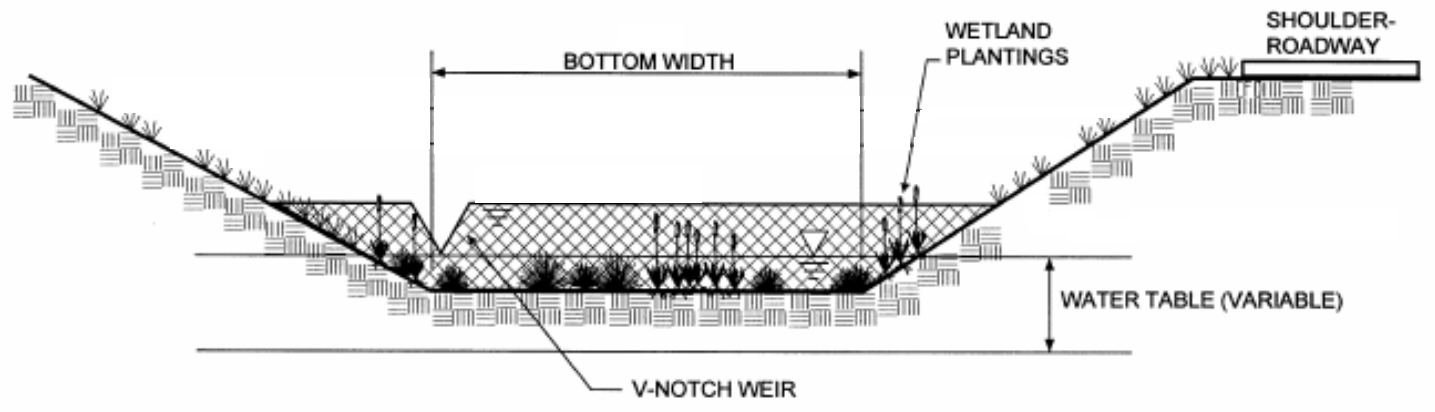

Figure 2: Section view of a wet swale with optional check dam (Modified from Center for Watershed Protection) 


\section{Wet Swale}

\section{References:}

Center for Watershed Protection, Stormwater Manager's Resources Center, 2005, Stormwater Management Fact Sheet, Grassed Channel.

http://www.stormwatercenter.net/

PADEP, 2005. Draft Pennsylvania Stormwater Management Manual, Section 6. Pennsylvania Department of Environmental Protection.

http://www.dep.state.pa.us/dep/subject/advcoun/stormwater/Manual DraftJan05/Section06-StructuralBMPs-part1.pdf 


\section{INDIANA DEPARTMENT OF TRANSPORTATION}

Stormwater Quality Best Management Practices

Post-Construction Stormwater Treatment

\section{Infiltration Trench}

\section{When to use:}

- Should not used in karst areas

- In soil types A and B

- Water table is at least 3 feet below the trench

- Drainage area of 2 to 4 acres

- Hydraulic head of 3 to 8 feet

- Can be used in some ultra urban settings

\section{Advantages:}

- Can achieve $80 \%$ TSS removal rates as a stand alone BMP

- Highly efficient removal of pollutants of concern

- Low to moderate maintenance cost

- Moderate to high community acceptance

- Provides water quantity benefit in the form of runoff volume control

- Provides groundwater recharge

\section{Limitations:}

- High construction cost

- Can not accept pollutants from offsite hotspots

- Can have a short effective life even with appropriate maintenance

- High failure rate due to clogging and high maintenance burden

- Low removal of dissolved pollutants in very coarse soils

- Groundwater monitoring may be needed due to risk of contamination in very coarse soils

- Metal and petroleum hydrocarbons can accumulate in soils to potentially toxic levels

- No wildlife habitat benefit

- Pretreatment of runoff is recommended to minimize sediment loading, avoid clogging. TSS removal

\begin{tabular}{||ll||}
\hline \hline & \\
BMP Type: & $\begin{array}{l}\text { Infiltration System - } \\
\text { Linear }\end{array}$ \\
TSS Removal: & $75-99 \%$ \\
Nitrogen Removal: & $45-70 \%$ \\
Phosphorous & $50-75 \%$ \\
Removal: & $75-99 \%$ \\
Metal Removal: & $75-98 \%$ \\
E. coli Removal: & High \\
Runoff Volume & Medium \\
Control: & $5-7 \% 1$ \\
Runoff Rate Control: & Annual Maintenance \\
Cost: & High \\
Relative Construction \\
Cost: & $5-15$ years \\
Effective Life: & \\
\hline \hline
\end{tabular}

${ }^{1}$ Reported as a percentage of Construction Cost

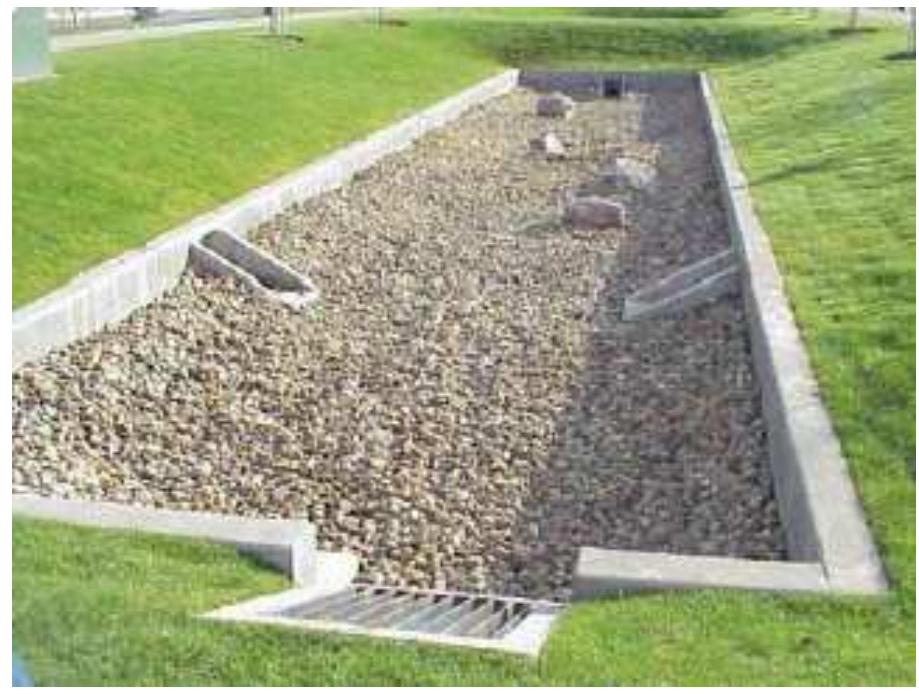

Portland, OR BMP Manual, 2004 


\section{Description:}

An infiltration trench is an excavated trench that has been lined and backfilled with stone to form a subsurface basin. Stormwater runoff is diverted into the trench and is stored until it can infiltrate into the soil, usually over a period of several days. Infiltration trenches are very adaptable BMPs, and the availability of many practical configurations make it ideal for small urban drainage areas, such as ultra-urban sites. Infiltration trenches can be either on-line or off-line systems. They are most effective and have a longer life cycle when some type of pretreatment to remove sediment is included in their design. Pretreatment may include techniques such as vegetated filter strips or grassed swales.

Infiltration trenches provide the majority of treatment by processes related to soil infiltration, which include sorption, precipitation, trapping, filtering, and bacterial degradation..

\section{Drawings:}

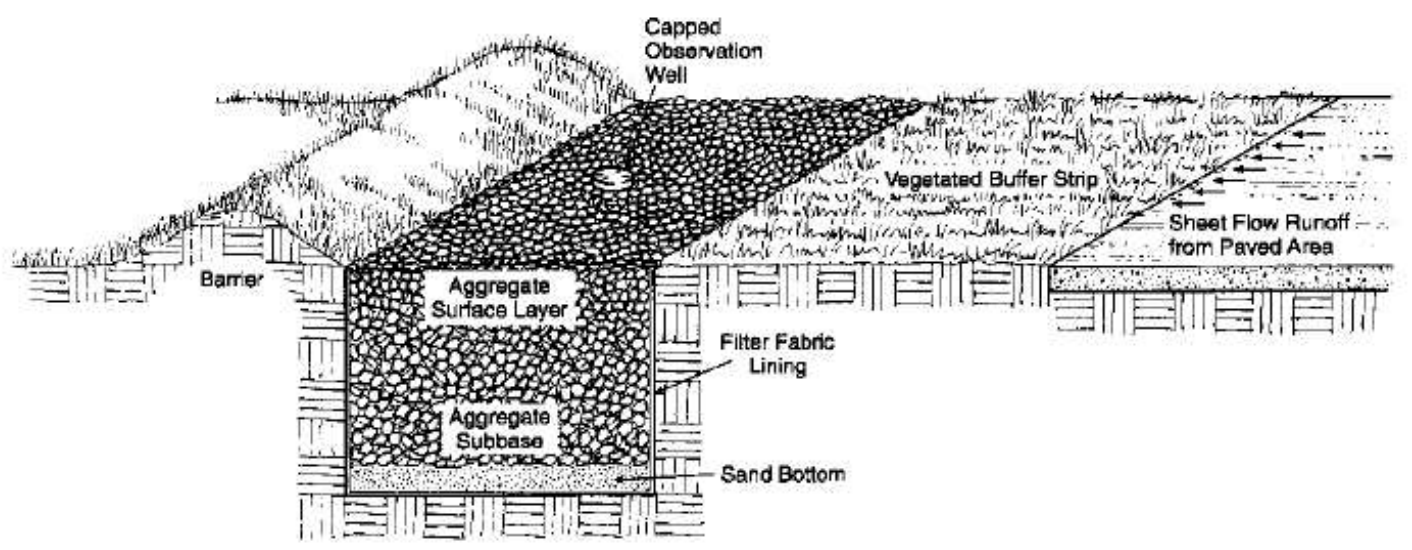

Figure 1: Typical Above Ground Infiltration trench Configuration (Modified from Georgia Stormwater Management Manual, 2001 


\section{Infiltration Trench}

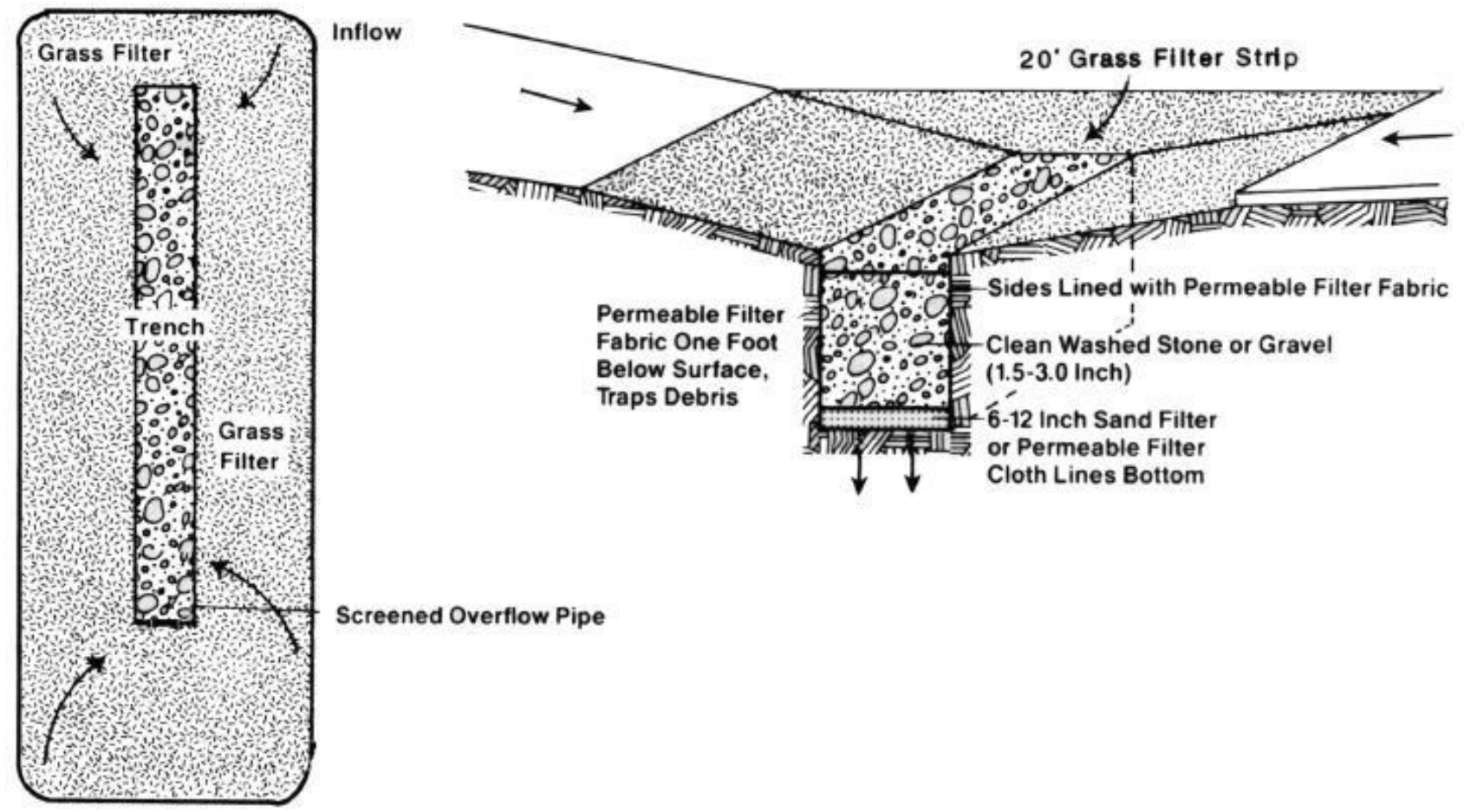

Figure 2: Infiltration Trench, Road Median Application - Plan and Section View (Metropolitan Council, 2001)

\section{References:}

Georgia Stormwater Management Manual, 2001. Volume 2, Section 3.2.1.

http://www.georgiastormwater.com/

Metropolitan Council, 2001. Minnesota Urban Small Sites BMP Manual, Stormwater Best Management Practices for Cold Climates. Metropolitan Council Environmental Services. http://www.metrocouncil.org/environment/Watershed/BMP/manual.htm

Portland, Oregon Bureau of Environmental Services, 2004, Portland Stormwater Management Manual.

http://www.portlandonline.com/bes/index.cfm 


\section{INDIANA DEPARTMENT OF TRANSPORTATION}

\section{Stormwater Quality Best Management Practices}

Post-Construction Stormwater Treatment

\section{Infiltration Basin}

\section{When to use:}

- Should not be used in karst areas

- In soil types A and B

- Water table is at least 3 feet below the basin

- Drainage area of 2 to 20 acres

- Hydraulic head of 3 to 4 feet

- Not practical for use in ultra urban settings

\section{Advantages:}

- Can achieve $80 \%$ TSS removal rates as a stand alone BMP

- Highly efficient removal of pollutants of concern

- Medium construction cost

- Moderate community acceptance

- Provides water quantity benefit in the form of runoff volume control

- Provides groundwater recharge

\section{Limitations:}

- Requires additional right-of-way beyond standard clear zone limits

- Moderate to high maintenance cost

- Can not accept pollutants from offsite hotspots

- Can have a short effective life even with appropriate maintenance

- High failure rate due to clogging and high maintenance burden

- Low removal of dissolved pollutants in very coarse soils

- Groundwater monitoring may be needed due to risk of contamination in very coarse soils

- Metal and petroleum hydrocarbons can accumulate in soils to potentially toxic levels

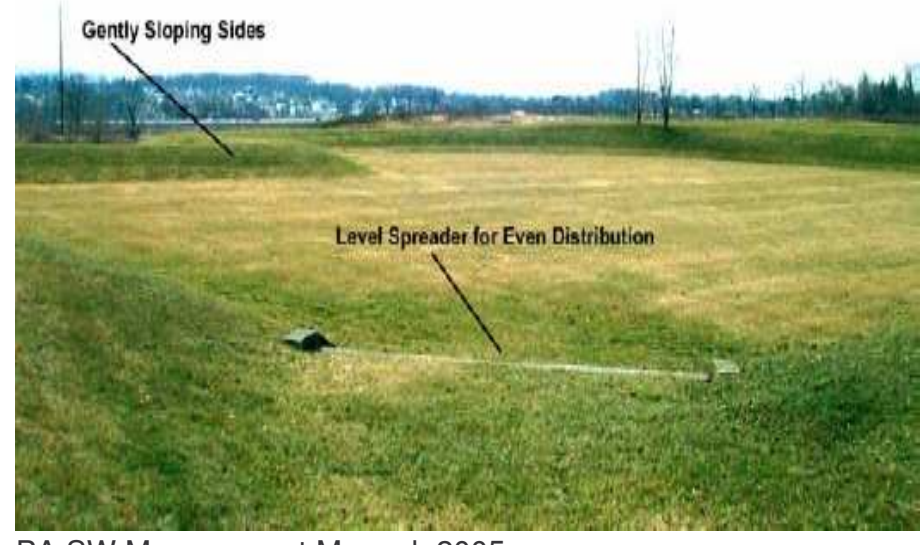

PA SW Management Manual, 2005
Infiltration System -

Non-Linear

$75-99 \%$

$45-70 \%$

$50-75 \%$

$50-90 \%$

$75-98 \%$

High

Control:

Runoff Rate Control: Medium

Annual Maintenance

Cost:

Relative Construction

Cost:

Effective Life:

5-15 years

- Requires relatively large amount of right-ofway compared to other measures

- Low wildlife habitat benefit unless vegetation with plantings other than turf grass 


\section{Infiltration Basin}

\section{Description:}

An infiltration basin is a surface pond which captures first-flush stormwater and treats it by allowing it to percolate into the ground through permeable soils. Physical, chemical, and biological processes occur within the soil column, which remove both sediments and soluble pollutants. Pollutants are trapped in the upper layers of the soil, and the water is then released to groundwater. Infiltration basins are generally used for drainage areas between 2 and 20 acres. For drainage areas less than 2 acres, an infiltration trench or other BMP may be more appropriate. For drainage areas greater than 20 acres, maintenance of an infiltration basin would be burdensome, and an dry extended detention basin or wet pond may be more appropriate. Infiltration basins are generally dry except immediately following storms, but a low-flow channel may be necessary if a constant base flow is present.

\section{Drawing:}

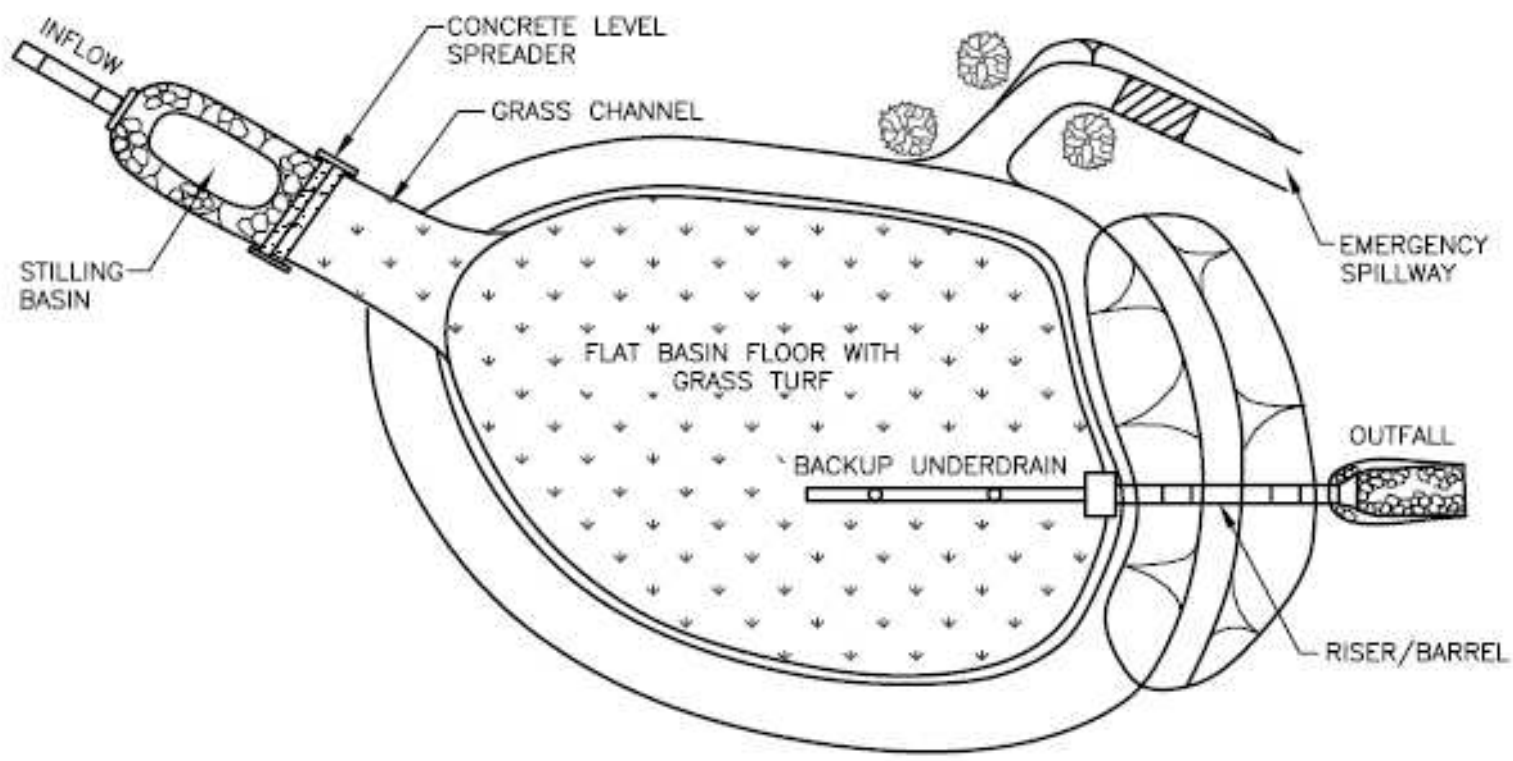

Figure 1 - Plan view of an infiltration basin

(PA SW Management Manual, 2005)

\section{Reference:}

PADEP, 2005. Draft Pennsylvania Stormwater Management Manual, Section 6. Pennsylvania Department of Environmental Protection.

http://www.dep.state.pa.us/dep/subject/advcoun/stormwater/Manual DraftJan05/Section06-StructuralBMPs-part1.pdf 


\section{INDIANA DEPARTMENT OF TRANSPORTATION}

Stormwater Quality Best Management Practices

Post-Construction Stormwater Treatment

\section{Bioretention}

\section{When to use:}

- Any soil type

- Low lying areas

- Water table is at least 3 feet below the swale invert

- Drainage area of 2 to 4 acres

- Hydraulic head of 2 to 3 feet

- Can be used in ultra urban settings

\section{Advantages:}

- Can accept pollutants from offsite hotspots

- Moderate maintenance cost

- Moderate community acceptance

- Medium wildlife habitat benefit

- Good metal removal rates

- Requires relatively little engineering design

- Provides groundwater recharge when runoff is allowed to infiltrate

- Also can serve as landscaping features

\section{Limitations:}

\begin{tabular}{|c|c|}
\hline BMP Type: & $\begin{array}{l}\text { Filtration System - } \\
\text { Linear }\end{array}$ \\
\hline TSS Removal: & $75 \%$ \\
\hline Phosphorous & $50 \%$ \\
\hline Removal: & $50 \%$ \\
\hline $\begin{array}{l}\text { Metal Removal: } \\
\text { E. coli Removal: }\end{array}$ & $\begin{array}{l}75-80 \% \\
\text { N/A }\end{array}$ \\
\hline $\begin{array}{l}\text { Runoff Volume } \\
\text { Control: }\end{array}$ & Medium \\
\hline Runoff Rate Control: & Medium \\
\hline $\begin{array}{l}\text { Annual Maintenance } \\
\text { Cost: }\end{array}$ & $5-7 \%^{1}$ \\
\hline $\begin{array}{l}\text { Relative Construction } \\
\text { Cost: }\end{array}$ & High \\
\hline Effective Life: & $5-20$ years \\
\hline
\end{tabular}

Reported as a percentage of Construction Cost

- Requires additional right-of-way beyond standard clear zone limits

- Does not achieve $80 \%$ TSS removal rate as a stand alone BMP but can be combined with other measures

- High construction cost

- Additional design criteria necessary to achieve runoff quantity control

- Can have a short effective life even with appropriate maintenance

- Low removal of nitrates

- Clogging may be a problem if the BMP receives runoff with high fine particle loads

- Maximum ponds depths may limit the amount of runoff that can be directed to the area

- Construction runoff should be diverted due to

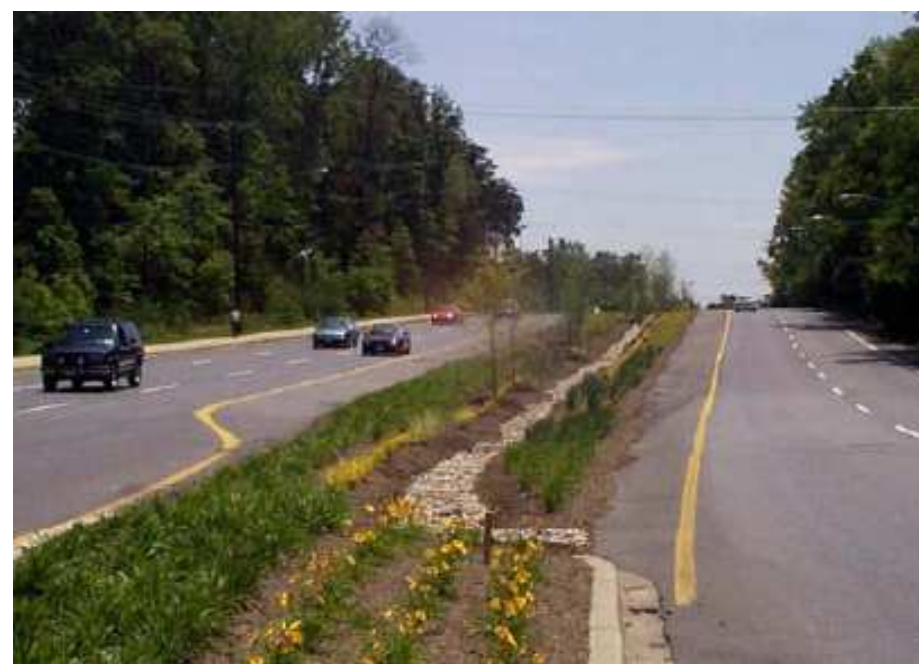

PA SW Management Manual, 2005 the clogging potential 


\section{Bioretention}

\section{Description:}

Bioretention can be described as shallow, landscaped depressions commonly located in parking lot islands, medians, or within small pockets in residential areas. Stormwater flows into the bioretention area, ponds on the surface, and gradually infiltrates into the soil bed. Pollutants are removed by a number of processes including adsorption, filtration, volatilization, ion exchange and decomposition. Filtered runoff can either be allowed to infiltrate into the surrounding soil, or collected by an underdrain system and discharged to the storm sewer system or directly to receiving waters. Infiltration components should not be incorporated into bioretention designs in karst areas. Runoff from larger storms is generally diverted past the area to the storm drain system.

\section{Drawing:}

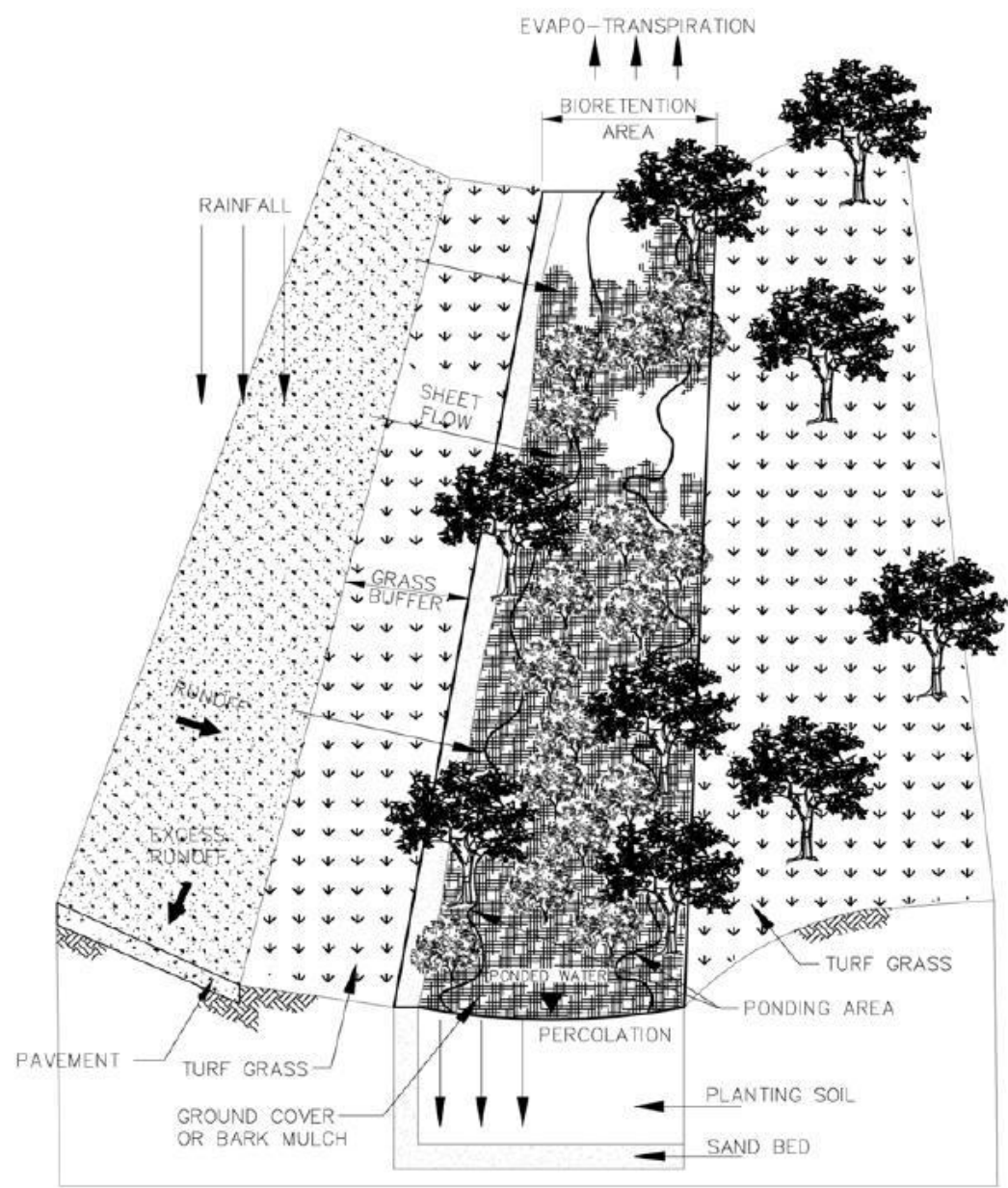

Figure 1: Bioretention Basin

\section{References:}

(Virginia DCR, 1999)

PADEP, 2005. Draft Pennsylvania Stormwater Management Manual, Section 6. Pennsylvania Department of Environmental Protection.

http://www.dep.state.pa.us/dep/subject/advcoun/stormwater/Manual DraftJan05/Section06-StructuralBMPs-part1.pdf

Virginia DCR, 1999. Virginia Stormwater Management Handbook. Commonwealth of Virginia, Department of Conservation and Recreation. 


\section{INDIANA DEPARTMENT OF TRANSPORTATION}

\section{Stormwater Quality Best Management Practices}

Post-Construction Stormwater Treatment

\section{Filter Strip}

\section{When to use:}

- Any soil type

- Moderately sloping terrain

- Water table is at least 3 feet below the filter strip

- Drainage area of less than 5 acres

- Where sheet flow can be achieved

- Not practical for use in ultra urban settings

\section{Advantages:}

- Can accept pollutants from offsite hotspots

- Low construction cost

- Low to moderate maintenance cost

- High community acceptance

- Medium wildlife habitat benefit

- Slightly reduces watershed imperviousness

- Slightly contributes to groundwater recharge

\section{Limitations:}

- Can not accept concentrated flow. Concentrated flow must be distributed with a level spreader.

- Does not achieve 80\% TSS removal rate as a stand alone BMP

- Additional measures necessary to achieve adequate runoff quantity control

- Removal rates vary widely depending on flow lengths

- Can have a short effective life even with appropriate maintenance

- Requires slopes less than $10 \%$

- Requires low to fair permeability of natural subsoil

- Requires more right-of-way than other BMPs

- Effectiveness significantly reduced if flow becomes concentrated

BMP Type:

TSS Removal:

Nitrogen Removal:

Phosphorous

Removal:

Metal Removal:

E. coli Removal:

Runoff Volume

Control:

Runoff Rate Control:

Annual Maintenance

Cost:

Relative Construction

Cost:

Effective Life:
Filtration System -

Linear

$27-70 \%$

$20-40 \%$

$20-40 \%$

$2-80 \%$

$\mathrm{N} / \mathrm{A}$

Medium

Medium

$5-7 \%{ }^{1}$

Low

10-20 years

Reported as a percentage of Construction Cost

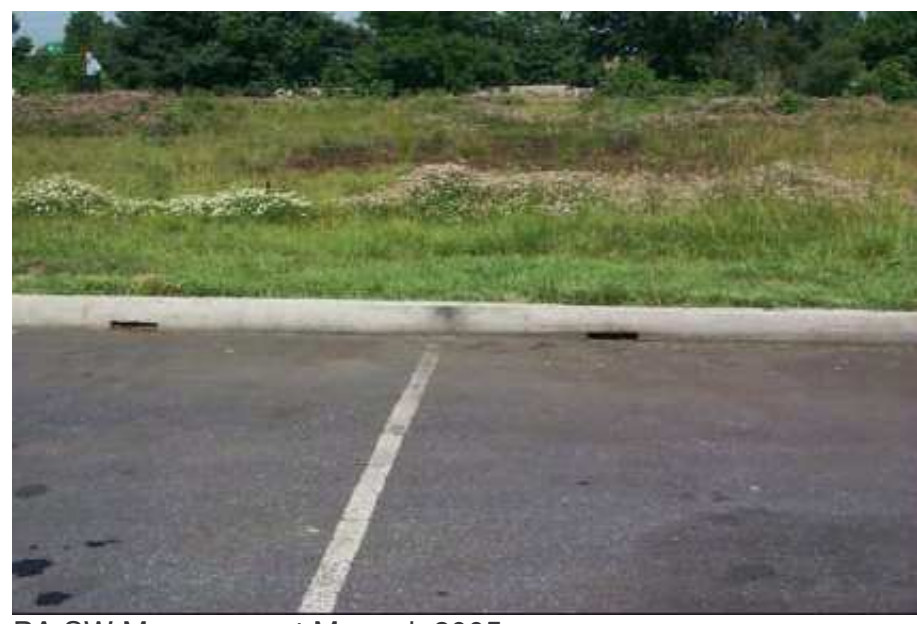

PA SW Management Manual, 2005

- Pollutant removal is unreliable in urban settings 


\section{Filter Strip}

\section{Description:}

Vegetated filter strips, also known as vegetated buffer strips, are vegetated areas with low slopes, designed to accept runoff as overland sheet flow. When used as erosion and sediment control during construction, filter strips are generally not engineered or constructed but rather areas where existing vegetation is preserved. Runoff velocity is reduced by maintaining existing vegetative cover and/or, preserving a natural buffer strip around the lower perimeter of the disturbed land. However, a vegetated filter strip is not an effective control alone and must be combined with other postconstruction BMPs.

This factsheet covers the use of engineered vegetated filter strips as a permanent control measure. Vegetated filter strips may range in form from grassland to forest, and are designed to intercept flow, lower flow velocity, and maintain sheet flow conditions. The dense vegetative cover facilitates conventional pollutant removal through detention, sedimentation, filtration by vegetation, and infiltration into soil. Existing vegetative buffers can be preserved during construction and function as post-construction BMPs.

Filter strips are most useful in contributing watershed areas where peak runoff velocities are low. In the ultra-urban environment, filter strips are limited due to the required flow length and are appropriate only where ample room exists for installation. There must be sufficient flow length and gradient to effectively treat the stormwater. The primary highway application for vegetative filter strips is along rural roadways where runoff that would otherwise discharge directly to a receiving water first passes through a filter strip before entering a conveyance system.

\section{Drawings:}

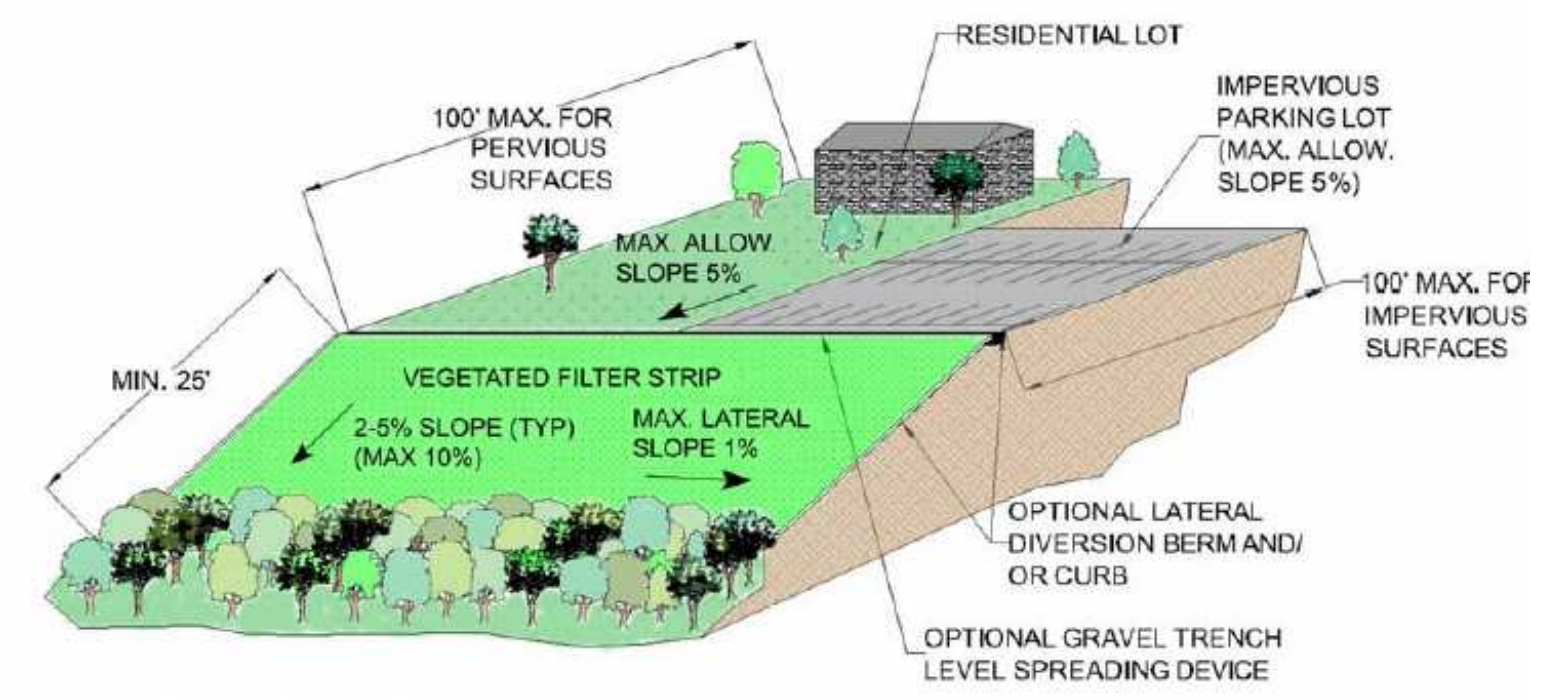

FILTER STRIP SLOPE ISA FUNCTION OF VEGETATIVE COVER, HYDROLOGIC SOIL GROUP, SOIL TYPE, AND SLOPE

Figure 1: Filter Strip - Isometric View

(PA SW Management Manual, 2005) 


\section{Filter Strip}

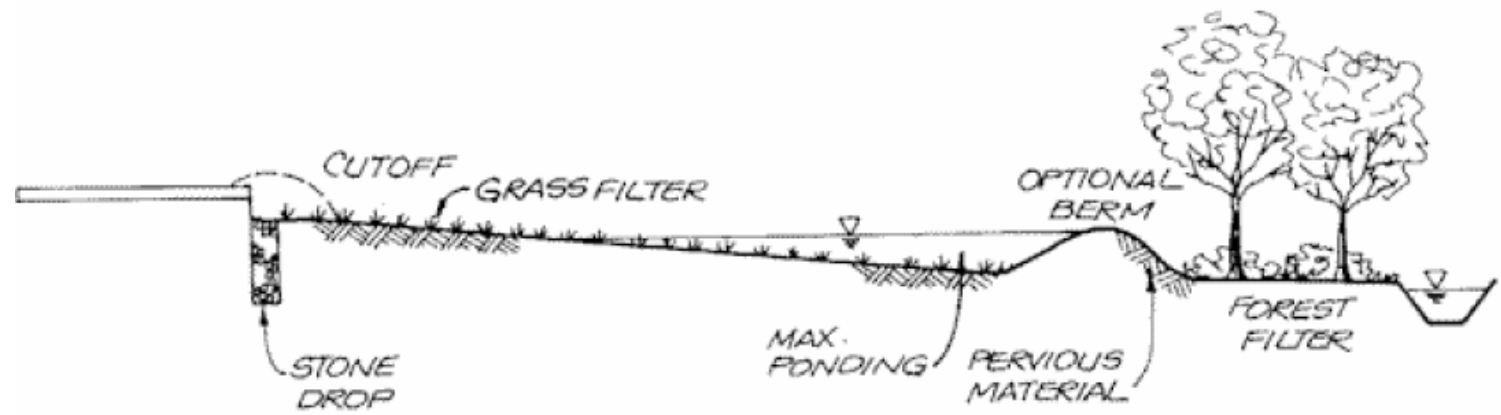

Figure 2: Filter Strip modified for quantity control

(Metropolitan Council, 2001)

\section{References:}

PADEP, 2005. Draft Pennsylvania Stormwater Management Manual, Section 6. Pennsylvania Department of Environmental Protection.

http://www.dep.state.pa.us/dep/subject/advcoun/stormwater/Manual DraftJan05/Section06-StructuralBMPs-part1.pdf

Metropolitan Council, 2001. Minnesota Urban Small Sites BMP Manual, Stormwater Best Management Practices for Cold Climates. Metropolitan Council Environmental Services. http://www.metrocouncil.org/environment/Watershed/BMP/manual.htm 
INDIANA DEPARTMENT OF TRANSPORTATION
Stormwater Quality Best Management Practices
Post-Construction Stormwater Treatment
Turf Reinforcement Mat

\section{When to use:}

- Any soil type

- Moderately sloping terrain

- Along channel banks, on slopes, or as a lining on intermittent drainage ways

- Can be used in ultra urban settings

\section{Advantages:}

- Can accept pollutants from offsite hotspots

- Low construction cost

- Low maintenance cost

- Moderate community acceptance

- Can increase the effectiveness of other water quality measures

\section{Limitations:}

- Increased probability of failure if not installed properly

- Very steep or unstable streambanks require close examination of the underlying soils for stability. May be combined with other bioengineering practices

- Turf reinforcement mats (TRMs) should not be considered to be a stand alone postconstruction BMPs. Installation of TRMs can be incorporated into other BMPs, such wet or dry swales.

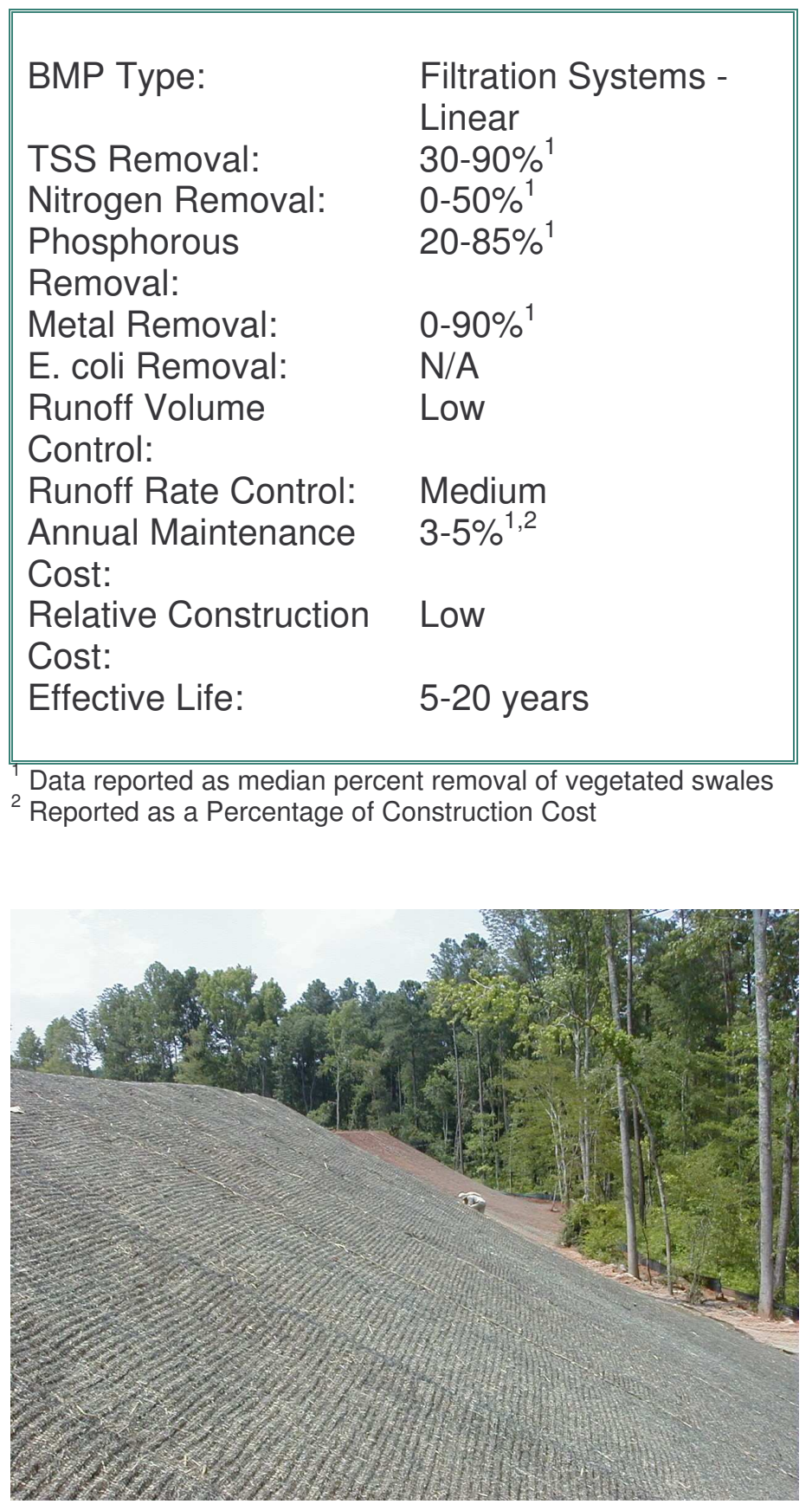

North American Green, undated 


\section{Turf Reinforcement Mat}

\section{Description:}

Turf reinforcement mats (TRMs) are three dimensional reinforcement matrices that provide sufficient thickness, strength and void space to permit soil filling and/or retention and the development of vegetation within the matrix. TRMs are composed of UV stabilized, non-degradable, synthetic fibers or nettings. Some TRMs also include a biodegradable component to promote vegetation growth. The medium of soil, vegetation, and fiber is designed for permanent and critical hydraulic applications where design discharges exert velocities and shear stresses that exceed the limits of mature, natural vegetation. TRMs should be designed based on allowable shear stress of the channel lining. The primary benefit of TRMs is they allow for infiltration and they can filter runoff from smaller rainfall events once vegetated.

\section{Drawings:}

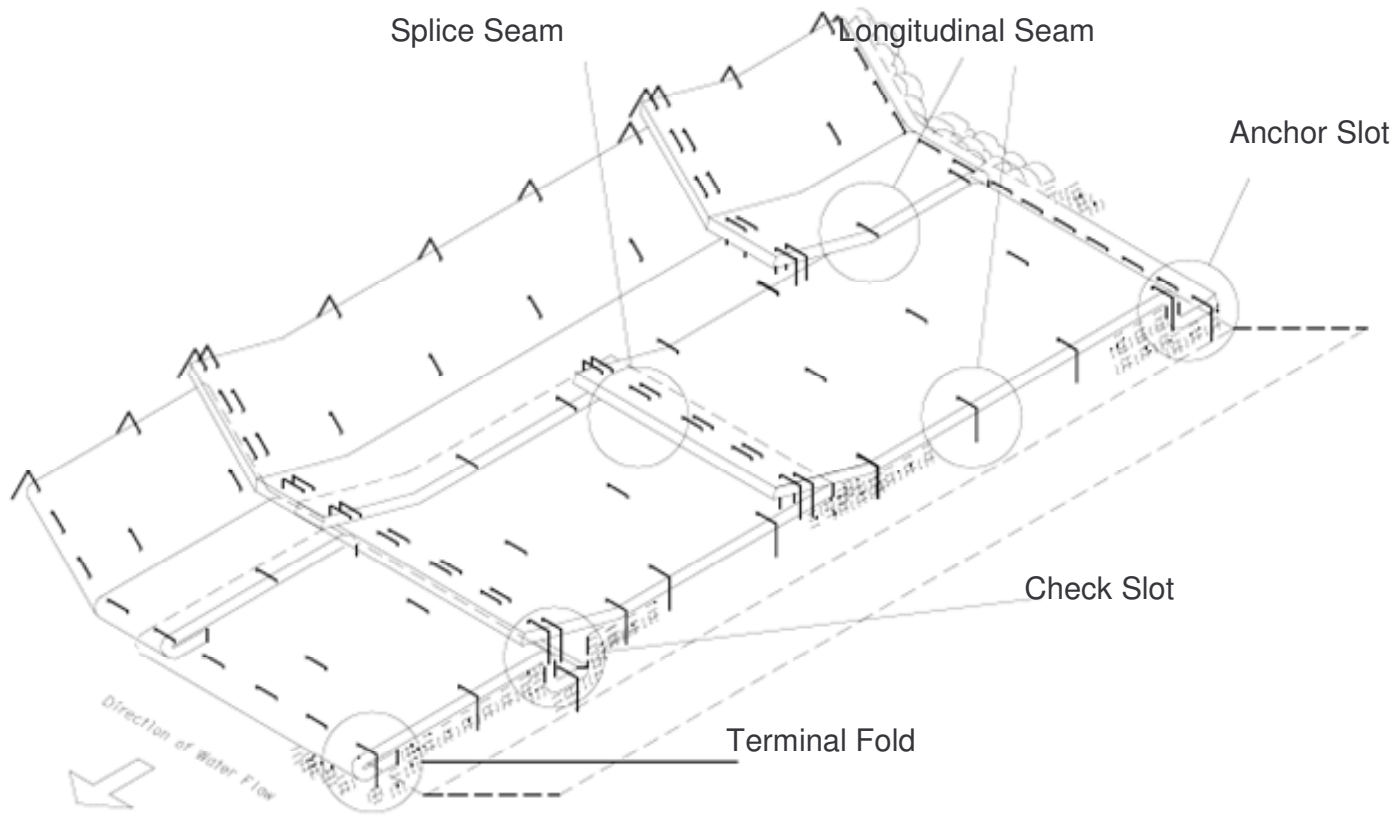

Figure 1: Channel Application

(TDOT, 2005)

\section{References:}

North American Green Image Library

http://www.nagreen.com/resources/imagelibrary/SC250/SC250 Slope Unveg.jpg

TDOT, 2005. Tennessee Department of Transportation Standard Drawings - Erosion Control and Landscaping. Tennessee Department of Transportation Design Division.

http://www.tdot.state.tn.us/Chief Engineer/engr library/design/Std Drwg Eng.HTM 


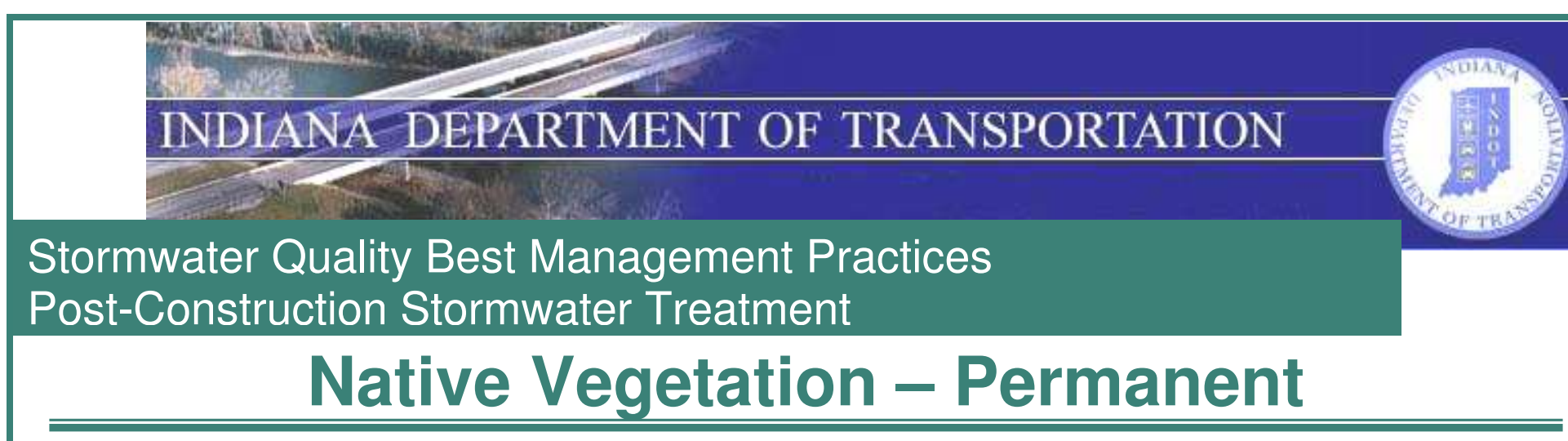

\section{When to use:}

- For revegetation on completed construction jobs

- For landscaping

- For soil stabilization above the ordinary high water mark on channel banks and on slopes

- In combination with turf reinforcement mats and other bioengineering measures

- In combination with all other water quality measures that call for vegetative components

\section{Advantages:}

- Maintenance limited to reseeding sparse or bare areas

- Native vegetation is better adapted to local conditions than non-native

- Aesthetically pleasing

- Can increase the effectiveness of other water quality measures

\section{Limitations:}

- Very steep or unstable streambanks require close examination of the underlying soils for stability. May be combined with other bioengineering practices

- Native seeding should not be considered to be a stand alone post-construction BMPs. Native seeding can be incorporated into other BMPs, such wet or dry swales, or anywhere else that revegetation is required

\begin{tabular}{|ll|}
\hline BMP Type: & $\begin{array}{l}\text { Retention/ Detention - } \\
\text { Linear }\end{array}$ \\
TSS Removal: & $30-90 \%^{1}$ \\
Nitrogen Removal: & $0-50 \%^{1}$ \\
Phosphorous & $20-85 \%^{1}$ \\
Removal: & \\
Metal Removal: & $0-90 \%^{1}$ \\
$\begin{array}{l}\text { E. coli Removal: } \\
\text { Runoff Volume }\end{array}$ & $\mathrm{N} / \mathrm{A}$ \\
$\begin{array}{l}\text { Control: } \\
\text { Runoff Rate Control: } \\
\text { Annual Maintenance }\end{array}$ & Low \\
Cost: & $3-5 \%{ }^{1,2}$ \\
Relative Construction & Low \\
Cost: & \\
Effective Life: & $5-20$ years \\
\hline Data reported as median percent removal of vegetated swales \\
\hline Reported as a Percentage of Construction Cost
\end{tabular}

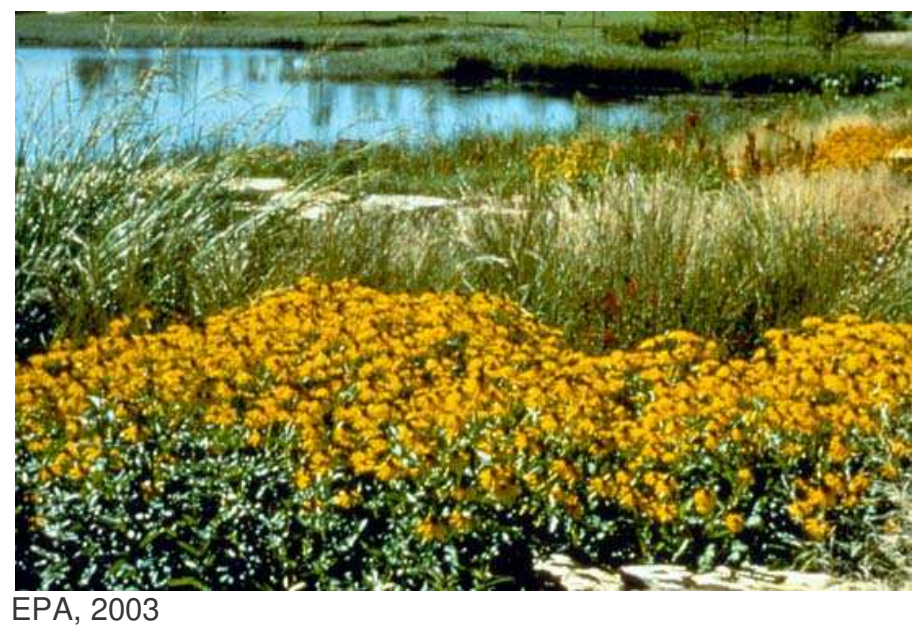




\section{Native Vegetation - Permanent}

\section{Description:}

Where possible, vegetative measures are preferred to engineered, structural, soil stabilization. On steeper slopes or flow paths, vegetation can be combined with turf reinforcement mats, fiber wattles, or other bioengineering techniques to aid in establishment and stability. The use of vegetative measures requires less maintenance and provides wildlife habitat.

Grasses introduced from Europe and Asia have traditionally been used to establish vegetative cover on construction sites in the Midwest. However, many designers are now specifying native grasses for revegetation, stabilization, and landscaping. Although slower to establish, native species require less maintenance in the long run than nonnative species. They are also better for water quality because they do not require the heavy fertilizer application that introduced species require.

Native grasses will grow on poor soils because they can gain access to nutrients and water that shallower-rooted grasses cannot reach. Therefore, native grasses are desirable for stabilizing soils. Cover crops such as oats or winter wheat should be seeded with native grasses to provide short-term erosion control while they are becoming established. Wildflowers could be added to the seed mixes on many projects. Because they develop very deep root systems, native grasses and wildflowers provide very good long-term erosion control.

References:

EPA Website, 2004. United States Environmental Protection Agency. Great Lakes Environment, Greenacres, Natural Landscaping Tool Kit, THE NATURAL LANDSCAPING ALTERNATIVE: An Annotated Slide Collection - Slide 7

http://www.epa.gov/greenacres/tooltestkit/gallary/TKSlide07.html 
INDIANA DEPARTMENT OF TRANSPORTATION
Stormwater Quality Best Management Practices
Post-Construction Stormwater Treatment
Hydrodvanic Separators

\section{When to use:}

- Any soil type

- Any terrain

- Water table greater than 3 feet below the structure

- Very practical for use in ultra urban settings

- Due to the increasing number of manufacturers of proprietary water quality structures, the upper limit of drainage area may vary from 2 to 300 acres.

\section{Advantages:}

- Achieves $80 \%$ or greater TSS removal rate as a stand alone measure

- Can accept pollutants from offsite hotspots

- High construction cost

- Low maintenance cost

- High community acceptance

- Very long effective life

- Prefabricated for different standard storm drain designs

- Require minimal space to install

\section{Limitations:}

- Does not provide runoff volume or rate control

- Removal rates for pollutants other than TSS vary by manufacturer and often depend on accessories added to the structure

- No wildlife habitat benefit

- Some devices may be vulnerable to accumulated sediments being resuspended during heavy storms

- Can only handle limited amounts of sediment and debris

- Regular maintenance and inspection is required to assess sediment, floatable, and oil accumulation

- Sizing and analysis vary between vendors

\begin{tabular}{ll} 
BMP Type: & Proprietary System - \\
& Linear \\
TSS Removal: & $80-90 \%$ \\
Nitrogen Removal: & N/A \\
Phosphorous & N/A \\
Removal: & \\
Metal Removal: & N/A \\
$\begin{array}{l}\text { E. coli Removal: } \\
\text { Runoff Volume }\end{array}$ & N/A \\
Control: & None \\
Runoff Rate Control: & None \\
Annual Maintenance & $1-5 \%$ \\
Cost: & \\
Relative Construction & High \\
Cost: & \\
Effective Life: & $>100$ years \\
& \\
\hline
\end{tabular}

Reported as a Percentage of Construction Cost

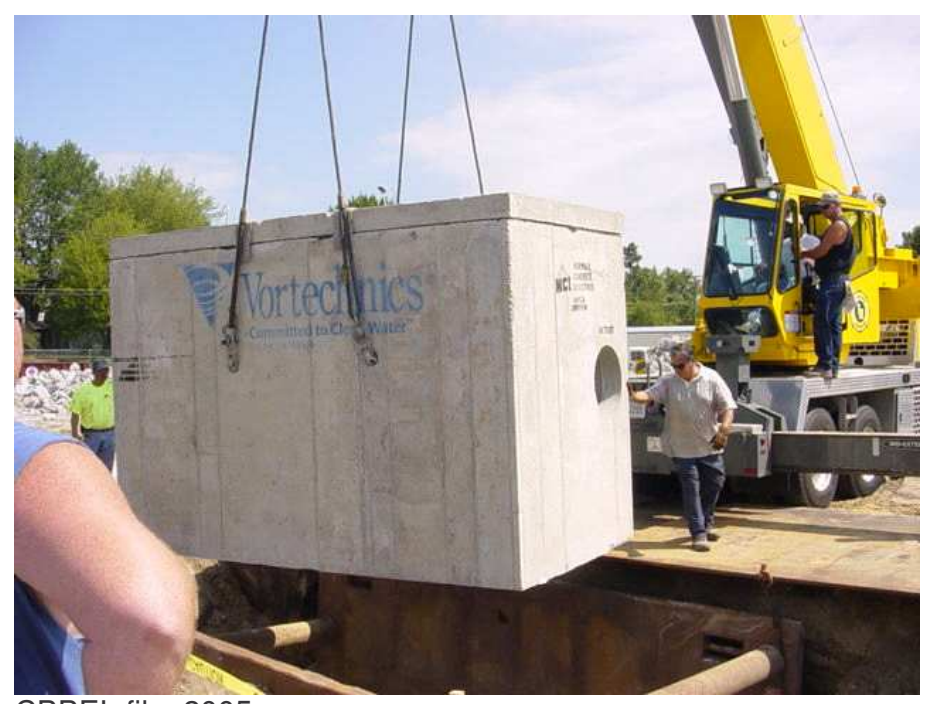

CBBEL file, 2005 


\section{Hydrodynamic Separators}

\section{Description:}

Installation of hydrodynamic separators can be grouped into in-line or off-line installations. Inline installations are typically only found on piped stormwater conveyance systems. Offline systems can be installed on closed stormwater systems or on open channels. Offline systems are often used to treat much larger flow rates than in-line systems. The flow to be treated is usually diverted to the stormwater treatment unit from the main conveyance system flow and then rejoins the main flow path once it is treated.

Hydrodynamic separators can be useful where space is limited or in areas susceptible to spills of petroleum products, such as gas stations. There are many manufacturers of hydrodynamic separators. The sizing and analysis methods used to demonstrate and verify the effectiveness of a unit varies widely among different manufacturers. The designer should establish a percent removal of a target particle size for the calculated water quality treatment rate. Figure 1 illustrates one of many different types of hydrodynamic separators.

\section{Drawings:}

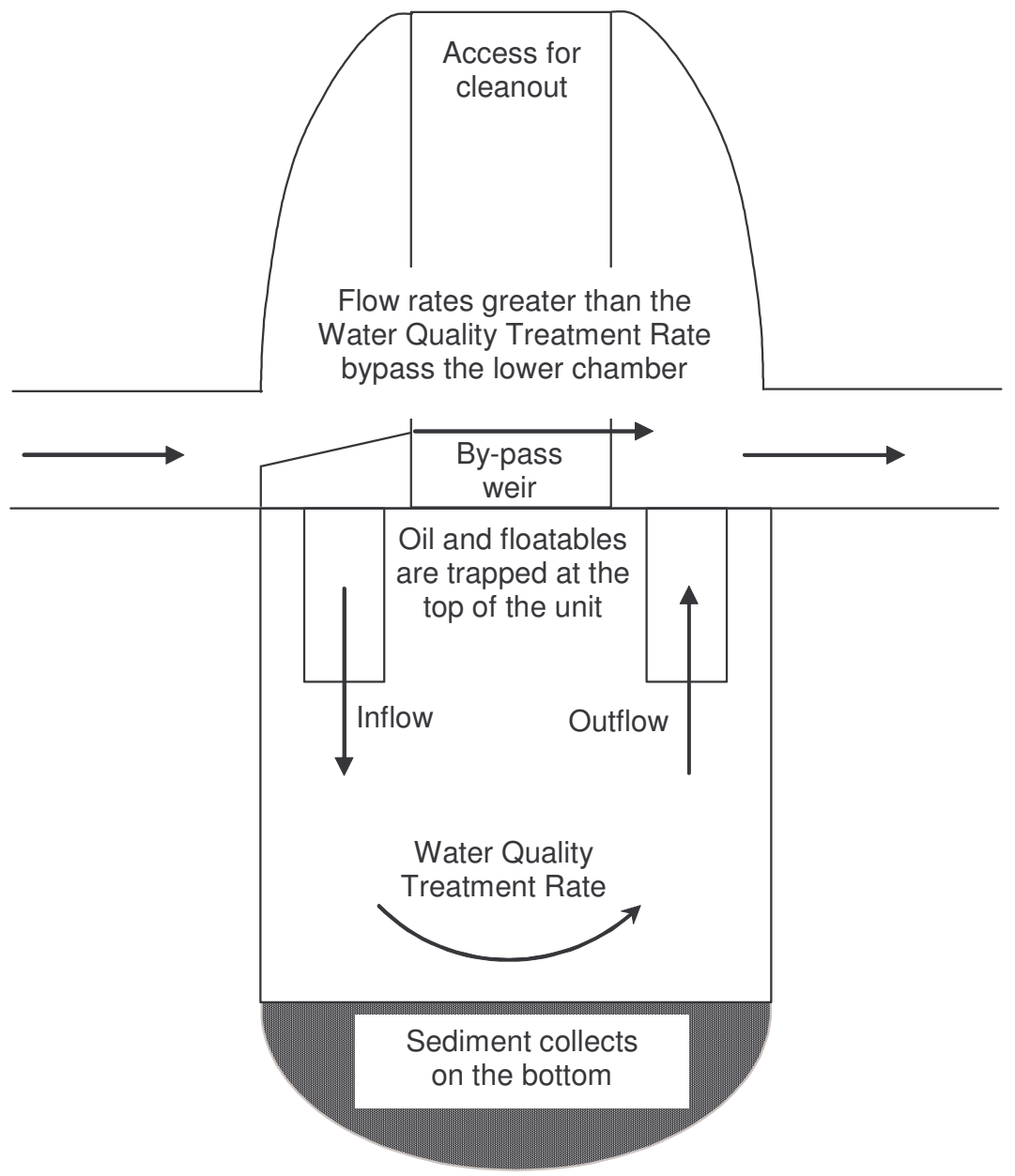

Figure 1: General Hydrodynamic

Separator Schematic (CBBEL, 2005)

\section{References:}

None 


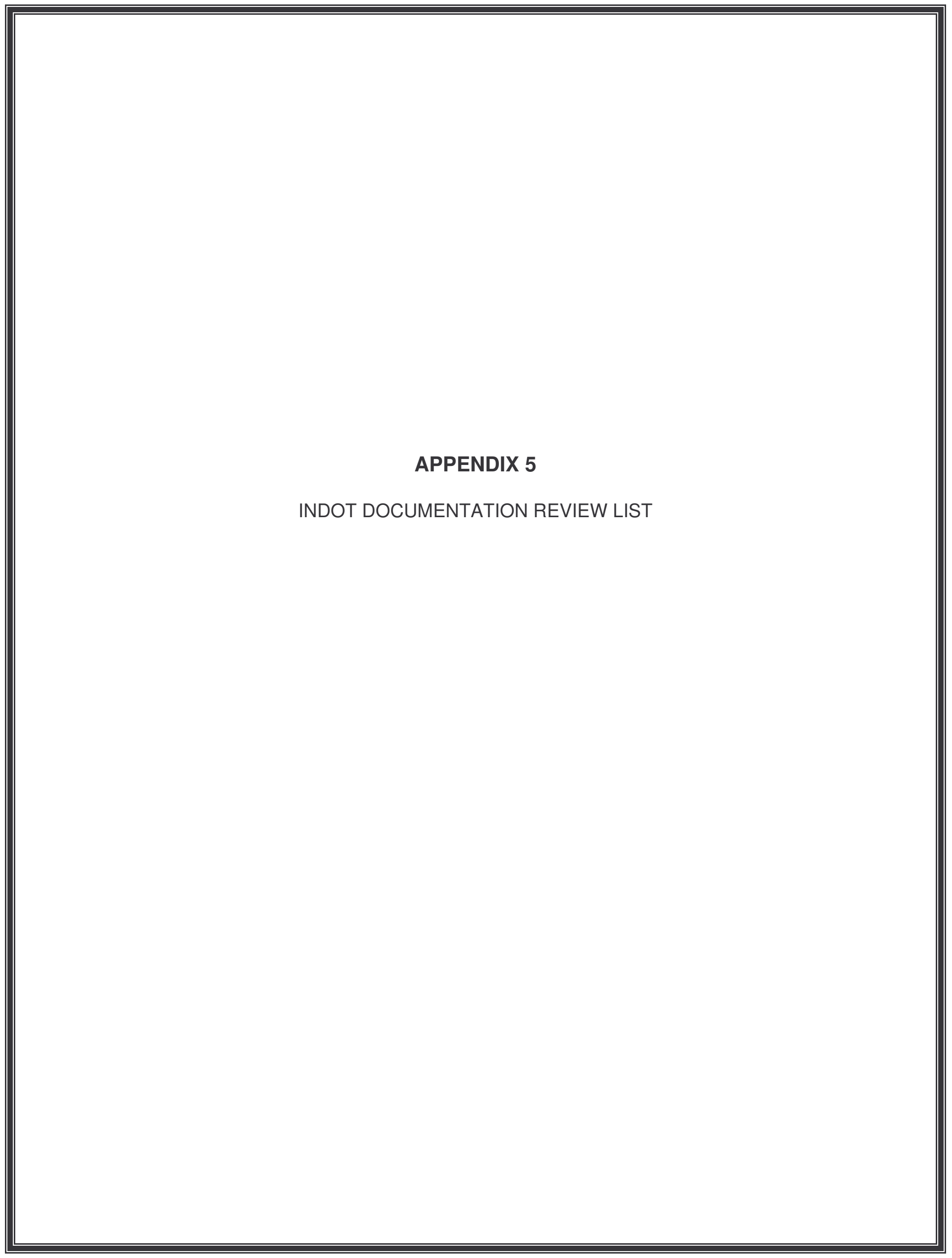


As a part of INDOT's Stormwater Quality Management Plan (SWQMP), a comprehensive review of INDOT documents has been performed. The objective of the review was to identify those document revisions that are recommended to be made to help satisfy requirements of the INDOT Storm Water Quality Management Plan (SWQMP).

Forty-five INDOT documents related the design, construction, and maintenance of INDOT roadways have been reviewed as a part of this study. Table 1 contains a list of all of the documents reviewed under the detailed study.

\section{Table 1: INDOT Documents Reviewed}

\begin{tabular}{|c|c|c|}
\hline Appraisal Manual & Design Manuals - Project Development & $\begin{array}{l}\text { Oversize/Overweight Vehicle Permitting } \\
\text { Handbook }\end{array}$ \\
\hline Aquifer Protection Guidelines & Design Manuals - Right-of-Way & Partnering Handbook \\
\hline Buyer's Manual & Design Manuals - Road Design & Pile Approval Form \\
\hline Certified Aggregate Technician Manual & Design Manuals - Structural Design & $\begin{array}{l}\text { Procedural Manual for Preparing } \\
\text { Environmental Studies }\end{array}$ \\
\hline $\begin{array}{l}\text { Certified Hot Mix Asphalt Technician } \\
\text { Program Manual }\end{array}$ & Design Manuals - Traffic Design & $\begin{array}{l}\text { Procedure and Special Provisions for } \\
\text { Soil Modification }\end{array}$ \\
\hline $\begin{array}{l}\text { Certified Technician Program Training } \\
\text { Manuals - Bridge Construction }\end{array}$ & $\begin{array}{l}\text { Design Manuals - Work Zone Traffic } \\
\text { Control }\end{array}$ & $\begin{array}{l}\text { Property Management Procedure } \\
\text { Manual }\end{array}$ \\
\hline $\begin{array}{l}\text { Certified Technician Program Training } \\
\text { Manuals - Concrete Paving }\end{array}$ & Design Memos & INDOT Recurring Special Provisions \\
\hline $\begin{array}{l}\text { Certified Technician Program Training } \\
\text { Manuals - Construction Procedures } 1\end{array}$ & Driveway Permit Manual & Relocation Program Manual \\
\hline $\begin{array}{l}\text { Certified Technician Program Training } \\
\text { Manuals - Construction Procedures } 2\end{array}$ & $\begin{array}{l}\text { Environmental Manual on Construction } \\
\text { Activity }\end{array}$ & $\begin{array}{l}\text { Requirements for Geotechnical } \\
\text { Investigation and Pavement } \\
\text { Investigation }\end{array}$ \\
\hline $\begin{array}{l}\text { Certified Technician Program Training } \\
\text { Manuals - Earthworks }\end{array}$ & Field Operations Manual & $\begin{array}{l}\text { Right-of-Way Acquisition Procedure } \\
\text { Manual for LPA's }\end{array}$ \\
\hline $\begin{array}{l}\text { Certified Technician Program Training } \\
\text { Manuals - Hot Mix Asphalt }\end{array}$ & $\begin{array}{l}\text { General Instructions for Bridge Structure } \\
\text { Investigation }\end{array}$ & Right-of-Way Engineering Manual \\
\hline Construction Memorandums & General Instructions to Field Employees & INDOT Standard Drawings \\
\hline Design Manuals - Hydrology/Hydraulics & Indiana Test Methods or Procedures & Standard Highway Signs \\
\hline Design Manuals - Location Surveys & $\begin{array}{l}\text { Manual on Uniform Traffic Control } \\
\text { Devices }\end{array}$ & INDOT Standard Specifications \\
\hline Design Manuals - Plan Development & Outdoor Advertising Control Manual & Transportation Enhancement Guide \\
\hline
\end{tabular}


APPENDIX 6

CONSTRUCTION ACTIVITY ENVIRONMENTAL MANUAL REVIEW 


\section{Introduction}

From INDOT's website, the Construction Activity Environmental Manual is described as "a reference for Project Engineers/Supervisors, geared to INDOT's construction personnel and contractors. It is intended to improve awareness about what environmental issues may be associated with different construction activities in Indiana. "

The Construction Activity Environmental Manual is divided into several main types of projects or project related concerns that include:

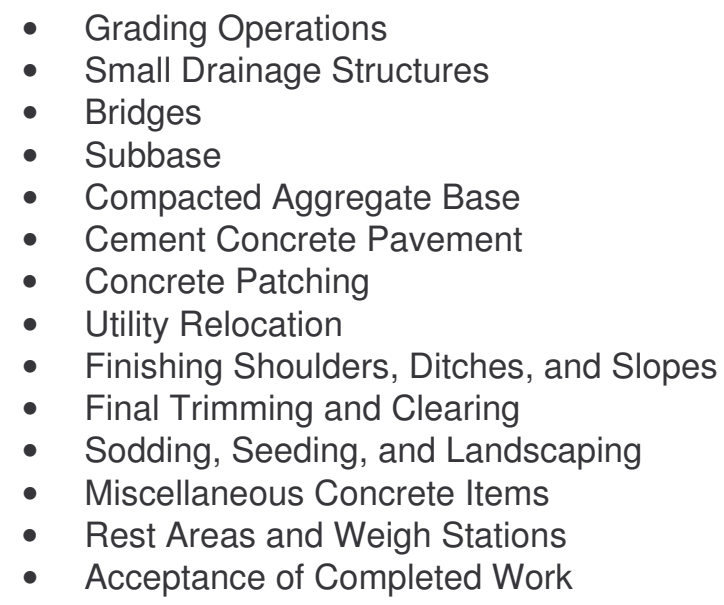

The document is organized such that within each of these sections pertinent environmental issues are addressed. In many cases this results in redundancy where the same material is repeated numerous times with limited variation in the content. Generally, there appear to be 33 primary information blocks that mainly focus on regulatory permitting and procedural requirements. These information blocks are listed in Table 1 below.

Table 1: Construction Activity Environmental Manual - Information Blocks

\begin{tabular}{|c|c|c|}
\hline \multicolumn{3}{|c|}{ Construction Activity - Environmental Manual (General Topics) } \\
\hline Archaeological /Historic Preservation & $\begin{array}{c}\text { COE Section 404/Section } 10 \text { Permits } \\
\text { (U.S.) }\end{array}$ & Asbestos \\
\hline Burning & $\begin{array}{l}\text { Coast Guard (U.S.) Bridge Permit and } \\
\text { Activity Letter }\end{array}$ & Concrete/Asphalt Batch Plants \\
\hline Construction in a Floodway & County/State Department Of Health & Dewatering Well Installation \\
\hline Ditch Reconstruction & Endangered Species & Fugitive Dust \\
\hline Hazardous Material & In Stream Blasting Permit & Injection Wells \\
\hline Karst & Lake Preservation Act (Permit) & Lead Paint \\
\hline Navigable Waterway Permit & NPDES Permit & Nuclear Regulatory Commission \\
\hline Open Burning & Rule 5 - Erosion Control & Section 401 Water Quality Certification \\
\hline Sole Source Aquifer & Solid Waste Disposal & Special Materials - Slag, Foundry Sand \\
\hline Spill Response & $\begin{array}{c}\text { Underground Storage Tanks/Leaking } \\
\text { Underground Storage Tanks }\end{array}$ & $\begin{array}{c}\text { Wastewater/Drinking Water Treatment } \\
\text { Plants }\end{array}$ \\
\hline Water Well Abandonment & Well Abandonment (Oil and Gas) & Wetlands \\
\hline
\end{tabular}




\section{Recommended Updates and Additional Information}

Eight of these information blocks should be updated to include requirements for construction phase erosion and sediment control and post-construction phase stormwater pollution prevention devices. Alternatively, a section could be added that summarizes how the current NPDES Phase II regulations (327 IAC 15-5 and 327 IAC 15-13) relate to INDOT procedures. For organization purposes, the eight potentially affected information blocks are discussed individually below.

\section{Ditch Reconstruction}

Regardless of whether an official Ditch Permit is needed from IDNR or if other regulatory permits or approvals are waived or not required, erosion and sediment control measures should be included in all ditch reconstruction projects regardless of size. This is due to water quality concerns.

\section{Fugitive Dust}

The fugitive dust is defined by "at least fifty percent $(50 \%)$ of the dust can be breathed in or is visible crossing the right-of-way." This number would be very difficult if not impossible to quantify in most situations. Dust emissions can become a particular nuisance in residential areas even when the dust release is not considered fugitive. Dust is a stormwater pollution concern especially when it is blown offsite where it readily washes off during rainfall. Spraying and chemical dust suppressants are identified as measures for dust control.

Soil roughening should also be mentioned as a dust control measure. Soil roughening increases the surface roughness and therefore decreases surface wind velocity and dust generation. Another worthy method of dust control is the maintenance of natural vegetation and wind barriers. If these barriers must be removed for the successful completion of the project, the construction sequencing should be such that the removal is performed as late in the construction process as reasonably possible.

\section{$\underline{\text { Hazardous Materials and Spill Response }}$}

Hazardous materials and spill response are covered under two separate sections in the Construction Activity Environmental Manual. Adequate information is provided in the manual describing the steps that should be taken if hazardous materials are spilled during the construction project. In the event of hazardous material discovery or a spill, the Contractor should prevent hazardous materials from entering waterways as much as possible. This information should also be included in the Stormwater Pollution Prevention Plan (SWPPP) for the project site.

Typically, the SWPPP is developed prior to the project letting by the Designer and will contain this information. However, if this information is not contained in the approved SWPPP, the Contactor is required to modify the SWPPP. On most projects, the Contractor will be amending the SWPPP in some way, shape, or form due to differing stormwater BMP, soil borrow areas or soil disposal areas, or changes in construction sequence. Therefore, the Contractor could simply include the appropriate sections of the Construction Activity Environmental Manual in the amended SWPPP submittal.

\section{$\underline{\text { In-Stream Blasting Permit }}$}

As the name implies, this type of permit is required from IDNR before setting or detonating explosives within Waters of the State. Erosion and sediment control measures, such as a turbidity curtain (silt boom) should be included for in-stream blasting. 


\section{$\underline{\text { Karst }}$}

The Construction Activity Environmental Manual identifies karst areas as direct connections to ground water aquifers. Where possible, the natural runoff rates to karst areas should not be modified regardless of whether or not the flow has been treated. Changes to the natural runoff rates may result in undue changes to the karst geology.

\section{Lake Preservation Act (Permit)}

This permit is essentially written approval to perform work at or lakeward of the legal shoreline. Similar to ditch reconstruction and in-stream blasting, erosion and sediment control measures, such as a turbidity curtain (silt boom) should be included for underwater blasting or any silt producing activity

\section{$\underline{\text { Rule } 5 \text { - Erosion Control }}$}

Rule 5 references should be added to the following sections:

- General Section - Add Rule 5 Permit description

- Grading over Peat Marshes

- Bridges Section - Introduction

- Cofferdams

- Falsework

- Subbase

- Compacted Aggregate Base

- Cement Concrete Pavement

- Utility Relocation

- Landscaping Operations

- Rest Areas and Weigh Stations

- Acceptance of Completed Work

The underlying purpose of adding the Rule 5 permit requirements to these sections is to reinforce the obligation of INDOT through their Contractors to meet the NPDES general permit requirements of 327 IAC 15-5.

Additional information discussed in the following sections should also be included. INDOT is responsible for submitting a Notice of Intent (NOI) to IDEM before land disturbing operations begin. Current regulations also now require that a Stormwater Pollution Prevention Plan (SWPPP) be developed for all new development and redevelopment that disturbs a total project area of 1 acre or greater. There are two primary elements of the SWPPP.

The first element covers construction phase erosion and sediment control measures. This will be the Contractor's main focus related to Rule 5 permitting requirements. The Contractor is responsible for the installation, inspection, modification, and regular maintenance of these measures. Additional measures must be added to prevent erosion and control sediment as site conditions warrant. The measures included in the approved SWPPP or design plans may not be sufficient to satisfy the erosion and sediment control requirements. The SWPPP is intended to be a minimum requirement for approximated site conditions. Two examples of scenarios where additional construction phase SWPPP (erosion and sediment control) measures should be added are:

1. During the design phase it was planned that the area of disturbance would be less than 0.4 ha $(1$ acre). A construction phase erosion and sediment control plan was developed, but not submitted to or approved by the SWPPP review authority (due to the anticipated acreage). During the construction phase, the Contractor utilizes some surrounding areas for material 
stockpile, equipment mobilization, and other construction activities. The additional area results in the total land disturbance being greater than 0.4 ha $(1 \mathrm{acre})$. As a result, an approved SWPPP is legally required for the project.

2. A construction project has an approved SWPPP. Following the first $1 / 2$ inch rainfall event, the Contractor discovers locations of off-site tributary area that were not anticipated. Although payment for the required measures would likely represent a change order for the contract, the Contractor is still required to amend the SWPPP to include the measures to address this unanticipated runoff.

Under Rule 5 requirements, the Contractor must also have a SWPPP for borrow or disposal areas that disturbed greater than 1 acre of land. Throughout the construction of the project, the Contractor should perform regular inspection of the erosion and sediment control measures. Inspections should be performed weekly or after a rainfall event accumulating more than $1 / 2$ inch in a 24 hour period. As mentioned in the INDOT Standard Specification Review Comments, an inspection log should be maintained by the Contractor.

Post-construction (permanent) stormwater pollution prevention devices are the second primary component of a SWPPP. Such devices should be designed and specified prior to contract letting. The Contractor's responsibility related to post-construction devices is to make sure construction is completed according to the project specifications or special provisions. The Contractor should also be aware that post-construction SWPPP elements should not be installed until upstream areas are stabilized.

\section{Acceptance of Completed Work}

Rule 5 requirements should be referenced for acceptance of completed work. In the INDOT Standard Specification Review Comments, it is recommended the Contractor shall provide INDOT information certifying that all conditions for the NPDES General Permit Rule 327 IAC 15-5 Notice of Termination (NOT) have been satisfied. The Department should then apply for the NOT once the information has been provided by the Contractor. It is further recommended that final acceptance and payment not be granted to the Contractor until IDEM has accepted the NOT. This is due to the fact that the NOT can be rejected and returned to the Owner (INDOT) due to site deficiencies.

\section{Conclusion}

The regulatory stormwater quality regulatory atmosphere has dramatically changed in the past decade. Accordingly, INDOT's obligations and the requirements they place on their Designers and Contractors will also change during the upcoming transition period. The information presented in the above discussion represents a significant change to the responsibility of the Contractor in the INDOT construction process. The Contractor will now be required to update the SWPPP and to provide information to INDOT as the project is finalized to attain the NOT and final payment. It is anticipated that some Contractor's may need assistance in this transition period. Because of this, it may be desirable for INDOT to develop a new independent Contractor's SWPPP Assistance Manual. This manual should:

- Identify situations requiring Contractor-initiated SWPPP changes

- Provide guidance on currently proposed changes to Details and Specifications

- Identify maintenance considerations

- Include SWPPP control measure inspection forms

- Contains a checklist for NOT information to be submitted by the Contractor to the Department to gain final acceptance and payment. 
APPENDIX 7

GENERAL INSTRUCTION TO FIELD EMPLOYEES REVIEW 


\begin{tabular}{|l|c|}
\hline Document & INDOT General Instructions to Field Employees \\
\hline Reference Section & Section 1 - Introduction \\
\hline Reference Part & Part 1 - Acronyms \\
\hline & Add the following acronyms to the current list: \\
& BFM - Bonded Fiber Matrix \\
BMP - Best Management Practice \\
MS4 - Municipal Separate Storm Sewer Systems \\
NOI - Notice of Intent \\
NOT - Notice of Termination \\
Revision & NPDS - National Pollutant Discharge Elimination System \\
& SWPPP - Stormwater Pollution Prevention Plan \\
TRM - Turf Reinforcement Mat \\
\hline Reason & Common abbreviations related to current stormwater pollution prevention and \\
\hline
\end{tabular}

\begin{tabular}{|c|c|}
\hline Document & INDOT General Instructions to Field Employees \\
\hline Reference Section & Section 1 - Introduction \\
\hline Reference Part & Part 7 - Utility Relocation Process - Construction Phase \\
\hline $\begin{array}{l}\text { Proposed } \\
\text { Revision }\end{array}$ & $\begin{array}{l}\text { - Add the following information as points } 4 \text { and } 5 \text {. Renumber the subsequent items. } \\
\text { 4. If the total land disturbance of the project is anticipated to be greater than } \\
1 \text { acre, verify that an approved SWPPP exists for the utility relocation } \\
\text { work. Verify the NOI for Rule } 5 \text { permitting requirements has been } \\
\text { submitted. Amend the approved SWPPP or develop an additional } \\
\text { SWPPP for the work as necessary. } \\
\text { 5. Install erosion and sediment control measures prior to initiating land } \\
\text { disturbance activities. }\end{array}$ \\
\hline Reason & $\begin{array}{l}\text { - Work performed for utility relocations also requires a SWPPP and Rule } 5 \text { permitting } \\
\text { approval if the total disturbed area of the project will be greater than } 1 \text { acre. } \\
\text { Erosion control measures should be installed regardless of the project size. }\end{array}$ \\
\hline
\end{tabular}




\begin{tabular}{|c|c|}
\hline Document & INDOT General Instructions to Field Employees \\
\hline Reference Section & Section 2 - General Instructions \\
\hline Reference Part & Part 3 - Initial Duties of the District \\
\hline $\begin{array}{l}\text { Proposed } \\
\text { Revision }\end{array}$ & $\begin{array}{l}\text { - Modify the last sentence of the fifth paragraph to read: } \\
\text { On contracts which involve Rule } 5 \text { Erosion and Sediment Control Compliance } \\
\text { (327-IAC } 15-5 \text { or } 327 \text { IAC 15-13) the Erosion and Sediment Control / } \\
\text { Stormwater Pollution Prevention Review Authority must be invited. Depending } \\
\text { on the project location, IDNR Division of Soil Conservation and / or the local } \\
\text { municipality may be the Review Authority. } \\
\text { - Modify the last sentence of the eighth paragraph to read: } \\
\text { For projects subject to Rule } 5 \text { permitting requirement, the Contractor needs to } \\
\text { advise the appropriate Permitting Authority in writing of changes to the } \\
\text { approved SWPPP. Changes to be reported include modification to the } \\
\text { approved construction sequence, including actual start and completion dates, } \\
\text { for each land disturbing activity and variations of the construction phase } \\
\text { erosion and sediment control measures from those described in the approved } \\
\text { SWPPP. The Contractor will be required to amend the SWPPP or develop a } \\
\text { separate SWPPP for borrow and disposal areas not permitted under the } \\
\text { approved SWPPP. } \\
\text { Modify point } 17 \text { under the General Checklist for Pre-Construction Conferences to } \\
\text { state: } \\
\text { 17. Erosion and Sediment Control requirements, including SWPPP } \\
\text { amendment procedures, erosion and sediment control measure } \\
\text { inspection and maintenance, and documentation of site conditions related } \\
\text { to erosion and sediment control devices }\end{array}$ \\
\hline Reason & $\begin{array}{l}\text { - It is the Contractor's responsibility to adhere to the approved SWPPP, amend the } \\
\text { SWPPP, or develop a separate SWPPPs where land disturbance activities are } \\
\text { greater than } 1 \text { acre. }\end{array}$ \\
\hline
\end{tabular}

\begin{tabular}{|l|c|}
\hline Document & INDOT General Instructions to Field Employees \\
\hline Reference Section & Section 2 - General Instructions \\
\hline Reference Part & Part 4 - Initial Duties of PE/S \\
\hline $\begin{array}{l}\text { Proposed } \\
\text { Revision }\end{array}$ & $\begin{array}{c}\text { Add the following items as potential special environmental requirements listed } \\
\text { under point (i): } \\
\text { Department of Environmental Management permits } \\
\text { Rule 5 NOI and SWPPP }\end{array}$ \\
\hline Reason & \begin{tabular}{c} 
Applicable environmental requirements. \\
\hline
\end{tabular} \\
\hline
\end{tabular}




\begin{tabular}{|l|l|}
\hline Document & INDOT General Instructions to Field Employees \\
\hline Reference Section & Section 3 - Grading \\
\hline Reference Part & Part 1 - General \\
\hline of the paragraph, to state: & $\begin{array}{l}\text { Modify the first paragraph, starting at the third sentence and going through the end } \\
\text { Psoposed }\end{array}$ \\
Revision & $\begin{array}{l}\text { amend Department's SWPPP was prepared to meet requirements of Rule } 5 \text { for } \\
\text { disturbance operations that are not permitted under the previously approved } \\
\text { SWPPP. An addendum shall be submitted to the appropriate Soil and Water } \\
\text { Conservation District and/or the Review Authority that received the } \\
\text { Department's original SWPPP for review. This submittal shall be made and } \\
\text { approved prior to the start of the affected grading operations. This information } \\
\text { shall also be provided to the PE/S. The Contractor is also required to obtain } \\
\text { any other necessary permits. }\end{array}$ \\
\hline Reason & $\begin{array}{l}\text { Applicable environmental requirements. This wording better defines the SWPPP } \\
\text { requirements of the Contractors and the associated process. }\end{array}$ \\
\hline
\end{tabular}

\begin{tabular}{|c|c|}
\hline Document & INDOT General Instructions to Field Employees \\
\hline Reference Section & Section 4 - Small Drainage Structures \\
\hline Reference Part & Part 1 - General \\
\hline $\begin{array}{l}\text { Proposed } \\
\text { Revision }\end{array}$ & $\begin{array}{l}\text { - Add the following paragraph: } \\
\text { As the Department's SWPPP was prepared to meet requirements of Rule } 5 \text { for } \\
\text { compliance with } 327 \text { IAC 15-5, the Contractor shall be required to either } \\
\text { amend the existing or develop a separate SWPPP to cover any land } \\
\text { disturbance operations that are not permitted under the previously approved } \\
\text { SWPPP. An addendum shall be submitted to the appropriate Soil and Water } \\
\text { Conservation District and/or the Review Authority that received the } \\
\text { Department's original SWPPP for review. This submittal shall be made and } \\
\text { approved prior to the start of the affected grading operations. This information } \\
\text { shall also be provided to the PE/S. The Contractor is also required to obtain } \\
\text { any other necessary permits. }\end{array}$ \\
\hline Reason & $\begin{array}{l}\text { - This paragraph is copied from the proposed revision for Section 3. Grading point } 1 . \\
\text { General. This information should also appear in the general information section of } \\
\text { Section 4. Small Drainage Structures. }\end{array}$ \\
\hline
\end{tabular}




\begin{tabular}{|l|l|}
\hline Document & INDOT General Instructions to Field Employees \\
\hline Reference Section & Section 5 - Bridges \\
\hline Reference Part & Part 1 - Introduction \\
\hline & $\begin{array}{c}\text { Add the following paragraph: } \\
\text { As the Department's SWPPP was prepared to meet requirements of Rule 5 for } \\
\text { compliance with } 327 \text { IAC 15-5, the Contractor shall be required to either } \\
\text { amend the existing or develop a separate SWPPP to cover any land } \\
\text { disturbance operations that are not permitted under the previously approved } \\
\text { Proposed } \\
\text { Revision } \\
\text { Conservation District and/or the Review Authority that received the } \\
\text { Department's original SWPPP for review. This submittal shall be made and } \\
\text { approved prior to the start of the affected grading operations. This information } \\
\text { shall also be provided to the PE/S. The Contractor is also required to obtain } \\
\text { any other necessary permits. }\end{array}$ \\
\hline Reason & $\begin{array}{l}\text { This paragraph is copied from the proposed revision for Section 3. Grading point 1. } \\
\text { General. This information should also appear in the introduction of Section 5. } \\
\text { Bridges. SWPPP requirements are applicable to all components of project } \\
\text { disturbing greater than 1 acre. }\end{array}$ \\
\hline
\end{tabular}

\begin{tabular}{|l|c|}
\hline Document & INDOT General Instructions to Field Employees \\
\hline Reference Section & Section 20-Sodding, Seeding and Landscaping \\
\hline Reference Part & General Comment \\
\hline $\begin{array}{l}\text { Proposed } \\
\text { Revision }\end{array}$ & $\begin{array}{l}\text { General Comment } \\
\text { Reason }\end{array}$ \\
$\begin{array}{l}\text { It is recommended that native Indiana species be used where possible. In the } \\
\text { event the Contractor wishes to substitute during seeding, sodding, or landscaping, } \\
\text { the INDOT field representative should be aware of acceptable native species for } \\
\text { substitution. The potential development of a new document titled INDOT } \\
\text { Vegetation Establishment Manual with Indiana Native Species is discussed in the } \\
\text { Future Document Needs section of this study. }\end{array}$ \\
\hline
\end{tabular}

\begin{tabular}{|l|l|}
\hline Document & INDOT General Instructions to Field Employees \\
\hline Reference Section & Section 27 - Notice of Completed Work \\
\hline Reference Part & Part 4. Final Acceptance \\
\hline $\begin{array}{l}\text { Proposed } \\
\text { Revision }\end{array}$ & $\begin{array}{c}\text { Add the following paragraph: } \\
\text { For projects that required a Rule } 5 \text { permit (327 IAC 15-5), the Contractor shall } \\
\text { provide the Department information certifying that all conditions for the NPDES } \\
\text { General Permit Rule (327 IAC 15-5) NOT have been satisfied. The } \\
\text { Department will apply for the NOT once the information has been provided by } \\
\text { the Contractor. The NOT shall be accepted by IDEM prior to final inspection, } \\
\text { acceptance, or payment. }\end{array}$ \\
\hline Reason & $\begin{array}{l}\text { Near the end of a typical INDOT construction project if subject to Rule } 5 \text { requirements, } \\
\text { the Contractor is to provide information needed to file the NOT. This will primarily } \\
\text { include a certification from the Contractor stating that all land disturbing activities have } \\
\text { been stabilized, no future land disturbing activities are planned for the project site, and } \\
\text { all temporary erosion and sediment control measures have been removed. At this } \\
\text { point, INDOT must submit the NOT to the local Soil and Water Conservation District or } \\
\text { other the previously designated NOI review entity. The request for termination is then } \\
\text { reviewed for concurrence and either returned to the OWNER or sent to IDEM for } \\
\text { acceptance. Because the NOT can be returned to the OWNER due to site deficiencies, } \\
\text { it is recommended that INDOT consider withholding final payment until the NOT is } \\
\text { accepted by IDEM. }\end{array}$ \\
\hline
\end{tabular}




\begin{tabular}{|l|l|}
\hline Document & INDOT General Instructions to Field Employees \\
\hline Reference Section & Section 40 - Construction Forms and Reports \\
\hline Reference Part & BMP Inspection Form (New Weekly Form) \\
\hline $\begin{array}{l}\text { Proposed } \\
\text { Revision }\end{array}$ & $\begin{array}{l}\text { A new standard form should be created for the documentation of BMP inspection. } \\
\text { Construction phase temporary erosion and sediment control BMPs should be } \\
\text { inspected by the Contractor at a minimum once every } 7 \text { days and after rain } \\
\text { activities totaling } 1 / 2 \text { inches of rainfall in a } 24 \text { hour period. The Contractor shall } \\
\text { keep daily records of a rain gauge installed in an unobstructed area on the project } \\
\text { site for measuring daily rainfall accumulation. The daily rainfall totals should be } \\
\text { recorded in the project documentation. BMPs that are found to be insufficient or in } \\
\text { need of repair should be upgraded or repaired within two days of the inspection. }\end{array}$ \\
\hline Reason & $\begin{array}{l}\text { As mentioned above, the BMP inspection should not only be performed on a } \\
\text { weekly basis, but after a 1/2 daily inch rainfall; therefore, a separate "rainfall event" } \\
\text { BMP inspection form may also need to be developed. }\end{array}$ \\
\hline
\end{tabular}

\begin{tabular}{|l|l|}
\hline Document & INDOT General Instructions to Field Employees \\
\hline Reference Section & Section 54 - Inspection and Maintenance of Stormwater BMPs (NEW SECTION) \\
\hline Reference Part & NEW SECTION \\
\hline $\begin{array}{l}\text { Proposed } \\
\text { Revision }\end{array}$ & $\begin{array}{l}\text { Proposed New Section. } \\
\text { Both construction phase BMPs for erosion and sediment control and post- } \\
\text { construction phase BMPs for long-term stormwater pollution prevention should be } \\
\text { inspected on a routine basis once their installation is completed. Although it is the } \\
\text { responsibility of the Contractor to inspect, document, and maintain the functionality } \\
\text { of these BMPs, the INDOT field personnel should also be qualified to inspect these } \\
\text { measures, answer questions the Contractor may have, and ensure proper } \\
\text { maintenance is performed. }\end{array}$ \\
\hline Reason & $\begin{array}{l}\text { The BMP Inspection form discussed in Section 40 can also be used by the INDOT } \\
\text { Construction Inspector to add to the construction record. An Erosion and Sediment } \\
\text { Control Inspector Certification Program would complement this GIFE requirement. } \\
\text { The potential development of a new document titled Erosion and Sediment Control } \\
\text { Inspection Certification Program is discussed in the Future Document Needs } \\
\text { section of this study. }\end{array}$ \\
\hline
\end{tabular}


APPENDIX 8

PROCEDURAL MANUAL FOR ENVIRONMENTAL STUDIES AND REVIEW 


\section{Introduction}

From INDOT's website, the application, purpose, and objective of the Procedural Manual for Preparing Environmental Studies is summarized as:

"This manual applies to all transportation projects developed by the Indiana Department of Transportation (INDOT) and to all local agency highway or local streets and roads projects with funding or approvals by the Federal Highway Administration (FHWA).

The purpose of the "Procedural Manual for Preparing Environmental Studies, August 2003" is to provide assistance with compliance of the National Environmental Policy Act (NEPA) and related federal laws, executive orders, regulations, and policies. The manual is intended for those preparing, reviewing, or sponsoring federally funded highway and related projects.

The objective of the manual is to focus on statutory and regulatory requirements for environmental documents for both local and INDOT projects. The manual sets forth document content and format, as required by law or regulation, and recommended format, if not specified by law or regulation. Reports and documents prepared for projects on the state highway system shall adhere to the content and recommended formats contained herein. In addition, the manual provides a number of tools for the development of the documentation including links to additional information."

The Procedural Manual for Preparing Environmental Studies does not have a numbered table of contents and is divided into categories that discuss pertinent environmental considerations.

There is one recommended addition that should be made to this document. Rule 5 permitting considerations should be added to the list of environmental permits. Currently Section 401 Water Quality Act (COE), Section 404 Water Quality Certification (IDEM), and Construction in a Floodway Permit (IDNR) are the only permits currently listed. 
APPENDIX 9

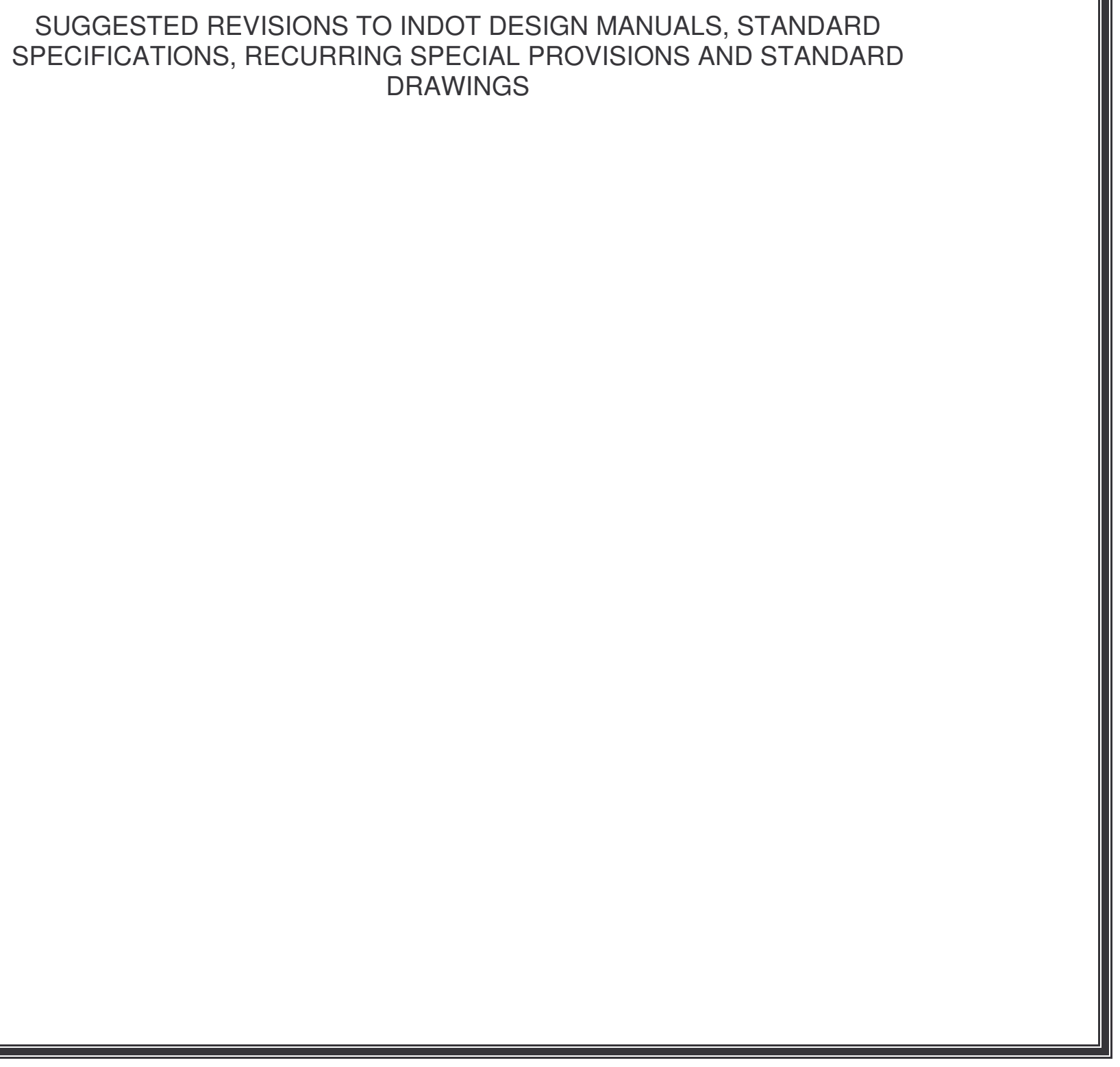




\title{
December 2005
}

\section{Comments and Suggested Revisions}

\author{
INDOT Design Manuals \\ INDOT Standard Specifications \\ INDOT Standard Drawings \\ INDOT Recurring Special Provisions
}




\section{Construction Phase BMP Recommendations}




\section{General:}

This Section is one part of a comprehensive review of INDOT documentation related to INDOT's Storm Water Quality Master Plan (SWQMP). The comments in this Section are related to Construction Phase Best Management Practices (BMPs).

\section{Documents Covered:}

- INDOT Design Manuals

- INDOT Standard Specifications

- INDOT Recurring Special Provisions

- INDOT Standard Drawings

\section{Organization:}

Specific recommended revisions and additions to the above listed documents are summarized by BMP as they pertain to individual measures. Some of the recommended BMPs do not require specific revisions to INDOT documents for inclusion within INDOT projects. BMPs that are recommend for use in constructing, retrofitting, and maintaining INDOT roadways and facilities are listed in Table 1.

\section{Table 1: Construction Phase BMPs}

\begin{tabular}{|l|}
\hline \multicolumn{1}{|c|}{ Construction Phase BMPs } \\
\hline Bonded Fiber Matrix (BFM Mulch) \\
\hline Erosion Control Blanket \\
\hline Fiber Wattle Roll Ditch Check \\
\hline Grading \\
\hline Inlet Protection (Perimeter Barrier) \\
\hline Temporary Seeding \\
\hline Rock Check Dams \\
\hline Sediment Basin \\
\hline Sediment Trap \\
\hline Sequencing \\
\hline Silt Fences \\
\hline Soil Roughening \\
\hline Straw Bale Ditch Check \\
\hline Straw Mulch \\
\hline Structural Methods \\
\hline Surface Water Diversion \\
\hline Turbidity Curtain \\
\hline Vehicle Tracking Pads \\
\hline
\end{tabular}




\section{Construction Phase BMP Component - Bonded Fiber Matrix (BFM) Mulch}

\section{PART I - INDOT Design Manuals}

\begin{tabular}{|c|c|}
\hline Document & INDOT Design Manual \\
\hline Reference Chapter & Chapter 37 - Temporary Erosion and Sediment Control \\
\hline Reference Section & 37-3.02(03) Temporary Seeding and Temporary Mulching \\
\hline Proposed Revision & $\begin{array}{l}\text { - Add the following sentence as the fourth sentence of the first paragraph: } \\
\text { Bonded Fiber Matrix (BFM) is similar to mulching except its use should be considered } \\
\text { for areas of steep or sensitive slopes. } \\
\text { - Modify the beginning of the last paragraph to read "When mulch or BFM." }\end{array}$ \\
\hline
\end{tabular}

\section{PART II - INDOT Standard Specifications}

\begin{tabular}{|l|l|}
\hline Document & INDOT Standard Specifications \\
\hline Reference Location & SECTION 200 - EARTHWORK \\
\hline Reference Location & SECTION 205 - TEMPORARY EROSION AND SEDIMENT CONTROL \\
\hline Reference Location & 205.03 Control Measures \\
\hline & $\begin{array}{l}\text { Add the following as new section 205.03(p) Bonded Fiber Matrix (BFM): } \\
\text { (p) Bonded Fiber Matrix (BFM). The BFM should be continuous layer of } \\
\text { elongated fiber strands held together by a high-grade water-resistant tackifier } \\
\text { bonding agent. BFM should be installed so that it adheres directly to the } \\
\text { exposed surface and allows no gaps between the product and the soil. It } \\
\text { should not form a water-insensitive crust that can inhibit plant growth. The } \\
\text { BFM should biodegrade completely into materials known to be beneficial to } \\
\text { plant growth. The BFM should not be installed immediately before, during, or } \\
\text { after rainfall and shall have a 24-hour precipitation clear period after } \\
\text { installation to allow the material to dry. }\end{array}$ \\
& $\begin{array}{l}\text { The manufacturer's recommendations shall be followed with regard to } \\
\text { shipping, handling, storage, protection, mixing, and installation of the product. } \\
\text { Manufacturer's certifications and material samples shall be provided prior to } \\
\text { installation. }\end{array}$ \\
\hline
\end{tabular}

\begin{tabular}{|l|c|}
\hline Document & INDOT Standard Specifications \\
\hline Reference Location & SECTION 200 - EARTHWORK \\
\hline Reference Location & SECTION 205 - TEMPORARY EROSION AND SEDIMENT CONTROL \\
\hline Reference Location & \begin{tabular}{c} 
205.06 Method of Measurement \\
\hline Proposed Revision
\end{tabular} \\
$\begin{array}{c}\text { Modify this section and the method of measurement information:. } \\
\text { Bonded fiber matrix (BFM) will be measured by the square meter (square } \\
\text { yard) or hectare (acre) }\end{array}$ \\
\hline
\end{tabular}




\begin{tabular}{|c|c|}
\hline Document & INDOT Standard Specifications \\
\hline Reference Location & SECTION 200 - EARTHWORK \\
\hline Reference Location & SECTION 205 - TEMPORARY EROSION AND SEDIMENT CONTROL \\
\hline Reference Location & 205.07 Basis of Payment \\
\hline Proposed Revision & 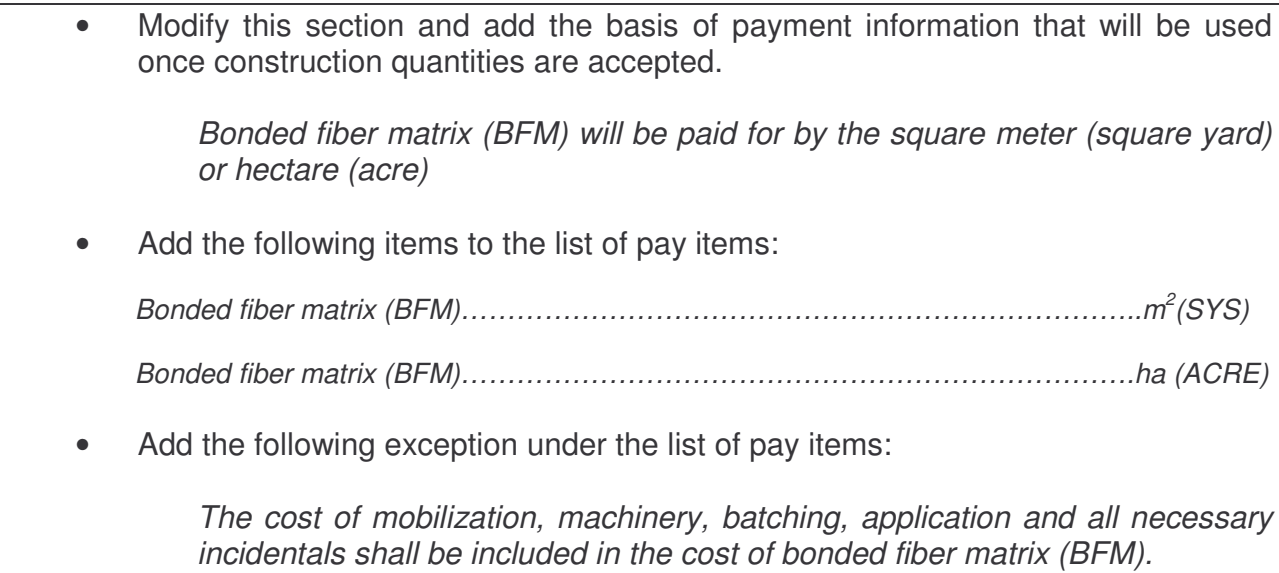 \\
\hline
\end{tabular}

\begin{tabular}{|c|c|}
\hline Document & INDOT Standard Specifications \\
\hline Reference Location & SECTION 600 - INCIDENTAL CONSTRUCTION \\
\hline Reference Location & SECTION 621 - SEEDING AND SODDING \\
\hline Reference Location & 621.05 Applying Fertilizer, Seed, and Mulch \\
\hline Proposed Revision & $\begin{array}{l}\text { - Add the follow mulching method: } \\
\text { 6. Method } \boldsymbol{F} \text {. The area may be covered in bonded fiber matrix (BFM). This } \\
\text { method shall be limited to areas that are excessively steep or are } \\
\text { inaccessible for conventional mulching or erosion control blanket installation. } \\
\text { See Section } 205 \text {. }\end{array}$ \\
\hline
\end{tabular}




\begin{tabular}{|c|c|}
\hline Document & INDOT Standard Specifications \\
\hline Reference Location & SECTION 900 - MATERIALS DETAILS \\
\hline Reference Location & SECTION 914 - ROADSIDE DEVELOPMENT MATERIALS \\
\hline Reference Location & 914.05 Mulch \\
\hline Proposed Revision & $\begin{array}{l}\text { - Add the following new section } 914.05(a)(6) \text { Bonded Fiber Matrix: } \\
\text { 6. Bonded Fiber Matrix (BFM) BFM materials shall be made from virgin } \\
\text { wood chips blended uniformly with approximately with } 10 \% \text { non-toxic tackifier } \\
\text { to form a strong bond with the fiber matrix. The wood chips should be } \\
\text { thermally processed to ensure no reduction in seed germination or growth } \\
\text { rates. Fertiilizer may be added. Any pigmentation used shall be organic and } \\
\text { non-toxic. The pH of the applied product shall not cause negative effects on } \\
\text { the vegetation or environment. } \\
\text { The matrix should be hydraulically applied and limited to areas that are too } \\
\text { steep or inaccessible for conventional stabilization methods. Minimum } \\
\text { application rates should be } 4,480 \text { kg/ha (4,000 lbs/acre) for } 1: 1 \text { slopes, } 3920 \\
\text { kg/ha (3,500 lbs/acre) for slopes between } 1: 1 \text { and } 2: 1 \text {, and } 3,360 \mathrm{~kg} / \mathrm{ha} \\
\text { (3,000 lbs/acre) for } 3: 1 \text { slopes or flatter. Follow manufacturers batching and } \\
\text { installation guidelines. } \\
\text { Materials shall remain in factory labeled packages until installation and shall } \\
\text { be stored to protect from weather or heat damage. } \\
\text { Water content shall be limited to } 15 \% \text { maximum. Limit ash content to } 1 \% \\
\text { maximum. The overall organic content of the system shall be } 98 \% \text { or greater. } \\
\text { Do not apply BFM when rainfall is expected within } 24 \text { hours of installation. }\end{array}$ \\
\hline
\end{tabular}

\begin{tabular}{|l|c|}
\hline Document & INDOT Standard Specifications \\
\hline Reference Location & SECTION 200 - EARTHWORK \\
\hline Reference Location & SECTION 205 - TEMPORARY EROSION AND SEDIMENT CONTROL \\
\hline Reference Location & 205.02 Materials \\
\hline Proposed Revision & $\begin{array}{r}\text { Add the following items alphabetically to the list of materials. Add the appropriate } \\
\text { section reference number: }\end{array}$ \\
& Bonded Fiber Matrix (BFM) \\
\hline
\end{tabular}

\section{PART III - INDOT Standard Drawings}

No Recommended Revisions

\section{PART IV - INDOT Recurring Special Provisions}

No Recommended Revisions 


\section{Construction Phase BMP Component - Erosion Control Blanket}

\section{PART I - INDOT Design Manuals}

No Recommended Revisions

\section{PART II - INDOT Standard Specifications}

\begin{tabular}{|l|l|}
\hline Document & INDOT Standard Specifications \\
\hline Reference Location & SECTION 200 - EARTHWORK \\
\hline Reference Location & SECTION 205 - TEMPORARY EROSION AND SEDIMENT CONTROL \\
\hline Reference Location & 205.03 Control Measures \\
\hline & $\begin{array}{l}\text { Add the following as new section 205.03(s) Erosion Control Blankets: } \\
\text { Proposed Revision }\end{array}$ \\
$\begin{array}{l}\text { (s) Erosion Control Blankets. The manufacturer's recommendations shall } \\
\text { be followed with regard to shipping, handling, storage, installation, and } \\
\text { protection from direct sunlight. The blanket will be rejected if it has defects, } \\
\text { tears, punctures, flaws, deterioration, or damage incurred during } \\
\text { manufacture, transportation, storage, or installation. Each roll shall be labeled } \\
\text { or tagged to provide product identification. }\end{array}$ \\
$\begin{array}{l}\text { The original copies of all necessary current manufacturers' installation } \\
\text { manuals shall be provided prior to installation. The blanket shall be anchored } \\
\text { and seamed according to manufacturer's recommendations. The blanket } \\
\text { must be secured to the ground using staples or other approved method by } \\
\text { following the manufacturer's recommended staple pattern based on slope } \\
\text { and application. }\end{array}$ \\
\hline
\end{tabular}

\begin{tabular}{|c|c|}
\hline Document & INDOT Standard Specifications \\
\hline Reference Location & SECTION 200 - EARTHWORK \\
\hline Reference Location & SECTION 205 - TEMPORARY EROSION AND SEDIMENT CONTROL \\
\hline Reference Location & 205.07 Basis of Payment \\
\hline Proposed Revision & $\begin{array}{l}\text { - Modify this section and add the basis of payment information that will be used } \\
\text { once construction quantities are accepted. } \\
\text { Erosion control blankets will be paid for by the square meter (square yard) } \\
\text { - Add the following items to the list of pay items: } \\
\text { Erosion control blanket, type } \\
\text { Add the following exception under the list of pay items: } \\
\text { The cost for stapling, anchoring, overlap, and excess material required shall } \\
\text { be included in the cost of erosion control blanket. }\end{array}$ \\
\hline
\end{tabular}




\begin{tabular}{|c|c|}
\hline Document & INDOT Standard Specifications \\
\hline Reference Location & SECTION 900 - MATERIALS DETAILS \\
\hline Reference Location & SECTION 914 - ROADSIDE DEVELOPMENT MATERIALS \\
\hline Reference Location & 914.09 Miscellaneous Materials \\
\hline Proposed Revision & $\begin{array}{l}\text { - Add the following text to the end of section } 914.09(f) \text { Staples. } \\
\text { Staples should be installed in accordance with manufacturer's recommended } \\
\text { staples patterns. Staple locations should be clearly marked on the mat with } \\
\text { paint so the installation can be inspected. The minimum staple requirements } \\
\text { shall be met: } \\
\text { 4:1 Slopes }-0.85 \text { staples } / \mathrm{m}^{2}\left(0.7 \text { staples } / \mathrm{yd}^{2}\right) \\
\text { 3:1 Slopes }-1.40 \text { staples } / \mathrm{m}^{2}\left(1.15 \mathrm{staples} / \mathrm{yd}^{2}\right) \\
2: 1 \text { Slopes and Steeper }-2.0 \text { staples } / \mathrm{m}^{2}\left(1.7 \mathrm{staples} / \mathrm{yd} \mathrm{d}^{2}\right) \\
\text { Medium/High Flow Channels }-4.1 \mathrm{staples} / \mathrm{m}^{2}\left(3.4 \mathrm{staples} / \mathrm{yd} \mathrm{d}^{2}\right) \\
\text { High Flow Channel and Shoreline }-4.5 \mathrm{staples} / \mathrm{m}^{2}\left(3.75 \mathrm{staples} / \mathrm{yd} \mathrm{d}^{2}\right)\end{array}$ \\
\hline
\end{tabular}

\section{PART III - INDOT Standard Drawings}

\begin{tabular}{|c|c|}
\hline Document & INDOT Standard Drawings \\
\hline Reference Location & Section 200 - Earthwork \\
\hline Reference Drawing & E 205-TECS-04 (M 205-TECS-04) (Now Unassigned) (NEW DRAWING) \\
\hline Code Meaning & TECS - Temporary Erosion Control Slope \\
\hline Drawing Title & Rolled Erosion Control Product Installation (General) \\
\hline Proposed Revision & $\begin{array}{l}\text { - A new drawing should be created for rolled erosion control blanket installation for } \\
\text { slope installations. The drawing should contain information for blanket installation } \\
\text { on slopes, along drainage channels, and along shorelines. Seaming, anchoring, } \\
\text { and overlapping of the rolls should also be shown. General instructions for all } \\
\text { erosion control blanket installations are: } \\
\text { 1. Prepare the seedbed by raking, seeding and fertilizing. } \\
\text { 2. Use trenching and anchoring procedures to secure any exposed material ends. } \\
\text { 3. Keep material in direct contact with the ground. } \\
\text { 4. Blankets will unroll with appropriate side against soil surface. } \\
\text { 5. Use the required number of staples. } \\
\text { 6. Secure all material overlaps with the required number and spacing of staples. } \\
\text { Seams may also be mechanically sewn according to manufacturer } \\
\text { recommendations. } \\
\text { - In slope and channel applications, overlap material in the direction of water flow. } \\
\text { For slope installation applications: } \\
\text { 1. Prepare soil before installing blankets, including any necessary application of } \\
\text { lime, fertilizer, and seed. } \\
\text { 2. Anchor the blanket at the top of the slope in a 15-cm (6-inch) deep by } 15-\mathrm{cm}(6- \\
\text { inch) wide trench with a row of staples/stakes approximately } 30 \mathrm{~cm}(12 \text { inches) } \\
\text { apart in the bottom of the trench. Leave approximately } 30 \mathrm{~cm} \text { (12 inches) of } \\
\text { blanket extended beyond the up-slope portion of the trench. Backfill and compact } \\
\text { the trench after stapling and apply seed to compacted soil. Fold remaining } 30-\mathrm{cm}\end{array}$ \\
\hline
\end{tabular}




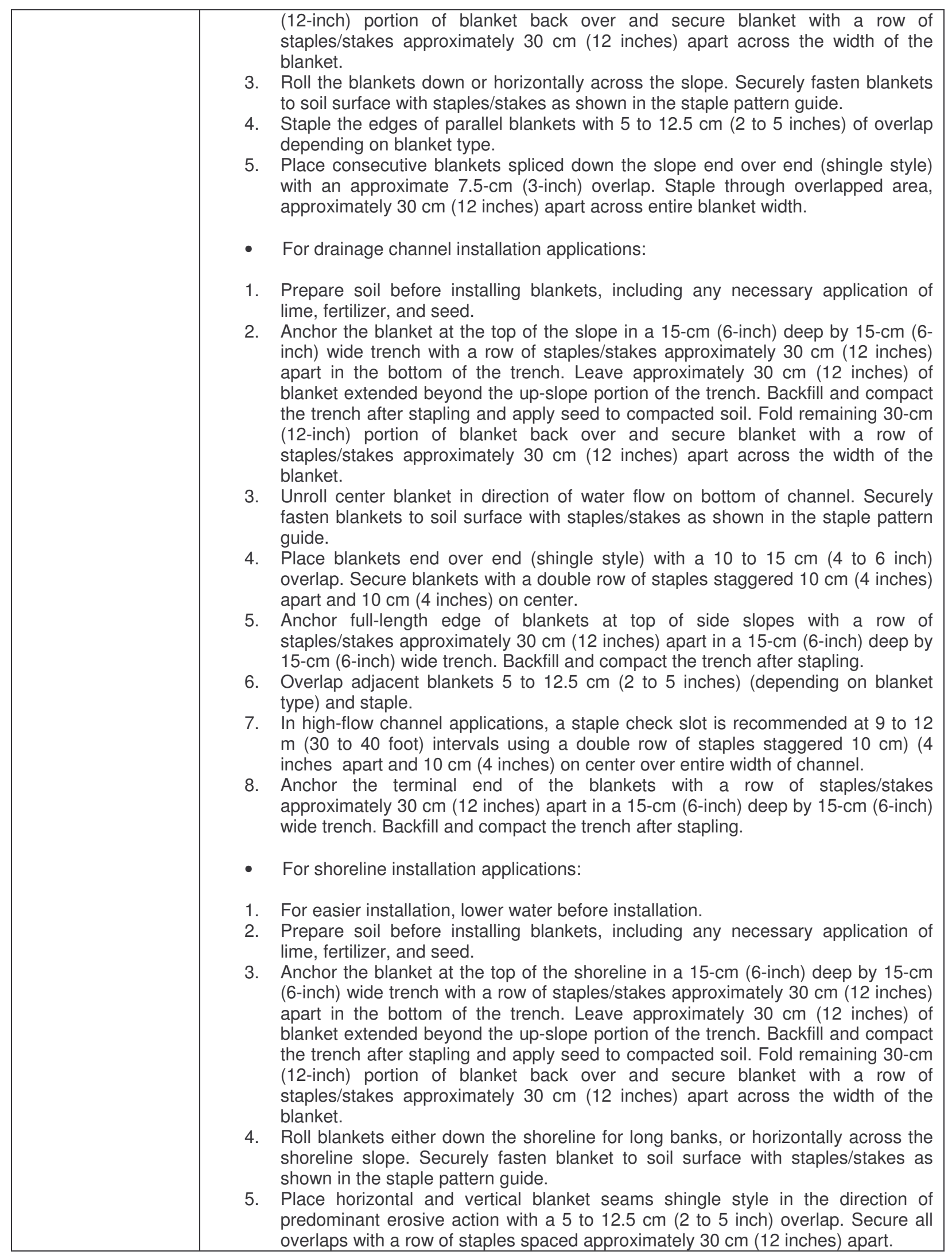




\begin{tabular}{|l|l|}
\hline 6. $\begin{array}{l}\text { Anchor the edge of the blanket at or below normal water level in a 30-cm (12-inch) } \\
\text { deep by 15-cm (6-inch) wide trench with a row of staples/stakes spaced } \\
\text { approximately } 30 \mathrm{~cm}(12 \text { inches) apart. Backfill and compact the trench after } \\
\text { stapling (stone or soil may be used as backfill). }\end{array}$ \\
$\begin{array}{l}\text { The following notes should be added for all installations: "For installation in loose } \\
\text { soil, the staple length requirements of } 914.09(f) \text { shall be increased to the length } \\
\text { required to secure the blanket." }\end{array}$ \\
$\begin{array}{l}\text { The following notes should be added for all installations along drainage channel } \\
\text { and shorelines: "For perennial streams with observable baseflow, the erosion } \\
\text { control blanket extent below the waterline shall be limited to that length which is } \\
\text { required for anchoring the mat." }\end{array}$
\end{tabular}

\begin{tabular}{|l|l|}
\hline Document & INDOT Standard Drawings \\
\hline Reference Location & $\begin{array}{l}\text { Section 200 - Earthwork } \\
\text { Reference Drawing }\end{array}$ \\
(NEW DRAWING)
\end{tabular}

\title{
PART IV - INDOT Recurring Special Provisions
}

\author{
No Recommended Revisions
}




\section{Construction Phase BMP Component - Fiber Wattle Roll Ditch Check}

\section{PART I - INDOT Design Manuals}

\begin{tabular}{|c|c|}
\hline Document & INDOT Design Manual \\
\hline Reference Chapter & Chapter 37 - Temporary Erosion and Sediment Control \\
\hline Reference Section & 37-3.03(01) Check Dams \\
\hline Proposed Revision & $\begin{array}{l}\text { - Add the following sentence to the end of the paragraph: } \\
\text { Within the construction clear zone, straw bales, fiber wattle rolls, or other approved } \\
\text { means, should be used instead of riprap. }\end{array}$ \\
\hline
\end{tabular}

\section{PART II - INDOT Standard Specifications}

\begin{tabular}{|c|c|}
\hline Document & INDOT Standard Specifications \\
\hline Reference Location & SECTION 200 - EARTHWORK \\
\hline Reference Location & SECTION 205 - TEMPORARY EROSION AND SEDIMENT CONTROL \\
\hline Reference Location & 205.03 Control Measures \\
\hline Proposed Revision & $\begin{array}{l}\text { - Modify 205.03(c) about check dams to state: } \\
\text { (c) Check Dams. Check dams shall at a minimum be constructed of } \\
\text { revetment riprap or fiber wattle rolls as shown on the Standard Drawings. } \\
\text { Additional check dam construction requirements may be shown on the plans. } \\
\text { - Add the following as section } 205.03(\mathrm{c})(3) \text { as fiber wattle roll ditch checks: } \\
\text { 3. Fiber Wattle Roll. Fiber wattle rolls shall be embedded and staked as } \\
\text { shown on the plans. At a minimum, the fiber wattle rolls must extend across } \\
\text { the full width of the swale or ditch. The bottom elevation of the end wattle } \\
\text { rolls shall be a minimum of } 6 \text { inches above the top elevation of the lowest } \\
\text { wattle role. The ditch checks shall be spaced at intervals such that the top of } \\
\text { the downstream check is at the same elevation as the toe invert of the } \\
\text { adjacent upstream check. Place wattle rolls such that gaps between adjacent } \\
\text { rolls are eliminated. }\end{array}$ \\
\hline
\end{tabular}

\begin{tabular}{|l|c|}
\hline Document & INDOT Standard Specifications \\
\hline Reference Location & SECTION 200 - EARTHWORK \\
\hline Reference Location & SECTION 205 - TEMPORARY EROSION AND SEDIMENT CONTROL \\
\hline Reference Location & \begin{tabular}{c}
205.06 Method of Measurement \\
\hline Proposed Revision
\end{tabular} \\
& $\begin{array}{c}\text { Modify this section and the method of measurement information: } \\
\text { Fiber wattle roll check dams will be measured by the meter (linear foot) }\end{array}$ \\
\hline
\end{tabular}




\begin{tabular}{|c|c|}
\hline Document & INDOT Standard Specifications \\
\hline Reference Location & SECTION 200 - EARTHWORK \\
\hline Reference Location & SECTION 205 - TEMPORARY EROSION AND SEDIMENT CONTROL \\
\hline Reference Location & 205.07 Basis of Payment \\
\hline Proposed Revision & 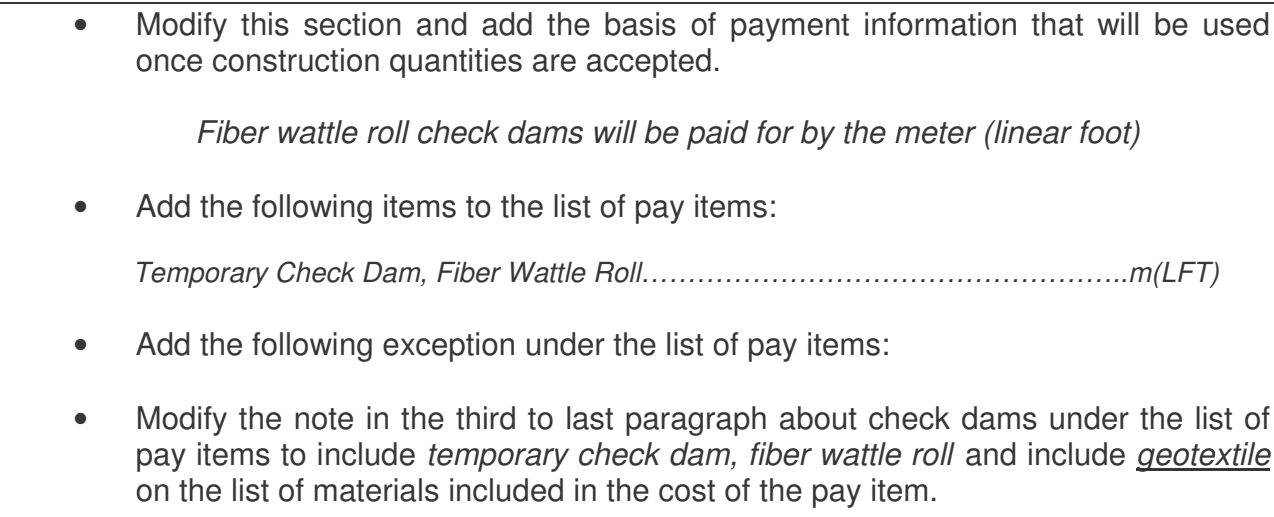 \\
\hline
\end{tabular}

\begin{tabular}{|l|c|}
\hline Document & INDOT Standard Specifications \\
\hline Reference Location & SECTION 200 - EARTHWORK \\
\hline Reference Location & SECTION 205 - TEMPORARY EROSION AND SEDIMENT CONTROL \\
\hline Reference Location & 205.02 Materials \\
\hline Proposed Revision & $\begin{array}{c}\text { Add the following items alphabetically to the list of materials. Add the appropriate } \\
\text { section reference number: }\end{array}$ \\
& Fiber Wattle Roll \\
& Geotextile Under Fiber Wattle Roll \\
\hline
\end{tabular}




\title{
PART III - INDOT Standard Drawings
}

\begin{tabular}{|c|c|}
\hline Document & INDOT Standard Drawings \\
\hline Reference Location & Section 200 - Earthwork \\
\hline Reference Drawing & E 205-TECD-03 (M 205-TECD-03) (Now Unassigned) (NEW DRAWING) \\
\hline Code Meaning & TECD - Temporary Erosion Control Ditch \\
\hline Drawing Title & Temporary Check Dam, Fiber Wattle Roll \\
\hline Proposed Revision & $\begin{array}{l}\text { A new drawing should be created for fiber wattle rolls used as temporary ditch } \\
\text { check dams. The drawing will be similar to the details for the straw bale } \\
\text { temporary check dam. This drawing should contain the following information } \\
\text { either as written text or shown on the drawing: } \\
\text { - Embed the wattle a minimum of } 4 \text { inches. } \\
\text { - The ends of adjacent wattles should be tightly abutted or overlapped } 6 \\
\text { inches so that no opening exists for water or sediment to pass through. } \\
\text { - Wooden stakes should be placed } 6 \text { inches from the wattle end and angled } \\
\text { towards the adjacent wattle. Space stakes } 4 \text { feet on center and drive flush } \\
\text { where soil conditions permit. } \\
\text { Wattles may not be stacked. The standard wattle size should be } 12 \text { inches } \\
\text { in diameter. The wattle should be placed such that the top of the } \\
\text { downstream wattle is at the elevation of the bottom of the next upstream } \\
\text { wattle. } \\
\text { Similar to straw bales, two rows of wattles should be used. Joints must be } \\
\text { staggered. } \\
\text { Wattle should be tied down as needed to offset the effects of buoyancy. } \\
\text { - Geotextile mat may be installed downstream of the mat for scour protection. } \\
\text { Install the geotextile beneath the wattles and extend it to the upstream side. } \\
\text { The size of the geotextile mat should vary depending on the width of the } \\
\text { swale or ditch. Alternatively, similar to the straw bale detail, a } 6 \text {-foot } 6 \text {-inch } \\
\text { by } 6 \text {-foot } 6 \text {-inch mat could be shown. Secure the mat downstream of the } \\
\text { wattles with staples or wooden stakes placed } 3 \text { feet on center. } \\
\text { - Add the following text as a general note: } \\
\text { Fiber wattle rolls must extend across the full width of the swale or ditch. } \\
\text { The bottom elevation of the end wattle shall be a minimum of } 6 \text { inches } \\
\text { above the top elevation of the wattle. The ditch checks shall be spaced at } \\
\text { intervals such that the top of the downstream check is at the same } \\
\text { elevation as the toe invert of the adjacent upstream check. }\end{array}$ \\
\hline
\end{tabular}

\section{PART IV - INDOT Recurring Special Provisions}

\author{
No Recommended Revisions
}




\section{Construction Phase BMP Component - Grading}

PART I - INDOT Design Manuals

No Recommended Revisions

PART II - INDOT Standard Specifications

No Recommended Revisions

PART III - INDOT Standard Drawings

No Recommended Revisions

PART IV - INDOT Recurring Special Provisions

No Recommended Revisions 


\section{Construction Phase BMP Component - Inlet Protection (Perimeter Barrier)}

PART I - INDOT Design Manuals

No Recommended Revisions

PART II - INDOT Standard Specifications

No Recommended Revisions

PART III - INDOT Standard Drawings

No Recommended Revisions

PART IV - INDOT Recurring Special Provisions

No Recommended Revisions 


\section{Construction Phase BMP Component - Temporary Seeding}

\section{PART I - INDOT Design Manuals}

No Recommended Revisions

\section{PART II - INDOT Standard Specifications}

\begin{tabular}{|l|l|}
\hline Document & INDOT Standard Specifications \\
\hline Reference Location & SECTION 200 - EARTHWORK \\
\hline Reference Location & SECTION 212 - STOCKPILED SELECTED MATERIALS \\
\hline Reference Location & \begin{tabular}{c} 
212.03 Construction Requirements \\
\hline Pdd the following paragraph within the section: \\
Pll selected material stockpiles containing earthen or other erodible materials \\
shall be contained and stabilized. At a minimum, the stockpile shall be \\
surrounded with silt fence perimeter protection for sediment containment. If \\
the selected material is topsoil, vegetation scalpings, or other medium \\
suitable for growing vegetation, the stockpile shall receive temporary seeding \\
within 14 days of inactivity. Locate an access point on the upslope side of the \\
stockpile area. Place stockpiles as far as possible from existing waterbodies \\
as site conditions allow. See Section 205.
\end{tabular} \\
\hline
\end{tabular}

\begin{tabular}{|l|l|}
\hline Document & INDOT Standard Specifications \\
\hline Reference Location & SECTION 200 - EARTHWORK \\
\hline Reference Location & SECTION 203 - EXCAVATION AND EMBANKMENT \\
\hline Reference Location & \begin{tabular}{c} 
203.08 Borrow or Disposal \\
\hline Proposed Revision
\end{tabular} \\
$\begin{array}{c}\text { Add the following text as the second sentence in the third to the last paragraph } \\
\text { regarding the stripping and stockpiling of topsoil in borrow areas: } \\
\text { All topsoil stockpiles shall be placed as far away from existing waterbodies as } \\
\text { site conditions allow. The stockpile shall be surrounded with temporary silt } \\
\text { fence perimeter protection and stabilized with temporary seed and straw } \\
\text { mulch. }\end{array}$ \\
\hline
\end{tabular}

\section{PART III - INDOT Standard Drawings}

No Recommended Revisions

\section{PART IV - INDOT Recurring Special Provisions}

No Recommended Revisions 


\section{Construction Phase BMP Component - Rock Check Dams}

\section{PART I - INDOT Design Manuals}

No Recommended Revisions

\section{PART II - INDOT Standard Specifications}

No Recommended Revisions

\section{PART III - INDOT Standard Drawings}

No Recommended Revisions

\section{PART IV - INDOT Recurring Special Provisions}

No Recommended Revisions 


\section{Construction Phase BMP Component - Sediment Basin}

\section{PART I - INDOT Design Manuals}

\begin{tabular}{|c|c|}
\hline Document & INDOT Design Manual \\
\hline Reference Chapter & Chapter 37 - Temporary Erosion and Sediment Control \\
\hline Reference Section & 37-3.01(04) Sediment Basin \\
\hline Proposed Revision & $\begin{array}{l}\text { - Change "about" in the second sentence of the second paragraph to read "at } \\
\text { least." } \\
\text { - Amend the fifth sentence of the second paragraph as follows: } \\
\text {... minimum water volume equal to the watershed runoff volume resulting from a 2- } \\
\text { year, } 24 \text {-hour storm event. Alternately, in the absence of such a hydrologic } \\
\text { calculation, the designer should provide a minimum water volume of } 252 \mathrm{~m}^{3} / \mathrm{ha}(3600 \\
\mathrm{ft}^{3} \text { /acre) for the watershed tributary to the basin. If the sizing of the sediment basin is } \\
\text { reduced due to space limitations, other measures shall be designed to account for the } \\
\text { reduced capacity of the measure. }\end{array}$ \\
\hline
\end{tabular}

\section{PART II - INDOT Standard Specifications}

No Recommended Revisions

\section{PART III - INDOT Standard Drawings}

No Recommended Revisions

\section{PART IV - INDOT Recurring Special Provisions}

No Recommended Revisions 


\section{Construction Phase BMP Component - Sediment Trap}

\section{PART I - INDOT Design Manuals}

\begin{tabular}{|c|c|}
\hline Document & INDOT Design Manual \\
\hline Reference Chapter & Chapter 37 - Temporary Erosion and Sediment Control \\
\hline Reference Section & 37-3.01(03) Sediment Trap \\
\hline Proposed Revision & $\begin{array}{l}\text { - Add the following sentence as the third sentence of the second paragraph: } \\
\text { If the sizing of the sediment trap is reduced due to space limitations, other } \\
\text { measures shall be designed to account for the reduced capacity of the } \\
\text { measure. }\end{array}$ \\
\hline
\end{tabular}

\section{PART II - INDOT Standard Specifications}

No Recommended Revisions

PART III - INDOT Standard Drawings

No Recommended Revisions

\section{PART IV - INDOT Recurring Special Provisions}

No Recommended Revisions 


\section{Construction Phase BMP Component - Sequencing}

\section{PART I - INDOT Design Manuals}

\begin{tabular}{|c|c|}
\hline Document & INDOT Design Manual \\
\hline Reference Chapter & Chapter 37 - Temporary Erosion and Sediment Control \\
\hline Reference Section & 37-3.06 NEW SECTION \\
\hline Proposed Revision & $\begin{array}{l}\text { - Add the following section: } \\
\text { 37-3.06 Wind Erosion } \\
\text { Measures to prevent erosion and sedimentation resulting from wind should be a } \\
\text { consideration during construction sequencing and construction operations. These } \\
\text { measures include soil roughening and perimeter barriers. Water trucks may be } \\
\text { required to control excessive dust on construction sites. Wind erosion control } \\
\text { measures should be specified by the designer. } \\
\text { Perimeter Barrier } \\
\text { Construction projects should be phased to make use of natural wind barriers where } \\
\text { they exist. When possible tree and brush lines should be maintained. Where tree and } \\
\text { brush lines are designated for removal, construction sequencing of such should aim to } \\
\text { reduce exposure of the site to wind erosion. }\end{array}$ \\
\hline
\end{tabular}

\begin{tabular}{|l|l|}
\hline Document & INDOT Design Manual \\
\hline Reference Chapter & Chapter 37 - Temporary Erosion and Sediment Control \\
\hline Reference Section & 37-4.0 NEW SECTION \\
\hline Proposed Revision & $\begin{array}{l}\text { 37-4.0 CONSTRUCTION SEQUENCING } \\
\text { The designer of the Stormwater Pollution Prevention Plan should indicate on the plans } \\
\text { the anticipated sequence of activities describing implementation of stormwater quality } \\
\text { measures relative to land disturbing activities. Changes to the proposed sequencing } \\
\text { shown on the plans made the Contractor to match actual means, methods, and } \\
\text { equipment would be the responsibility of the Contractor. These changes shall be } \\
\text { submitted to and approved by the appropriate permitting authority. }\end{array}$ \\
\hline
\end{tabular}

\section{PART II - INDOT Standard Specifications}

No Recommended Revisions

\section{PART III - INDOT Standard Drawings}

No Recommended Revisions

\section{PART IV - INDOT Recurring Special Provisions}

No Recommended Revisions 


\section{Construction Phase BMP Component - Silt Fences}

\section{PART I - INDOT Design Manuals}

No Recommended Revisions

\section{PART II - INDOT Standard Specifications}

\begin{tabular}{|l|l|}
\hline Document & INDOT Standard Specifications \\
\hline Reference Location & SECTION 200 - EARTHWORK \\
\hline Reference Location & SECTION 212 - STOCKPILED SELECTED MATERIALS \\
\hline Reference Location & \begin{tabular}{c} 
212.03 Construction Requirements \\
\hline Proposed Revision
\end{tabular} \\
& $\begin{array}{l}\text { All selected material stockpiles containing earthen or other erodible materials } \\
\text { shall be contained and stabilized. At a minimum, the stockpile shall be } \\
\text { surrounded with silt fence perimeter protection for sediment containment. If } \\
\text { the selected material is topsoil, vegetation scalpings, or other medium } \\
\text { suitable for growing vegetation, the stockpile shall receive temporary seeding } \\
\text { within 14 days of inactivity. Locate an access point on the upslope side of the } \\
\text { stockpile area. Place stockpiles as far as possible from existing waterbodies } \\
\text { as site conditions allow. See Section 205. }\end{array}$ \\
\hline
\end{tabular}

\begin{tabular}{|l|l|}
\hline Document & INDOT Standard Specifications \\
\hline Reference Location & SECTION 200 - EARTHWORK \\
\hline Reference Location & SECTION 201 - CLEARING AND GRUBBING \\
\hline Reference Location & 201.02 General (Construction Requirements) \\
\hline Proposed Revision & $\begin{array}{c}\text { Add the following text as the third sentence: } \\
\text { Erosion and sediment control measures (perimeter protection) shall be } \\
\text { installed prior to initiating land disturbance, including clearing and grubbing } \\
\text { operations. }\end{array}$ \\
\hline
\end{tabular}

\begin{tabular}{|l|l|}
\hline Document & INDOT Standard Specifications \\
\hline Reference Location & SECTION 200 - EARTHWORK \\
\hline Reference Location & SECTION 203 - EXCAVATION AND EMBANKMENT \\
\hline Reference Location & \begin{tabular}{c} 
203.08 Borrow or Disposal \\
\hline Proposed Revision
\end{tabular} \\
$\begin{array}{c}\text { Add the following text as the second sentence in the third to the last paragraph } \\
\text { regarding the stripping and stockpiling of topsoil in borrow areas: }\end{array}$ \\
$\begin{array}{c}\text { All topsoil stockpiles shall be placed as far away from existing waterbodies as } \\
\text { site conditions allow. The stockpile shall be surrounded with temporary silt } \\
\text { fence perimeter protection and stabilized with temporary seed and straw } \\
\text { mulch. }\end{array}$ \\
\hline
\end{tabular}




\section{PART III - INDOT Standard Drawings}

No Recommended Revisions

\section{PART IV - INDOT Recurring Special Provisions}

No Recommended Revisions 


\section{Construction Phase BMP Component - Soil Roughening}

\section{PART I - INDOT Design Manuals}

\begin{tabular}{|c|c|}
\hline Document & INDOT Design Manual \\
\hline Reference Chapter & Chapter 37 - Temporary Erosion and Sediment Control \\
\hline Reference Section & 37-3.06 NEW SECTION \\
\hline Proposed Revision & $\begin{array}{l}\text { - Add the following section: } \\
\text { 37-3.06 Wind Erosion } \\
\text { Measures to prevent erosion and sedimentation resulting from wind should be a } \\
\text { consideration during construction sequencing and construction operations. These } \\
\text { measures include soil roughening and perimeter barriers. Water trucks may be } \\
\text { required to control excessive dust on construction sites. Wind erosion control } \\
\text { measures should be specified by the designer. } \\
\text { Soil Roughening } \\
\text { Exposed surfaces or the finished surface should be track-walked up and down the } \\
\text { slope with a dozer or other tracked equipment, rather than left completely smooth. } \\
\text { Track-walking should not be performed parallel to the contour, as this would actually } \\
\text { increase erosion. }\end{array}$ \\
\hline
\end{tabular}

\begin{tabular}{|l|l|}
\hline Document & INDOT Standard Specifications \\
\hline Reference Location & SECTION 200 - EARTHWORK \\
\hline Reference Location & SECTION 203 - EXCAVATION AND EMBANKMENT \\
\hline Reference Location & $\begin{array}{r}\text { 203.09 General Requirements (Construction Requirements) } \\
\hline \text { Proposed Revision }\end{array} \begin{array}{l}\text { In the first sentence of the fourth to the last paragraph regarding soil roughening, } \\
\text { the series of ridges and depressions should be created "parallel to the contour" } \\
\text { instead of parallel to the roadway. }\end{array}$ \\
\hline
\end{tabular}

\section{PART II - INDOT Standard Specifications}

No Recommended Revisions

\section{PART III - INDOT Standard Drawings}

No Recommended Revisions

\section{PART IV - INDOT Recurring Special Provisions}

No Recommended Revisions 


\section{Construction Phase BMP Component - Straw Bale Ditch Check}

\section{PART I - INDOT Design Manuals}

\begin{tabular}{|c|c|}
\hline Document & INDOT Design Manual \\
\hline Reference Chapter & Chapter 37 - Temporary Erosion and Sediment Control \\
\hline Reference Section & 37-3.03(01) Check Dams \\
\hline Proposed Revision & $\begin{array}{l}\text { - Add the following sentence to the end of the paragraph: } \\
\text { Within the construction clear zone, straw bales, fiber wattle rolls, or other approved } \\
\text { means, shall be used instead of riprap. }\end{array}$ \\
\hline
\end{tabular}

\begin{tabular}{|l|l|}
\hline Document & INDOT Standard Drawings \\
\hline Reference Location & Section 200 - Earthwork \\
\hline Reference Drawing & E 205-TECD-02 (M 205-TECD-02) \\
\hline Code Meaning & TECD - Temporary Erosion Control Ditch \\
\hline Drawing Title & $\begin{array}{l}\text { Temporary Check Dam, Straw Bales } \\
\text { Proposed Revision }\end{array}$ \\
$\begin{array}{l}\text { Revise the notes on this drawing to state (general note and drawing note): } \\
\text { elevation of the end bale shall be a minimum of } 6 \text { inches above the top elevation } \\
\text { of the lowest bale. The ditch checks shall be spaced at intervals such that the top } \\
\text { of the downstream check is at the same elevation as the toe invert of the adjacent } \\
\text { upstream check. }\end{array}$ \\
\hline
\end{tabular}

\section{PART II - INDOT Standard Specifications}

\begin{tabular}{|c|c|}
\hline Document & INDOT Standard Specifications \\
\hline Reference Location & SECTION 200 - EARTHWORK \\
\hline Reference Location & SECTION 205 - TEMPORARY EROSION AND SEDIMENT CONTROL \\
\hline Reference Location & 205.03 Control Measures \\
\hline Proposed Revision & $\begin{array}{l}\text { - Modify 205.03(c) about check dams to state: } \\
\text { (c) Check Dams. Check dams shall at a minimum be constructed of } \\
\text { revetment riprap or straw bales as shown on the Standard Drawings. } \\
\text { Additional check dam construction requirements may be shown on the plans. } \\
\text { - Modify 205.03(c)(2) about straw bales ditch checks to state the following: } \\
\text { 2. Straw Bales. Straw bales shall be embedded and staked as shown on the } \\
\text { plans. At a minimum, the bales must extend across the full width of the swale } \\
\text { or ditch. The bottom elevation of the end bale shall be a minimum of } 6 \text { inches } \\
\text { above the top elevation of the lowest bale. The ditch checks shall be spaced } \\
\text { at intervals such that the top of the downstream check is at the same } \\
\text { elevation as the toe invert of the adjacent upstream check. Adjacent bales } \\
\text { shall be chinked to eliminate gaps between the bales. Bales shall be placed } \\
\text { such that the bindings are parallel to and not in contact with the ground. }\end{array}$ \\
\hline
\end{tabular}




\begin{tabular}{|l|l|}
\hline Document & INDOT Standard Specifications \\
\hline Reference Location & SECTION 200 - EARTHWORK \\
\hline Reference Location & SECTION 205 - TEMPORARY EROSION AND SEDIMENT CONTROL \\
\hline Reference Location & \begin{tabular}{l} 
205.07 Basis of Payment \\
\hline Proposed Revision
\end{tabular} \\
$\begin{array}{l}\text { Modify the note in the third to last paragraph about check dams under the list of } \\
\text { pay items to include temporary check dam, straw bales and include geotextile on } \\
\text { the list of materials included in the cost of the pay item. }\end{array}$ \\
\hline
\end{tabular}

\section{PART III - INDOT Standard Drawings}

No Recommended Revisions

\section{PART IV - INDOT Recurring Special Provisions}

No Recommended Revisions 


\section{Construction Phase BMP Component - Straw Mulch}

\section{PART I - INDOT Design Manuals}

No Recommended Revisions

\section{PART II - INDOT Standard Specifications}

No Recommended Revisions

PART III - INDOT Standard Drawings

No Recommended Revisions

PART IV - INDOT Recurring Special Provisions

No Recommended Revisions 


\section{Construction Phase BMP Component - Structural Methods}

PART I - INDOT Design Manuals

No Recommended Revisions

PART II - INDOT Standard Specifications

No Recommended Revisions

PART III - INDOT Standard Drawings

No Recommended Revisions

PART IV - INDOT Recurring Special Provisions

No Recommended Revisions 


\section{Construction Phase BMP Component - Surface Water Diversion}

PART I - INDOT Design Manuals

No Recommended Revisions

PART II - INDOT Standard Specifications

No Recommended Revisions

PART III - INDOT Standard Drawings

No Recommended Revisions

PART IV - INDOT Recurring Special Provisions

No Recommended Revisions 


\section{Construction Phase BMP Component - Turbidity Curtain}

\section{PART I - INDOT Design Manuals}

\begin{tabular}{|l|l|}
\hline Document & INDOT Design Manual \\
\hline Reference Chapter & Chapter 37 - Temporary Erosion and Sediment Control \\
\hline Reference Section & 37-3.01 Protection of Adjacent Areas \\
\hline Proposed Revision & $\bullet \quad$ Add "turbidity curtain barriers" to the end of the first paragraph. \\
\hline
\end{tabular}

\begin{tabular}{|c|c|}
\hline Document & INDOT Design Manual \\
\hline Reference Chapter & Chapter 37 - Temporary Erosion and Sediment Control \\
\hline Reference Section & $37-3.01(05)$ \\
\hline Proposed Revision & $\begin{array}{l}\text { - Add the following sections: } \\
\text { 37-3.01(05) Turbidity Curtain Barriers } \\
\text { The purpose of a turbidity curtain is to prevent the flow and/or washing of disturbed } \\
\text { debris into a water source: stream, river, pool, lake or reservoir. In essence, a turbidity } \\
\text { curtain is a floating silt fence. Turbidity curtains are manufactured to specification. The } \\
\text { variables involved in determining such specifications are: water flow rate, depth of } \\
\text { channel to be crossed or controlled, desired filtering properties of the geotextile } \\
\text { curtain, tide action (if any), and the length of time the curtain is to be utilized. } \\
\text { A turbidity curtain should not be used as a dam. It will not "hold back" the water flow of } \\
\text { a river or stream, but it will control the amount of clouding and silt migration that is } \\
\text { caused by construction. } \\
\text { Turbidity curtain barriers are useful when working on the bank of an existing } \\
\text { waterbody or in the rarer instance where the proposed work encroaches into the } \\
\text { waterbody. }\end{array}$ \\
\hline
\end{tabular}

\begin{tabular}{|c|c|}
\hline Document & INDOT Design Manual \\
\hline Reference Chapter & Chapter 37 - Temporary Erosion and Sediment Control \\
\hline Reference Section & 37-3.04(03) NEW SECTION \\
\hline Proposed Revision & $\begin{array}{l}\text { - Add the following section: } \\
\text { 37-3.04(03) Turbidity Curtain Barriers Alongside Streams } \\
\text { When a pond, lake, or perennial stream is adjacent to an exposed fill slope and it is } \\
\text { necessary to work within the stream itself, the stream should be protected from } \\
\text { sediment by the use of a turbidity curtain barriers alongside the stream as described in } \\
\text { Section 37-3.01(05). }\end{array}$ \\
\hline
\end{tabular}




\begin{tabular}{|c|c|}
\hline Document & INDOT Standard Drawings \\
\hline Reference Location & Section 200 - Earthwork \\
\hline Reference Drawing & E 205-TECP-03 (M 205-TECP-03) (Now Unassigned) (NEW DRAWING) \\
\hline Code Meaning & TECP - Temporary Erosion Control Perimeter \\
\hline Drawing Title & Temporary Turbidity Curtain (Silt Boom), Flowing Water \\
\hline Proposed Revision & $\begin{array}{l}\text { - A new drawing should be created for a temporary turbidity curtain (silt boom) } \\
\text { This drawing should contain three types of installation configurations and the } \\
\text { following details: } \\
\text { - Type I configuration for protected areas where there is no current ano } \\
\text { the area enclosed by the turbidity curtain is protected from wind and } \\
\text { wave action } \\
\text { - Type II configuration for areas with mild wind or wave action or where a } \\
\text { slow to medium current (less than } 3.5 \text { feet per second) is expected } \\
\text { - Type III configuration for areas that will potentially be subjected to } \\
\text { significant wind or wave action or where a considerable current (up to } 5 \\
\text { feet per second) is expected } \\
\text { - A section view of the turbidity curtain installation showing the curtain, } \\
\text { end points, external stakes or anchors (as recommended by } \\
\text { manufacturer), buoys, and flashing warning lights as necessary (for } \\
\text { navigable waters). } \\
\text { - This detail may also contain the material specifications for the curtain } \\
\text { fabric and the floatation devices. Strength requirements of seams, load } \\
\text { lines, and external anchors may also be included. }\end{array}$ \\
\hline
\end{tabular}

\begin{tabular}{|l|l|}
\hline Document & INDOT Standard Specifications \\
\hline Reference Location & SECTION 100 - GENERAL PROVISIONS \\
\hline Reference Location & SECTION 108 - PROSECUTION AND PROGRESS \\
\hline Reference Location & $\begin{array}{c}\text { 108.04 Prosecution of Work } \\
\text { Proposed Revision }\end{array}$ \\
$\begin{array}{l}\text { (a) When work areas are located in or adjacent to bodies of water, a turbidity } \\
\text { curtain (silt boom) or other comparable sediment control measure should be } \\
\text { used. If site conditions prevent the use of a turbidity curtain (silt boom), such } \\
\text { areas shall be separated by a dike or other acceptable barrier to keep } \\
\text { sediment contained. Sediment disturbance of these bodies of water shall be } \\
\text { minimized during the construction and removal of such barriers. }\end{array}$ \\
\hline
\end{tabular}




\begin{tabular}{|l|l|}
\hline Document & INDOT Standard Specifications \\
\hline Reference Location & SECTION 200 - EARTHWORK \\
\hline Reference Location & SECTION 202 - REMOVAL OF STRUCTURES AND OBSTRUCTIONS \\
\hline Reference Location & \begin{tabular}{c} 
202.03 Removal of Bridges, Culverts, and Other Drainage Structures \\
\hline Proposed Revision
\end{tabular} \\
$\begin{array}{c}\text { When work areas are located in or adjacent to bodies of water, a turbidity } \\
\text { curtain (silt boom) or other comparable sediment control measure should be } \\
\text { used. If site conditions prevent the use of a turbidity curtain (silt boom), such } \\
\text { areas shall be separated by a dike or other barrier to keep contained. } \\
\text { Sediment disturbance of these bodies of water shall be minimized during the } \\
\text { construction and removal of such barriers. }\end{array}$ \\
\hline
\end{tabular}

\section{PART II - INDOT Standard Specifications}

\begin{tabular}{|c|c|}
\hline Document & INDOT Standard Specifications \\
\hline Reference Location & SECTION 200 - EARTHWORK \\
\hline Reference Location & SECTION 205 - TEMPORARY EROSION AND SEDIMENT CONTROL \\
\hline Reference Location & 205.03 Control Measures \\
\hline Proposed Revision & $\begin{array}{l}\text { - Add the following as new section 205.03(o) Turbidity Curtain (Silt Boom): } \\
\text { (o) Turbidity Curtain (Silt Boom). The manufacturer's recommendations } \\
\text { shall be followed with regard to shipping, handling, storage, installation, and } \\
\text { protection from direct sunlight. The geotextile will be rejected if it has defects, } \\
\text { tears, punctures, flaws, deterioration, or damage incurred during } \\
\text { manufacturing, transportation, storage, or installation. Each roll shall be } \\
\text { labeled or tagged to provide product identification. } \\
\text { Seaming of the floating curtain shall be completed to develop the full strength } \\
\text { of the product. External or bottom anchors shall be installed as } \\
\text { recommended by the manufacturer. The curtain shall be a bright color and } \\
\text { should be installed parallel to the direction of flow. } \\
\text { The original copies of all necessary current manufacturers' installation } \\
\text { manuals shall be provided prior to installation. }\end{array}$ \\
\hline Document & INDOT Standard Specifications \\
\hline Reference Location & SECTION 200 - EARTHWORK \\
\hline Reference Location & SECTION 205 - TEMPORARY EROSION AND SEDIMENT CONTROL \\
\hline Reference Location & 205.06 Method of Measurement \\
\hline Proposed Revision & $\begin{array}{l}\text { - Modify this section and the method of measurement information: } \\
\text { Turbidity curtains (silt booms) will be measured by the meter (linear foot) }\end{array}$ \\
\hline
\end{tabular}




\begin{tabular}{|c|c|}
\hline Document & INDOT Standard Specifications \\
\hline Reference Location & SECTION 200 - EARTHWORK \\
\hline Reference Location & SECTION 205 - TEMPORARY EROSION AND SEDIMENT CONTROL \\
\hline Reference Location & 205.07 Basis of Payment \\
\hline Proposed Revision & $\begin{array}{l}\text { - Modify this section and add the basis of payment information that will be used } \\
\text { once construction quantities are accepted. } \\
\text { Turbidity curtains (silt booms) will be paid for by the meter (linear foot) } \\
\text { - Add the following items to the list of pay items: } \\
\text { Temporary Turbidity Curtains (silt booms)........................................m (LFT) } \\
\text { - Add the following exception under the list of pay items: } \\
\text { The cost of seaming, stakes, posts, anchors and all necessary incidentals for } \\
\text { the construction and removal of turbidity curtains (silt booms) shall be } \\
\text { included in the cost of the turbidity curtains (silt booms). }\end{array}$ \\
\hline
\end{tabular}

\begin{tabular}{|l|l|}
\hline Document & INDOT Standard Specifications \\
\hline Reference Location & SECTION 200 - EARTHWORK \\
\hline Reference Location & SECTION 206-STRUCTURE EXCAVATION \\
\hline Reference Location & 206.09 Cofferdams and Temporary Construction Dikes \\
\hline & Add the following text as the second paragraph: \\
& When in-channel sediment control measures have not been specified by the \\
Plans, they must be included in the amended SWPPP required under Section \\
108.03. Appropriate in-channel control measures, such as a turbidity curtain \\
(silt boom) Section 205.03(0) shall be used.
\end{tabular}

\begin{tabular}{|l|l|}
\hline Document & INDOT Standard Specifications \\
\hline Reference Location & SECTION 200 - EARTHWORK \\
\hline Reference Location & SECTION 206-STRUCTURE EXCAVATION \\
\hline Reference Location & \begin{tabular}{c}
206.11 Basis of Payment \\
\hline Proposed Revision
\end{tabular} \\
$\begin{array}{l}\text { If turbidity curtains are required, they shall be paid for at a contract unit price } \\
\text { according to Section 205.07. If no contract unit price has been established } \\
\text { for this item, the Contractor shall promptly provide a proposed contract unit } \\
\text { price to include all costs related to labor, material, overhead and profit prior to } \\
\text { implement the turbidity curtain. The Contractor shall not install the turbidity } \\
\text { curtain, nor perform any work in the area to be protected by the turbidity } \\
\text { curtain, until a contract unit price has been negotiated for this item. }\end{array}$ \\
\hline
\end{tabular}




\begin{tabular}{|c|c|c|c|}
\hline Document & \multicolumn{3}{|c|}{ INDOT Standard Specifications } \\
\hline Reference Location & \multicolumn{3}{|c|}{ SECTION 900 - MATERIALS DETAILS } \\
\hline Reference Location & \multicolumn{3}{|c|}{ SECTION 918 - SOIL FABRICS } \\
\hline Reference Location & \multicolumn{3}{|c|}{918.06 - TUBIDITY CURTAIN (SILT BOOM) } \\
\hline & \multicolumn{3}{|r|}{$\begin{array}{l}\text { om) should be constructed by } \\
\text { on the water flow rate, depth } \\
\text { ng properties of the geotextile } \\
\text { curtain is to be utilized. } \\
\text { th the requirements for the } \\
\text { lymer impregnated to negate } \\
\text { led pockets shall be sewn or } \\
\text { hts. Panel ends shall have } \\
\text { Connections between panels } \\
\text { ent flow through the joint. }\end{array}$} \\
\hline \multirow{10}{*}{ Proposed Revision } & TEST & METHOD & REQUIREMENTS \\
\hline & Tensile Strength & $\begin{array}{l}\text { Grab Tensile Strength } \\
\text { ASTM D } 4632\end{array}$ & $1200 N(270 \mathrm{lbs})$ \\
\hline & Elongation & $\begin{array}{l}\text { Grab Tensile Strength } \\
\text { ASTM D } 4632\end{array}$ & $25 \%$ \\
\hline & Seam Strength & $\begin{array}{l}\text { Grab Tensile Strength } \\
\text { ASTM D } 4632\end{array}$ & $1070 \mathrm{~N}(240 \mathrm{lbs})$ \\
\hline & Bursting Strength & $\begin{array}{l}\text { Mullen Burst } \\
\text { ASTM D } 3786\end{array}$ & 2.76 MPa (400 psi) \\
\hline & Puncture Strength & ASTM D 4833 & $445 \mathrm{~N}(100 \mathrm{lbs})$ \\
\hline & Trapezoid Tear & ASTM D 4533 & $445 \mathrm{~N}(100 \mathrm{lbs})$ \\
\hline & $\begin{array}{l}\text { Ultraviolet Degradation } \\
\text { At } 150 \mathrm{~h}\end{array}$ & ASTM D 4355 & $70 \%$ strength retained \\
\hline & $\begin{array}{l}\text { Apparent Opening Size } \\
\text { (AOS) }\end{array}$ & ASTM D 4751 & $0.50 \mathrm{~mm}$ \\
\hline & Permeability & $\begin{array}{l}\text { ASTM D } 4491 \\
\text { (Permittivity) }\end{array}$ & $0.6 \mathrm{~s}^{-1}(\max )$ \\
\hline
\end{tabular}

(b) Flotation. Flotation devices shall be closed-cell polystyrene. The buoyancy (volume) required will depend upon site conditions; however, sufficient freeboard shall be provided to prevent overtopping.

(c) Stakes. Stakes, when used to assist in maintaining alignment of the curtain, shall be hardwood or steel with sufficient length and cross-section to support the curtain. External supports may be used; however, embedment depth shall not be less than 1.5 feet.

(d) Hardware. All hardware such as stakes, ballast chain, connection bolts, reinforcement plates, and tension cables shall be galvanized, stainless steel, aluminum, or otherwise corrosion resistant. The ballast chain shall have sufficient mass to maintain the geosynthetic in a vertical position, but shall not be less than $0.7 \mathrm{lb} / \mathrm{ft}$. 


\begin{tabular}{|l|l|}
\hline Document & INDOT Standard Specifications \\
\hline Reference Location & SECTION 200 - EARTHWORK \\
\hline Reference Location & SECTION 205 - TEMPORARY EROSION AND SEDIMENT CONTROL \\
\hline Reference Location & \begin{tabular}{c} 
205.02 Materials \\
\hline Proposed Revision
\end{tabular} \\
& $\begin{array}{c}\text { Add the following items alphabetically to the list of materials. Add the appropriate } \\
\text { section reference number: } \\
\text { Turbidity Curtain (Silt Boom) }\end{array}$ \\
\hline
\end{tabular}

\section{PART III - INDOT Standard Drawings}

No Recommended Revisions

\section{PART IV - INDOT Recurring Special Provisions}

No Recommended Revisions 


\section{Construction Phase BMP Component - Vehicle Tracking Pads}

\section{PART I - INDOT Design Manuals}

\begin{tabular}{|l|c|}
\hline Document & INDOT Design Manual \\
\hline Reference Chapter & Chapter 37 - Temporary Erosion and Sediment Control \\
\hline Reference Section & 37-3.01 Protection of Adjacent Areas \\
\hline Proposed Revision & $\bullet \quad$ Add "vehicle tracking pads" to the end of the first paragraph. \\
\hline
\end{tabular}

\begin{tabular}{|c|c|}
\hline Document & INDOT Design Manual \\
\hline Reference Chapter & Chapter 37 - Temporary Erosion and Sediment Control \\
\hline Reference Section & 37-3.01(06) NEW SECTIONS \\
\hline Proposed Revision & $\begin{array}{l}\text { - Add the following sections: } \\
\text { 37-3.01(06) Vehicle Tracking Pad } \\
\text { A vehicle tracking pad may be necessary at construction access locations to reduce } \\
\text { the amount of mud transported off-site by vehicles. The pad shall be a minimum of } 50 \\
\text { feet long. A geotextile fabric should be used under the riprap, uniform B to minimize } \\
\text { the migration of stone into the underlying soil by heavy vehicle loads. }\end{array}$ \\
\hline
\end{tabular}

\section{PART II - INDOT Standard Specifications}

\begin{tabular}{|l|l|}
\hline Document & INDOT Standard Specifications \\
\hline Reference Location & SECTION 200 - EARTHWORK \\
\hline Reference Location & SECTION 205 - TEMPORARY EROSION AND SEDIMENT CONTROL \\
\hline Reference Location & 205.03 Control Measures \\
\hline Proposed Revision & $\begin{array}{c}\text { Add the following as new section 205.03(q) Vehicle Tracking Pad: } \\
\text { (q) Vehicle Tracking Pad. Vehicle tracking pads shall be constructed of } \\
\text { riprap, uniform B as shown on the plans. }\end{array}$ \\
\hline
\end{tabular}

\begin{tabular}{|l|c|}
\hline Document & INDOT Standard Specifications \\
\hline Reference Location & SECTION 200 - EARTHWORK \\
\hline Reference Location & SECTION 205 - TEMPORARY EROSION AND SEDIMENT CONTROL \\
\hline Reference Location & \begin{tabular}{c} 
205.06 Method of Measurement \\
\hline Proposed Revision
\end{tabular} \\
$\begin{array}{c}\text { Modify this section and the method of measurement information: } \\
\text { aggregate used. }\end{array}$ \\
\hline
\end{tabular}




\begin{tabular}{|c|c|}
\hline Document & INDOT Standard Specifications \\
\hline Reference Location & SECTION 200 - EARTHWORK \\
\hline Reference Location & SECTION 205 - TEMPORARY EROSION AND SEDIMENT CONTROL \\
\hline Reference Location & 205.07 Basis of Payment \\
\hline Proposed Revision & $\begin{array}{l}\text { - Modify this section and add the basis of payment information that will be used } \\
\text { once construction quantities are accepted. } \\
\text { Coarse aggregate for vehicle tracking pad will be paid for per megagram (ton) } \\
\text { for each type of aggregate used. } \\
\text { - Add the following items to the list of pay items: } \\
\text { Riprap, Uniform B, for vehicle tracking pad........................Mg(TON) } \\
\text { Add the following exception under the list of pay items: } \\
\text { The cost of geotextile shall be included in the cost of the vehicle tracking pad. }\end{array}$ \\
\hline
\end{tabular}




\title{
PART III - INDOT Standard Drawings
}

\begin{tabular}{|c|c|}
\hline Document & INDOT Standard Drawings \\
\hline Reference Location & Section 200 - Earthwork \\
\hline Reference Drawing & (NEW DRAWING) \\
\hline Code Meaning & Needs Code Assigned \\
\hline Drawing Title & Vehicle Tracking Pad \\
\hline Proposed Revision & $\begin{array}{l}\text { - A new drawing should be created for a vehicle tracking pad. A vehicle tracking } \\
\text { pad is defined by a point of entrance/exit to a construction site that is stabilized to } \\
\text { reduce the tracking of mud and dirt onto public roads by construction vehicles. } \\
\text { - A vehicle tracking pad is sediment control in the form of soil tracking control. This } \\
\text { drawing should contain the following details: } \\
\text { - Vehicle tracking pads are constructed of aggregate. It is recommended } \\
\text { the construction entrance consist of } 6 \text { inches of INDOT riprap, uniform B } \\
\text { placed over } 6 \text { inches of crushed INDOT No. } 53 \text { stone. } \\
\text { - A note should be added to state: "If INDOT riprap, uniform B is not } \\
\text { available locally, INDOT No. } 2 \text { stone may be substituted. Additional } \\
\text { sediment tracking control measures may be needed due to reduction of } \\
\text { aggregate size." } \\
\text { - The aggregate should be placed over a geotextile fabric. } \\
\text { - The minimum dimensions of the construction entrance should be } 50 \text { feet } \\
\text { long by } 20 \text { feet wide. Appropriate turning radii should be included at the } \\
\text { roadway access points. Additional width may be required to allow for } \\
\text { the passing of vehicles. } \\
\text { - A note should be added to state: "Periodic dressing of the top layer with } \\
\text { additional aggregate may be required." } \\
\text { - A note should be added to state: "Additional sediment tracking control } \\
\text { measures should be added as required to prevent the tracking of mud or } \\
\text { dirt onto the roadway. Such measures may include tire washes, rumble } \\
\text { racks constructed of steel panels with ridges, street sweeping, or } \\
\text { vacuuming." } \\
\text { - A note should be added to state: "Add drainage pipes beneath the } \\
\text { temporary construction entrance as needed to maintain ditch or other } \\
\text { cross-flow drainage." }\end{array}$ \\
\hline
\end{tabular}

\section{PART IV - INDOT Recurring Special Provisions}

\author{
No Recommended Revisions
}




\section{Post-Construction Phase BMP Recommendations}




\section{General:}

This Section is one part of a comprehensive review of INDOT documentation related to INDOT's Storm Water Quality Master Plan (SWQMP). The comments in this Section are related to Post-Construction Phase Best Management Practices (BMPs).

\section{Documents Covered:}

- INDOT Design Manuals

- INDOT Standard Specifications

- INDOT Recurring Special Provisions

- INDOT Standard Drawings

\section{Organization:}

Specific recommended revisions and additions to the above listed documents are summarized by BMP as they pertain to individual measures. Some of the recommended BMPs do not require specific revisions to INDOT documents for inclusion within INDOT projects. BMPs that are recommended for use at INDOT roadways and facilities for the Post-Construction Phase are listed in Table 1.

\section{Table 1: Post - Construction Phase BMPs}

\begin{tabular}{|l|}
\hline \multicolumn{1}{|c|}{ Post - Construction Phase BMPs } \\
\hline \hline Bioretention \\
\hline Filter Strip \\
\hline Infiltration Basin \\
\hline Infiltration Trench \\
\hline Native Seeding (Permanent) \\
\hline Riprap \\
\hline Storage Facility - Dry Pond \\
\hline Storage Facility - Extended Detention Pond \\
\hline Storage Facility - Wet Pond \\
\hline Stormwater Wetland (Native Vegetation) \\
\hline Turf Reinforcement Mat (TRM) \\
\hline Water Quality Dry Swale \\
\hline Water Quality Structures (Hydrodynamic Separators) \\
\hline Water Quality Wet Swale \\
\hline
\end{tabular}




\section{Post-Construction Phase BMP Component - Bioretention}

\section{PART I - INDOT Design Manuals}

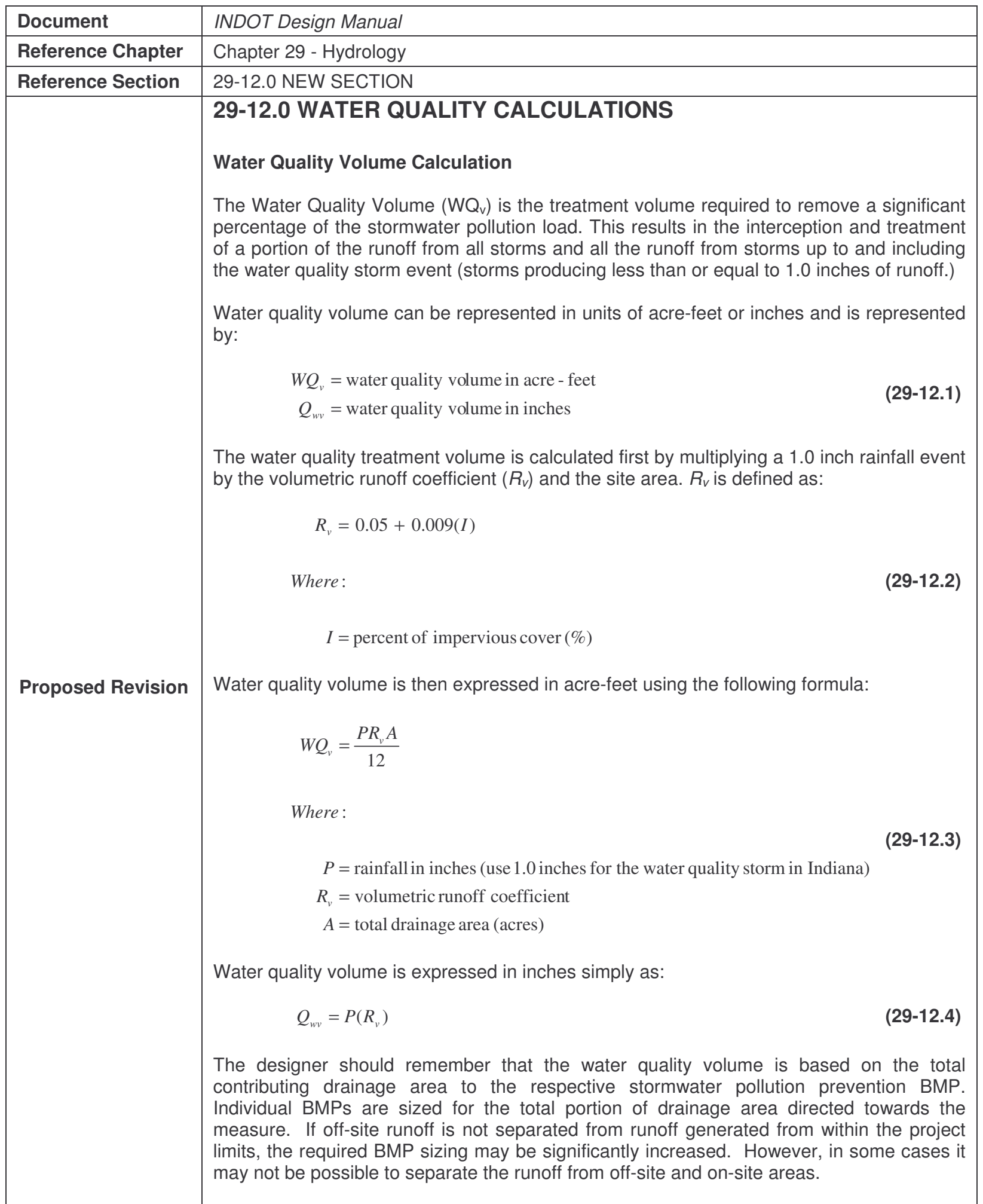




\section{PART II - INDOT Standard Specifications}

No Recommended Revisions

PART III - INDOT Standard Drawings

No Recommended Revisions

\section{PART IV - INDOT Recurring Special Provisions}

No Recommended Revisions 


\section{Post-Construction Phase BMP Component - Filter Strip}

PART I - INDOT Design Manuals

No Recommended Revisions

PART II - INDOT Standard Specifications

No Recommended Revisions

PART III - INDOT Standard Drawings

No Recommended Revisions

PART IV - INDOT Recurring Special Provisions

No Recommended Revisions 


\section{Post-Construction Phase BMP Component - Infiltration Basin}

\section{PART I - INDOT Design Manuals}

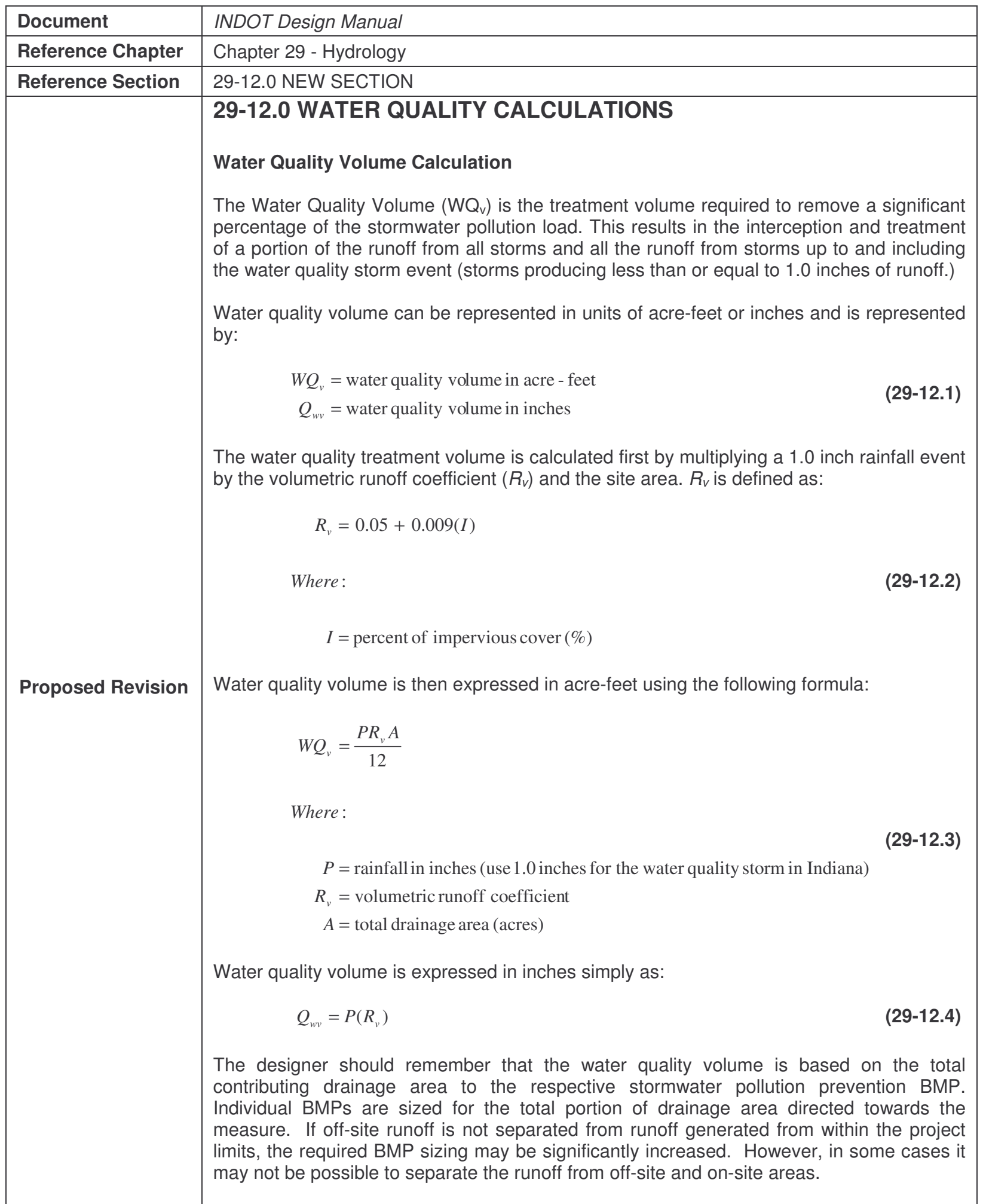




\section{PART II - INDOT Standard Specifications}

No Recommended Revisions

\section{PART III - INDOT Standard Drawings}

No Recommended Revisions

PART IV - INDOT Recurring Special Provisions

No Recommended Revisions 


\section{Post-Construction Phase BMP Component - Infiltration Trench}

\section{PART I - INDOT Design Manuals}

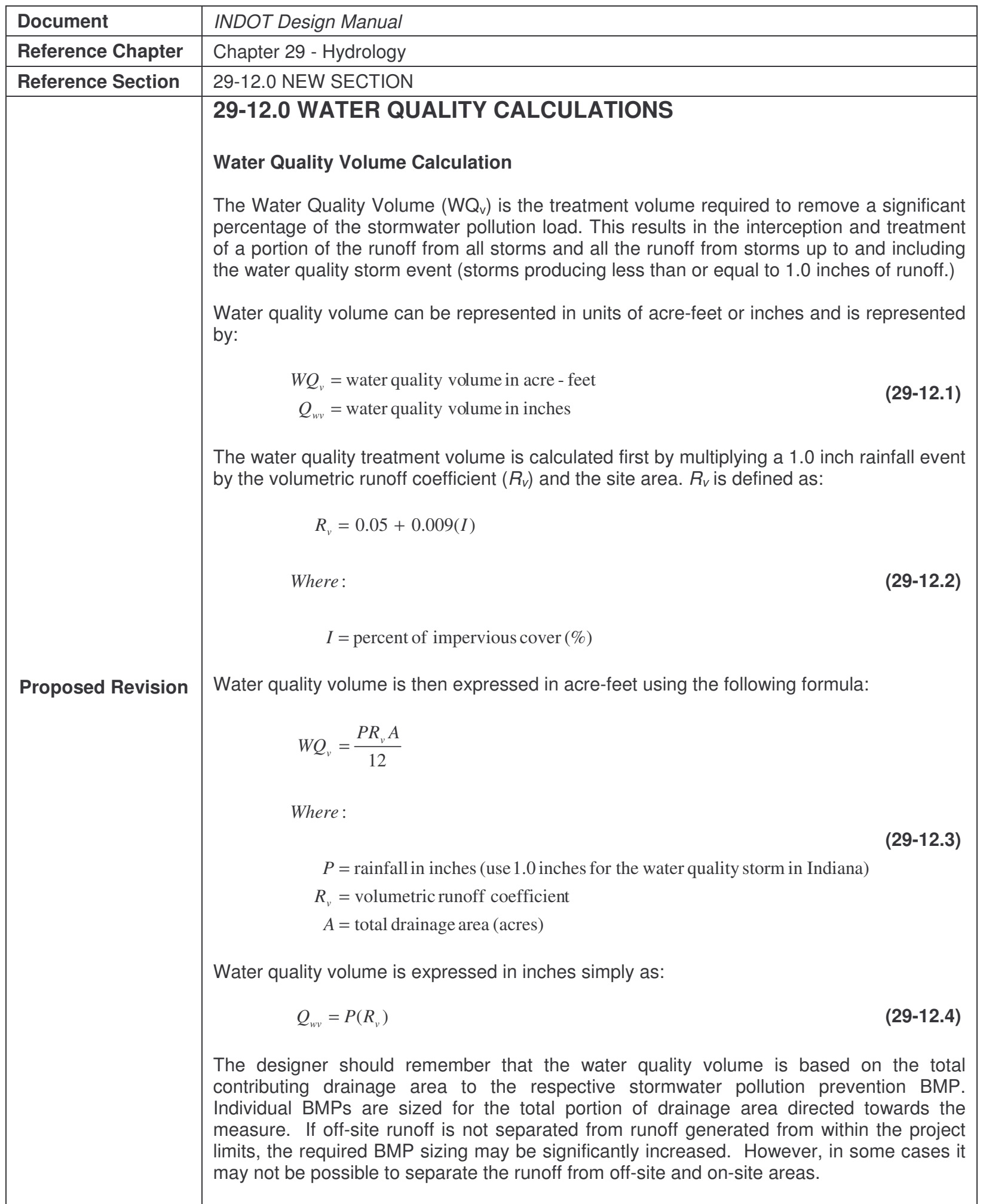




\begin{tabular}{|c|c|}
\hline Document & INDOT Design Manual \\
\hline Reference Chapter & Chapter 29 - Hydrology \\
\hline Reference Section & 29-12.0 NEV \\
\hline Proposed Revision & 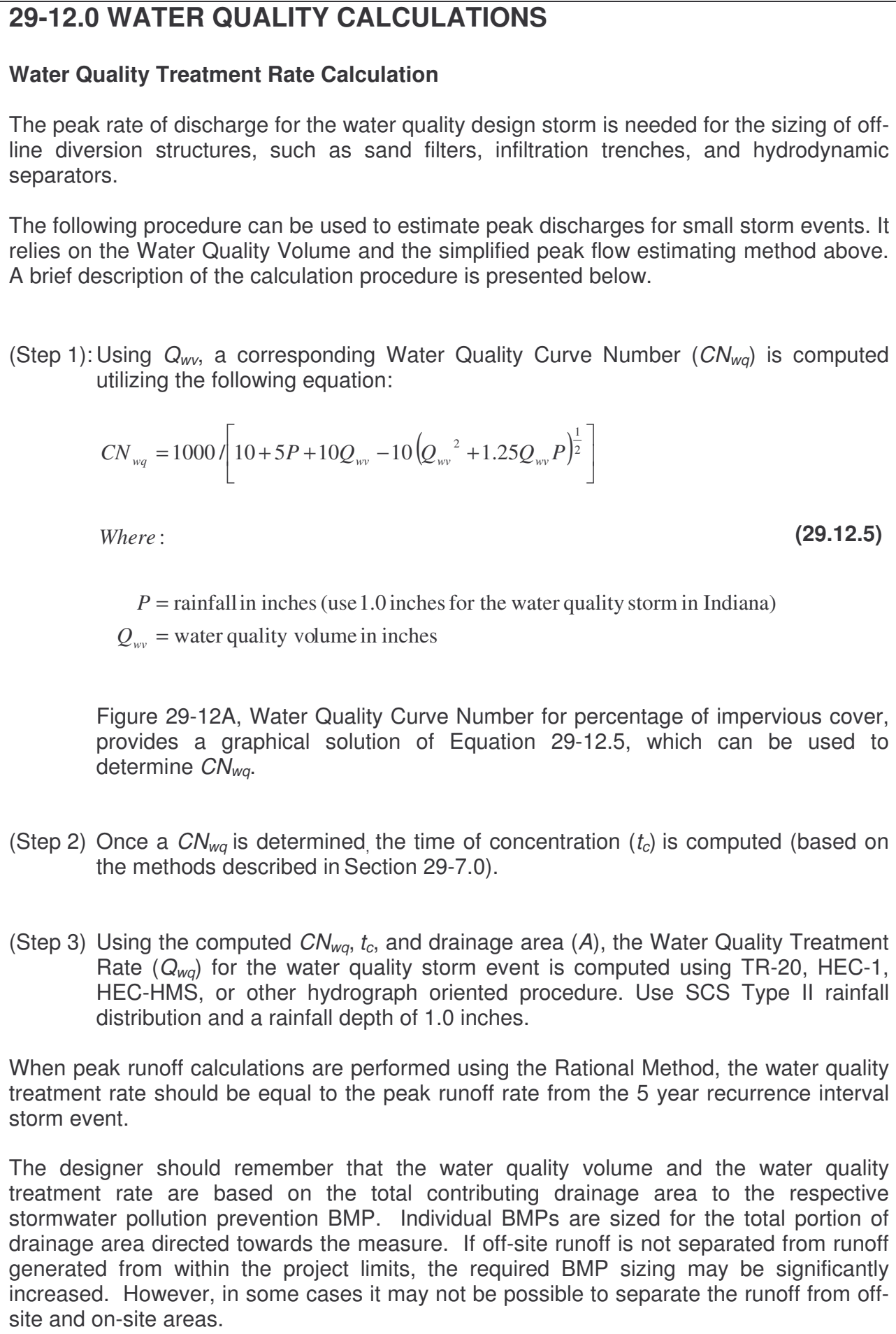 \\
\hline
\end{tabular}




\section{PART II - INDOT Standard Specifications}

No Recommended Revisions

\section{PART III - INDOT Standard Drawings}

No Recommended Revisions

\section{PART IV - INDOT Recurring Special Provisions}

No Recommended Revisions 


\section{Post-Construction Phase BMP Component - Native Seeding (Permanent)}

\section{PART I - INDOT Design Manuals}

No Recommended Revisions

\section{PART II - INDOT Standard Specifications}

\begin{tabular}{|c|c|}
\hline Document & INDOT Standard Specifications \\
\hline Reference Location & SECTION 600 - INCIDENTAL CONSTRUCTION \\
\hline Reference Location & SECTION 621 - SEEDING AND SODDING \\
\hline Reference Location & 621.06 Seed Mixtures \\
\hline Proposed Revision & $\begin{array}{l}\text { - In some cases, specific seed mixtures are developed for the seeding of TRM. } \\
\text { However, the current INDOT Type D seed mixture may be acceptable for TRM } \\
\text { applications, particularly in ditch or channel situations. INDOT should review the } \\
\text { seed available seed mixtures for TRM applications. } \\
\text { - INDOT may want to consider the addition of a conservation seed mixture } \\
\text { (wildflowers or color mix) to its standard seed mixtures. } \\
\text { - INDOT should consider warm season versus cool season seed mixtures. They } \\
\text { may also want to review all seed mixtures for their location specific applicability } \\
\text { for upland versus lowland areas, sandy versus clayey soils, etc. } \\
\text { - INDOT should perform a review of all their seed mixtures and vegetation } \\
\text { recommendations to ensure that species known to be noxious or invasive in the } \\
\text { State of Indiana (such as crown vetch) are not recommended. } \\
\text { INDOT should develop a recommended wetlands seed mixture and add it to the } \\
\text { Standard Specifications as a potential seeding type. A performance specification } \\
\text { should also be included in this seeding requirement. }\end{array}$ \\
\hline
\end{tabular}

\section{PART III - INDOT Standard Drawings}

No Recommended Revisions

\section{PART IV - INDOT Recurring Special Provisions}

No Recommended Revisions 


\section{Post-Construction Phase BMP Component - Riprap}

\section{PART I - INDOT Design Manuals}

No Recommended Revisions

\section{PART II - INDOT Standard Specifications}

No Recommended Revisions

\section{PART III - INDOT Standard Drawings}

No Recommended Revisions

\section{PART IV - INDOT Recurring Special Provisions}

\begin{tabular}{|c|c|}
\hline Document & INDOT Recurring Special Provisions \\
\hline Reference Location & SECTION 600 Incidental Construction \\
\hline Reference Location & 621-X-XXX (NEW RECURRING SPECIAL PROVISION) \\
\hline Proposed Revision & $\begin{array}{l}\text { - Vegetation of Revetment Riprap } \\
\text { This special provision should be created by INDOT staff. Native tree vegetation } \\
\text { should be recommended in the form of live tree staking. This practice should only be } \\
\text { used in drainage channels if the reduced velocity caused by the vegetation has been } \\
\text { considered in the design. This special provision may be considered for use in areas } \\
\text { where riprap is proposed for toe protection or bank stabilization. }\end{array}$ \\
\hline
\end{tabular}




\section{Post-Construction Phase BMP Component - Storage Facility - Dry Pond}

\section{PART I - INDOT Design Manuals}

\begin{tabular}{|l|l|}
\hline Document & INDOT Design Manual \\
\hline Reference Chapter & Chapter 35 - Storage Facilities \\
\hline Reference Section & 35-4.05 Outlet Works \\
\hline Proposed Revision & $\begin{array}{l}\text { Add the following paragraph at the end of section 35-4.05: } \\
\text { Multiple stage outlet works are recommended for wet and dry ponds that will } \\
\text { be used as stormwater BMPs. Multiple stage outlets should generally take } \\
\text { the form of one or more low flow orifice outlets with a secondary high-flow } \\
\text { pipe. INDOT discourages the use of riser pipes. An emergency spillway is } \\
\text { also required. The orifice should be sized for the baseflow. Where baseflow } \\
\text { can not be determined, O.1 cubic feet per second per acre of contributing } \\
\text { drainage area may be used as a general guide. However, if the orifice size } \\
\text { required is calculated to be less than } 4 \text { inches in diameter, a single 4-inch } \\
\text { diameter orifice opening shall be installed. In no case shall the orifice } \\
\text { diameter be smaller than } 100 \mathrm{~mm} \text { (4 inch) without prior approval due to } \\
\text { maintenance concerns. }\end{array}$ \\
\hline
\end{tabular}




\begin{tabular}{|c|c|}
\hline Document & INDOT Design Manual \\
\hline Reference Chapter & Chapter 35 - Storage Facilities \\
\hline Reference Section & 35-4.06 NEW SECTION \\
\hline Proposed Revision & 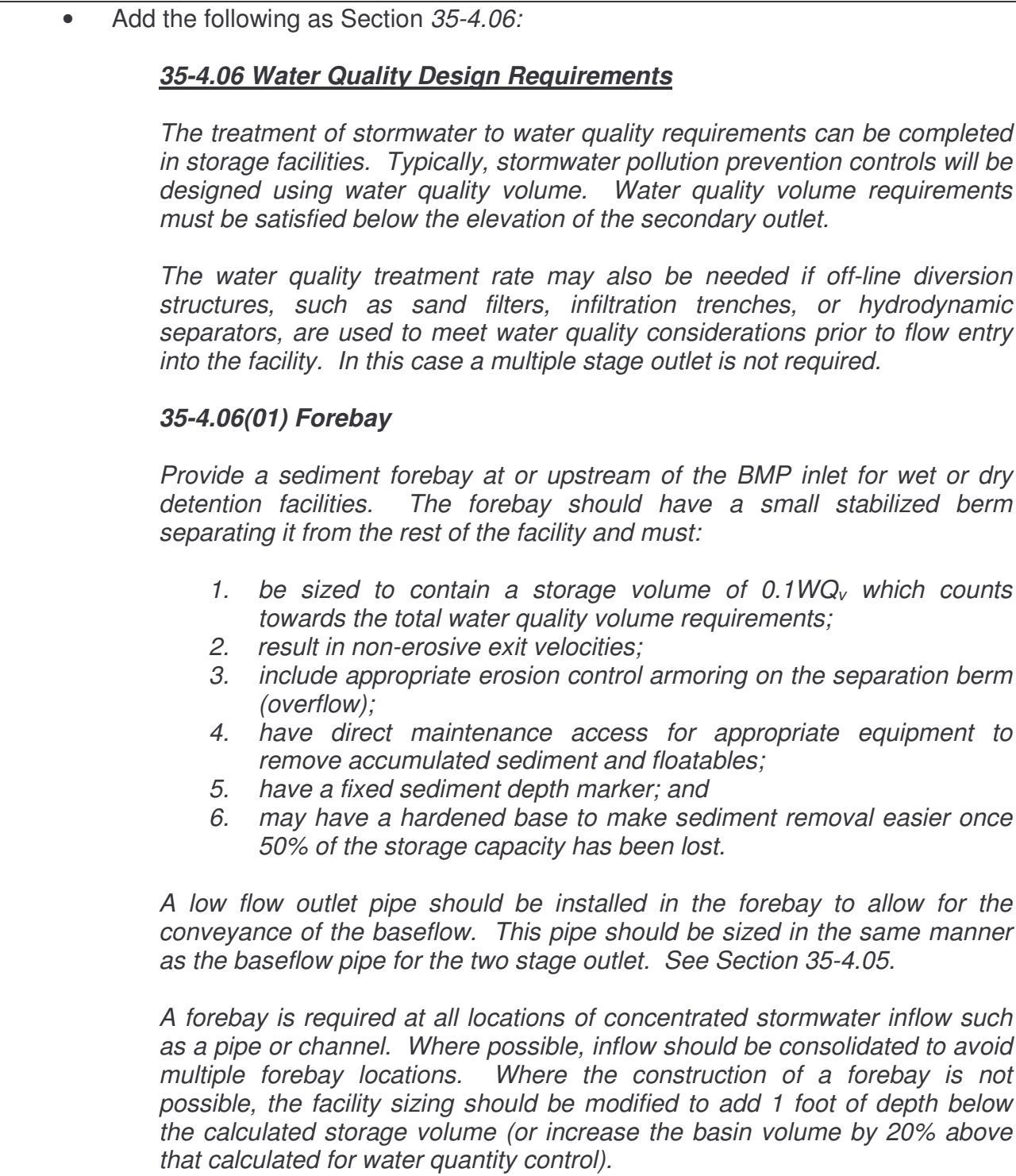 \\
\hline
\end{tabular}

\begin{tabular}{|c|c|}
\hline Document & INDOT Design Manual \\
\hline Reference Chapter & Chapter 35 - Storage Facilities \\
\hline Reference Section & 35-6.07 NEW SECTION \\
\hline & $\begin{array}{r}-\quad \text { Add the following as Section 35-6.07: } \\
\text { 35-6.07 Multiple Stage Outlets }\end{array}$ \\
\hline Proposed Revision & $\begin{array}{l}\text { When multiple stage outlet works are used, the elevation-discharge } \\
\text { relationships from the various outlet works may be added together provided } \\
\text { the head calculations were performed on the same datum. }\end{array}$ \\
\hline
\end{tabular}




\begin{tabular}{|c|c|}
\hline Document & INDOT Design Manual \\
\hline Reference Chapter & Chapter 35 - Storage Facilities \\
\hline Reference Section & 35-7.04, 35-7.05 NEW SECTION, Preliminary Basin Dimensions \\
\hline Proposed Revision & $\begin{array}{l}\text { - Renumber the existing Section 35-7.04 to 35-7.05. Add the following as Section } \\
\text { 35-7.04: } \\
\text { 35-7.04 Water Quality Volume Storage } \\
\text { An estimate of the water quality volume requirement for stormwater pollution } \\
\text { prevention can be calculated by following the procedure described in Section } \\
\text { 29-12.1. }\end{array}$ \\
\hline
\end{tabular}

\begin{tabular}{|c|c|}
\hline Document & INDOT Design Manual \\
\hline Reference Chapter & Chapter 35 - Storage Facilities \\
\hline Reference Section & 35-10.02 Design \\
\hline Proposed Revision & 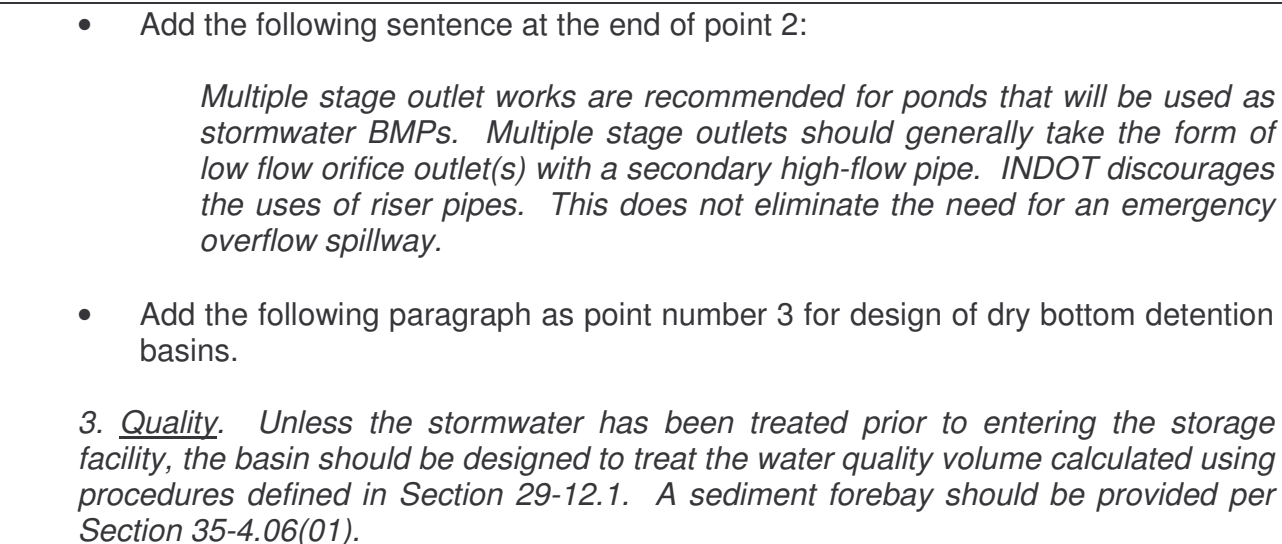 \\
\hline
\end{tabular}

\begin{tabular}{|c|c|}
\hline Document & INDOT Design Manual \\
\hline Reference Chapter & Chapter 35 - Storage Facilities \\
\hline Reference Section & 35-10.04 NEW SECTION \\
\hline Proposed Revision & $\begin{array}{l}\text { - Add the following section: } \\
\quad \text { 35-10.04 Illustration } \\
\text { See Figure 35-10A for an illustration of a typical dry water quality detention } \\
\text { pond. }\end{array}$ \\
\hline
\end{tabular}




\begin{tabular}{|c|c|}
\hline Document & INDOT Design Manual \\
\hline Reference Chapter & Chapter 35 - Storage Facilities \\
\hline Reference Section & 35-13.0 CONSTRUCTION AND MAINTENANCE CONSIDERATIONS \\
\hline Proposed Revision & $\begin{array}{l}\text { - Add the following items to the list of typical maintenance problems: } \\
\text { 9. sediment accumulation within the forebay and the facility } \\
\text { 10. erosion of the facility components. } \\
\text { - Add the following items to the second list of considerations: } \\
\text { 7. Sediment accumulation can lead to the loss of both design storage } \\
\text { volume and water quality volume. Loss of active storage volume may } \\
\text { result in higher release rates. Erosion of facility components, such as } \\
\text { the forebay berm, can contribute to sedimentation and undermine the } \\
\text { effectiveness of the forebay. }\end{array}$ \\
\hline
\end{tabular}




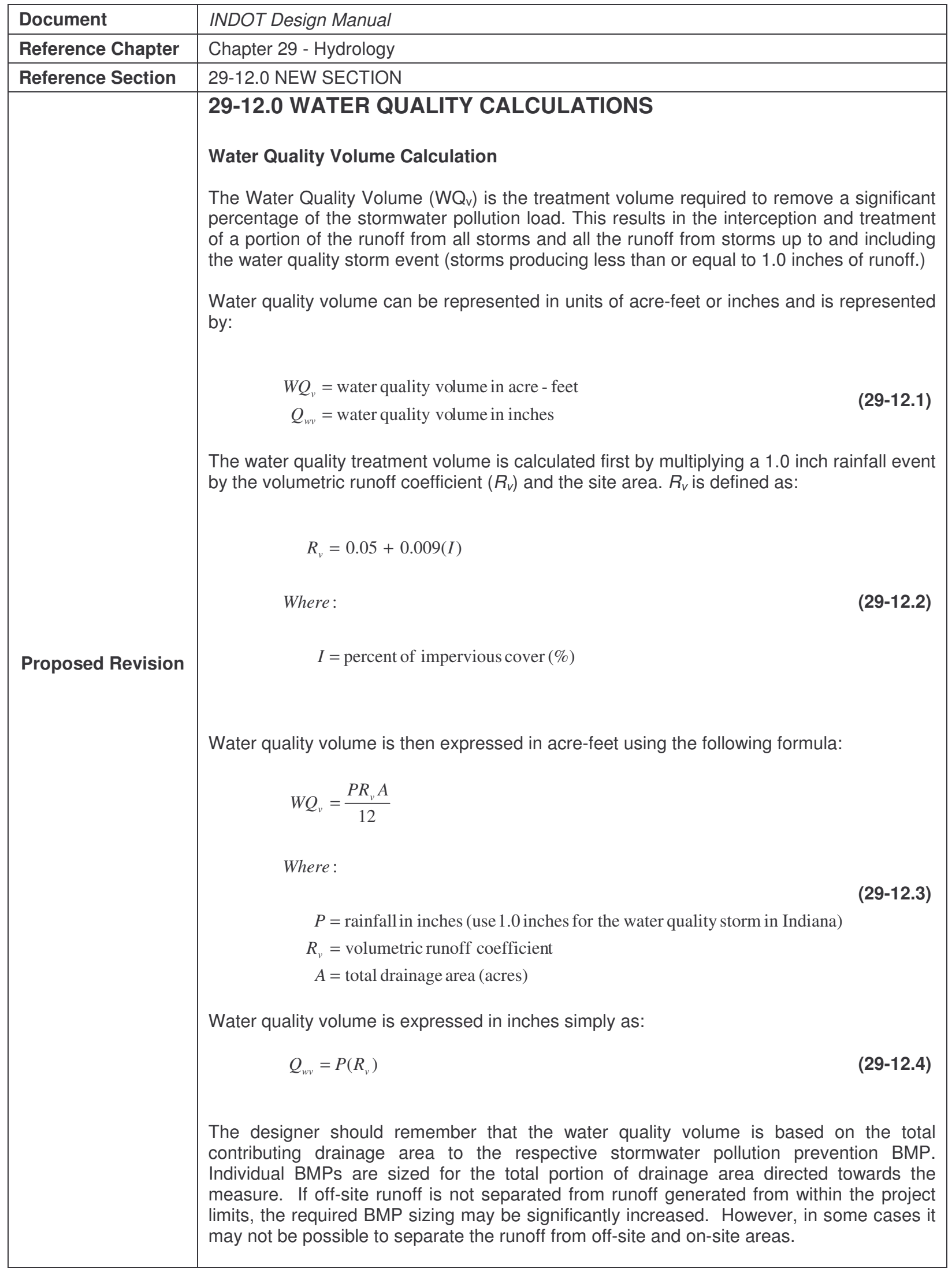




\section{PART II - INDOT Standard Specifications}

\begin{tabular}{|l|l|}
\hline Document & INDOT Standard Specifications \\
\hline Reference Location & SECTION 200 - EARTHWORK \\
\hline Reference Location & SECTION 205-TEMPORARY EROSION AND SEDIMENT CONTROL \\
\hline Reference Location & 205.03 Control Measures \\
\hline Proposed Revision & $\begin{array}{c}\text { Add the following at the end of section 205.03(m) Detention Ponds: } \\
\text { If detention facilities are used as temporary sediment traps during } \\
\text { construction, accumulated sediment shall be removed prior to the final } \\
\text { acceptance of the project. }\end{array}$ \\
\hline
\end{tabular}

\section{PART III - INDOT Standard Drawings}

No Recommended Revisions

\section{PART IV - INDOT Recurring Special Provisions}

No Recommended Revisions 


\section{Post-Construction Phase BMP Component - Storage Facility - Extended Detention Pond}

\section{PART I - INDOT Design Manuals}

\begin{tabular}{|l|l|}
\hline Document & INDOT Design Manual \\
\hline Reference Chapter & Chapter 35 - Storage Facilities \\
\hline Reference Section & 35-4.05 Outlet Works \\
\hline Proposed Revision & $\begin{array}{c}\text { Add the following paragraph at the end of section 35-4.05: } \\
\text { Multiple stage outlet works are recommended for wet and dry ponds that will } \\
\text { be used as stormwater BMPs. Multiple stage outlets should generally take } \\
\text { the form of one or more low flow orifice outlets with a secondary high-flow } \\
\text { pipe. INDOT discourages the use of riser pipes. An emergency spillway is } \\
\text { also required. The orifice should be sized for the baseflow. Where baseflow } \\
\text { can not be determined, O.1 cubic feet per second per acre of contributing } \\
\text { drainage area may be used as a general guide. However, if the orifice size } \\
\text { required is calculated to be less than } 4 \text { inches in diameter, a single 4-inch } \\
\text { diameter orifice opening shall be installed. In no case shall the orifice } \\
\text { diameter be smaller than } 100 \mathrm{~mm} \text { (4 inch) without prior approval due to } \\
\text { maintenance concerns. }\end{array}$ \\
\hline
\end{tabular}




\begin{tabular}{|c|c|}
\hline Document & INDOT Design Manual \\
\hline Reference Chapter & Chapter 35 - Storage Facilities \\
\hline Reference Section & 35-4.06 NEW SECTION \\
\hline Proposed Revision & 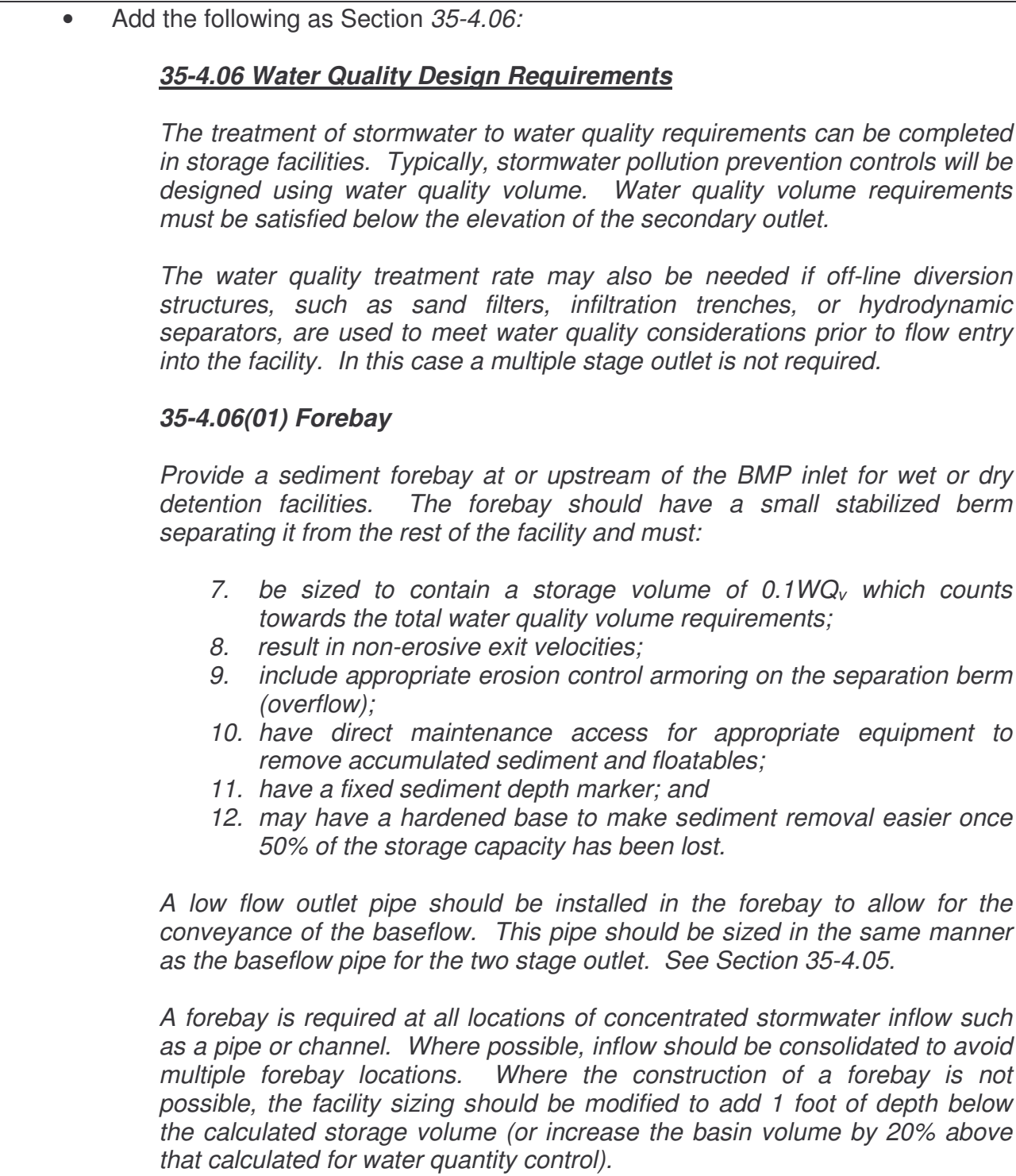 \\
\hline
\end{tabular}

\begin{tabular}{|l|c|}
\hline Document & INDOT Design Manual \\
\hline Reference Chapter & Chapter 35 - Storage Facilities \\
\hline Reference Section & $\begin{array}{l}35-6.07 \text { NEW SECTION } \\
\text { Proposed Revision }\end{array}$ \\
\hline $\begin{array}{l}\text { 35-6.07 Multiple Stage Outlets } \\
\text { When multiple stage outlet works are used, the elevation-discharge } \\
\text { relationships from the various outlet works may be added together provided } \\
\text { the head calculations were performed on the same datum. }\end{array}$ \\
\hline
\end{tabular}




\begin{tabular}{|c|c|}
\hline Document & INDOT Design Manual \\
\hline Reference Chapter & Chapter 35 - Storage Facilities \\
\hline Reference Section & 35-7.04, 35-7.05 NEW SECTION, Preliminary Basin Dimensions \\
\hline Proposed Revision & $\begin{array}{l}\text { - Renumber the existing Section 35-7.04 to 35-7.05. Add the following as Section } \\
\text { 35-7.04: } \\
\text { 35-7.04 Water Quality Volume Storage } \\
\text { An estimate of the water quality volume requirement for stormwater pollution } \\
\text { prevention can be calculated by following the procedure described in Section } \\
\text { 29-12.1. }\end{array}$ \\
\hline
\end{tabular}

\begin{tabular}{|l|l|}
\hline Document & INDOT Design Manual \\
\hline Reference Chapter & Chapter 35 - Storage Facilities \\
\hline Reference Section & 35-11.02 Design \\
\hline & $\begin{array}{c}\text { Add the following sentence at the end of point 2: } \\
\text { Multiple stage outlet works are recommended for ponds that will be used as } \\
\text { stormwater BMPs. Multiple stage outlets should generally take the form of a } \\
\text { low flow orifice outlet with a secondary high-flow pipe. INDOT discourages } \\
\text { the use of risers. This does not eliminate the need for an emergency } \\
\text { spillway. }\end{array}$ \\
$\begin{array}{l}\text { Add the following paragraph as point number } 3 \text { for design of wet bottom detention } \\
\text { basins. }\end{array}$ \\
$\begin{array}{l}\text { 3. Quality. Unless the stormwater has been treated prior to entering the } \\
\text { storage facility, the basin should be designed to treat the water quality } \\
\text { volume calculated using procedures defined in Section 29-12.1. A sediment } \\
\text { forebay should be provided per Section 35-4.06(01). }\end{array}$ \\
\hline
\end{tabular}

\begin{tabular}{|l|l|}
\hline Document & INDOT Design Manual \\
\hline Reference Chapter & Chapter 35 - Storage Facilities \\
\hline Reference Section & $\begin{array}{c}\text { 35-11.03 Other Considerations } \\
\text { Proposed Revision } \\
\text { maintenance: }\end{array}$ \\
$\begin{array}{l}\text { The facility should also be inspected at least annually during dry weather to } \\
\text { monitor sediment accumulation within the forebay, inspect the forebay and } \\
\text { outlet works for damage, and to identify areas in need of revegetation. } \\
\text { Damaged or unvegetated areas should be repaired. Litter and sediment } \\
\text { removal should be coordinated with the mowing schedule and be performed } \\
\text { as needed. }\end{array}$ \\
\hline
\end{tabular}

\begin{tabular}{|l|l|}
\hline Document & INDOT Design Manual \\
\hline Reference Chapter & Chapter 35-Storage Facilities \\
\hline Reference Section & $35-11.04$ Illustration \\
\hline Proposed Revision & $\begin{array}{l}\text { Figure } 35-11 A \text { should be updated to show a plan view and cross section of a } \\
\text { typical wet water quality detention pond showing water quality volume limits, } \\
\text { sediment forebay, and other pertinent components. }\end{array}$ \\
\hline
\end{tabular}




\begin{tabular}{|c|c|}
\hline Document & INDOT Design Manual \\
\hline Reference Chapter & Chapter 35 - Storage Facilities \\
\hline Reference Section & 35-13.0 CONSTRUCTION AND MAINTENANCE CONSIDERATIONS \\
\hline Proposed Revision & $\begin{array}{l}\text { - Add the following items to the list of typical maintenance problems: } \\
\text { 9. sediment accumulation within the forebay and the facility } \\
\text { 10. erosion of the facility components. } \\
\text { - Add the following items to the second list of considerations: } \\
\text { 8. Sediment accumulation can lead to the loss of both design storage } \\
\text { volume and water quality volume. Loss of active storage volume may } \\
\text { result in higher release rates. Erosion of facility components, such as } \\
\text { the forebay berm, can contribute to sedimentation and undermine the } \\
\text { effectiveness of the forebay. }\end{array}$ \\
\hline
\end{tabular}




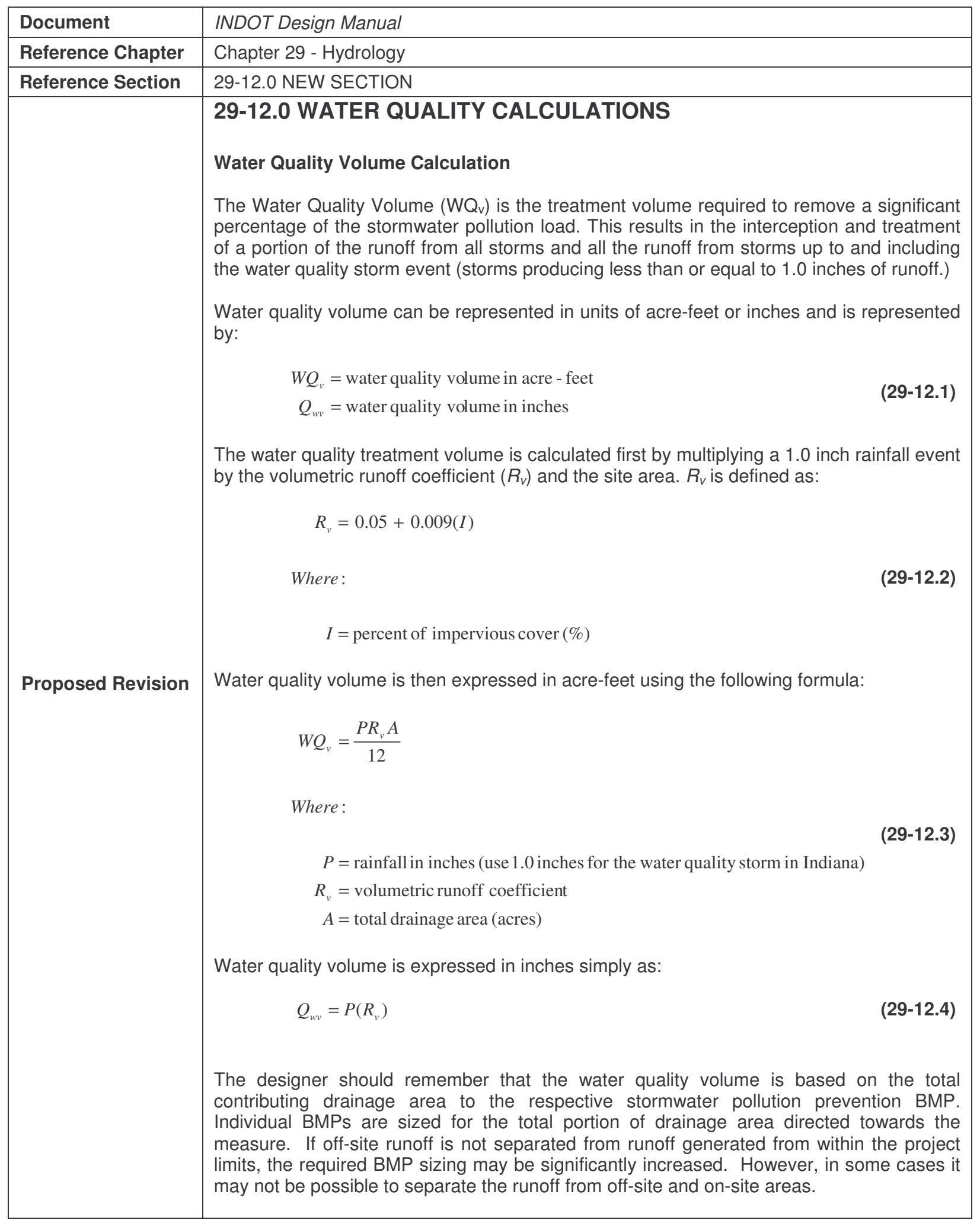




\section{PART II - INDOT Standard Specifications}

\begin{tabular}{|l|l|}
\hline Document & INDOT Standard Specifications \\
\hline Reference Location & SECTION 200 - EARTHWORK \\
\hline Reference Location & SECTION 205 - TEMPORARY EROSION AND SEDIMENT CONTROL \\
\hline Reference Location & 205.03 Control Measures \\
\hline Proposed Revision & $\begin{array}{c}\text { Add the following at the end of section 205.03(m) Detention Ponds: } \\
\text { If detention facilities are used as temporary sediment traps during } \\
\text { construction, accumulated sediment shall be removed prior to the final } \\
\text { acceptance of the project. }\end{array}$ \\
\hline
\end{tabular}

\section{PART III - INDOT Standard Drawings}

No Recommended Revisions

\section{PART IV - INDOT Recurring Special Provisions}

No Recommended Revisions 


\section{Post-Construction Phase BMP Component - Storage Facility - Wet Pond}

\section{PART I - INDOT Design Manuals}

\begin{tabular}{|l|l|}
\hline Document & INDOT Design Manual \\
\hline Reference Chapter & Chapter 35 - Storage Facilities \\
\hline Reference Section & 35-4.05 Outlet Works \\
\hline Proposed Revision & $\begin{array}{l}\text { Add the following paragraph at the end of section 35-4.05: } \\
\text { Multiple stage outlet works are recommended for wet and dry ponds that will } \\
\text { be used as stormwater BMPs. Multiple stage outlets should generally take } \\
\text { the form of one or more low flow orifice outlets with a secondary high-flow } \\
\text { pipe. INDOT discourages the use of riser pipes. An emergency spillway is } \\
\text { also required. The orifice should be sized for the baseflow. Where baseflow } \\
\text { can not be determined, O.1 cubic feet per second per acre of contributing } \\
\text { drainage area may be used as a general guide. However, if the orifice size } \\
\text { required is calculated to be less than } 4 \text { inches in diameter, a single 4-inch } \\
\text { diameter orifice opening shall be installed. In no case shall the orifice } \\
\text { diameter be smaller than } 100 \mathrm{~mm} \text { (4 inch) without prior approval due to } \\
\text { maintenance concerns. }\end{array}$ \\
\hline
\end{tabular}




\begin{tabular}{|c|c|}
\hline Document & INDOT Design Manual \\
\hline Reference Chapter & Chapter 35 - Storage Facilities \\
\hline Reference Section & 35-4.06 NEW SECTION \\
\hline Proposed Revision & 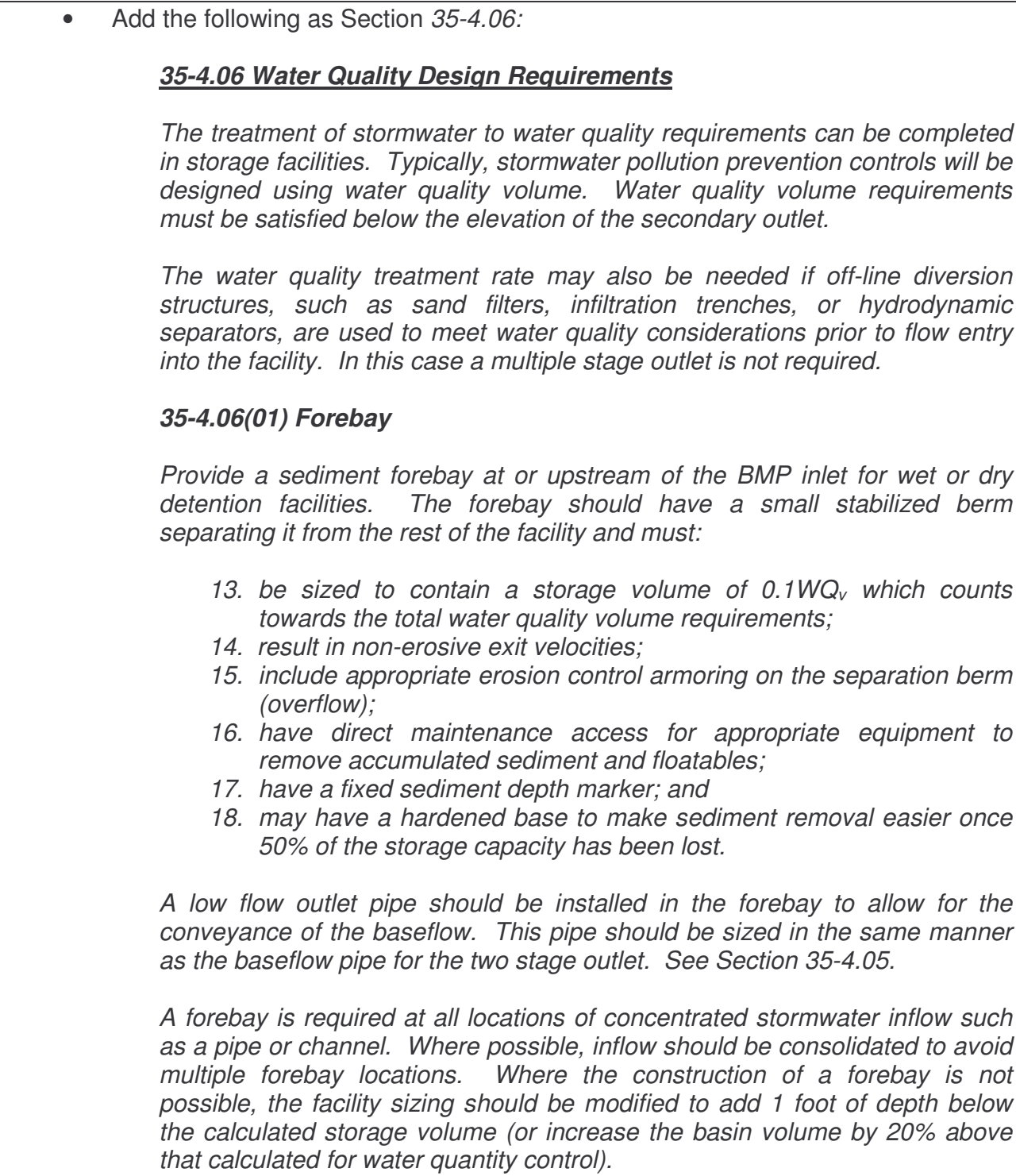 \\
\hline
\end{tabular}

\begin{tabular}{|l|c|}
\hline Document & INDOT Design Manual \\
\hline Reference Chapter & Chapter 35 - Storage Facilities \\
\hline Reference Section & $\begin{array}{l}35-6.07 \text { NEW SECTION } \\
\text { Proposed Revision }\end{array}$ \\
\hline $\begin{array}{l}\text { 35-6.07 Multiple Stage Outlets } \\
\text { When multiple stage outlet works are used, the elevation-discharge } \\
\text { relationships from the various outlet works may be added together provided } \\
\text { the head calculations were performed on the same datum. }\end{array}$ \\
\hline
\end{tabular}




\begin{tabular}{|c|c|}
\hline Document & INDOT Design Manual \\
\hline Reference Chapter & Chapter 35 - Storage Facilities \\
\hline Reference Section & 35-7.04, 35-7.05 NEW SECTION, Preliminary Basin Dimensions \\
\hline Proposed Revision & $\begin{array}{l}\text { - Renumber the existing Section 35-7.04 to 35-7.05. Add the following as Section } \\
\text { 35-7.04: } \\
\text { 35-7.04 Water Quality Volume Storage } \\
\text { An estimate of the water quality volume requirement for stormwater pollution } \\
\text { prevention can be calculated by following the procedure described in Section } \\
\text { 29-12.1. }\end{array}$ \\
\hline
\end{tabular}

\begin{tabular}{|c|c|}
\hline Document & INDOT Design Manual \\
\hline Reference Chapter & Chapter 35 - Storage Facilities \\
\hline Reference Section & 35-11.02 Design \\
\hline Proposed Revision & $\begin{array}{l}\text { - Add the following sentence at the end of point 2: } \\
\text { Multiple stage outlet works are recommended for ponds that will be used as } \\
\text { stormwater BMPs. Multiple stage outlets should generally take the form of a } \\
\text { low flow orifice outlet with a secondary high-flow pipe. INDOT discourages } \\
\text { the use of risers. This does not eliminate the need for an emergency } \\
\text { spillway. } \\
\text { - Add the following paragraph as point number } 3 \text { for design of wet bottom detention } \\
\text { basins. } \\
\text { 3. Quality. Unless the stormwater has been treated prior to entering the } \\
\text { storage facility, the basin should be designed to treat the water quality } \\
\text { volume calculated using procedures defined in Section 29-12.1. A sediment } \\
\text { forebay should be provided per Section 35-4.06(01). }\end{array}$ \\
\hline
\end{tabular}

\begin{tabular}{|l|l|}
\hline Document & INDOT Design Manual \\
\hline Reference Chapter & Chapter 35 - Storage Facilities \\
\hline Reference Section & $\begin{array}{c}\text { 35-11.03 Other Considerations } \\
\text { maintenance: }\end{array}$ \\
Proposed Revision & $\begin{array}{l}\text { The facility should also be inspected at least annually during dry weather to } \\
\text { monitor sediment accumulation within the forebay, inspect the forebay and } \\
\text { outlet works for damage, and to identify areas in need of revegetation. } \\
\text { Damaged or unvegetated areas should be repaired. Litter and sediment } \\
\text { removal should be coordinated with the mowing schedule and be performed } \\
\text { as needed. }\end{array}$ \\
\hline
\end{tabular}

\begin{tabular}{|l|l|}
\hline Document & INDOT Design Manual \\
\hline Reference Chapter & Chapter 35- Storage Facilities \\
\hline Reference Section & $35-11.04$ Illustration \\
\hline Proposed Revision & $\begin{array}{l}\text { Figure 35-11A should be updated to show a plan view and cross section of a typical wet } \\
\text { water quality detention pond showing water quality volume limits, sediment forebay, and } \\
\text { other pertinent components. }\end{array}$ \\
\hline
\end{tabular}




\begin{tabular}{|c|c|}
\hline Document & INDOT Design Manual \\
\hline Reference Chapter & Chapter 35 - Storage Facilities \\
\hline Reference Section & 35-13.0 CONSTRUCTION AND MAINTENANCE CONSIDERATIONS \\
\hline Proposed Revision & $\begin{array}{l}\text { - Add the following items to the list of typical maintenance problems: } \\
\text { 9. sediment accumulation within the forebay and the facility } \\
\text { 10. erosion of the facility components. } \\
\text { - Add the following items to the second list of considerations: } \\
\text { 9. Sediment accumulation can lead to the loss of both design storage } \\
\text { volume and water quality volume. Loss of active storage volume may } \\
\text { result in higher release rates. Erosion of facility components, such as } \\
\text { the forebay berm, can contribute to sedimentation and undermine the } \\
\text { effectiveness of the forebay. }\end{array}$ \\
\hline
\end{tabular}




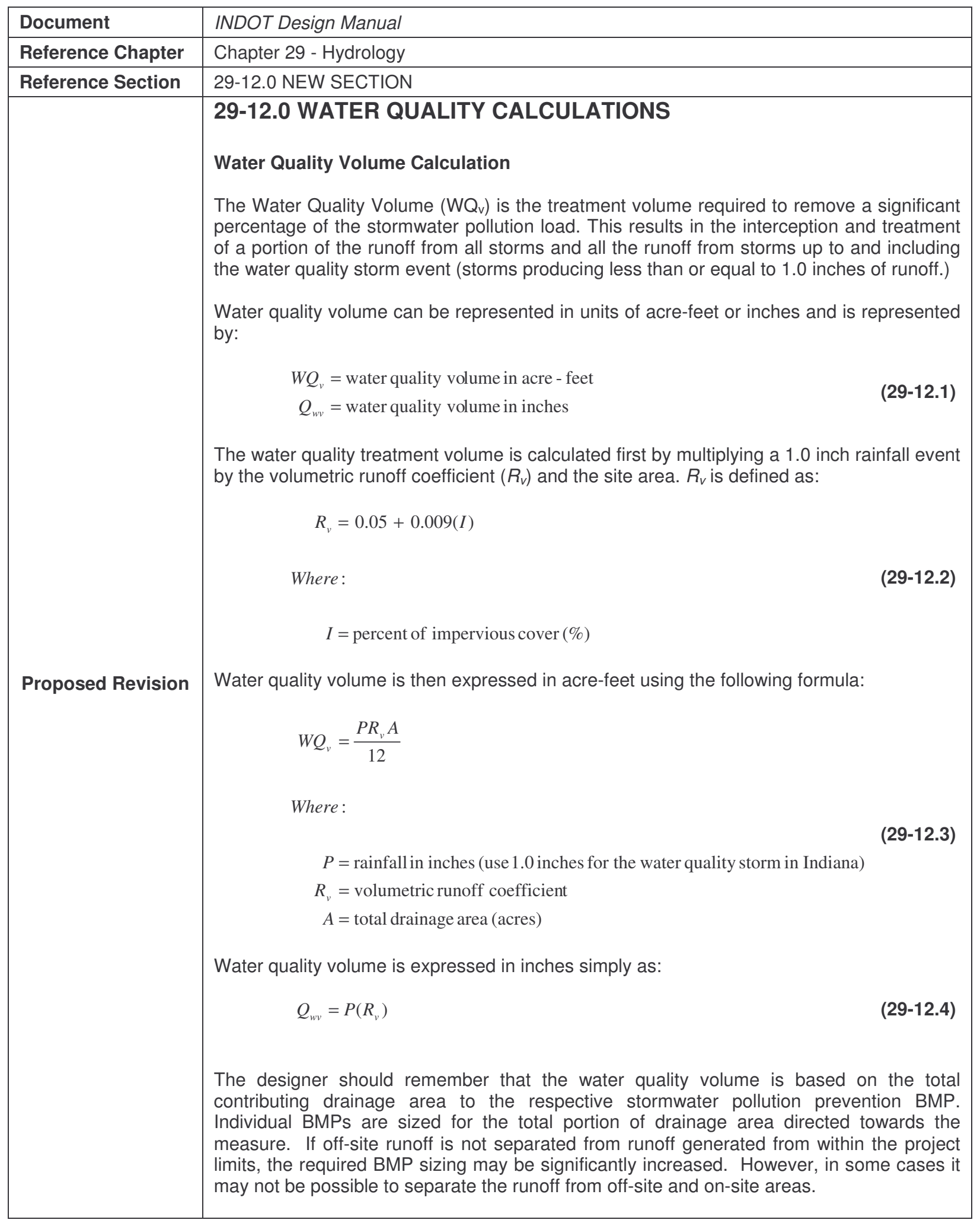




\section{PART II - INDOT Standard Specifications}

\begin{tabular}{|l|l|}
\hline Document & INDOT Standard Specifications \\
\hline Reference Location & SECTION 200 - EARTHWORK \\
\hline Reference Location & SECTION 205 - TEMPORARY EROSION AND SEDIMENT CONTROL \\
\hline Reference Location & 205.03 Control Measures \\
\hline Proposed Revision & $\begin{array}{c}\text { Add the following at the end of section 205.03(m) Detention Ponds: } \\
\text { If detention facilities are used as temporary sediment traps during } \\
\text { construction, accumulated sediment shall be removed prior to the final } \\
\text { acceptance of the project. }\end{array}$ \\
\hline
\end{tabular}

\section{PART III - INDOT Standard Drawings}

No Recommended Revisions

\section{PART IV - INDOT Recurring Special Provisions}

No Recommended Revisions 


\section{Post-Construction Phase BMP Component - Stormwater Wetland (Native Vegetation)}

\section{PART I - INDOT Design Manuals}

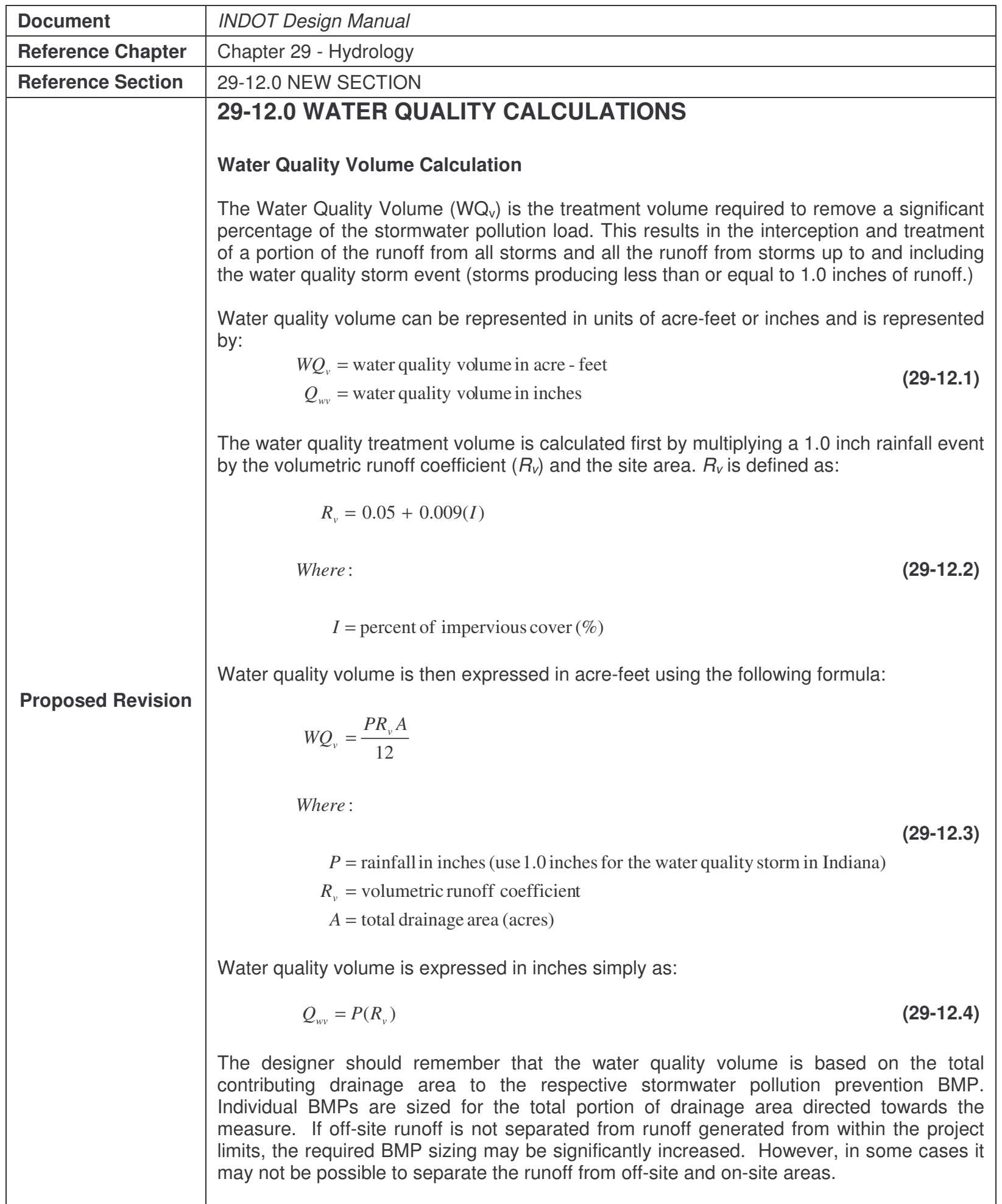




\section{PART II - INDOT Standard Specifications}

\begin{tabular}{|l|c|}
\hline Document & INDOT Standard Specifications \\
\hline Reference Location & SECTION 600 - INCIDENTAL CONSTRUCTION \\
\hline Reference Location & SECTION 603 - FENCES \\
\hline Reference Location & \begin{tabular}{l} 
S03.02 Materials \\
\hline Proposed Revision
\end{tabular} \\
& $\begin{array}{c}\text { Add the following items alphabetically to the list of materials. Add the appropriate } \\
\text { section reference number: }\end{array}$ \\
& Plastic Vegetation Protection Fence \\
& Twine for Vegetation Protection Fence \\
\hline
\end{tabular}

\begin{tabular}{|c|c|}
\hline Document & INDOT Standard Specifications \\
\hline Reference Location & SECTION 600 - INCIDENTAL CONSTRUCTION \\
\hline Reference Location & SECTION 603 - FENCES \\
\hline Reference Location & 603.07 Vegetation Protection Fence (NEW SECTION) \\
\hline Proposed Revision & $\begin{array}{l}\text { - Change Section } 603.07 \text { Method of Measurement to } 603.08 \text { Method of } \\
\text { Measurement. } \\
\text { - Add the following text as Section 603.07: } \\
603.07 \text { Vegetation Protection Fence. Surround wetland plug plantings or } \\
\text { other vegetation that is susceptible to damage from occupation or } \\
\text { consumption by wildlife, with vegetation protection fence. Standard farm field } \\
\text { fence posts should be used to support the plastic fence fabric. Apply tension } \\
\text { to the field fabric so that no sagging occurs in between posts. Place fence } \\
\text { posts no more than } 8 \text { feet apart. Drive post to a sufficient depth to develop } \\
\text { strength. Stretch twine in between fence posts over the enclosed area to } \\
\text { form a grid to discourage wildlife from landing in the interior area. Install the } \\
\text { twine grid to create a minimum number of } 4 \text { foot by } 4 \text { foot openings. } \\
\text { Additional line posts may be required for the grid establishment. } \\
\text { The vegetation protection fence should be removed once the wetland } \\
\text { planting performance specifications have been satisfied. All fence posts, } \\
\text { twine, and plastic fence fabric material shall be removed. }\end{array}$ \\
\hline
\end{tabular}

\begin{tabular}{|c|c|}
\hline Document & INDOT Standard Specifications \\
\hline Reference Location & SECTION 600 - INCIDENTAL CONSTRUCTION \\
\hline Reference Location & SECTION 603 - FENCES \\
\hline Reference Location & 603.09 Basis of Payment (Renumbered) \\
\hline Proposed Revision & $\begin{array}{l}\text { - Change Section } 603.08 \text { Basis of Payment to } 603.09 \text { Basis of Payment } \\
\text { - Add the following items to the list of pay items: } \\
\text { Fence, Vegetation Protection ..............................m (LFT) } \\
\text { - Add the following exception under the list of pay items: } \\
\text { The cost of vegetation protection fence installation shall include fence posts, } \\
\text { twine, and all incidentals required for the fence installation and maintenance. }\end{array}$ \\
\hline
\end{tabular}




\begin{tabular}{|l|l|}
\hline Document & INDOT Standard Specifications \\
\hline Reference Location & SECTION 600 - INCIDENTAL CONSTRUCTION \\
\hline Reference Location & SECTION 622 - PLANTING TREES, SHRUBS, AND VINES \\
\hline Reference Location & \begin{tabular}{c} 
622.02 Materials, General Comments \\
\hline Proposed Revision
\end{tabular} \\
$\begin{array}{c}\text { Add the following to the list of materials and the appropriate section reference: } \\
\text { Vegetation Protection Fence }\end{array}$ \\
$\begin{array}{c}\text { Add a pay item for Wetland Plugs. The suggest method of measurement and } \\
\text { basis of payment unit is per EACH plug. It is recommended that payment for } \\
\text { fence removal shall be incidental to payment for the wetland plugs. }\end{array}$ \\
\hline
\end{tabular}

\begin{tabular}{|c|c|c|}
\hline Document & \multicolumn{2}{|l|}{ INDOT Standard Specifications } \\
\hline Reference Location & \multicolumn{2}{|l|}{ SECTION 900 - MATERIALS DETAILS } \\
\hline Reference Location & \multicolumn{2}{|c|}{ SECTION 914 - ROADSIDE DEVELOPMENT MATERIALS } \\
\hline Reference Location & \multicolumn{2}{|l|}{ 914.09 Miscellaneous Materials } \\
\hline \multirow{6}{*}{ Proposed Revision } & \multicolumn{2}{|c|}{$\begin{array}{l}\text { h. Vegetation Protection Fence. The fence netting for vegetation protection } \\
\text { pods may be constructed on high visibility orange or natural green durable, } \\
\text { UV stabilized high-density polyethylene (HDPE). Vegetation protection fence } \\
\text { is not a structural fence system. Physical properties guidelines of the } \\
\text { vegetation protection fence are listed below. Actual properties will vary by } \\
\text { fabric supplier. }\end{array}$} \\
\hline & Physical Property & Typical Value \\
\hline & Mesh Size & $88 \mathrm{~mm} \times 38 \mathrm{~mm}(3.5 \mathrm{in} \times 1.5 \mathrm{in})$ \\
\hline & Roll Dimensions (length $x$ width) & $30 \mathrm{~m} \times 1.4 \mathrm{~m}(100 \mathrm{ft} \times 4 \mathrm{ft})$ \\
\hline & Roll Area & $37 \mathrm{~m}^{2}\left(400 \mathrm{ft}^{2}\right)$ \\
\hline & Estimated Roll Weight & $6.7 \mathrm{~kg}(14.7 \mathrm{lbs})$ \\
\hline
\end{tabular}

\section{PART III - INDOT Standard Drawings}

No Recommended Revisions

\section{PART IV - INDOT Recurring Special Provisions}

No Recommended Revisions 


\section{Post-Construction Phase BMP Component - Turf Reinforcement Mat (TRM)}

\section{PART I - INDOT Design Manuals}

\begin{tabular}{|l|c|}
\hline Document & INDOT Design Manual \\
\hline Reference Chapter & Chapter 30 - Channels \\
\hline Reference Section & 30-3.03(02) Channel Linings \\
\hline Proposed Revision & Add the following definition: \\
& $\begin{array}{l}\text { Turf Reinforcement Mat Lined Channels (TRM) TRM channel linings are } \\
\text { three dimensional reinforcement matrices that provide sufficient thickness, } \\
\text { strength and void space to permit soil filling and/or retention and the } \\
\text { development of vegetation within the matrix. TRMs are composed of UV } \\
\text { stabilized, non-degradable, synthetic fibers or nettings. The medium of soil, } \\
\text { vegetation, and fiber is designed for permanent and critical hydraulic } \\
\text { applications where design discharges exert velocities and shear stresses that } \\
\text { exceed the limits of mature, natural vegetation. TRMs should be designed } \\
\text { based on allowable shear stress of the channel lining. }\end{array}$ \\
\hline
\end{tabular}

\begin{tabular}{|c|c|}
\hline Document & INDOT Design Manual \\
\hline Reference Chapter & Chapter 30 - Channels \\
\hline Reference Section & 30-3.03(02) Channel Linings \\
\hline Proposed Revision & $\begin{array}{l}\text { - The use of TRMs has increased in the past several years as communities have } \\
\text { become more aware of water quality concerns. The primary benefit of TRMs is } \\
\text { they allow for infiltration and they can filter runoff from smaller rainfall events once } \\
\text { vegetated. The other channel linings listed in Section 3.03(02) state an } \\
\text { approximate design slope. However, it is recommended that the calculated } \\
\text { maximum shear stress be used to design TRMs and other channel linings. } \\
\text { Related to TRMs and other channel linings, the shear stress can be calculated } \\
\text { using: } \\
\qquad \begin{aligned} \tau & =\gamma_{\text {water }} y S_{o} \\
& \text { Where } \\
\tau & =\text { shear stress } \\
\gamma_{\text {water }} & =\text { unit weight of water }\left(62.4 \mathrm{lb} / \mathrm{ft}^{3}\right) \\
y & =\text { maximum design flow detph } \\
S_{o} & =\text { channel slope }\end{aligned}\end{array}$ \\
\hline
\end{tabular}

\begin{tabular}{|l|l|}
\hline Document & INDOT Design Manual \\
\hline Reference Chapter & Chapter 30 - Channels \\
\hline Reference Section & Figure 30-6C \\
\hline Proposed Revision & $\bullet \quad$ Add the permissible shear stress value for TRMs. \\
\hline
\end{tabular}




\section{PART II - INDOT Standard Specifications}

\begin{tabular}{|c|c|}
\hline Document & INDOT Standard Specifications \\
\hline Reference Location & SECTION 600 - INCIDENTAL CONSTRUCTION \\
\hline Reference Location & SECTION 621 - SEEDING AND SODDING \\
\hline Reference Location & 621.05 Applying Fertilizer, Seed, and Mulch \\
\hline Proposed Revision & 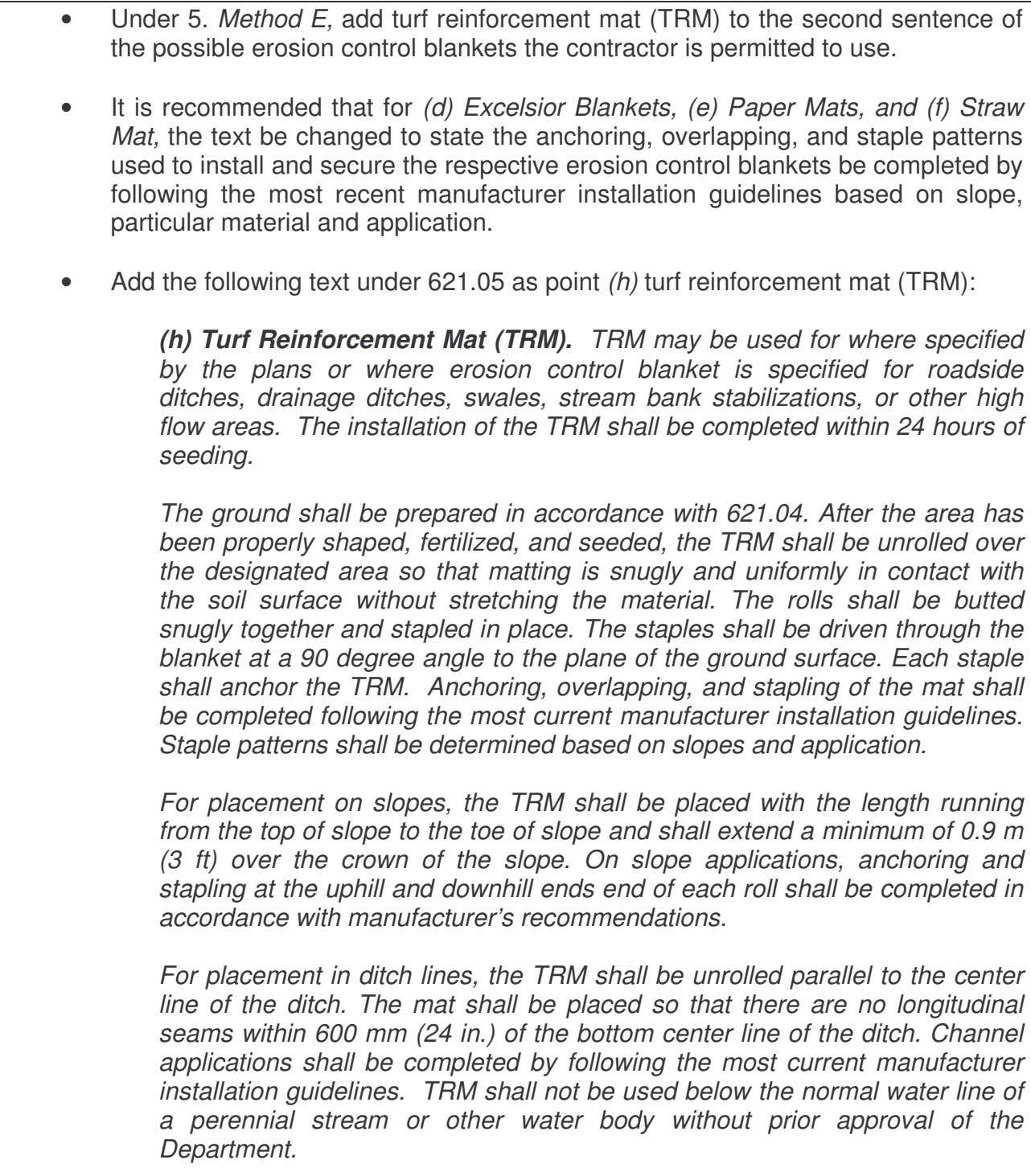 \\
\hline
\end{tabular}




\begin{tabular}{|c|c|}
\hline Document & INDOT Standard Specifications \\
\hline Reference Location & SECTION 900 - MATERIALS DETAILS \\
\hline Reference Location & SECTION 914 - ROADSIDE DEVELOPMENT MATERIALS \\
\hline Reference Location & 914.10 Turf Reinforcement Mat (TRM) \\
\hline Proposed Revision & 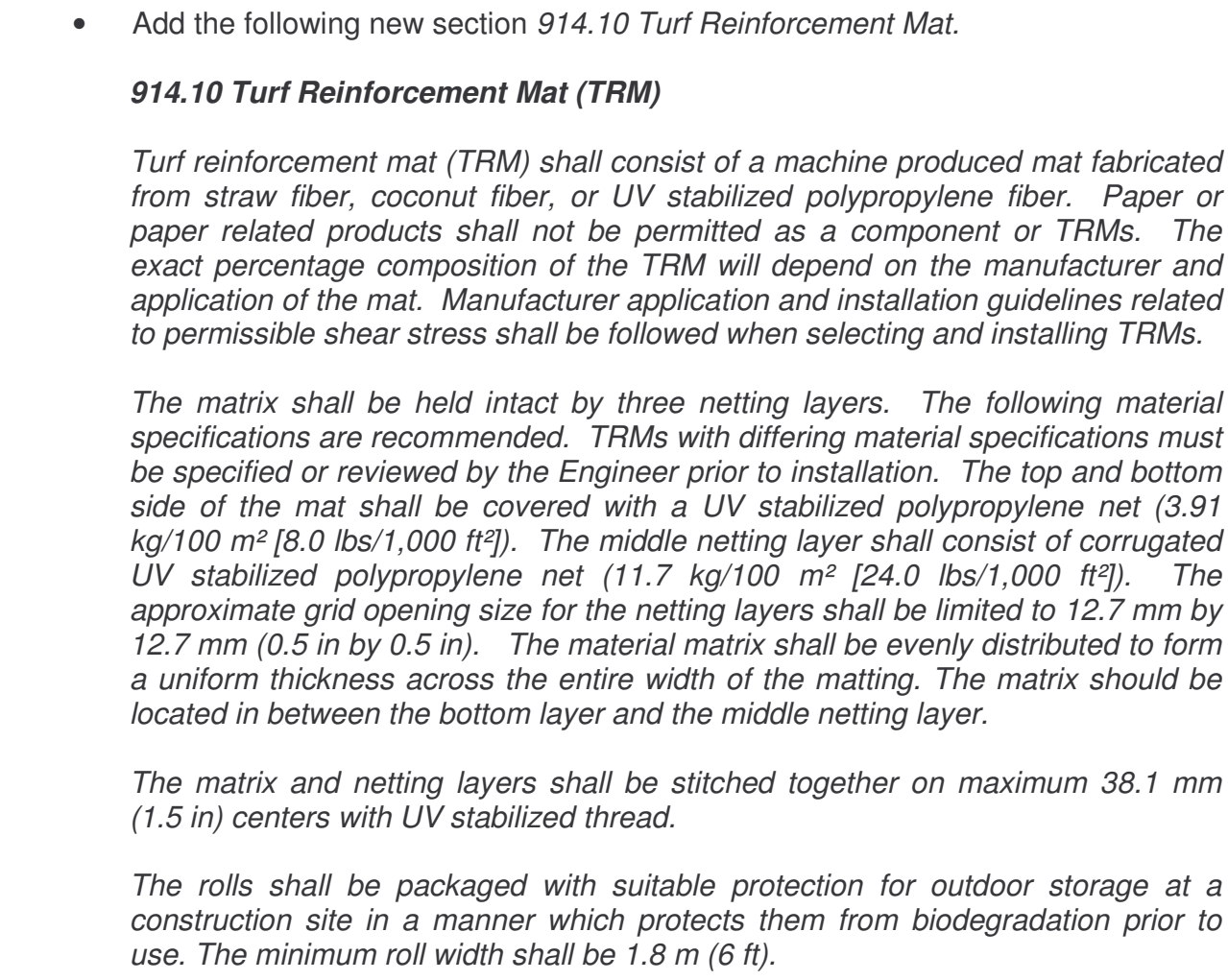 \\
\hline Document & INDOT Standard Specifications \\
\hline Reference Location & SECTION 200 - EARTHWORK \\
\hline Reference Location & SECTION 205 - TEMPORARY EROSION AND SEDIMENT CONTROL \\
\hline Reference Location & 205.02 Materials \\
\hline Proposed Revision & $\begin{array}{l}\text { - Add the following items alphabetically to the list of materials. Add the appropriate } \\
\text { section reference number: } \\
\text { Turf Reinforcement Mat (TRM) }\end{array}$ \\
\hline
\end{tabular}




\section{PART III - INDOT Standard Drawings}

\begin{tabular}{|c|c|}
\hline Document & INDOT Standard Drawings \\
\hline Reference Location & Section 200 - Earthwork \\
\hline Reference Drawing & E 205-TECS-04 (M 205-TECS-04) (Now Unassigned) (NEW DRAWING) \\
\hline Code Meaning & TECS - Temporary Erosion Control Slope \\
\hline Drawing Title & Rolled Erosion Control Product Installation (General) \\
\hline Proposed Revision & 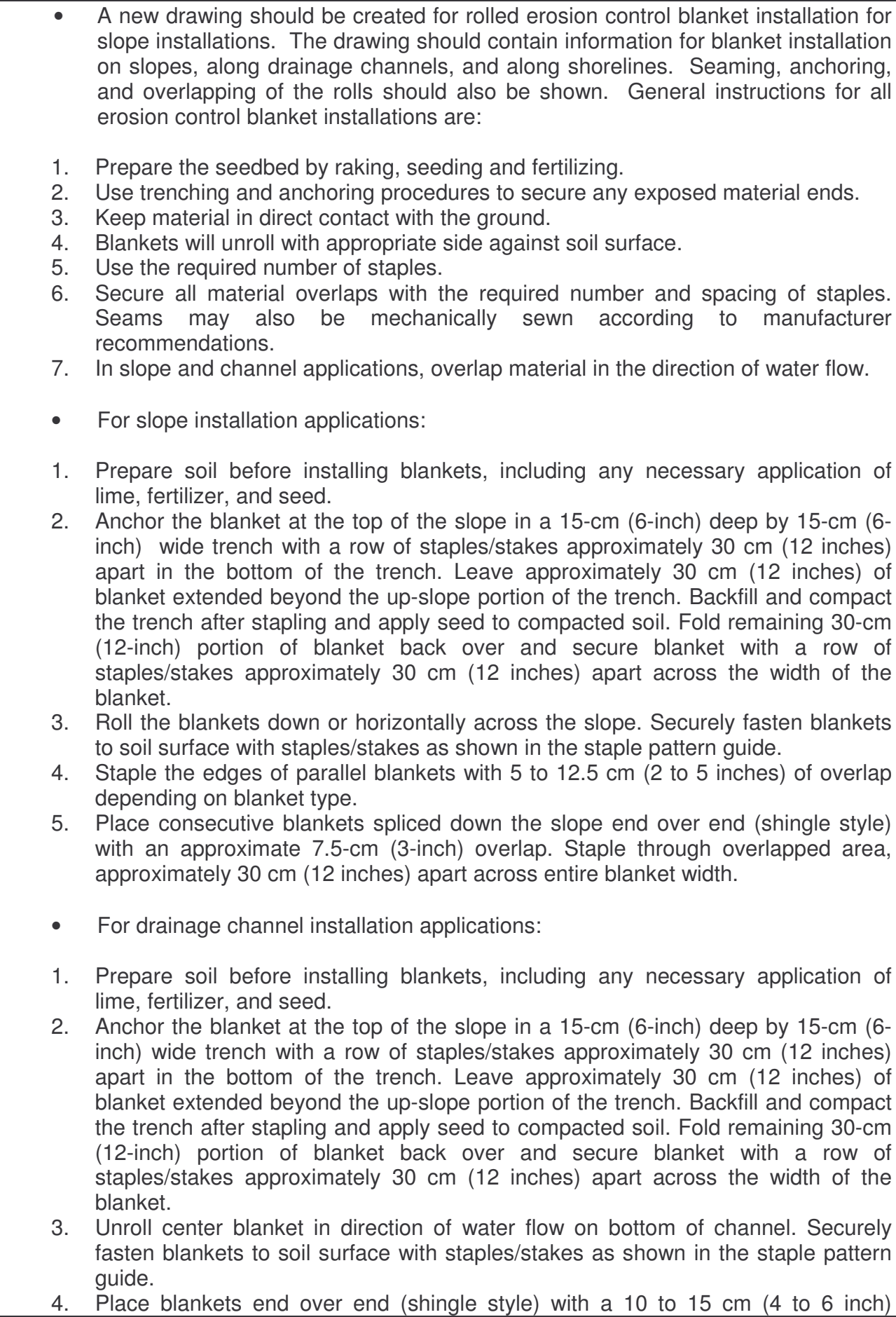 \\
\hline
\end{tabular}




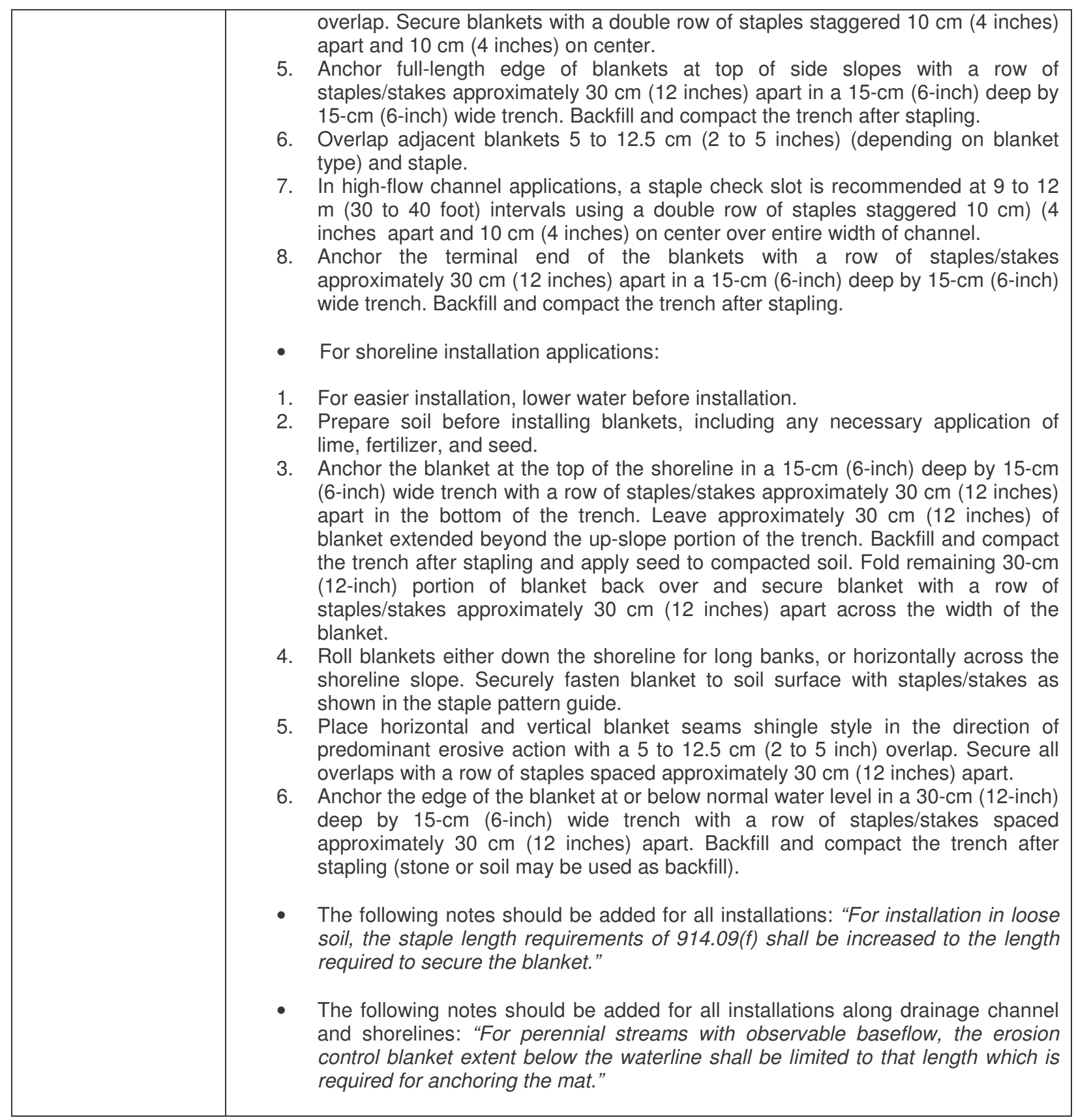




\begin{tabular}{|c|c|}
\hline Document & INDOT Standard Drawings \\
\hline Reference Location & Section 200 - Earthwork \\
\hline Reference Drawing & (NEW DRAWING) \\
\hline Code Meaning & Needs Code Assigned \\
\hline Drawing Title & Erosion Control Blanket Staple Patterns \\
\hline Proposed Revision & 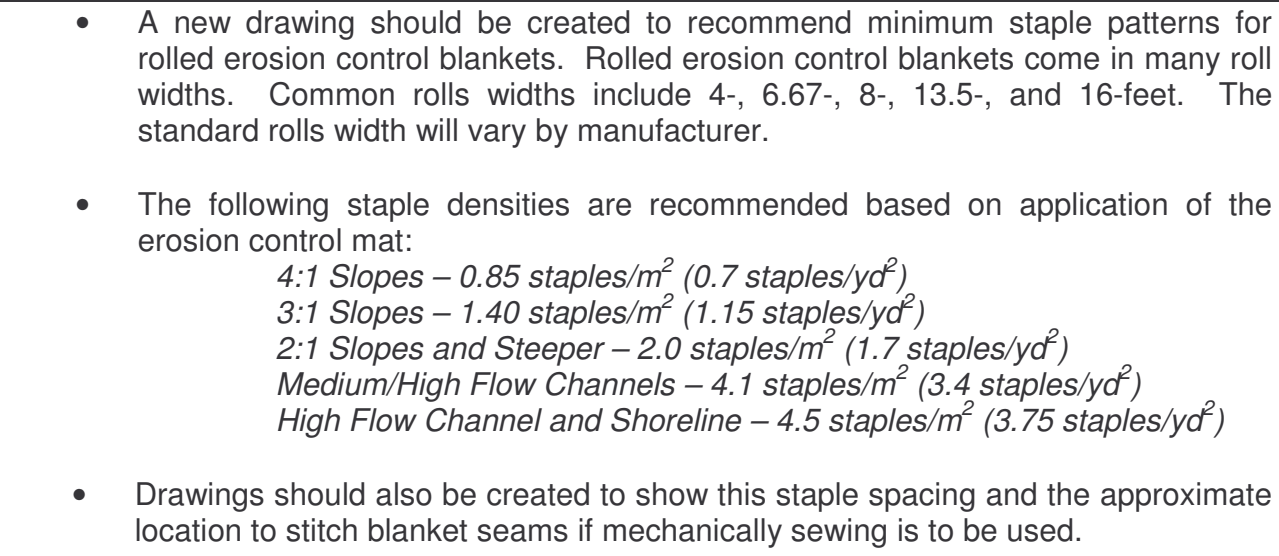 \\
\hline
\end{tabular}

\section{PART IV - INDOT Recurring Special Provisions}

No Recommended Revisions 


\section{Post-Construction Phase BMP Component - Water Quality Dry Swale}

\section{PART I - INDOT Design Manuals}

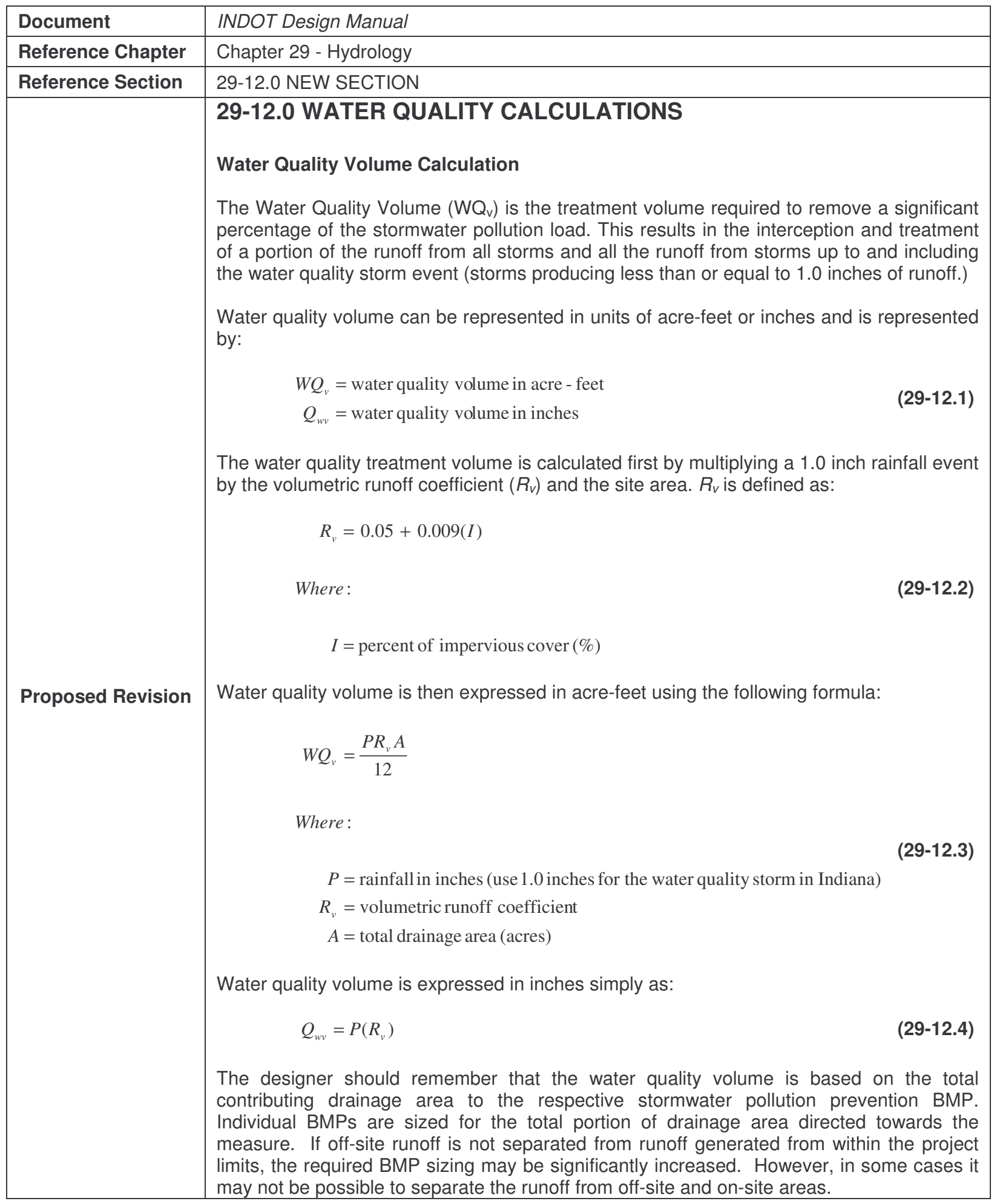




\section{PART II - INDOT Standard Specifications}

No Recommended Revisions

\section{PART III - INDOT Standard Drawings}

No Recommended Revisions

PART IV - INDOT Recurring Special Provisions

No Recommended Revisions 


\section{Post-Construction Phase BMP Component - Water Quality Structures (Hydrodynamic Separators)}

\section{PART I - INDOT Design Manuals}

\begin{tabular}{|c|c|}
\hline Document & DOT Design Manual \\
\hline Reference Chapter & Chapter 29 - Hydrology \\
\hline Reference Section & 29-12.0 NEW SECTION \\
\hline Proposed Revision & 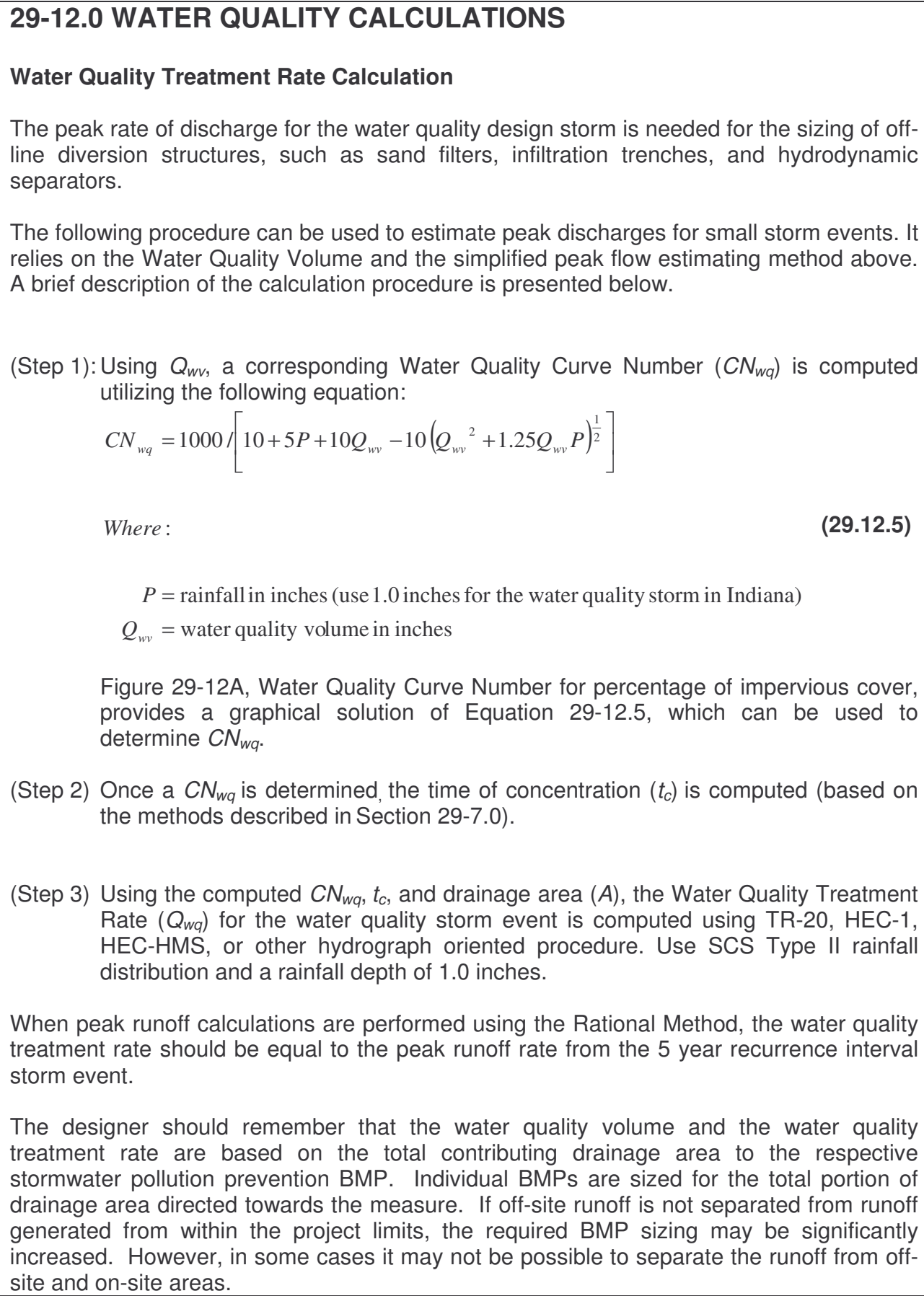 \\
\hline
\end{tabular}




\section{PART II - INDOT Standard Specifications}

\begin{tabular}{|c|c|}
\hline Document & INDOT Standard Specifications \\
\hline Reference Location & SECTION 700 - STRUCTURES \\
\hline Reference Location & SECTION 726 - WATER QUALITY STRUCTURES (NEW SECTION) \\
\hline Reference Location & NEW SECTION \\
\hline Proposed Revision & $\begin{array}{l}\text { - A new Standard Specification should be developed for water quality structures. } \\
\text { These types of structures may include catch basin inserts, hydrodynamic } \\
\text { separators, sand filters, or other structural water quality mechanisms. } \\
\text { Many of these structures are proprietary. INDOT will have to make a decision } \\
\text { which devices will be acceptable or recommended for use on INDOT projects; } \\
\text { however, since many of these water quality measures may have to be customized } \\
\text { by the Designer to meet site specific requirements, this information could also be } \\
\text { covered under INDOT recurring special provisions menu. } \\
\text { Regardless of where in the INDOT documents this information is added, some } \\
\text { general design parameters and procedures should be established for applicability } \\
\text { of various units. The development of such design procedures has been } \\
\text { referenced in this study's comment on the INDOT Design Manuals. } \\
\text { Parameters to consider include the following: } \\
\text { - Water quality treatment rate } \\
\text { - Particle removal efficiency (typically } 80 \% \text { TSS) } \\
\text { - Design particle size } \\
\text { indablishment of particular unit's particle removal efficiency, through } \\
\text { indent laboratory testing } \\
\text { Specific construction considerations that should be evaluated for stormwater } \\
\text { BMPs should included: } \\
\text { Timing of BMP installation. Most upstream areas should be stabilized } \\
\text { otherwise the BMP unit may "fill up" with sediment and require } \\
\text { maintenance. } \\
\text { Substitution. The stormwater BMP market is very competitive. There } \\
\text { are many vendors and all products are not equal. The Designer will } \\
\text { select a BMP unit based on detailed engineering analysis. If a } \\
\text { Contractor wants to substitute a different BMP, INDOT must decide who } \\
\text { must be financially responsible for proving to INDOT and the Designer } \\
\text { the proposed substitute will not present additional long-term } \\
\text { maintenance cost to INDOT and will provide equal or greater water } \\
\text { quality benefits than the originally designed unit. } \\
\text { Custom materials. Materials used in many BMP units are already } \\
\text { covered under the INDOT Standard Specifications (concrete, reinforcing } \\
\text { steel, B-Borrow, manholes, castings, etc.). However, the material } \\
\text { specifications of some custom proprietary components should be } \\
\text { considered by INDOT and the Designer. }\end{array}$ \\
\hline
\end{tabular}




\section{PART III - INDOT Standard Drawings}

\begin{tabular}{|c|c|}
\hline Document & INDOT Standard Drawings \\
\hline Reference Location & Section 726 - Water Quality Structures (NEW SECTION) \\
\hline Reference Drawing & (NEW DRAWINGS) \\
\hline Code Meaning & Needs Code Assigned \\
\hline Drawing Title & Water Quality Structure \\
\hline Proposed Revision & 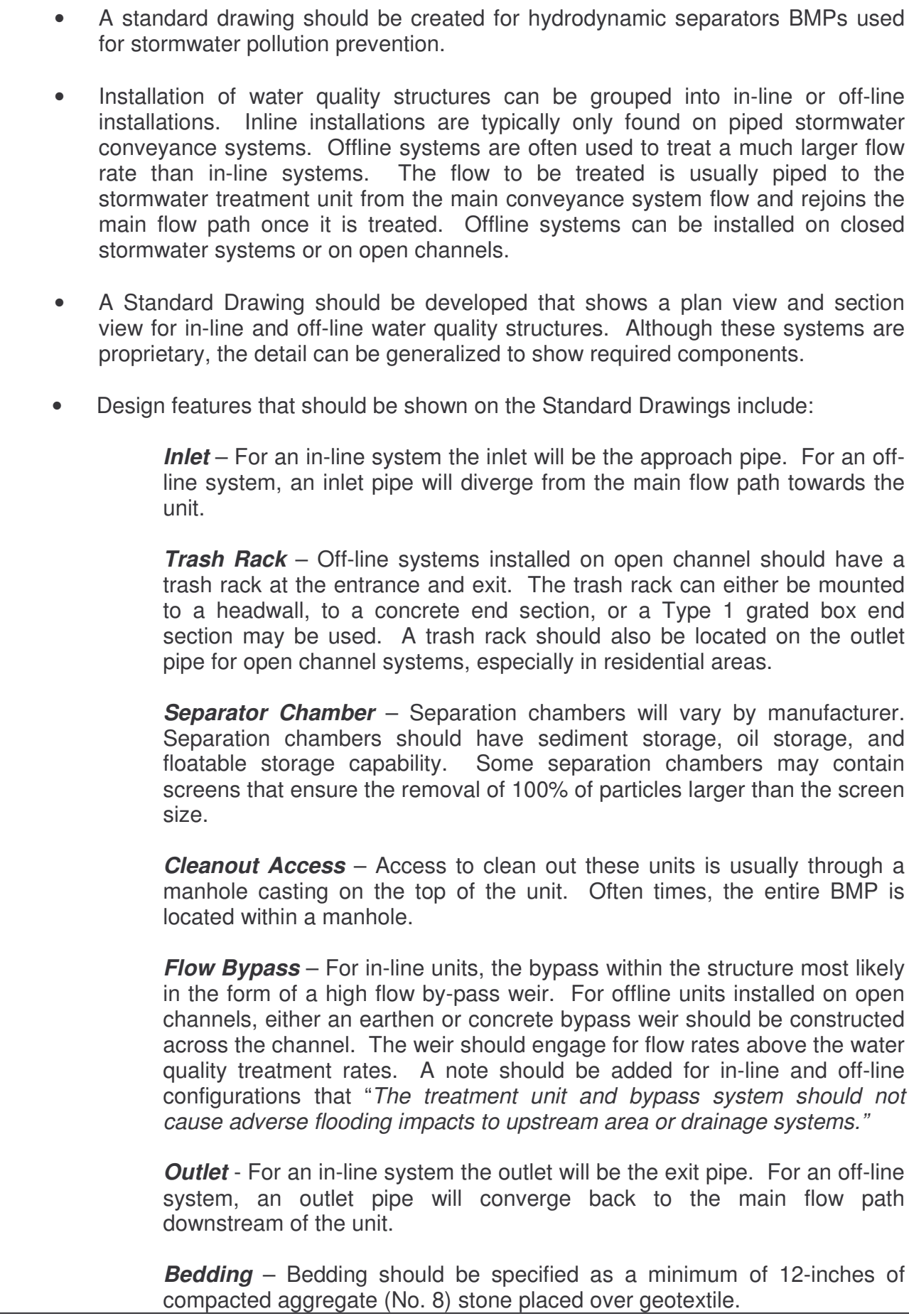 \\
\hline
\end{tabular}




\begin{tabular}{|l|l|}
\hline & $\begin{array}{l}\text { Backfill - Material obtained when excavating to place the structure may be } \\
\text { used as backfill if it is suitable. If material is not suitable, Structure Backfill } \\
\text { (Standard Specifications Section 904) shall be installed. All backfill shall } \\
\text { be compacted to a minimum of 95\% Standard Proctor. }\end{array}$ \\
\hline
\end{tabular}

\section{PART IV - INDOT Recurring Special Provisions}

No Recommended Revisions 


\section{Post-Construction Phase BMP Component - Water Quality Wet Swale}

\section{PART I - INDOT Design Manuals}

\begin{tabular}{|c|c|}
\hline \multirow{3}{*}{$\begin{array}{l}\text { Document } \\
\text { Reference Chapter } \\
\text { Reference Section }\end{array}$} & INDOT Design Manual \\
\hline & Chapter 29 - Hydrology \\
\hline & 29-12.0 NEW SECTION \\
\hline \multirow{12}{*}{ Proposed Revision } & $\begin{array}{l}\text { 29-12.0 WATER QUALITY CALCULATIONS } \\
\text { Water Quality Volume Calculation } \\
\text { The Water Quality Volume }\left(W_{v}\right) \text { is the treatment volume required to remove a significant } \\
\text { percentage of the stormwater pollution load. This results in the interception and treatment } \\
\text { of a portion of the runoff from all storms and all the runoff from storms up to and including } \\
\text { the water quality storm event (storms producing less than or equal to } 1.0 \text { inches of runoff.) } \\
\text { Water quality volume can be represented in units of acre-feet or inches and is represented } \\
\text { by: }\end{array}$ \\
\hline & $\begin{aligned} W Q_{v} & =\text { water quality volume in acre }- \text { feet } \\
Q_{w v} & =\text { water quality volume in inches }\end{aligned}$ \\
\hline & $\begin{array}{l}\text { The water quality treatment volume is calculated first by multiplying a } 1.0 \text { inch rainfall event } \\
\text { by the volumetric runoff coefficient }\left(R_{v}\right) \text { and the site area. } R_{v} \text { is defined as: } \\
\qquad R_{v}=0.05+0.009(I)\end{array}$ \\
\hline & $(29-12.2)$ \\
\hline & $I=$ percent of impervious cover $(\%)$ \\
\hline & $\begin{array}{l}\text { Water quality volume is then expressed in acre-feet using the following formula: } \\
\qquad W Q_{v}=\frac{P R_{v} A}{12}\end{array}$ \\
\hline & Where: \\
\hline & $(29-12.3)$ \\
\hline & $\begin{aligned} P & =\text { rainfall in inches (use } 1.0 \text { inches for the water quality storm in Indiana) } \\
R_{v} & =\text { volumetric runoff coefficient } \\
A & =\text { total drainage area (acres) }\end{aligned}$ \\
\hline & Water quality volume is expressed in inches simply as: \\
\hline & $Q_{w v}=P\left(R_{v}\right)$ \\
\hline & $\begin{array}{l}\text { The designer should remember that the water quality volume is based on the total } \\
\text { contributing drainage area to the respective stormwater pollution prevention BMP. } \\
\text { Individual BMPs are sized for the total portion of drainage area directed towards the } \\
\text { measure. If off-site runoff is not separated from runoff generated from within the project } \\
\text { limits, the required BMP sizing may be significantly increased. However, in some cases it } \\
\text { may not be possible to separate the runoff from off-site and on-site areas. }\end{array}$ \\
\hline
\end{tabular}




\section{PART II - INDOT Standard Specifications}

No Recommended Revisions

\section{PART III - INDOT Standard Drawings}

No Recommended Revisions

PART IV - INDOT Recurring Special Provisions

No Recommended Revisions 


\section{Miscellaneous Recommendations}




\section{General:}

This document is one part of a comprehensive review of INDOT documentation related to INDOT's Stormwater Quality Master Plan (SWQMP). The comments in this document are:

- comments that may apply to many construction phase or post-construction phase BMPs;

- important concepts or terminology changes related to construction phase or post-construction phase BMPs;

- procedural construction phase or post-construction phase items important to stormwater quality;

- other specific recommendations related to BMPs.

In general, the comments in this document are not specifically related to any one Construction Phase or Post-Construction Phase Best Management Practices (BMPs).

\section{Documents Covered:}

- INDOT Design Manuals

- INDOT Standard Specifications

- INDOT Recurring Special Provisions

- INDOT Standard Drawings

\section{Organization:}

Specific recommended revisions and additions to the above listed documents are summarized in the following tables. Comments have been grouped in the categories listed in the Table 1.

\section{Table 1: Recommended Revision and Addition Categories}

\section{Recommended Revision and Addition Categories}

Rule 5 Permitting, NOI, \& NOT

Recommended Goals, Objectives, \& Procedures

Design Plan Components

Terminology Updates and Definitions

Water Quality \& SWPPP

Miscellaneous Recommendations 


\section{BMP Comments -Miscellaneous Recommendations}

\section{Part I - Rule 5 Permitting, NOI, \& NOT}

It is the current understanding that INDOT is applying for an Individual Permit, rather than relying on the Regional Permit requirements governing specific MS-4 regions of the State. It is assumed that INDOT projects would be submitted directly to IDEM or the County SWCD as the permitting authority. Due to the current ongoing reorganization of the State government in relation to stormwater quality and erosion control plan review, it is unclear if this assumption would apply. However, if INDOT were required to submit to the MS-4 communities under Rule 13, additional minor revisions might be needed to address submittals or adherence to MS-4 community localized requirements.

\begin{tabular}{|l|l|}
\hline Document & INDOT Design Manual \\
\hline Reference Chapter & Chapter 37 - Temporary Erosion and Sediment Control \\
\hline Reference Section & General \\
\hline Proposed Revision & $\bullet \quad$ Change all references to 2 ha (5 acre) to 0.4 ha (1 acre) \\
\hline
\end{tabular}

\begin{tabular}{|l|c|}
\hline Document & INDOT Design Manual \\
\hline Reference Chapter & \begin{tabular}{l} 
Chapter $37-$ Temporary Erosion and Sediment Control \\
\hline Reference Section
\end{tabular} \\
\hline $\begin{array}{l}\text { Pr-1.0 GENERAL INFORMATION } \\
\text { Proposed Revision }\end{array}$ & $\begin{array}{l}\text { INDOT's approved NPDES Phase II permit and associated permit conditions } \\
\text { should be referenced in the third paragraph. }\end{array}$ \\
\hline
\end{tabular}

\begin{tabular}{|l|l|}
\hline Document & INDOT Design Manual \\
\hline Reference Chapter & Chapter 37 - Temporary Erosion and Sediment Control \\
\hline Reference Section & Figure 37-1A \\
\hline Proposed Revision & $\begin{array}{l}\text { The figure should be updated to incorporate all the information shown on the } \\
\text { attached Sample Rule 5 checklist. }\end{array}$ \\
\hline
\end{tabular}

\begin{tabular}{|c|c|}
\hline Document & INDOT Design Manual \\
\hline Reference Chapter & Chapter 37 - Temporary Erosion and Sediment Control \\
\hline Reference Section & 37-1.0 GENERAL INFORMATION \\
\hline Proposed Revision & $\begin{array}{l}\text { - Add the following sentence at the end of the third paragraph before ... The } \\
\text { submittal should be...: } \\
\text { The designer is responsible for all items listed in Figure } 37-1 A \text {, including parts } \\
A, B \text {, and } C \text {. }\end{array}$ \\
\hline
\end{tabular}




\begin{tabular}{|c|c|}
\hline Document & INDOT Standard Specifications \\
\hline Reference Location & SECTION 100 - GENERAL PROVISIONS \\
\hline Reference Location & SECTION 107 - LEGAL RELATIONS AND RESPONSIBILITY TO PUBLIC \\
\hline Reference Location & 107.02 Permits, Licenses, and Taxes \\
\hline Proposed Revision & $\begin{array}{l}\text { - In paragraph } 3 \text {, add Notice of Intent (NOI) to the list of permits the Department } \\
\text { may have acquired. } \\
\text { - Add the following text as paragraph 4: } \\
\text { When the project is substantially complete, the Contractor shall provide the } \\
\text { Department information certifying that all conditions for the NPDES Notice of } \\
\text { Termination (NOT) have been satisfied. The Department will apply for the } \\
\text { NOT once the information has been provided by the Contractor. }\end{array}$ \\
\hline
\end{tabular}

\begin{tabular}{|l|l|}
\hline Document & INDOT Standard Specifications \\
\hline Reference Location & SECTION 100 - GENERAL PROVISIONS \\
\hline Reference Location & SECTION 107 - LEGAL RELATIONS AND RESPONSIBILITY TO PUBLIC \\
\hline Reference Location & \begin{tabular}{c}
107.23 Waiver of Legal Rights \\
\hline Proposed Revision
\end{tabular}$\quad \begin{array}{l}\text { Add as the second sentence, "The NOT shall be accepted by IDEM prior to final } \\
\text { inspection. See 107.02 for the Contractor's NOT requirements." }\end{array}$ \\
\hline
\end{tabular}

\begin{tabular}{|l|l|}
\hline Document & INDOT Standard Specifications \\
\hline Reference Location & SECTION 100-GENERAL PROVISIONS \\
\hline Reference Location & SECTION 108 - PROSECUTION AND PROGRESS \\
\hline Reference Location & \begin{tabular}{c} 
108.04 Prosecution of Work \\
\hline Pdd the following sentence at the end of the tenth paragraph: \\
Upstream areas must be stabilized before permanent sediment control BMP \\
measures are installed unless sediment maintenance of such measures is to \\
be performed by the Contractor on a more frequent basis, including \\
immediately prior to providing the Department information for the NPDES \\
Notice of Termination (NOT.)
\end{tabular} \\
\hline
\end{tabular}

\begin{tabular}{|l|l|}
\hline Document & INDOT Standard Specifications \\
\hline Reference Location & SECTION 100-GENERAL PROVISIONS \\
\hline Reference Location & SECTION 109-MEASUREMENT AND PAYMENT \\
\hline Reference Location & \begin{tabular}{c} 
109.08 Final Payment \\
\hline Proposed Revision
\end{tabular} \\
& $\begin{array}{r}\text { Add the following sentence as the last sentence in the third paragraph: } \\
\text { certifies that all conditions for the NPDES Permit have been met. }\end{array}$ \\
\hline
\end{tabular}




\section{Part II - Goals, Objectives, \& Procedures}

\begin{tabular}{|c|c|}
\hline Document & INDOT Design Manual \\
\hline Reference Chapter & Chapter 1 - INDOT Organization \\
\hline Reference Section & 1-3.01(02) Engineering Services Section \\
\hline Proposed Revision & $\begin{array}{l}\text { - Possibly add the following item to list of Engineering Services Sections - } \\
\text { Hydraulics Unit functions: } \\
\text { acting as a contact for questions and providing technical support regarding } \\
\text { INDOT requirements for water quality, Stormwater Pollution Prevention Plans } \\
\text { (SWPPPS), and Stormwater Best Management Practices (BMPS) }\end{array}$ \\
\hline
\end{tabular}

\begin{tabular}{|c|c|}
\hline Document & INDOT Design Manual \\
\hline Reference Chapter & Chapter 1 - INDOT Organization \\
\hline Reference Section & 1-3.01(02) Engineering Services Section \\
\hline Proposed Revision & $\begin{array}{l}\text { - Add Notice of Intent (NOI) and Notice of Termination (NOT) to lists of example } \\
\text { permits submitted by the Hydraulic Units listed as point } \underline{e} \text { under Section } 1 \\
\text { Hydraulics. }\end{array}$ \\
\hline
\end{tabular}

\begin{tabular}{|c|c|}
\hline Document & INDOT Design Manual \\
\hline Reference Chapter & Chapter 3 - Project Design Coordination \\
\hline Reference Section & 3-1.01(01) Hydraulics Unit \\
\hline Proposed Revision & $\begin{array}{l}\text { - Change Item 5. to Stormwater Pollution Prevention Plan } \\
\text { Modify the paragraph under Item } 5 \text { to read: } \\
\text { The designer has the primary responsibility to develop the plan for } \\
\text { construction phase Best Management Practices (BMPS) for temporary } \\
\text { erosion and sediment control. The designer will also be primarily responsible } \\
\text { for specifying design elements of post-construction BMPs for stormwater } \\
\text { pollution prevention. Utilizing the elements of the construction and post- } \\
\text { construction storm water quality BMPs, the designer will be responsible for } \\
\text { preparing, submitting, and obtaining the stormwater quality technical review } \\
\text { approval as applicable. Once approval is gained, INDOT will be responsible } \\
\text { for submitting the NOI and NOT. }\end{array}$ \\
\hline
\end{tabular}

\begin{tabular}{|c|c|}
\hline Document & INDOT Design Manual \\
\hline Reference Chapter & Chapter 5 - Engineering Assessment \\
\hline Reference Section & 5-1.0 Engineering Assessment Section \\
\hline Proposed Revision & $\begin{array}{l}\text { - General comment. Under point } 2 \text { one of the section's mission is provided as: } \\
\text { 2. integrate engineering/transportation and environmental objectives. }\end{array}$ \\
\hline
\end{tabular}

\begin{tabular}{|c|c|}
\hline Document & INDOT Design Manual \\
\hline Reference Chapter & Chapter 5 - Engineering Assessment \\
\hline Reference Section & $5-2.03(03)$ \\
\hline Proposed Revision & $\begin{array}{l}\text { - } \quad \text { Add the following item to the end of point } 6 \text { : } \\
\text { including existing stormwater pollution prevention or water quality features. }\end{array}$ \\
\hline
\end{tabular}




\begin{tabular}{|l|c|}
\hline Document & INDOT Design Manual \\
\hline Reference Chapter & Chapter 35 - Storage Facilities \\
\hline Reference Section & 35-12.0 LAND-LOCKED RETENTION \\
\hline Proposed Revision & Add the following paragraph at the end of the section: \\
& $\begin{array}{l}\text { Under no circumstances should treated or untreated stormwater runoff be } \\
\text { intentionally directed towards karst areas (sinkholes.) In general, natural } \\
\text { drainage rates towards karst regions should not be modified. }\end{array}$ \\
\hline
\end{tabular}

\begin{tabular}{|l|c|}
\hline Document & INDOT Design Manual \\
\hline Reference Chapter & Chapter 36 - Pavement/Storm Drainage Systems \\
\hline Reference Section & \begin{tabular}{l}
$36-2.01$ Introduction \\
\hline Proposed Revision
\end{tabular} \\
& $\begin{array}{c}\text { Sdd the following sentence at the end of the first paragraph: } \\
\text { addressed in the design process of storm drainage systems. }\end{array}$ \\
\hline
\end{tabular}

\begin{tabular}{|l|c|}
\hline Document & INDOT Design Manual \\
\hline Reference Chapter & Chapter 36 - Pavement/Storm Drainage Systems \\
\hline Reference Section & \begin{tabular}{c}
$36-2.02$ Bridge Decks \\
\hline Proposed Revision
\end{tabular} \\
& $\begin{array}{l}\text { Add the following to the end of the second to the last sentence: } \\
\text { Pollution Prevention (SWPPP) requirements. }\end{array}$ \\
\hline
\end{tabular}

\begin{tabular}{|l|c|}
\hline Document & INDOT Design Manual \\
\hline Reference Chapter & Chapter 36 - Pavement/Storm Drainage Systems \\
\hline Reference Section & 36-5.03 Required Data \\
\hline & $\begin{array}{c}\text { Change the last sentence in the first paragraph to read: } \\
\text { Proposed Revision }\end{array}$ \\
& $\begin{array}{l}\text { Water quality requirements should be considered in all areas, particularly in } \\
\text { environmentally sensitive areas. }\end{array}$ \\
\hline
\end{tabular}

\begin{tabular}{|l|c|}
\hline Document & INDOT Design Manual \\
\hline Reference Chapter & Chapter 37 - Temporary Erosion and Sediment Control \\
\hline Reference Section & \begin{tabular}{l} 
37-1.0 GENERAL INFORMATION \\
\hline Proposed Revision
\end{tabular} \\
& $\begin{array}{l}\text { The goals of erosion and sediment control are different. The purpose of } \\
\text { erosion control measures is to prevent sediment from being mobilized on the } \\
\text { project site. Sediment control measures are designed to recapture soil that } \\
\text { has been mobilized and prevent it from leaving the construction site. }\end{array}$ \\
\hline
\end{tabular}




\begin{tabular}{|l|c|}
\hline Document & INDOT Design Manual \\
\hline Reference Chapter & Chapter 30 - Channels \\
\hline Reference Section & 30-1.02 Significance \\
\hline Proposed Revision & $\begin{array}{c}\text { Add the following as point number 7 } \\
\end{array}$ \\
\hline
\end{tabular}

\begin{tabular}{|c|c|}
\hline Document & INDOT Design Manual \\
\hline Reference Location & Chapter 33 - Bridge Deck Drainage \\
\hline Reference Location & 33-1.02(07) NEW SECTION \\
\hline Proposed Revision & $\begin{array}{l}\text { - Add the following as section 33-1.02(07) as a design objective of bridge deck } \\
\text { drainage: } \\
\text { 33-1.02(07) Protection of Water Quality } \\
\text { Stormwater pollution prevention treatment measures are needed in the } \\
\text { design of bridge deck drainage systems if the overall construction project } \\
\text { impacts more than } 0.4 \text { ha (1 acre) as indicated in Section } 9-1.02 \text {. Measures } \\
\text { must be placed accordingly such that a portion of runoff from all storm events } \\
\text { and all the runoff from the water quality storm event are treated before the } \\
\text { stormwater runoff leaves the INDOT right-of-way. } \\
\text { If stormwater pollution prevention measures can not be added to the bridge } \\
\text { deck drainage system or are determined to be cost prohibitive, stormwater } \\
\text { pollution prevention mitigation must be performed within the same watershed. } \\
\text { Such mitigation measures may include constructed wetlands, stream bank } \\
\text { stabilization, or retrofitting of detention ponds. }\end{array}$ \\
\hline
\end{tabular}

\begin{tabular}{|l|c|}
\hline Document & INDOT Design Manual \\
\hline Reference Chapter & Chapter 35 - Storage Facilities \\
\hline Reference Section & \begin{tabular}{c} 
35-2.01 Introduction \\
\hline Proposed Revision
\end{tabular} \\
& $\begin{array}{l}\text { Add the following item to the list of potential benefits of controlling the quantity of } \\
\text { stormwater by using storage facilities: } \\
\text { 5. improvement of downstream water quality through stormwater pollution } \\
\text { prevention features. }\end{array}$ \\
\hline
\end{tabular}

\begin{tabular}{|l|c|}
\hline Document & INDOT Design Manual \\
\hline Reference Chapter & Chapter 35 - Storage Facilities \\
\hline Reference Section & 35-4.01 General Criteria \\
\hline Proposed Revision & $\begin{array}{c}\text { Add the following item to the list of general design criteria for storage facilities: } \\
\end{array}$ \\
\hline
\end{tabular}




\begin{tabular}{|c|c|}
\hline Document & INDOT Design Manual \\
\hline Reference Chapter & Chapter 37 - Temporary Erosion and Sediment Control \\
\hline Reference Section & 37-2.0 SITE ANALYSIS \\
\hline Proposed Revision & $\begin{array}{l}\text { - Modify the following items under the list of principles of erosion and sediment } \\
\text { control: } \\
\text { 3. Where reasonable, perimeter dikes and waterways should be used to } \\
\text { divert/intercept off-site runoff. When evaluating the decision as to whether } \\
\text { diversion/interception of off-site runoff is reasonable, the increased sizing of } \\
\text { proposed BMP structures to treat off-site runoff if such diversion is not } \\
\text { performed should also be considered. } \\
\text { 8. The amount of disturbed area on the construction site should be } \\
\text { minimized through construction phasing. Incremental final stabilization of } \\
\text { areas should be promoted where such measures can adequately meet the } \\
\text { intended use requirements of these areas. } \\
\text { 9. The impervious surface should be kept at the minimum required to meet } \\
\text { public safety needs. The use of porous material should be encouraged } \\
\text { outside of the mainline pavement areas. } \\
\text { Replace the last sentence of the final paragraph with: } \\
\text { Within the construction clear zone, straw bales, fiber wattle rolls, or other } \\
\text { approved means, should be used instead of riprap. }\end{array}$ \\
\hline
\end{tabular}




\section{Part III - Design Plan Components}

\begin{tabular}{|c|c|}
\hline Document & INDOT Design Manual \\
\hline Reference Chapter & Chapter 14 - Plan Development \\
\hline Reference Section & 14-2.01(03) Preliminary Field Check Plans \\
\hline Proposed Revision & $\begin{array}{l}\text { - Add "post-construction stormwater pollution prevention BMPs" as point } 4 i \text { as an } \\
\text { element to be included on the Plan and Profile Sheets for the Preliminary Field } \\
\text { Check Plans Submittal. } \\
\text { - Add "post-construction stormwater pollution prevention BMPs" as point } 5 j \text { as an } \\
\text { element to be included on the Detail Sheets for the Preliminary Field Check Plans } \\
\text { Submittal. } \\
\text { - Add "post-construction stormwater pollution prevention BMPs, where applicable" } \\
\text { as point } 9 f \text { as an element to be included on the Cross Section Sheets for the } \\
\text { Preliminary Field Check Plans Submittal. }\end{array}$ \\
\hline
\end{tabular}

\begin{tabular}{|c|c|}
\hline Document & INDOT Design Manual \\
\hline Reference Chapter & Chapter 14 - Plan Development \\
\hline Reference Section & 14-2.01(07) Final Field Check Plans Submission \\
\hline Proposed Revision & $\begin{array}{l}\text { - Modify point } 2 d \text { to read } \\
\text { Detail Sheets. Ensure all details are completed and included with this } \\
\text { submission. This includes traffic maintenance details and traffic design } \\
\text { elements (e.g., intersections, signals, signing and lighting). This also } \\
\text { includes details and notes for the temporary erosion and sediment control } \\
\text { and post-construction Stormwater Pollution Prevention Plans. } \\
\text { - Add the following to Part } 4 \text { Computation and Miscellaneous Documents } \\
\text { "erosion and sediment control feature design" as point } 4 i \text {. } \\
\text { "post-construction stormwater pollution prevention BMP design" as point } 4 j \text {. }\end{array}$ \\
\hline
\end{tabular}

\begin{tabular}{|l|l|}
\hline Document & INDOT Design Manual \\
\hline Reference Chapter & Chapter 14 - Plan Development \\
\hline Reference Section & 14-2.01(08) Final Check Prints Submission \\
\hline & $\begin{array}{r}\text { Revise Point 10 to read: } \\
\text { Proposed Revision }\end{array}$ \\
& $\begin{array}{l}\text { 10. NPDES Phase II Permit Review If required under Section 9-1.02, include } \\
\text { the completed set of details and notes for the post-construction Stormwater } \\
\text { Pollution Prevention Plan and other supporting documentation used for the } \\
\text { NPDES Phase II permit submittal, as described in Chapter Thirty-Seven. }\end{array}$ \\
\hline
\end{tabular}




\begin{tabular}{|c|c|}
\hline Document & INDOT Design Manual \\
\hline Reference Chapter & Chapter 14 - Plan Development \\
\hline Reference Section & 14-2.02(01) Grade Review Submission/Preliminary Field Check \\
\hline Proposed Revision & $\begin{array}{l}\text { - } \quad \text { Add "post-construction stormwater pollution prevention BMPs" as point } 6 / \text { as an } \\
\text { element to be included on the Plan and Profile Sheets. } \\
\text { - } \quad \text { Add "post-construction stormwater pollution prevention BMPs" as point } 81 \text { as an } \\
\text { element to be included on the Detail Sheets. } \\
\text { - Add "post-construction stormwater pollution prevention BMPs, where possible to } \\
\text { show" as point } 14 \mathrm{~g} \text { as an element to be included on the Cross Section Sheets. }\end{array}$ \\
\hline
\end{tabular}

\begin{tabular}{|l|c|}
\hline Document & INDOT Design Manual \\
\hline Reference Chapter & Chapter 14 - Plan Development \\
\hline Reference Section & \begin{tabular}{l} 
14-2.02(03) Final Design Summary Submission \\
\hline Proposed Revision
\end{tabular} \\
& 4. necessary permit support and SWPPP information; and \\
\hline
\end{tabular}

\begin{tabular}{|c|c|}
\hline Document & INDOT Design Manual \\
\hline Reference Chapter & Chapter 14 - Plan Development \\
\hline Reference Section & 14-2.02(05) Final Check Prints Submission \\
\hline Proposed Revision & $\begin{array}{l}\text { - Modify point } 3 d \text { to read } \\
\text { Detail Sheets. Ensure all details are completed and included with this } \\
\text { submission. This includes details for traffic maintenance details and traffic } \\
\text { design elements (e.g., intersections, signals, signing and lighting). This also } \\
\text { includes details and notes for the temporary erosion and sediment control } \\
\text { and post-construction Stormwater Pollution Prevention Plans. } \\
\text { - Add the following to Part } 4 \text { Computation and Miscellaneous Documents } \\
\text { "erosion and sediment control feature design" as point } 4 \text {. } \\
\text { "post-construction stormwater pollution prevention BMP design" as point 4j. } \\
\text { Add Point } 11 \text { as: } \\
\text { 11. Post-Construction Stormwater Pollution Prevention Plans. Include the } \\
\text { completed set of details and notes for the post-construction Stormwater } \\
\text { Pollution Prevention Plan (SWPPP) and supporting documentation used for } \\
\text { the NPDES Phase II permit submittal. } \\
\text { Change existing Point } 11 \text { to Point } 12 \text { and modify to read: } \\
\text { 12. NPDES Phase II. If required as described in Section 9-1.02, complete } \\
\text { the NPDES Phase II Permit submission as described in Chapter Thirty- } \\
\text { Seven. }\end{array}$ \\
\hline
\end{tabular}




\begin{tabular}{|c|c|}
\hline Document & INDOT Design Manual \\
\hline Reference Chapter & Chapter 14 - Plan Development \\
\hline Reference Section & 14-2.03(03) Preliminary Field Check Plans \\
\hline Proposed Revision & $\begin{array}{l}\text { - Add "post-construction stormwater pollution prevention BMPs" as point } 4 g \text { as an } \\
\text { element to be included on the Road Plan and Profile Sheets. } \\
\text { - Add "post-construction stormwater pollution prevention BMPs" as point } 5 e \text { as an } \\
\text { element to be included on the Detail Sheets. } \\
\text { - Add "post-construction stormwater pollution prevention BMPs for bridge structure, } \\
\text { if applicable" as point } 7 f \text { as an element to be included on the General Plan Sheet. } \\
\text { - Change the last sentence in Point } 9 \text { to read: } \\
\text { Also show the public road approaches and drive and, where possible, the } \\
\text { post-construction stormwater pollution prevention BMPs. }\end{array}$ \\
\hline
\end{tabular}

\begin{tabular}{|c|c|}
\hline Document & INDOT Design Manual \\
\hline Reference Chapter & Chapter 14 - Plan Development \\
\hline Reference Section & 14-2.03(07) Final Check Prints Submission \\
\hline Proposed Revision & $\begin{array}{l}\text { - Add "erosion and sediment control feature design" as point } 4 s \text { under Computation } \\
\text { and Quantities to be provided to INDOT. } \\
\text { - } \quad \text { Add "post-construction stormwater pollution prevention BMP design" as point } 4 t \\
\text { under Computation and Quantities to be provided to INDOT. } \\
\text { - Add "post-construction stormwater pollution prevention BMP details" as point } \\
6 d(3) \text {. } \\
\text { - Change Point } 8 \text { to read: Rule } 5 \text { / Rule } 13 \text { Submission }\end{array}$ \\
\hline
\end{tabular}

\begin{tabular}{|c|c|}
\hline Document & INDOT Design Manual \\
\hline Reference Chapter & Chapter 14 - Plan Development \\
\hline Reference Section & 14-2.04(03) Preliminary Plans Submission \\
\hline Proposed Revision & $\begin{array}{l}\text { - Modify } 4 f \text { to read: } \\
\text { f. general rehabilitation recommendations (e.g., legend, material notes, stormwater } \\
\text { pollution prevention retrofits needed). } \\
\text { - } \quad \text { Add "post-construction stormwater pollution prevention BMPs" as point } 4 \mathrm{~g} \text {. }\end{array}$ \\
\hline
\end{tabular}

\begin{tabular}{|l|c|}
\hline Document & INDOT Design Manual \\
\hline Reference Chapter & Chapter 14 - Plan Development \\
\hline Reference Section & $\begin{array}{c}14-3.07(01) \text { Road Projects } \\
\text { Proposed Revision }\end{array}$ \\
& Modify Point 9i to read: \\
& i. Erosion and Sediment Control and Post-Construction Stormwater Pollution \\
\hline
\end{tabular}




\begin{tabular}{|l|c|}
\hline Document & INDOT Design Manual \\
\hline Reference Chapter & Chapter 14 - Plan Development \\
\hline Reference Section & \begin{tabular}{c} 
14-3.07(02) Bridge Projects \\
\hline Proposed Revision
\end{tabular} \\
& i. Erosion and Sediment Control and Post-Construction Stormwater Pollution \\
& Prevention Control Detail (plan view); \\
\hline
\end{tabular}

\begin{tabular}{|l|c|}
\hline Document & INDOT Design Manual \\
\hline Reference Chapter & Chapter 14 - Plan Development \\
\hline Reference Section & Figure 14-1A \\
\hline Proposed Revision & $\begin{array}{l}\text { Add Post-Construction Stormwater Pollution Prevention Detail (Post-Construction } \\
\text { SWPPP) details to the table after Erosion and Sediment Control Detail. }\end{array}$ \\
\hline
\end{tabular}




\section{Part IV - Terminology \& Definitions}

\begin{tabular}{|l|l|}
\hline Document & INDOT Design Manual \\
\hline Reference Chapter & General \\
\hline Reference Section & General \\
\hline Proposed Revision & $\bullet \quad$ Change Erosion Control Plan to Erosion and Sediment Control Plan \\
& $-\quad$ Suggestion - provide the English unit equivalent where SI units are used \\
\hline
\end{tabular}

\begin{tabular}{|c|c|}
\hline Document & INDOT Design Manual \\
\hline Reference Chapter & Chapter 29 - Hydrology \\
\hline Reference Section & 29-4.0 Concept Definitions \\
\hline Proposed Revision & $\begin{array}{l}\text { - Add the following concepts to the list of hydrology concepts: } \\
\text { Curve Number: NRCS (formerly SCS) Curve Number, denoted as CN. The } \\
\text { Curve Number is a variable used in hydrograph based runoff calculations. It } \\
\text { represents soil type and permeability characteristics, land use, and cover } \\
\text { conditions of a given area. } \\
\text { Volumetric Runoff Coefficient: The volumetric runoff coefficient denoted as } R_{v} \\
\text { is used in water quality calculations. It represents the portion of rainfall that } \\
\text { becomes runoff and is dependent on percentage of impervious cover. } \\
\text { Water Quality Curve Number: The Water Quality Curve Number is used to } \\
\text { determine the water quality treatment rate. It is denoted at CNwq and is } \\
\text { dependent on the water quality volume, Qwv. The Water Quality Curve } \\
\text { Number is typically greater than the NRCS Curve Number used for traditional } \\
\text { hydrograph oriented peak runoff computations. } \\
\text { Water Quality Volume: Water quality volume is the treatment volume or } \\
\text { accumulated direct runoff depth that should be treated to remove a significant } \\
\text { percentage of the stormwater pollution load (approximately } 80 \% \text { of the } \\
\text { average annual post-development total suspended solids loading). Water } \\
\text { qualify volume is denoted by WQ } Q_{v} \text { for units of acre-feet and } Q_{w v} \text { for units of } \\
\text { inches. WQ W is used to design detention-based water quality treatment } \\
\text { systems such as a stormwater wetland, wet detention pond, or water quality } \\
\text { swale. } \\
\text { Water Quality Treatment Rate: The water quality treatment rate, denoted by } \\
\text { Qwq, is the design flow rate for flow through water quality systems. Properly } \\
\text { designed flow through systems, such as an infiltration trench or } \\
\text { hydrodynamic separator, must be able to meet pollutant removal } \\
\text { requirements at the design flow rate and be able to bypass inflows greater } \\
\text { than the design treatment rate. }\end{array}$ \\
\hline
\end{tabular}

\begin{tabular}{|l|l|}
\hline Document & INDOT Standard Drawings \\
\hline Reference Location & General \\
\hline Reference Drawing & General \\
\hline Code Meaning & General \\
\hline Drawing Title & General \\
\hline Proposed Revision & $\begin{array}{l}\text { The proposed revisions or additions discussed below should be made to both the } \\
\text { English and Metric Standard Drawings. To facilitate document organization and } \\
\text { to avoid confusion, where only metric drawings have been commented on, it } \\
\text { should be understood the additional need to update the English drawing as well. }\end{array}$ \\
\hline
\end{tabular}




\begin{tabular}{|l|l|}
\hline Document & INDOT Standard Drawings \\
\hline Reference Location & General \\
\hline Reference Drawing & General \\
\hline Code Meaning & General \\
\hline Drawing Title & General \\
\hline Proposed Revision & $\bullet \quad \begin{array}{l}\text { Change "Temporary Erosion Control" to "Temporary Erosion and Sediment } \\
\text { Control" where it occurs. }\end{array}$ \\
\hline
\end{tabular}

\begin{tabular}{|l|c|}
\hline Document & INDOT Standard Specifications \\
\hline Reference Location & General Comment \\
\hline Reference Location & General Comment \\
\hline Reference Location & General Comment \\
\hline Proposed Revision & $\bullet \quad$ Replace Erosion Control plan with: \\
& Erosion and Sediment Control Plan \\
\hline
\end{tabular}

\begin{tabular}{|l|c|}
\hline Document & INDOT Standard Specifications \\
\hline Reference Location & SECTION 100 - GENERAL PROVISIONS \\
\hline Reference Location & SECTION 101 - DEFINITIONS AND TERMS \\
\hline Reference Location & 101.01 Abbreviations \\
\hline & Add the following abbreviations to the current list: \\
& BFM - Bonded Fiber Matrix \\
& BMP - Best Management Practice \\
& MS4 - Municipal Separate Storm Sewer Systems \\
POI - Notice of Intent \\
NOT - Notice of Termination \\
NPDES - National Pollutant Discharge Elimination System \\
SWCD - Soil and Water Conservation District \\
SWPPP - Stormwater Pollution Prevention Plan \\
TRM - Turf Reinforcement Mat \\
\hline
\end{tabular}




\begin{tabular}{|c|c|}
\hline Document & INDOT Standard Specifications \\
\hline Reference Location & SECTION 100 - GENERAL PROVISIONS \\
\hline Reference Location & SECTION 101 - DEFINITIONS AND TERMS \\
\hline Reference Location & Impacts existing Section 101.02 through 101.68 \\
\hline Proposed Revision & 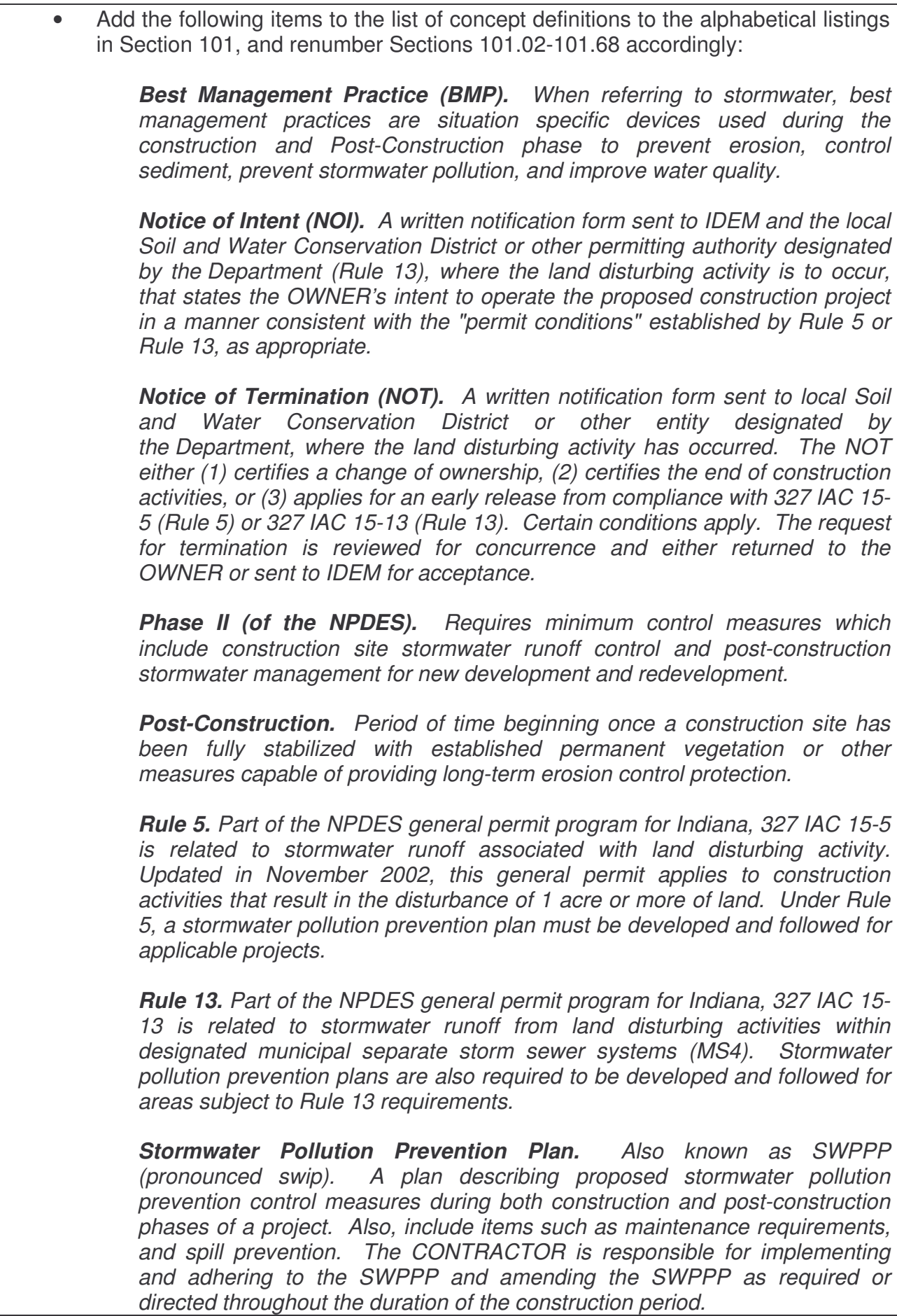 \\
\hline
\end{tabular}




\begin{tabular}{|l|l|}
\hline Document & INDOT Standard Specifications \\
\hline Reference Location & SECTION 100 - GENERAL PROVISIONS \\
\hline Reference Location & SECTION 107 - LEGAL RELATIONS AND RESPONSIBILITY TO PUBLIC \\
\hline Reference Location & 107.15 Erosion Control Plan and Proof of Publication \\
\hline Proposed Revision & In paragraph two, after Erosion Control Plan add: \\
& Stormwater Pollution Prevention Plan (SWPPP) \\
\hline
\end{tabular}




\section{Part V - Water Quality \& SWPPP}

\begin{tabular}{|l|l|}
\hline Document & INDOT Design Manual \\
\hline Reference Chapter & Chapter 36- Pavement/Storm Drainage Systems \\
\hline Reference Section & 36-2.02 Bridge Decks \\
\hline Proposed Revision & $\begin{array}{c}\text { Add the following paragraph at the end of this section: } \\
\text { The appropriate water quality parameter, either water quality volume or water } \\
\text { quality treatment rate, should be determined for use in the design of } \\
\text { stormwater treatment BMPs. Refer to Section 29-12.0 for water quality } \\
\text { calculations related to hydrology. }\end{array}$ \\
\hline
\end{tabular}

\begin{tabular}{|c|c|}
\hline Document & INDOT Design Manual \\
\hline Reference Chapter & Chapter 36 - Pavement/Storm Drainage Systems \\
\hline Reference Section & 36-2.15 NEW SECTION \\
\hline Proposed Revision & $\begin{array}{l}\text { - Add the following section: } \\
\text { 36-2.15 Stormwater Quality Design } \\
\text { Due to the area impacted within the construction limits, Stormwater Pollution } \\
\text { Prevention (SWPPP) BMPS are needed for virtually all INDOT projects, as } \\
\text { defined in Section 9-1.02. BMPs can be incorporated into inlets, manholes, } \\
\text { ditches, swales, and storage facilities. The pollution prevention BMP system } \\
\text { should be designed such that approximately } 80 \% \text { of the average annual post- } \\
\text { development total suspended solids (TSS) load is removed from the runoff. } \\
\text { The designer should attempt to minimize the overall number of BMPs, in } \\
\text { order to reduce cost and maintenance needs. Section } 39 \text { describes specific } \\
\text { types and applications of post-construction stormwater pollution prevention } \\
\text { BMPS. }\end{array}$ \\
\hline
\end{tabular}

\begin{tabular}{|l|c|}
\hline Document & INDOT Design Manual \\
\hline Reference Chapter & Chapter 36 - Pavement/Storm Drainage Systems \\
\hline Reference Section & 36-5.04 Preliminary Sketch \\
\hline Proposed Revision & $\bullet \quad$ Add water quality features to the list of items to include in the preliminary sketch. \\
\hline
\end{tabular}

\begin{tabular}{|l|l|}
\hline Document & INDOT Design Manual \\
\hline Reference Chapter & Chapter 36- Pavement/Storm Drainage Systems \\
\hline Reference Section & $\begin{array}{c}\text { 36-12.02 Design Procedures } \\
\text { Proposed Revision }\end{array}$ \\
$\begin{array}{l}\text { Add the following paragraph as item 4 on the list of operations for the design of } \\
\text { storm drainage systems. Renumber the other items accordingly. }\end{array}$ \\
$\begin{array}{l}\text { Calculate the appropriate water quality parameter, either water quality volume } \\
\text { or water quality treatment rate, for use in the design of stormwater treatment } \\
\text { BMPs. Select stormwater pollution prevention BMPs to satisfy water quality } \\
\text { requirements. Refer to Section 29-12.0 for water quality calculations related } \\
\text { to hydrology. }\end{array}$ \\
\hline
\end{tabular}




\begin{tabular}{|l|l|}
\hline Document & INDOT Design Manual \\
\hline Reference Chapter & Chapter 37 - Temporary Erosion and Sediment Control \\
\hline Reference Section & 37-1.0 GENERAL INFORMATION \\
\hline & $\begin{array}{r}\text { Add the following sentence to the end of the first paragraph: } \\
\text { All projects should be designed and constructed with the protection of water } \\
\text { quality as a goal. Projects that have land disturbance of 0.4 ha (1 acre) or } \\
\text { more are required to have a Stormwater Pollution Prevention Plan (SWPPP) } \\
\text { that includes both construction phase and post-construction phase } \\
\text { stormwater pollution prevention Best Management Practices (BMPs.) Post- } \\
\text { construction BMPs are discussed in Chapter 39. }\end{array}$ \\
\hline
\end{tabular}

\begin{tabular}{|l|l|}
\hline Document & INDOT Design Manual \\
\hline Reference Chapter & Chapter 30 - Channels \\
\hline Reference Section & $\begin{array}{c}30-2.03 \text { INDOT Policy } \\
\text { Proposed Revision }\end{array}$ \\
\hline
\end{tabular}

\begin{tabular}{|c|c|}
\hline Document & INDOT Design Manual \\
\hline Reference Chapter & Chapter 30 - Channels \\
\hline Reference Section & 30-3.03(01) General \\
\hline Proposed Revision & $\begin{array}{l}\text { - Add the following items as point number } 4 \text { on the list of general criteria that apply } \\
\text { to roadside channels (side ditches): } \\
\text { 4. Water quality considerations to address stormwater pollution prevention } \\
\text { can be incorporated into roadside channels. Roadside channels can act as } \\
\text { water quality swales to store the water quality volume or can have off-line } \\
\text { diversion structures, such as infiltration trenches or hydrodynamic separators } \\
\text { integrated into their design. Refer to section } 39 \text { for specific types and } \\
\text { applications of post-construction stormwater pollution prevention BMPs. }\end{array}$ \\
\hline
\end{tabular}

\begin{tabular}{|l|l|}
\hline Document & INDOT Design Manual \\
\hline Reference Chapter & Chapter 30 - Channels \\
\hline Reference Section & 30-3.04 Drainage Ditches \\
\hline Proposed Revision & $\begin{array}{l}\text { Add the following items as point number } 4 \text { on the list of criteria that apply to } \\
\text { drainage ditches: }\end{array}$ \\
& $\begin{array}{l}\text { 4. Water quality considerations to address stormwater pollution prevention } \\
\text { can be incorporated into drainage ditches. Drainage ditches can store the full } \\
\text { water quality volume or can have off-line diversion structures, such as } \\
\text { infiltration trenches or hydrodynamic separators integrated into their design. } \\
\text { Refer to Section 39 for specific types and applications of post-construction } \\
\text { stormwater pollution prevention BMPs. }\end{array}$ \\
\hline
\end{tabular}




\begin{tabular}{|c|c|}
\hline Document & INDOT Design Manual \\
\hline Reference Chapter & Chapter 33 - Bridge Deck Drainage \\
\hline Reference Section & 33-2.0 System Components \\
\hline Proposed Revision & $\begin{array}{l}\text { - Modify the first sentence to read: } \\
\text { The bridge deck drainage system includes the bridge deck itself, bridge } \\
\text { gutters, inlets, pipes, downspouts, and stormwater pollution prevention } \\
\text { controls. }\end{array}$ \\
\hline
\end{tabular}

\begin{tabular}{|c|c|}
\hline Document & INDOT Design Manual \\
\hline Reference Chapter & Chapter 33 - Bridge Deck Drainage \\
\hline Reference Section & 33-2.01(06) NEW SECTION \\
\hline Proposed Revision & $\begin{array}{l}\text { - Add the following as section 33-2.01(06) as a system component of bridge deck } \\
\text { drainage: } \\
\text { 33-2.01(06) Stormwater Pollution Prevention Controls } \\
\text { Stormwater pollution prevention controls (BMPs) should be designed to provide an } \\
\text { average annual post-development TSS removal rate of } 80 \% \text {. All stormwater controls } \\
\text { must meet other design criteria listed in this section. Controls should not increase the } \\
\text { spread of water into traffic lanes, function properly with minimum maintenance, and } \\
\text { not interfere with the structural integrity of the bridge. Bridge design with downspouts } \\
\text { should not be allowed to discharge untreated flow, unless such discharge is collected } \\
\text { and treated on the receiving body beneath the bridge. No direct discharge of } \\
\text { untreated stormwater runoff is allowed. Flow consolidation should be considered to } \\
\text { reduce the number of multiple BMP installations and maintenance requirements. }\end{array}$ \\
\hline
\end{tabular}

\begin{tabular}{|c|c|}
\hline Document & INDOT Design Manual \\
\hline Reference Chapter & Chapter 39 - Post-Construction Stormwater BMPs \\
\hline Reference Section & Recommended New Chapter \\
\hline Proposed Revision & $\begin{array}{l}\text { - The Post-Construction Stormwater BMPs chapter should include the definition, } \\
\text { BMP selection process, and design criteria for INDOT approved stormwater } \\
\text { pollution prevention BMPs. This study suggests the following stormwater BMPs } \\
\text { that can be implemented to satisfy INDOT's post-construction water quality } \\
\text { requirements. Other BMPs can and should be added to this list in the future as } \\
\text { new technologies of management practices are developed. } \\
\text { 1. Wet Pond } \\
\text { 2. Extended Detention Pond } \\
\text { 3. Dry Pond } \\
\text { 4. Dry Swale } \\
\text { 5. Stormwater Wetland } \\
\text { 6. Wet Swale } \\
\text { 7. Infiltration Trench } \\
\text { 8. Infiltration Basin } \\
\text { 9. Bioretention } \\
\text { 10. Filter Strip } \\
\text { 11. Water Quality Structures }\end{array}$ \\
\hline
\end{tabular}




\begin{tabular}{|l|l|}
\hline Document & INDOT Standard Drawings \\
\hline Reference Location & Section 726 - Water Quality structures (NEW STANDARD DRAWING SECTION) \\
\hline Reference Drawing & General Comment \\
\hline Code Meaning & General Comment \\
\hline Drawing Title & General Comment \\
\hline Proposed Revision & $\begin{array}{l}\text { Another proprietary structural BMP is a catch basin insert. Catch basin inserts } \\
\text { come in many forms. Manufacturers will often have different systems based on } \\
\text { the pollutant being targeted, for example, oil and grease versus sediment and oil } \\
\text { and grease. The primary concern with the performance of catch basin inserts is } \\
\text { maintenance. The actual maintenance of catch basin inserts is easy. The } \\
\text { difficulty is the frequency of maintenance that may be required due to limited } \\
\text { sediment storage. In addition, catch basin inserts are located "out of sight" and } \\
\text { can easily be forgotten about. Because of this, it is recommended that INDOT } \\
\text { consider the use of catch basin inserts only when other BMP methods are not } \\
\text { feasible or practical (one such potential area would on bridge decks). It is } \\
\text { therefore recommended that INDOT not make a Standard Drawing for this } \\
\text { measure, as it would only encourage its use in inappropriate locations, increasing } \\
\text { the maintenance burden on INDOT staff. }\end{array}$ \\
\hline
\end{tabular}

\begin{tabular}{|l|l|}
\hline Document & INDOT Standard Drawings \\
\hline Reference Location & Section 726 - Water Quality structures (NEW STANDARD DRAWING SECTION) \\
\hline Reference Drawing & General Comment \\
\hline Code Meaning & General Comment \\
\hline Drawing Title & General Comment \\
\hline & $\begin{array}{l}\text { INDOT may also wish to create Standard Drawings for other post-construction } \\
\text { stormwater pollution prevention BMPs that are approved for use on INDOT } \\
\text { projects. Some of the potential BMPs, such as stormwater wetlands, detention } \\
\text { and retention facilities, bioretention areas, filter strips, and water quality swales } \\
\text { can be constructed of materials and specifications that are already a part of the } \\
\text { INDOT Standard Specifications; therefore an independent Standard Drawing may } \\
\text { not be required. The Designer should refer to BMP Fact Sheets for specific } \\
\text { design information. These figures should be located in the Design Manuals, not } \\
\text { the Standard Drawings. }\end{array}$ \\
\hline
\end{tabular}




\begin{tabular}{|l|l|l|}
\hline Document & INDOT Standard Specifications \\
\hline Reference Location & SECTION 100 - GENERAL PROVISIONS \\
\hline Reference Location & SECTION 108 - PROSECUTION AND PROGRESS \\
\hline Reference Location & 108.04 Prosecution of Work \\
\hline & $\begin{array}{l}\text { Modify the ninth paragraph to state: } \\
\text { The Contractor is legally responsible for adhering to and amending the } \\
\text { SWPPP, including maintenance or stormwater pollution prevention } \\
\text { measures. An amended SWPPP shall be submitted to the designated } \\
\text { stormwater pollution prevention review entity in accordance with the NPDES } \\
\text { Phase II permit for those areas not included in the Department submittal or } \\
\text { as necessary for changes initiated by the Contractor. Items to include consist } \\
\text { of sequencing of operations, borrow and disposal areas, and haul roads as } \\
\text { well as any revision to the Department's submittal. Borrow and disposal } \\
\text { areas may require a separate SWPPP as determined by the reviewing } \\
\text { authority. All appropriate perimeter protection erosion control items shall be } \\
\text { in place prior to disturbing the project site. A copy of the amended plan shall } \\
\text { be provided to the Department and the Engineer. } \\
\text { Add the following sentence to the end of point (d) in the eleventh paragraph: } \\
\text { (d)...The Contractor shall follow the Spill Prevention and Response } \\
\text { procedures described in the project SWPPP. In the event no procedures are } \\
\text { outlined, the Contractor shall amend SWPPP with the appropriate project- } \\
\text { specific procedures. These procedures should be applied to all stored } \\
\text { chemicals or fuels. }\end{array}$ \\
\hline
\end{tabular}

\begin{tabular}{|c|c|}
\hline Document & INDOT Standard Specifications \\
\hline Reference Location & SECTION 100 - GENERAL PROVISIONS \\
\hline Reference Location & SECTION 108 - PROSECUTION AND PROGRESS \\
\hline Reference Location & 108.11 Termination of Contractor's Responsibility \\
\hline Proposed Revision & $\begin{array}{l}\text { - Add the following item as point (h): } \\
\text { (h) when the Contractor is unable or unwilling to update and adhere to the } \\
\text { approved SWPPP and the requirements of the approved NPDES Phase II } \\
\text { permit, including but not limited to maintenance of erosion and sediment } \\
\text { control measures for stormwater pollution prevention. }\end{array}$ \\
\hline
\end{tabular}

\begin{tabular}{|l|l|}
\hline Document & INDOT Standard Specifications \\
\hline Reference Location & SECTION 100 - GENERAL PROVISIONS \\
\hline Reference Location & SECTION 108- PROSECUTION AND PROGRESS \\
\hline Reference Location & \begin{tabular}{c} 
108.12 Contract Documentation \\
\hline Proposed Revision
\end{tabular} \\
$\begin{array}{c}\text { Add the following item at the end of the paragraph as documentation the } \\
\text { contractor should have available and be able to furnish upon request: } \\
\text { Modifications or amendments to the SWPPP, SWPPP for disposal or borrow } \\
\text { sites as required, and erosion and sediment control measure (BMP) } \\
\text { inspection forms. The Contractor shall maintain such records for a period no } \\
\text { less than three years from the date of the NOT. }\end{array}$ \\
\hline
\end{tabular}




\begin{tabular}{|l|l|}
\hline Document & INDOT Standard Specifications \\
\hline Reference Location & SECTION 200 - EARTHWORK \\
\hline Reference Location & SECTION 203 - EXCAVATION AND EMBANKMENT \\
\hline Reference Location & \begin{tabular}{c}
203.08 Borrow or Disposal \\
\hline Proposed Revision
\end{tabular} \\
$\begin{array}{r}\text { Modify point (c) to state: } \\
\text { (c) an amended or separate SWPPP in accordance with the requirements of } \\
\text { the NPDES Phase II permit submitted to the designated stormwater pollution } \\
\text { prevention review authority (if not previously developed and approved); }\end{array}$ \\
\hline
\end{tabular}

\begin{tabular}{|l|l|}
\hline Document & INDOT Standard Specifications \\
\hline Reference Location & SECTION 200-EARTHWORK \\
\hline Reference Location & SECTION 205 - TEMPORARY EROSION AND SEDIMENT CONTROL \\
\hline Reference Location & 205.03 Control Measures \\
\hline & $\begin{array}{c}\text { Add the following at the end of the first paragraph in section 205.03(n) Retention } \\
\text { Ponds: }\end{array}$ \\
Proposed Revision & $\begin{array}{l}\text { If retention facilities are used as temporary sediment traps during } \\
\text { construction, accumulated sediment shall be removed prior to the final } \\
\text { acceptance of the project. }\end{array}$ \\
\hline
\end{tabular}

\begin{tabular}{|l|l|}
\hline Document & INDOT Standard Specifications \\
\hline Reference Location & SECTION 200 - EARTHWORK \\
\hline Reference Location & SECTION 205 - TEMPORARY EROSION AND SEDIMENT CONTROL \\
\hline Reference Location & \begin{tabular}{l} 
205.03 Control Measures \\
\hline Proposed Revision
\end{tabular} \\
$\begin{array}{c}\text { Add the following as new section 205.03(r) Concrete Washout Area: } \\
\text { (r) Concrete Washout Area. Concrete washout areas shall be constructed } \\
\text { as shown on the plans. Concrete washout shall be limited to the location } \\
\text { shown on the plans. }\end{array}$ \\
\hline
\end{tabular}

\begin{tabular}{|l|l|}
\hline Document & INDOT Standard Specifications \\
\hline Reference Location & SECTION 200 - EARTHWORK \\
\hline Reference Location & SECTION 205-TEMPORARY EROSION AND SEDIMENT CONTROL \\
\hline Reference Location & \begin{tabular}{c} 
Mo5.04 Maintenance \\
\hline
\end{tabular} \\
Proposed Revision & $\begin{array}{c}\text { M..Contractor at a minimum once every } 7 \text { days and after rain activities totaling } \\
1 / 2 \text { inch of rainfall in a } 24 \text { hour period. The Contractor shall install and keep a } \\
\text { rain gauge in an unobstructed area on the project site for measuring daily } \\
\text { rainfall accumulation. The daily rainfall totals should be recorded in the } \\
\text { project documentation. }\end{array}$ \\
\hline
\end{tabular}




\begin{tabular}{|l|c|}
\hline Document & INDOT Standard Specifications \\
\hline Reference Location & SECTION 200 - EARTHWORK \\
\hline Reference Location & SECTION 215 - CHEMICAL MODIFICATION OF SOILS \\
\hline Reference Location & 215.04 Storage and Handling \\
\hline Proposed Revision & $\begin{array}{l}\text { Although it has already been included as a recommended change for Section } \\
108.03, \text { the Spill Prevention and Response plan included in the SWPPP should } \\
\text { be followed for all chemicals stored on the project site. It may also be appropriate } \\
\text { to restate this in Section 215.04. }\end{array}$ \\
\hline
\end{tabular}

\begin{tabular}{|c|c|}
\hline Document & INDOT Standard Specifications \\
\hline Reference Location & SECTION 400 - ASPHALT PAVEMENT \\
\hline Reference Location & $\begin{array}{l}\text { SECTION } 404 \text { SEAL COAT, SECTION } 405 \text { PRIME COAT, SECTION } 406 \text { TACK COAT, } \\
\text { and SECTION } 408 \text { SEALING CRACKS AND JOINTS. }\end{array}$ \\
\hline Reference Location & General \\
\hline Proposed Revision & $\begin{array}{l}\text { - Although it has already been included as a recommended change for Section } \\
108.03 \text {, the Spill Prevention and Response plan included in the SWPPP should } \\
\text { be followed for all chemicals stored on the project site, including those used for } \\
\text { asphalt paving or batching operations. It may also be appropriate to restate this } \\
\text { in Sections } 404,405,406 \text {, and } 408 \text {. }\end{array}$ \\
\hline
\end{tabular}

\begin{tabular}{|l|l|}
\hline Document & INDOT Standard Specifications \\
\hline Reference Location & SECTION 500-CONCRETE PAVEMENT \\
\hline Reference Location & General \\
\hline Reference Location & General \\
\hline Proposed Revision & $\begin{array}{l}\text { Although it has already been included as a recommended change for Section } \\
108.03, \text { the Spill Prevention and Response plan included in the SWPPP should } \\
\text { be followed for all chemicals stored on the project site, including those used for } \\
\text { concrete paving, batching operations, curing, or sealing. Suggested revisions to } \\
\text { Section 205.03 include a provision for limiting concrete washout. It may be } \\
\text { appropriate to restate these provisions in Section 500. }\end{array}$ \\
\hline
\end{tabular}




\section{Part VI - Miscellaneous Recommendations}

\begin{tabular}{|c|c|}
\hline Document & INDOT Design Manual \\
\hline Reference Chapter & Chapter 29 - Hydrology \\
\hline Reference Section & Table of Contents \\
\hline Proposed Revision & $\begin{array}{l}\text { Add the following sections: } \\
\text { 29-12.0 HYDROLOGY CALCULATIONS FOR WATER QUALITY } \\
\text { 29-12.1 Water Quality Volume Calculation } \\
\text { 29-12.2 Water Quality Treatment Rate Calculation } \\
\text { - Renumber section 29-12.0 REFERENCES to 29-13.0 REFERENCES }\end{array}$ \\
\hline
\end{tabular}

\begin{tabular}{|l|l|}
\hline Document & INDOT Design Manual \\
\hline Reference Chapter & Chapter 29 - Hydrology \\
\hline Reference Section & 29-12.0 NEW SECTION \\
\hline Proposed Revision & $\bullet \quad$ Renumber Section 29-12.0 REFERENCES to 29-13.0 REFERENCES \\
\hline
\end{tabular}

\begin{tabular}{|l|c|}
\hline Document & INDOT Design Manual \\
\hline Reference Chapter & Chapter 37 - Temporary Erosion and Sediment Control \\
\hline Reference Section & $\begin{array}{r}\text { 37-2.0 SITE ANALYSIS } \\
\hline \text { Proposed Revision }\end{array}$ \\
& $\begin{array}{l}\text { Add "soil types" to the list of items in the second paragraph the designer should } \\
\text { look at during a site analysis. }\end{array}$ \\
& Add "and soil types." to the last sentence of the second paragraph. \\
\hline
\end{tabular}

\begin{tabular}{|c|c|}
\hline Document & INDOT Design Manual \\
\hline Reference Chapter & Chapter 85 - Right-Of-Way Plan Preparation \\
\hline Reference Section & GENERAL COMMENT \\
\hline Proposed Revision & $\begin{array}{l}\text { - While modifications to other INDOT Designer Manual sections have addressed } \\
\text { that new designs shall incorporate post-construction stormwater pollution } \\
\text { prevention BMPs, additional right-of-way needs that may be required should be } \\
\text { considered by the designer and checked by the INDOT review consultant. }\end{array}$ \\
\hline
\end{tabular}

\begin{tabular}{|l|c|}
\hline Reference Location & SECTION 600 - INCIDENTAL CONSTRUCTION \\
\hline Reference Location & SECTION 621 - SEEDING AND SODDING \\
\hline Reference Location & 621.05 Applying Fertilizer, Seed, and Mulch \\
\hline Proposed Revision & $\begin{array}{l}\text { It is recommended that for }(d) \text { Excelsior Blankets, (e) Paper Mats, and (f) Straw } \\
\text { Mat, the text be changed to state the anchoring, overlapping, and staple patterns } \\
\text { used to install and secure the respective erosion control blankets be completed by } \\
\text { following the most recent manufacturer installation guidelines based on slope, } \\
\text { particular material and application. }\end{array}$ \\
\hline
\end{tabular}




\begin{tabular}{|l|c|}
\hline Document & INDOT Standard Specifications \\
\hline Reference Location & SECTION 600 - INCIDENTAL CONSTRUCTION \\
\hline Reference Location & SECTION 622 - PLANTING TREES, SHRUBS, AND VINES \\
\hline Reference Location & \begin{tabular}{l}
622.02 Materials, General Comments \\
\hline Proposed Revision
\end{tabular} $\begin{array}{l}\text { INDOT should perform a review of all their tree, shrub, and vine types to ensure } \\
\text { that species know to be noxious or invasive in the State of Indiana are not } \\
\text { recommended. Some references list crown vetch in the list of species invasive to } \\
\text { the State of Indiana. }\end{array}$ \\
\hline
\end{tabular}

\begin{tabular}{|l|c|}
\hline Document & $\begin{array}{l}\text { Erosion Control Technology Council (ECTC) Department of Transportation Training } \\
\text { Courses }\end{array}$ \\
\hline Reference Location & General Comment \\
\hline Reference Location & General Comment \\
\hline Proposed Revision & $\begin{array}{l}\text { The Erosion Control Technology Council offers two courses to DOTs in the United } \\
\text { States and Canada. The first course is a two hour introductory that covers broad } \\
\text { topics such as designing with rolled erosion control products (RECP), installation } \\
\text { on RECPs, and how to use the ECTC website to evaluate products. The second } \\
\text { course is a full day seminar that takes an in-depth look at regulations, structural } \\
\text { and non-structural erosion and sediment control measures, and selection, design, } \\
\text { installation, and inspection of RECPs. } \\
\text { These courses are offered at nearly a 75\% discount to DOTs. INDOT may want } \\
\text { to further investigate the training opportunity. }\end{array}$ \\
\hline
\end{tabular}




\section{Supporting Documentation}




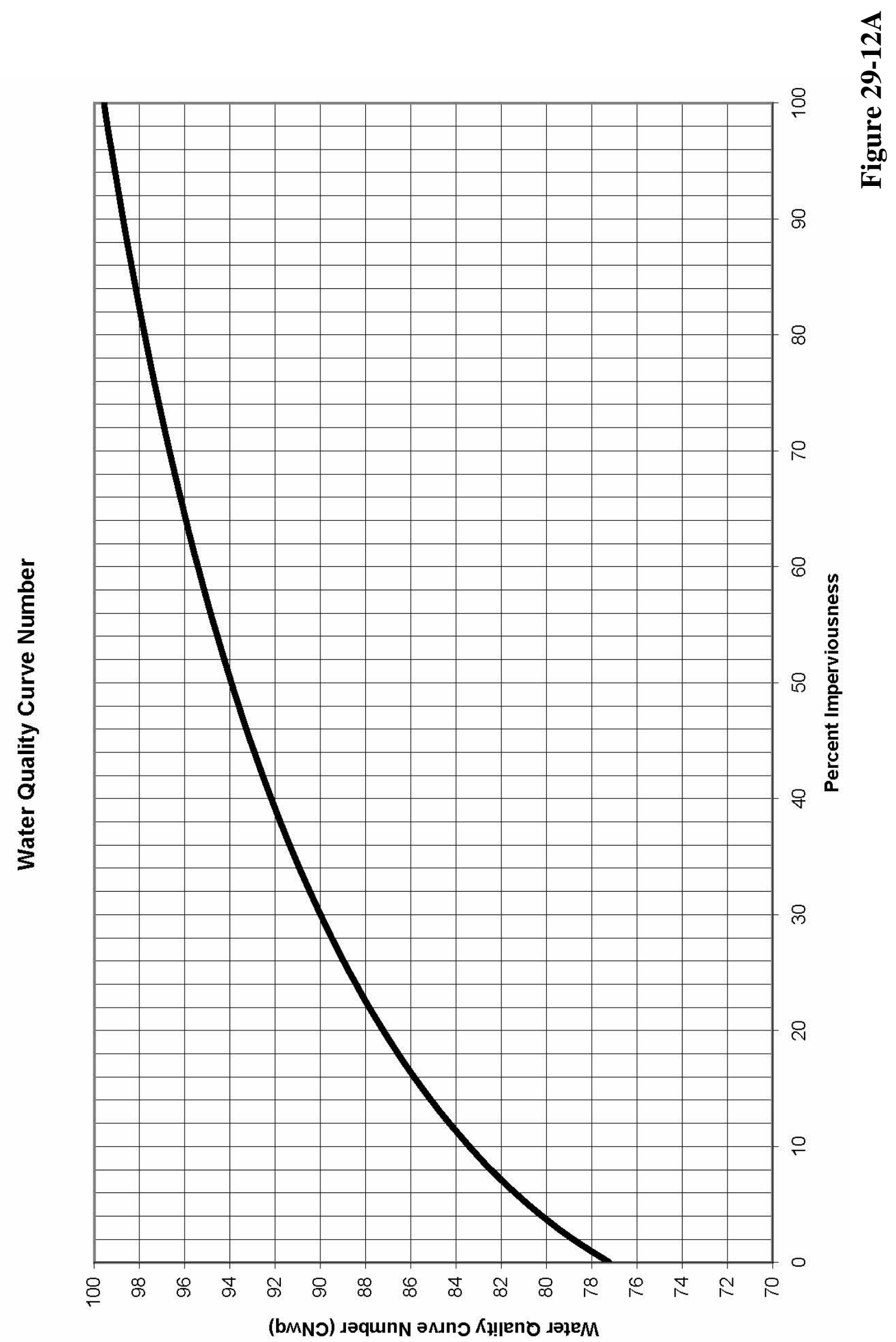


Figure 9-2: Indiana SWCD Contact Number by County

\section{Indiana Soil and Water Conservation Districts Contact Numbers by County}

\begin{tabular}{|c|c|c|c|}
\hline $\begin{array}{c}\text { Adams Co. SWCD } \\
\text { (219) 724-3763 }\end{array}$ & $\begin{array}{l}\text { Franklin Co. SWCD } \\
\text { (765) 647-2651 }\end{array}$ & $\begin{array}{c}\text { Lawrence Co. SWCD } \\
\text { (812) } 279-8117\end{array}$ & $\begin{array}{l}\text { Rush Co. SWCD } \\
\text { (765) } 932-2813\end{array}$ \\
\hline $\begin{array}{l}\text { Allen Co. SWCD } \\
(219) 426-4637\end{array}$ & $\begin{array}{c}\text { Fulton Co. SWCD } \\
\text { (219) 223-3220 }\end{array}$ & $\begin{array}{l}\text { Madison Co. SWCD } \\
\text { (765) } 644-4249\end{array}$ & $\begin{array}{c}\text { Scott Co. SWCD } \\
\text { (812) } 752-2269\end{array}$ \\
\hline $\begin{array}{l}\text { Bartholomew Co. SWCD } \\
\text { (812) } 378-1280\end{array}$ & $\begin{array}{l}\text { Gibson Co. SWCD } \\
\text { (812) } 385-5033\end{array}$ & $\begin{array}{l}\text { Marion Co. SWCD } \\
\quad(317) 780-1765\end{array}$ & $\begin{array}{c}\text { Shelby Co. SWCD } \\
\text { (317) 392-1394 }\end{array}$ \\
\hline $\begin{array}{l}\text { Benton Co. SWCD } \\
\text { (765) } 884-1090\end{array}$ & $\begin{array}{l}\text { Grant Co. SWCD } \\
\text { (765) } 668-8985\end{array}$ & $\begin{array}{l}\text { Marshall Co. SWCD } \\
\text { (219) 936-2024 }\end{array}$ & $\begin{array}{l}\text { Spencer Co. SWCD } \\
\text { (812) 649-9136 }\end{array}$ \\
\hline $\begin{array}{l}\text { Blackford Co. SWCD } \\
\text { (765) } 348-1404\end{array}$ & $\begin{array}{l}\text { Greene Co. SWCD } \\
\text { (812) } 384-4781\end{array}$ & $\begin{array}{l}\text { Martin Co. SWCD } \\
\text { (812) } 247-2423\end{array}$ & $\begin{array}{l}\text { Starke Co SWCD } \\
(219) 772-3066\end{array}$ \\
\hline $\begin{array}{l}\text { Boone Co. SWCD } \\
\text { (765) } 482-6355\end{array}$ & $\begin{array}{l}\text { Hamilton Co. SWCD } \\
\text { (317) } 773-2181\end{array}$ & $\begin{array}{l}\text { Miami Co. SWCD } \\
\text { (765) } 473-6753\end{array}$ & $\begin{array}{l}\text { Steuben Co. SWCD } \\
\text { (219) 665-3211 }\end{array}$ \\
\hline $\begin{array}{l}\text { Brown Co. SWCD } \\
\text { (812) } 988-2211\end{array}$ & $\begin{array}{l}\text { Hancock Co. SWCD } \\
\text { (317) } 462-2283\end{array}$ & $\begin{array}{l}\text { Monroe Co. SWCD } \\
\text { (812) } 349-2046\end{array}$ & $\begin{array}{c}\text { St. Joseph Co. SWCD } \\
\text { (219) } 291-2300\end{array}$ \\
\hline $\begin{array}{l}\text { Carroll Co. SWCD } \\
\text { (765) 564-4480 }\end{array}$ & $\begin{array}{l}\text { Harrison Co. SWCD } \\
(812) 738-8124\end{array}$ & $\begin{array}{c}\text { Montgomery Co. SWCD } \\
\text { (765) 362-1194 }\end{array}$ & $\begin{array}{l}\text { Sullivan Co. SWCD } \\
\text { (812) } 268-5157\end{array}$ \\
\hline $\begin{array}{l}\text { Cass Co. SWCD } \\
(219) 753-4705\end{array}$ & $\begin{array}{l}\text { Hendricks Co. SWCD } \\
\text { (317) } 745-2555\end{array}$ & $\begin{array}{l}\text { Morgan Co. SWCD } \\
\text { (765) } 342-5594\end{array}$ & $\begin{array}{c}\text { Switzerland Co. SWCD } \\
\text { (812) } 427-3126\end{array}$ \\
\hline $\begin{array}{l}\text { Clark Co. SWCD } \\
\text { (812) } 256-2330\end{array}$ & $\begin{array}{l}\text { Henry Co. SWCD } \\
\text { (765) } 529-2303\end{array}$ & $\begin{array}{l}\text { Newton Co. SWCD } \\
\text { (219) 285-6889 }\end{array}$ & $\begin{array}{l}\text { Tippecanoe Co. SWCD } \\
\text { (765) } 448-1805\end{array}$ \\
\hline $\begin{array}{l}\text { Clay Co. SWCD } \\
(812) 448-1108\end{array}$ & $\begin{array}{l}\text { Howard Co. SWCD } \\
\text { (765) 457-2114 }\end{array}$ & $\begin{array}{l}\text { Noble Co. SWCD } \\
\text { (219) 636-7682 }\end{array}$ & $\begin{array}{l}\text { Tipton Co. SWCD } \\
\text { (765) } 675-2316\end{array}$ \\
\hline $\begin{array}{l}\text { Clinton Co. SWCD } \\
\text { (765) 659-1223 }\end{array}$ & $\begin{array}{l}\text { Huntington Co. SWCD } \\
\text { (219) } 356-6816\end{array}$ & $\begin{array}{l}\text { Ohio Co. SWCD } \\
(812) 438-1241\end{array}$ & $\begin{array}{l}\text { Union Co. SWCD } \\
\text { (765) } 825-4311\end{array}$ \\
\hline $\begin{array}{c}\text { Crawford Co. SWCD } \\
\text { (812) 338-3224 }\end{array}$ & $\begin{array}{c}\text { Jackson Co. SWCD } \\
(812) 358-2367\end{array}$ & $\begin{array}{c}\text { Orange Co. SWCD } \\
(812) 723-3311\end{array}$ & $\begin{array}{c}\text { Vanderburgh Co. SWCD } \\
\text { (812) 867-0729 }\end{array}$ \\
\hline $\begin{array}{l}\text { Daviess Co. SWCD } \\
\text { (812) } 254-4780\end{array}$ & $\begin{array}{c}\text { Jasper Co. SWCD } \\
(219) 866-8008\end{array}$ & $\begin{array}{l}\text { Owen Co. SWCD } \\
\text { (812) 829-2605 }\end{array}$ & $\begin{array}{c}\text { Vermillion Co. SWCD } \\
\text { (765) 492-3705 }\end{array}$ \\
\hline $\begin{array}{l}\text { Dearborn Co. SWCD } \\
\text { (812) 926-2406 }\end{array}$ & $\begin{array}{l}\text { Jay Co. SWCD } \\
(219) 726-4373\end{array}$ & $\begin{array}{l}\text { Parke Co. SWCD } \\
\text { (765) } 569-3551\end{array}$ & $\begin{array}{l}\text { Vigo Co. SWCD } \\
(812) 232-0193\end{array}$ \\
\hline $\begin{array}{l}\text { Decatur Co. SWCD } \\
\text { (812) 663-8685 }\end{array}$ & $\begin{array}{c}\text { Jefferson Co. SWCD } \\
\text { (812) 273-2070 }\end{array}$ & $\begin{array}{l}\text { Perry Co. SWCD } \\
\text { (812) } 547-4686\end{array}$ & $\begin{array}{l}\text { Wabash Co. SWCD } \\
\text { (219) 563-7486 }\end{array}$ \\
\hline $\begin{array}{l}\text { DeKalb Co. SWCD } \\
\text { (219) 925-5620 }\end{array}$ & $\begin{array}{c}\text { Jennings Co. SWCD } \\
\text { (812) } 346-3411\end{array}$ & $\begin{array}{l}\text { Pike Co. SWCD } \\
(812) 354-6120\end{array}$ & $\begin{array}{l}\text { Warren Co. SWCD } \\
\text { (765) } 762-2443\end{array}$ \\
\hline $\begin{array}{c}\text { Delaware Co. SWCD } \\
\text { (765) } 747-5531\end{array}$ & $\begin{array}{l}\text { Johnson Co. SWCD } \\
\text { (317) } 736-9540\end{array}$ & $\begin{array}{l}\text { Porter Co. SWCD } \\
\text { (219) } 464-1049\end{array}$ & $\begin{array}{l}\text { Warrick Co. SWCD } \\
\quad(812) 897-2840\end{array}$ \\
\hline $\begin{array}{c}\text { Dubois Co. SWCD } \\
\text { (812) } 482-1171\end{array}$ & $\begin{array}{c}\text { Knox Co. SWCD } \\
\text { (812) } 882-8210\end{array}$ & $\begin{array}{l}\text { Posey Co. SWCD } \\
\text { (812) 838-4191 }\end{array}$ & $\begin{array}{c}\text { Washington Co. SWCD } \\
(812) 883-3704\end{array}$ \\
\hline $\begin{array}{l}\text { Elkhart Co. SWCD } \\
\text { (219) } 533-3630\end{array}$ & $\begin{array}{c}\text { Kosciusko Co. SWCD } \\
\text { (219) } 267-7445\end{array}$ & $\begin{array}{l}\text { Pulaski Co. SWCD } \\
\text { (219) } 946-3243\end{array}$ & $\begin{array}{l}\text { Wayne Co. SWCD } \\
\text { (765) 966-0191 }\end{array}$ \\
\hline $\begin{array}{c}\text { Fayette Co. SWCD } \\
\text { (765) 825-4311 }\end{array}$ & $\begin{array}{c}\text { LaGrange Co. SWCD } \\
\text { (219) } 463-3471\end{array}$ & $\begin{array}{l}\text { Putnam Co. SWCD } \\
\text { (765) } 653-7454\end{array}$ & $\begin{array}{l}\text { Wells Co. SWCD } \\
\text { (219) } 824-1930\end{array}$ \\
\hline $\begin{array}{l}\text { Floyd Co. SWCD } \\
\text { (812) } 945-9936\end{array}$ & $\begin{array}{l}\text { Lake Co. SWCD } \\
(219) 663-0588\end{array}$ & $\begin{array}{l}\text { Randolph Co. SWCD } \\
\text { (765) 584-4505 }\end{array}$ & $\begin{array}{l}\text { White Co. SWCD } \\
\text { (219) 583-5962 }\end{array}$ \\
\hline $\begin{array}{l}\text { Fountain Co. SWCD } \\
\text { (765) } 793-3651\end{array}$ & $\begin{array}{l}\text { LaPorte Co. SWCD } \\
\text { (219) } 362-6633\end{array}$ & $\begin{array}{c}\text { Ripley Co. SWCD } \\
\text { (812) } 689-6410\end{array}$ & $\begin{array}{l}\text { Whitley Co. SWCD } \\
\text { (219) 244-6266 }\end{array}$ \\
\hline
\end{tabular}




\section{Construction/Stormwater Pollution Prevention Plan Technical Review and Comment (Form 1)}

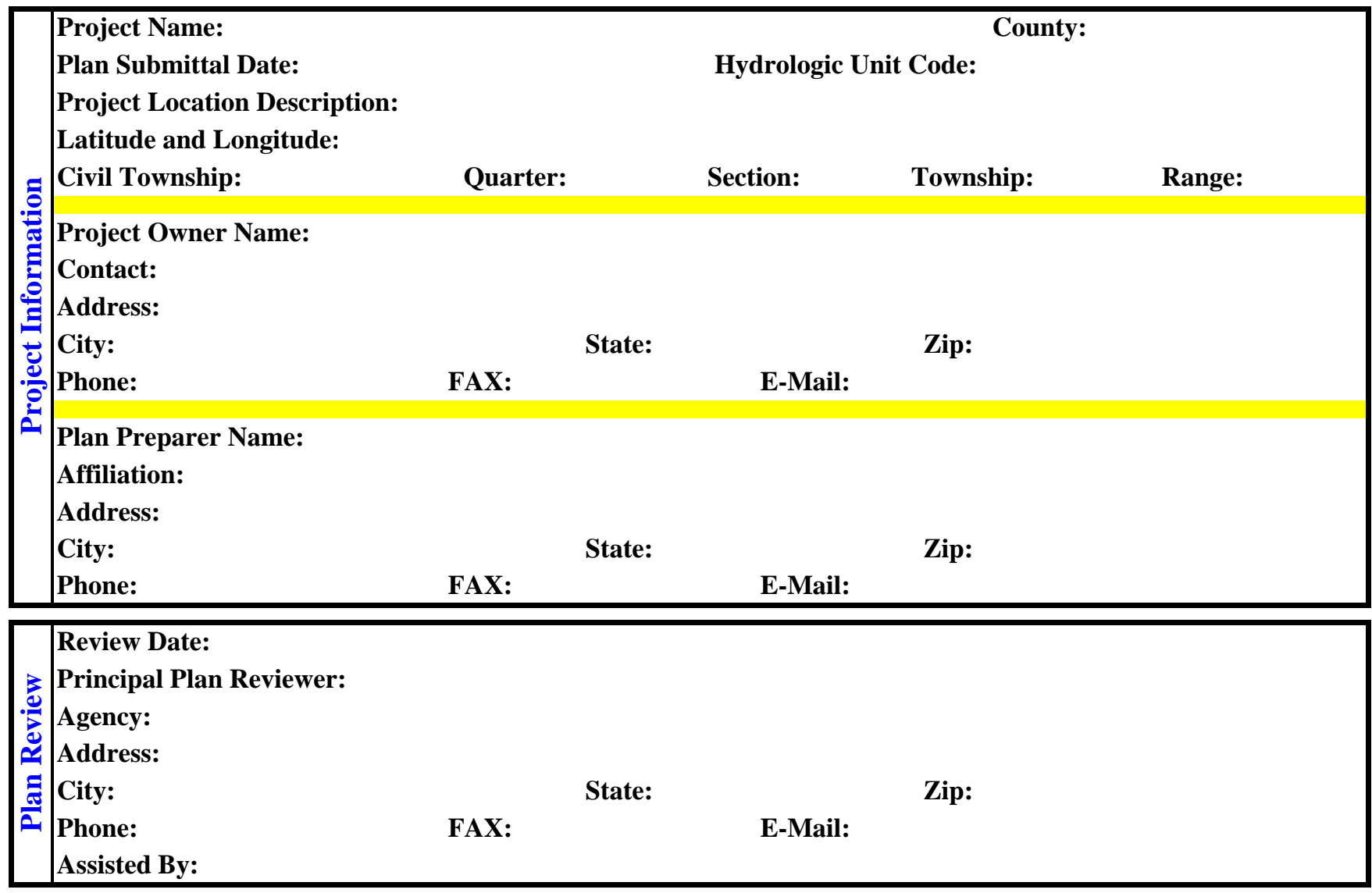

PLAN IS ADEQUATE: A comprehensive plan review has been completed and it has been determined that the plan satisfies the minimum requirements and intent of 327 IAC 15-5.

Please refer to additional information included on the following page(s).

Submit Notice of Intent (NOI): Attach a copy of this cover page when submitting the NOI to the Indiana Department of Environmental Management. Construction activities may begin 48 hours following the submittal of the NOI. A copy of the NOI must also be sent to the Reviewing Authority (e.g. SWCD, DNR).

A preliminary plan review has been completed; a comprehensive review will not be completed within the 28-day review period. The reviewing authority reserves the right to perform a comprehensive review at a later date and revisions to the plan may be required at that time to address deficiencies.

Please refer to additional information included on the following page(s).

$\square$ Submit Notice of Intent (NOI): Attach a copy of this cover page when submitting the NOI to the Indiana Department of Environmental Management. Construction activities may begin 48 hours following the submittal of the NOI. A copy of the NOI must also be sent to the Reviewing Authority (e.g. SWCD, DNR).

PLAN IS DEFICIENT: Significant deficiencies were identified during the plan review.

Please refer to additional information included on the following page(s).

DO NOT file a Notice of Intent for this project.

DO NOT commence land disturbing activities until all deficiencies are adequately addressed, the plan resubmitted, and notification has been received that the minimum requirements have been satisfied.

Plan Revisions $\square$ Deficient Items should be mailed or delivered to the Principal Plan Reviewer identified in the Plan Review Section above. 
Construction/Stormwater Pollution Prevention Plan - Technical Review and Comment (Form 1)

\author{
Project Name: 0 \\ Date Reviewed: $01 / 00 / 00$
}

The technical review and comments are intended to evaluate the completeness of the Construction/Stormwater Pollution Prevention Plan for the project. The Plan submitted was not reviewed for the adequacy of the engineering design. All measures included in the plan, as well as those recommended in the comments should be evaluated as to their feasibility by a qualified individual with structural measures designed by a qualified engineer. The Plan has not been reviewed for other local, state, or federal permits that may be required to proceed with this project. Additional information, including design calculations may be requested to further evaluate the Plan.

All proposed stormwater pollution prevention measures and those referenced in this review must meet the design criteria and standards set forth in the "Indiana Stormwater Quality Manual" from the Indiana Department of Natural Resources, Division of Soil Conservation or similar Guidance Documents.

Please direct questions and/or comments regarding this plan review to:

0

Please refer to the address and contact information identified in the Plan Review Section on page 1.

\title{
Assessment of Construction Plan Elements (Section A)
}

\section{The Construction Plan Elements are adequately represented to complete a plan review:}

\section{Yes $\square$ No}

The items checked below are deficient and require submittal to meet the requirements of the rule.

\begin{tabular}{|c|c|c|c|c|}
\hline A & & A & $\mathbf{A}$ & \\
\hline 1 & Index showing locations of required Plan Elements & $\square$ & 2 & $\begin{array}{l}11 \text { by } 17 \text { inch plat showing building lot } \\
\text { numbers/boundaries and road layout/names }\end{array}$ \\
\hline 3 & $\begin{array}{l}\text { Narrative describing the nature and purpose of the } \\
\text { project }\end{array}$ & $\square$ & 4 & Vicinity map showing project location \\
\hline 5 & $\begin{array}{l}\text { Legal Description of the Project Site } \\
\text { (Include Latitude and Longitude - NOI Requirement) }\end{array}$ & $\square$ & 6 & $\begin{array}{l}\text { Location of all lots and proposed site } \\
\text { improvements (roads, utilities, structures, etc.) }\end{array}$ \\
\hline 7 & Hydrologic unit code (14 Digit) & $\square$ & 8 & $\begin{array}{l}\text { Notation of any State or Federal water quality } \\
\text { permits }\end{array}$ \\
\hline 9 & $\begin{array}{l}\text { Specific points where stormwater discharge will leave } \\
\text { the site }\end{array}$ & $\square$ & 10 & $\begin{array}{l}\text { Location and name of all wetlands, lakes and } \\
\text { water courses on and adjacent to the site }\end{array}$ \\
\hline 11 & Identification of all receiving waters & $\square$ & 12 & $\begin{array}{l}\text { Identification of potential discharges to ground } \\
\text { water (abandoned wells, sinkholes, etc.) }\end{array}$ \\
\hline 13 & 100 year floodplains, floodways, and floodway fringes & $\square$ & 14 & $\begin{array}{l}\text { Pre-construction and post construction estimate of } \\
\text { Peak Discharge (10 Year storm event) }\end{array}$ \\
\hline 15 & Adjacent landuse, including upstream watershed & $\|$ & 16 & $\begin{array}{l}\text { Locations and approximate boundaries of all } \\
\text { disturbed areas (Construction Limits) }\end{array}$ \\
\hline 17 & Identification of existing vegetative cover & $\square$ & 18 & $\begin{array}{l}\text { Soils map including soil descriptions and } \\
\text { limitations }\end{array}$ \\
\hline 19 & $\begin{array}{l}\text { Locations, size and dimensions of proposed stormwater } \\
\text { systems (e.g. pipes, swales and channels) }\end{array}$ & 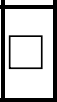 & 20 & $\begin{array}{l}\text { Plans for any off-site construction activities } \\
\text { associated with this project (sewer/water tie-ins) }\end{array}$ \\
\hline 21 & $\begin{array}{l}\text { Locations of proposed soil stockpiles and/or } \\
\text { borrow/disposal areas }\end{array}$ & $\square$ & 22 & $\begin{array}{l}\text { Existing site topography at an interval appropriate } \\
\text { to indicate drainage patterns }\end{array}$ \\
\hline 23 & $\begin{array}{l}\text { Proposed final topography at an interval appropriate to } \\
\text { indicate drainage patterns }\end{array}$ & & & \\
\hline
\end{tabular}


Construction/Stormwater Pollution Prevention Plan - Technical Review and Comment (Form 1)

\begin{tabular}{|ll}
\hline Project Name: & 0 \\
Date Reviewed: & $01 / 00 / 00$
\end{tabular}

\begin{tabular}{|c|c|c|c|c|}
\hline & & & & Assessment of Stormwater Pollution Prevention Plan (Sections $B$ \& $C$ ) \\
\hline & & & Sto & ormwater Pollution Prevention Plan - Construction Component (Section B) \\
\hline 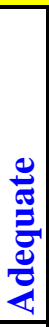 & 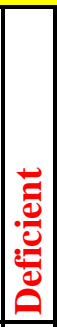 & 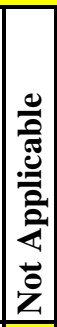 & $\mathbf{B}$ & $\begin{array}{l}\text { The construction component of the Stormwater Pollution Prevention Plan includes stormwater quality } \\
\text { measures to address erosion, sedimentation, and other pollutants associated with land disturbance and } \\
\text { construction activities. Proper implementation of the plan and inspections of the construction site are } \\
\text { necessary to minimize the discharge of pollutants. The Project Site Owner should be aware that } \\
\text { unforeseen construction activities and weather conditions may affect the performance of a practice or the } \\
\text { effectiveness of the plan. The plan must be a flexible document, with provisions to modify or substitute } \\
\text { practices as necessary. }\end{array}$ \\
\hline$\square$ & $\square$ & & 1 & Description of potential pollutant sources associated with construction activities \\
\hline$\square$ & $\square$ & & 2 & $\begin{array}{l}\text { Sequence describing stormwater quality measure implementation relative to land disturbing } \\
\text { activities }\end{array}$ \\
\hline$\square$ & $\square$ & & 3 & Stable construction entrance locations and specifications (at all points of ingress and egress) \\
\hline$\square$ & $\square$ & $\square$ & 4 & Sediment control measures for sheet flow areas \\
\hline$\square$ & $\square$ & $\square$ & 5 & Sediment control measures for concentrated flow areas \\
\hline$\square$ & $\square$ & $\square$ & 6 & Storm sewer inlet protection measure locations and specifications \\
\hline$\square$ & $\square$ & $\square$ & 7 & Runoff control measures (e.g. diversions, rock check dams, slope drains, etc .) \\
\hline$\square$ & $\square$ & $\square$ & 8 & Storm water outlet protection specifications \\
\hline$\square$ & $\square$ & $\square$ & $\overline{9}$ & Grade stabilization structure locations and specifications \\
\hline$\square$ & $\square$ & & 10 & Location, dimensions, specifications, and construction details of each stormwater quality measure \\
\hline$\square$ & $\square$ & & 11 & Temporary surface stabilization methods appropriate for each season (include sequencing) \\
\hline$\square$ & $\square$ & & 12 & Permanent surface stabilization specifications (include sequencing ) \\
\hline$\square$ & $\square$ & & 13 & Material handling and spill prevention plan \\
\hline$\square$ & $\square$ & & $\overline{14}$ & Monitoring and maintenance guidelines for each proposed stormwater quality measure \\
\hline & $\square$ & $\square$ & 15 & Erosion \& sediment control specifications for individual building lots \\
\hline & & & & awater Pollution Prevention Plan - Post Construction Component (Section C) \\
\hline 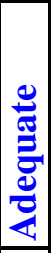 & 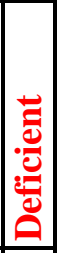 & 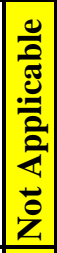 & $\mathrm{C}$ & $\begin{array}{l}\text { The post construction component of the Stormwater Pollution Prevention Plan includes the } \\
\text { implementation of stormwater quality measures to address pollutants that will be associated with the } \\
\text { final landuse. Post construction stormwater quality measures should be functional upon completion of } \\
\text { the project. Long term functionality of the measures are critical to their performance and should be } \\
\text { monitored and maintained. }\end{array}$ \\
\hline$\square$ & $\square$ & & 1 & Description of pollutants and their sources associated with the proposed land use \\
\hline$\square$ & $\square$ & & $\overline{2}$ & Sequence describing stormwater quality measure implementation \\
\hline 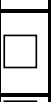 & $\square$ & & 3 & $\begin{array}{l}\text { Description of proposed post construction stormwater quality measures } \\
\text { (Include a written description of how these measures will reduce discharge of expected pollutants) }\end{array}$ \\
\hline$\square$ & $\square$ & & 4 & Location, dimensions, specifications, and construction details of each stormwater quality measure \\
\hline$\square$ & $\square$ & & 5 & Description of maintenance guidelines for post construction stormwater quality measures \\
\hline
\end{tabular}


APPENDIX 10

SUGGESTED FURTHER RESEARCH - NEW DOCUMENTS 


\begin{tabular}{|c|c|}
\hline Future Document & Contractor SWPPP Assistance Manual \\
\hline $\begin{array}{l}\text { Description and } \\
\text { Reason }\end{array}$ & $\begin{array}{l}\text { - Under new regulations, the Contractor will be required to update the SWPPP, } \\
\text { provide notification of actual work beginning dates, and to provide information to } \\
\text { INDOT as the project is finalized to attain the NOT and final payment. It is } \\
\text { anticipated that some Contractor's may need assistance in this transition period } \\
\text { - A Contractor SWPPP Assistance Manual should be developed. This document will } \\
\text { provide step-by-step instructions for the Contractor-initiated SWPPP changes that } \\
\text { are required for INDOT construction projects. In the event that the Contractor is } \\
\text { required to amend the SWPPP or develop a separate SWPPP for a borrow or } \\
\text { disposal site, they may refer to standard SWPPP details, specifications, and } \\
\text { maintenance considerations that will be included in this document. } \\
\text { This document should also contain a checklist for NOT information that must be } \\
\text { submitted by the Contractor to the Department to gain final acceptance and } \\
\text { payment. } \\
\text { This manual may also contain BMP inspection checklists and forms, maintenance } \\
\text { checklists, and a daily rainfall log form. }\end{array}$ \\
\hline
\end{tabular}

\begin{tabular}{|c|c|}
\hline Future Document & $\begin{array}{l}\text { Contractor(s) NOI Certification Statement } \\
\text { Subcontractor(s) NOI Certification Statement }\end{array}$ \\
\hline $\begin{array}{l}\text { Description and } \\
\text { Reason }\end{array}$ & $\begin{array}{l}\text { - For applicable construction projects with land disturbance activities greater than } 1 \\
\text { acre, a certification form should be developed and signed by the Contractor(s) and } \\
\text { Subcontractor(s) certifying that they have read and understand the NPDES } \\
\text { General Permit rule for construction site stormwater discharges. For Indiana, this } \\
\text { will be } 327 \text { IAC } 15-5 \text { which corresponds to Rule } 5 \text {. This certification should further } \\
\text { state the Contractor has read and understands the SWPPP, plans to implement } \\
\text { the SWWP, and will amend the SWPPP as required by project conditions. } \\
\text { - This form should also make the Contractor(s) and Subcontractor(s) aware of the } \\
\text { legal ramifications and monetary fines that can be imposed for a construction site } \\
\text { stormwater discharge violation. It should be the Contractor's responsibility to pay } \\
\text { any such fines that may results from their erosion and sediment control violations. } \\
\text { It should be the Contractor(s) responsibility to obtain this certification from their } \\
\text { Subcontractor(s). }\end{array}$ \\
\hline Future Document & NOI Guidance for Utility Relocation with INDOT Right-of-Way \\
\hline $\begin{array}{l}\text { Description and } \\
\text { Reason }\end{array}$ & $\begin{array}{l}\text { - When utility relocation or clearing and grubbing for utility relocation is being } \\
\text { completed as part of an INDOT project, a Rule } 5 \text { permit NOI will be required when } \\
\text { the overall disturbed area of the project is greater than } 1 \text { acre. This document } \\
\text { should present some sequencing considerations for the utility relocation process as } \\
\text { they relate to erosion and sediment control. }\end{array}$ \\
\hline
\end{tabular}




\begin{tabular}{|c|c|}
\hline Future Document & INDOT Vegetation Establishment Manual with Indiana Native Species \\
\hline $\begin{array}{l}\text { Description and } \\
\text { Reason }\end{array}$ & $\begin{array}{l}\text { - A vegetation establishment guide that promotes the use of species native to } \\
\text { Indiana should be developed. This information is particularly important in wetland } \\
\text { planting and duneland areas where the spread of invasive species is a significant } \\
\text { concern. Seed mixtures should also be reviewed as they relate to soil types } \\
\text { common to the State of Indiana (ex. seed mixtures for sandy areas). } \\
\text { - As previously discussed, current INDOT seed mixtures and planting } \\
\text { recommendations should be reviewed. The use of invasive and noxious species } \\
\text { should be restricted only to situations where it can be shown that alternative native } \\
\text { vegetation types will not thrive. } \\
\text { A good reference for native species is the Roadside Use of Native Plants published } \\
\text { by the Federal highway Association. This document is available (as of November } \\
\text { 14, 2005) at http://www.fhwa.dot.gov/environment/handbook.htm } \\
\text { Another useful reference is the 2003 Seeding Manual from the Minnesota } \\
\text { Department of Transportation Office of Environmental Services Erosion Control } \\
\text { Unit. The format of this document is user friendly and well organized. If used as a } \\
\text { reference or seeding guide, the seed mixes suggested in this publication should be } \\
\text { cross referenced and verified as applicable to Indiana conditions. This document } \\
\text { is available (as of November } 14,2005 \text { ) at: } \\
\text { http://www.dot.state.mn.us/environment/pdf files/SeedingManual2003.pdf }\end{array}$ \\
\hline
\end{tabular}

\begin{tabular}{|c|c|}
\hline Future Document & Erosion and Sediment Control Inspector Certification Program \\
\hline $\begin{array}{l}\text { Description and } \\
\text { Reason }\end{array}$ & $\begin{array}{l}\text { - Similar to the other Certified Technician Program Training Manuals, a training } \\
\text { program for erosion and sediment control inspection should be developed for } \\
\text { INDOT employees and field personnel. } \\
\text { - Training information contained in this manual should include: } \\
\text { - Introduction to Stormwater Pollution Prevention } \\
\text { - Background Regulations - NPDES } \\
\text { - Stormwater Pollution Prevention Plan (SWPPP) Basics } \\
\text { - What is a SWPPP } \\
\text { - Amending a SWPPP } \\
\text { - Notice of Intent (NOI) } \\
\text { - Notice of Termination (NOT) } \\
\text { - Construction Phase BMPs - Erosion and Sediment Control } \\
\text { - BMP of BMPs } \\
\text { - BMP Maintenance } \\
\text { - BMP Documentation } \\
\text { - Common Deficiencies } \\
\text { Control Post-Construction Phase BMPs - Long Term Stormwater Pollution } \\
\text { - Types of BMPs } \\
\text { - BMP Inspection } \\
\text { - BMP Maintenance } \\
\text { - BMP Documentation } \\
\text { - Common Deficiencies }\end{array}$ \\
\hline
\end{tabular}




\begin{tabular}{|l|l|}
\hline Future Document & SWPPP Preparation and Submittal Policy \\
\hline & $\begin{array}{l}\text { INDOT should establish a policy of who may prepare and submit or modify an } \\
\text { approved SWPPP. INDOT may wish to limit this to Professional Engineers } \\
\text { registered in the State of Indiana. In this case, the SWPPP should be stamped } \\
\text { Description and } \\
\text { Reason }\end{array} \quad \begin{array}{l}\text { Professional in Erosion and Sediment Control (CPESC) and/or Certified } \\
\text { Professional in Stormwater Quality (CPSWQ), sponsored by the International } \\
\text { Erosion Control Association. }\end{array}$ \\
\hline
\end{tabular}

